\title{
ISSN 2302-8734
}

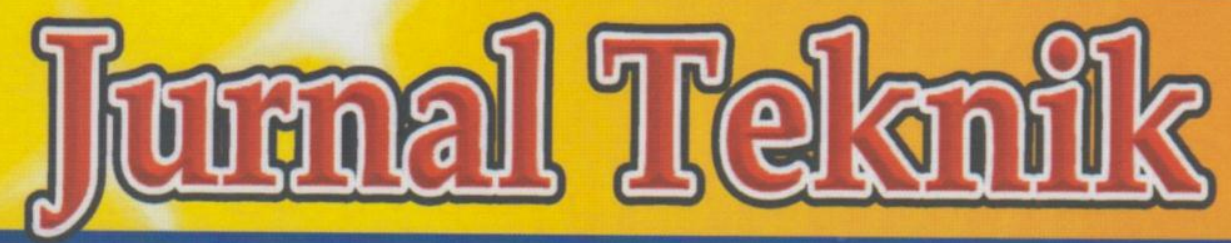

TEKNIK INFORMATIKA - TEKNIK MESIN - TEKNIK SIPIL - TEKNIK ELEKTRO - TEKNIK INDUSTRI

\section{Jurnal Teknik Vol. 1. No. 2 Desember 2012}

ERENCANAAN BETON MUTU TINGGI (KUAT TEKAN BESAR) DENGAN BAHAN TAMBAHAN

Almufid

ANALISIS JUMLAH KANBAN PADA PROSES PRODUKSI SUPPORT ASSY BRAKE PEDAL PART NO. XXXX-XXXX DI DEPARTEMEN WELDING PT. NTC (STUDI KASUS PERUSAHAAN SPARE PART AUTOMOTIVE)

Henri Ponda, Ramdhan Rusmanto

PERANCANGAN APLIKASI OP-AMP DENGAN SOFTWARE GUI MATLAB

Triyono

STUDI EKSPERIMENTAL PENGUJIAN KEKASARAN PERMUKAAN DAN KEAKURASIAN DIMENSI PADA PROSES DRY MACHINING BAJA AISI 01

Riki Candra Putra

SISTEM PENGENDALI KONVEYOR BELT PADA PT. XYZ TANGERANG Sumardi Sadi

ANALISA PENGENDALIAN KUALITAS RESIN ABC MENGGUNAKAN SIX SIGMA DI PT. PARDIC JAYA CHEMICALS

Tri Widodo, Hari Priyadi

ANALISA DAN PERANCANGAN SISTEM PARKIR PADA PT. KMK GLOBAL SPORTS Irfan Nasrullah, Febri Lia Yuliana

ANALISA DAYA POTONG PADA MESIN POTONG GRAPHITE PACKING Joko Hardono

PROTOTYPE SISTEM INFORMASI KINERJA PEGAWAI APARATUR PEMERINTAHAN PADA KANTOR KECAMATAN SUKADIRI KABUPATEN TANGERANG Mahpud, Syamsul Bahri

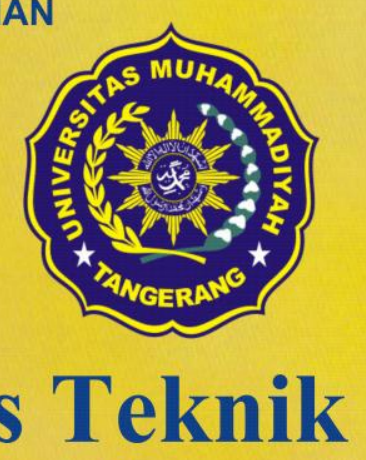

Universitas Muhammadiyah Tangerang 


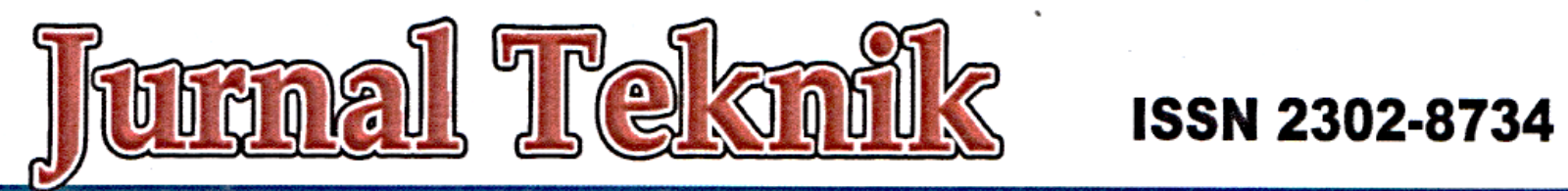

TEKNIK INFORMATIKA-TEKNIK MESIN - TEKNIK SIPIL - TEKNIK ELEKTRO-TEKNIK INDUSTRI

\section{Susunan Redaksi Jurnal Teknik Fakultas Teknik - Universitas Muhammadiyah Tangerang}

Pelindung

Penanggung Jawab

Pembina Redaksi

Pimpinan Redaksi

Redaktur Pelaksana

Dewan Redaksi

Mitra Bestari
: H. Achmad Badawi, S.Pd., SE., MM. (Rektor UMT)

: Ir. Saiful Haq (Dekan Teknik)

: 1. Rohmat Taufik, ST., M.Kom.

2. Drs. H. Syamsul Bahri, MSi.

: Drs. Ir. Sumardi Sadi, MT.

: Mahpud, M.Kom

: 1. M. Jonni, M.Kom.

2. Vienka Rahmanita, MT.

3. Ir. Bayu Purnomo

4. Elfa Fitria, S.Kom, M.Eng.

5. Bambang Suhardi, W, ST, MT.

6. Yafid Efendi, ST, MT.

: 1. Prof. Dr. Aris Gumilar

2. Dr. Ir. Doddy Hermiyono, DEA.

3. Nur Fajar Yanta, MSc.

Alamat :

Jl. Perintis Kemerdekaan I No. 33 Cikokol Tangerang 5537198

Telp. : 02151374916 


\section{DAFTAR ISI}

1. PERENCANAAN BETON MUTU TINGGI (KUAT TEKAN BESAR) DENGAN BAHAN TAMBAHAN - 1

Almufid

2. ANALISIS JUMLAH KANBAN PADA PROSES PRODUKSI SUPPORT ASSY BRAKE PEDAL PART NO. XXXX-XXXXX DI DEPARTEMEN WELDING PT. NTC (STUDI KASUS PERUSAHAAN SPARE PART AUTOMOTIVE) - 8

Henri Ponda, Ramdhan Rusmanto

3. PERANCANGAN APLIKASI OP-AMP DENGAN SOFTWARE GUI MATLAB - 16 Triyono

4. STUDI EKSPERIMENTAL PENGUJIAN KEKASARAN PERMUKAAN DAN KEAKURASIAN DIMENSI PADA PROSES DRY MACHINING BAJA AISI 01 - 26

Riki Candra Putra

5. SISTEM PENGENDALI KONVEYOR BELT PADA PT. XYZ TANGERANG - 35 Sumardi Sadi

6. ANALISA PENGENDALIAN KUALITAS RESIN ABC MENGGUNAKAN SIX SIGMA DI PT. PARDIC JAYA CHEMICALS - 51

Tri Widodo, Hari Priyadi

7. ANALISA DAN PERANCANGAN SISTEM PARKIR PADA PT. KMK GLOBAL SPORTS - 63 Irfan Nasrullah, Febri Lia Yuliana

8. ANALISA DAYA POTONG PADA MESIN POTONG GRAPHITE PACKING - 80 Joko Hardono

9. PROTOTYPE SISTEM INFORMASI KINERJA PEGAWAI APARATUR PEMERINTAHAN PADA KANTOR KECAMATAN SUKADIRI KABUPATEN TANGERANG - 88 Mahpud, Syamsul Bahri 


\section{Sambutan Dekan \\ Fakultas Teknik \\ Universitas Muhammadiyah Tangerang}

Puji Syukur kehadirat Allah Swt. karena berkat karunia dan ijin-Nyalah Tim penyusun Jurnal Teknik Fakultas Teknik Universitas Muhammadiyah Tangerang dapat menyelesaikan tugasnya tepat sesuai dengan waktu ditetapkan.

Saya menyambut baik diterbitkannya Jurnal Teknik Vol. 1 No. 2 Desember 2012, terbitnya jurnal ini, merupakan respon atas terbitnya Peraturan Menteri Pendidikan Nasional No. 17 Tahun 2010 tentang Pencegahan dan Penanggulangan Plagiat di Perguruan Tinggi; Surat Dirjen Dikti Nomor 2050/E/T/2011 tentang kebijakan unggah karya ilmiah dan jurnal; Surat Edaran Dirjen Dikti Nomor 152/E/T/2012 tertanggal 27 Januari 2012 perihal publikasi karya ilmiah yang antara lain menyebutkan untuk lulusan program sarjana terhitung mulai kelulusan setelah 2012 harus menghasilkan makalah yang terbit pada jurnal ilmiah.

Terbitnya Jurnal ini juga diharapkan dapat mendukung komitmen dalam menunjang peningkatan kemampuan para dosen dan mahasiswa dalam menyusun karya ilmiah yang dilandasi oleh kejujuran dan etika akademik. Perhatian sangat tinggi yang telah diberikan rektor Universitas Muhammadiyah Tangerang khususnya mengenai plagiarism dan cara menghindarinya, diharapkan mampu memacu semangat dan motivasi para pengelola jurnal, para dosen dan mahasiswa dalam menyusun karya ilmiah yang semakin berkualitas.

Saya mengucapkan banyak terimakasih kepada para penulis, para pembahas yang memungkinkan jurnal ini dapat diterbitkan, dengan harapan dapat dimanfaatkan seoptimal mungkin dalam peningkatan kualitas karya ilmiah.

Dekan Fakultas Teknik

Universitas Muhammadiyah Tangerang,

Ir. Saiful Haq, M.Si 


\section{Pengantar Redaksi \\ Jurnal Teknik}

Universitas Muhammadiyah Tangerang

Puji dan Syukur Alhamdulillah kami panjatkan kehadapan Allah Swt. atas karunia dan lindungan-Nya sehingga Jurnal Teknik Vol. 1 No. 2 Bulan Desember 2012 dapat diterbitkan.

Menghasilkan karya ilmiah merupakan sebuah tuntutan perguruan tinggi di seluruh dunia. Tri Dharma Perguruan Tinggi yaitu darma pendidikan, darma penelitian, dan darma pengabdian kepada masyarakat mendorong lahirnya dinamika intelektual diantaranya menghasilkan karya-karya ilmiah. Penerbitan Jurnal Teknik ini dimaksudkan sebagai media dokumentasi dan informasi ilmiah yang sekiranya dapat membantu para dosen, staf dan mahasiswa dalam menginformasikan atau mempublikasikan hasil penelitian, opini, tulisan dan kajian ilmiah lainnya kepada berbagai komunitas ilmiah.

Buku Jurnal yang sedang Anda pegang ini menerbitkan 16 artikel yang mencakup bidang teknik sebagaimana yang tertulis dalam daftar isi dan terdokumentasi nama dan judul-judul artikel dalam kulit cover Jurnal Teknik Vol. 3 No. 2 bulan Januari 2015 dengan jumlah halaman 1-155 halaman.

Jurnal Teknik ini tentu masih banyak kekurangan dan masih jauh dari harapan, namun demikian tim redaksi berusaha untuk ke depannya menjadi lebih baik dengan dukungan kontribusi dari semua pihak. Harapan Jurnal Teknik akan berkembang menjadi media komunikasi intelektual yang berkualitas, aktual dan faktual sesuai dengan dinamika di lingkungan Universitas Muhammadiyah Tangerang.

Tak lupa pada kesempatan ini kami mengundang pembaca untuk mengirimkan naskah ringkasan penelitiannya ke redaksi kami. Kami sangat berterimakasih kepada semua pihak yang telah membantu penerbitan Jurnal Teknik ini semoga buku yang sedang Anda baca ini dapat bermanfaat.

Pimpinan Redaksi Jurnal Teknik Universitas Muhammadiyah Tangerang,

Drs. Ir. Sumardi Sadi, MT 


\title{
PERENCANAAN BETON MUTU TINGGI (KUAT TEKAN BESAR) DENGAN BAHAN TAMBAHAN
}

\author{
Almufid \\ Dosen Teknik Sipil \\ Fakultas Teknik \\ Universitas Muhammadiyah Tangerang \\ E-mil:almufid_st@yahoo.com
}

\begin{abstract}
ABSTRAK
Beton adalah element yang digunakan sebagai struktur dalam konstruksi teknik sipil yang dapat dimanfaatkan untuk banyak hal. Dalam teknik sipil struktur beton digunakan untuk bangunan pondasi, kolom, balok, plat/plat cangkang. Beton dikategorikan mempunyai mutu tinggi jika kuat tekannya $30 \mathrm{Mpa}$. Pada tahun 19601970, kriterianya naik menjadi $40 \mathrm{Mpa}$. Saat ini beton dikatakan sebagai beton mutu tinggi jika kuat tekannya diatas $50 \mathrm{Mpa}$ dan diatas $80 \mathrm{Mpa}$ adalah beton dengan mutu sangat tinggi (supartono, 1998) pada tahun 1980an beton mutu tinggi banyak digunakan untuk bangunan tingkat, terutama untuk element struktur kolom.

Didalam beton, agregat mempunyai peran penting yaitu $60 \%-80 \%$, dari volume beton, dari segi ekonomis harga agregat lebih rendah dibandingkan dengan PC, namun agregat terlalu banyak menyebabkan pasta cemen tidak mampu menyelimuti dan mengisi atau merekatkan seluruh permukiman butiran agregat.

Beberapa cara meningkatkan kinerja beton menjadi beton bermutu tinggi dan berkinerja tinggi adalah Mengurangi porositas beton dengan cara mengurangi air dalam adukan beton, Menambahkan aditif mineral seperti silicafume atau abu terbang, Menambahkan serat (beton berserat), Beton dengan pemadatan mandiri (self compacting concrete)
\end{abstract}

Kata Kunci: Beton, Kuat Tekan, Beton bermutu Tinggi

\section{PENDAHULUAN}

\subsection{Latar Belakang Masalah}

Banyak parameter yang mempengaruhi kekuatan tekan beton, Kekuatan tekan adalah kapasitas dari suatu bahan atau struktur dalam menahan beban yang akan mengurangi ukurannya. Kekuatan tekan dapat diukur dengan memasukkannya ke dalam kurva tegangan-regangan dari data yang didapatkan dari mesin uji. Diantaranya adalah kualitaas bahan-bahan penyusunnya, rasio air semen yang rendah dan kepadatan yang tinggi. Kekuatan tekan akhir sebuah beton keras akan ditentukan oleh Agregat yang terlemah. Agregat utama beton padat terdiri dari agregat kasar yang biasanya berbentuk batu dan matriks semen-pasir. Struktur beton bertulang bangunan atau gedung biasanya menggunakan mutu beton yang berbeda-beda, disesuaikan dengan perencanaan struktur masing-masing. Semakin berat beban (gaya normal, gaya lintang, momen) yang akan dipikul oleh suatu beton bertulang, maka sebaiknya menggunakan mutu beton yang semakin tinggi juga. Sehingga dibutuhkan beberapa faktor yang akan mempengaruhi agar kuat tekan beton bermutu tinggi, ada empat bagian utama yang mempengaruhi mutu dari kekuatan beton tersebut, yaitu: 
1. Penyerapan bahan yang memenuhi syarat.

2. Proses pencampuran agregat beton dengan pasta semen.

3. Proses pengecoran saat di lapangan. 4). Serta proses pengawetan beton yang

\subsection{Pengunaan Agregat}

Dalam pemakaian agregat pada pemakaiannya digunakan dengan komposisi tertentu agar mendapatkan suatu campuran beton yang ekonomis dan mempunyai nilai Kuat Tekan yang tinggi (Beton Mutu Tinggi).

\subsection{Cara Meningkatkan Beton Tinggi}

Beberapa cara meningkatkan kinerja beton menjadi beton bermutu tinggi dan berkinerja tinggi.

1. Mengurangi porositas beton dengan cara mengurangi air dalam adukan beton,

2. Menambahkan aditif mineral seperti silicafume atau abu terbang,

3. Menambahkan serat (beton berserat),

4. Beton dengan pemadatan mandiri (self compacting concrete).

\section{PEMBAHASAN BETON TINGGI}

\subsection{Material Beton Tinggi}

Pengunaan bahan yang memenuhi syarat adalah merupakan salah satu factor yang dapat mempengaruhi dalam pembuatan beton yang bermutu tinggi. Disini yang mempengruhi mutu suatu beton dapat dilihat dari beberapa factor berikut:

\section{a. Agregat Halus}

Agregat yang semua butirannya lolos ayakan $4.8 \mathrm{~mm}(\mathrm{SII}, 0052,1980)$ atau $4.75 \mathrm{~mm}$ (ASTM C33, 1982) atau $5.0 \mathrm{~mm}$ (BS, 812, 1976).

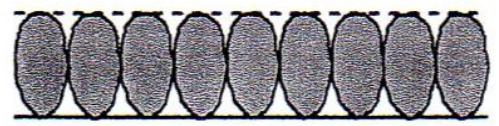

Gambar 1. Agregat Halus

\section{b. Agregat Kasar}

Agregat yang semua butirnya tertinggal diayakan $4.8 \mathrm{~mm}(\mathrm{SII}, 0052,1980)$ atau
$4.74 \mathrm{~mm}$ (ASTM C33,1982) atau 5,0 $\mathrm{mm}$ (BS,812,1976).

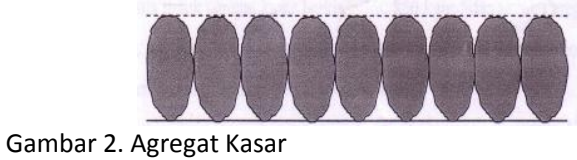

Pemerisaan Agregat kasar (Koral/split)

- Gradasi (sieve analysis)

- $\quad$ Spesific grafity dan penyerapan air

- $\quad$ Pengujian kekeran (los Angeles mechine)

- $\quad$ Berat isi agregat kasar (unit weight)

\section{c. Factor Semen (PC)}

Semen yang paling baik digunakan dalam pembuatan beton mutu tinggi adalah semen tipe II, yaitu semen Portland yang dalam penggunaannya mempunyai ketahanan terhadap sulfat dan kalor hidrasinya lebih kecil dari jenis satu. Semen ini biasanya digunakan untuk pekerjaan beton yang bervolume besar. Kandungan C3S kurang dari $50 \%$ dan kandungan C3A kurang dari 8\%. Jika kadar semen dinaikkan, maka kekuatan dan durabilitas beton juga akan meningkat. Semen (bersama dengan air) akan membentuk pasta yang akan mengikat agregat mulai dari yang paling besar (kasar) sampai yang paling halus.

\section{d. Faktor Air Semen (FAS)}

Dapat dicari berdasar jenis semen yang dipakai dan kuat tekan rata-rata silinder beton yang direncanakan pada umur 28 hari, ditetapkan nilai fas dengan gb. 7.8. Faktor air semen yang rendah, merupakan faktor yang paling menentukan dalam menghasilkan beton mutu tinggi, dengan tujuan untuk mengurangi seminimal mungkin porositas beton yang dihasilkan. Dengan demikian semakin besar volume faktor air-semen (fas) semakin rendah kuat tekan betonnya. Berikut ini beberapa persyaratan air menurut SKSNI, ACl, dan British Standard dan SNI 2012

Persyaratan air menurut $\mathrm{ACl} 318-83$, SNI 2012:

1. Bersih. 
2. Tidak mengandung minyak, alkali, garam, bahan organik yang berbahaya terhadap beton.

3. Untuk beton pratekan, atau beton yang dekat dengan alumunium, maka air tidak boleh mengandung $\mathrm{Cl}$.

4. Bukan air minum tidak boleh dipakai untuk campuran beton, kecuali uji adukan standar seperti tersebut dalam ASTM C109. kuat tekan umur 7 dan 28 hari tidak kurang dari $90 \%$ dibanding kuat tekan kubus yang dibuat dengan air minum.

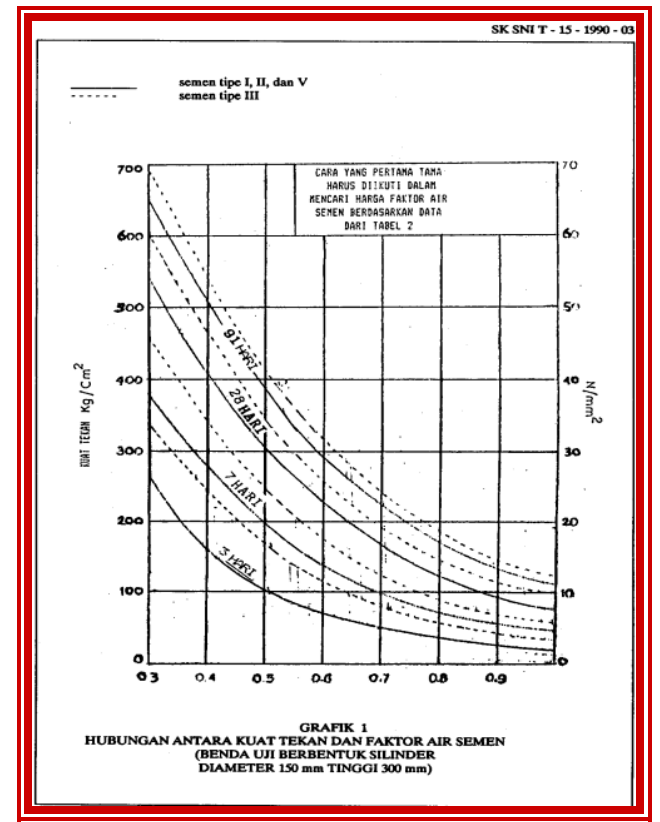

Gambar 3. Faktor Air Semen / Water of Contens

Terhadap Kuat Tekan Beton

\section{e. Mikrosilika (Silica fume)}

Mikrosilika (silicafume), yang merupakan produk sampingan dari suatu proses industri Silicon Metal, adalah merupakan bahan tambahan (aditif) yang sangat baik dan berdayaguna tinggi untuk campuran beton, dalam tujuan menghasilkan beton berkinerja tinggi.

Bila mikrosilika, yang bersifat pozzolan dengan ukuran butiran yang sangat halus, dan pada umumnya mengandung lebih dari $80 \% \mathrm{SiO}_{2}$ aktif, ditambahkan pada campuran beton, ternyata akan dapat bereaksi dengan
$\mathrm{Ca}(\mathrm{OH})_{2}$ yang dihasilkan dari proses hidrasi $\mathrm{C}_{3} \mathrm{~S}$ dan $\mathrm{C}_{2} \mathrm{~S}$, untuk menghasilkan gel $\mathrm{CSH}$ yang baru (gel CSH-2).

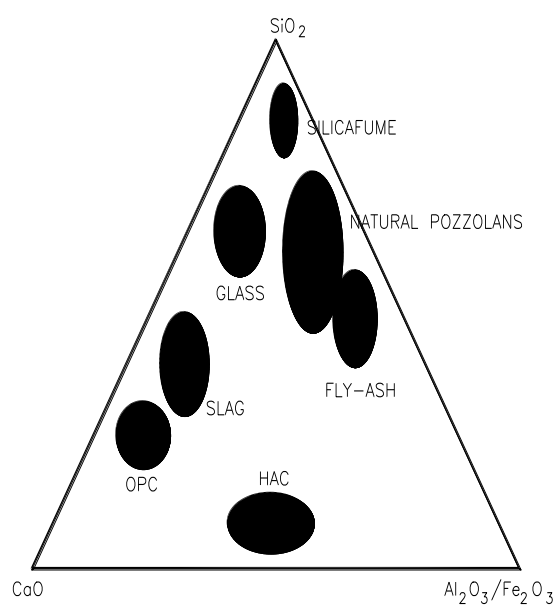

Gambar 4. Bentuk Silikafume

$2\left(3 \mathrm{CaO} . \mathrm{SiO}_{2}\right)+6 \mathrm{H}_{2} \mathrm{O} 3 \mathrm{CaO} .2 \mathrm{SiO}_{2} \cdot 3 \mathrm{H}_{2} \mathrm{O}$ (gel $\mathrm{CSH}-1)+3 \mathrm{Ca}(\mathrm{OH})_{2} \mathrm{Ca}(\mathrm{OH})_{2}+\mathrm{SiO}_{2}(\mathrm{SF})+\mathrm{H}_{2} \mathrm{O}$ gel CSH-2

Jika kadar $\mathrm{SiO}_{2}$ di dalam mikrosilika sangat tinggi sehingga masih terdapat kandungan $\mathrm{SiO}_{2}$ dalam mikrosilika yang tidak terpakai dan berlebih pada reaksi primer $\mathrm{SiO}_{2}$, maka kelebihan $\mathrm{SiO}_{2}$ masih bisa bereaksi dengan $\mathrm{CSH}-2$, untuk menghasilkan gel CSH-3 yang lebih padat sehingga pasta semen akan semakin kuat, dan yang akan meningkatkan juga daya lekat pasta semen dengan agregat.

\subsection{Manfaat Penambahan Silikafume pa- da kinerja Beton}

Secara umum, berdasarkan hasil-hasil penelitian yang dilakukan, penggunaan mikrosilika sebagai aditif mineral akan dapat memperbaiki banyak aspek dalam kinerja beton, antara lain:

1. meningkatkan mutu beton,

2. meningkatkan kemudahan pemompaan beton walaupun kemungkinan nilai slump yang didapat lebih kecil,

3. meningkatkan kekedapan beton terhadap penetrasi air meningkatkan ketahanan beton terhadap sulfat dan klorida 
4. mengurangi susut dan rangkak beton

5. meningkatkan keawetan (durability) beton.

\section{METODE PENELITIAN}

Untuk menghasilkan beton bermutu tinggi maka dibutuhkan prosedur yang benar dan cermat pada keseluruhan proses produksi beton yang meliputi:

\subsection{Pengujian agregat}

1. Agregat halus untuk beton dapat berupa pasir alam sebagai hasil desintergris alami dari batu-batuan atau berupa pasir buatan yang dihasilkan oleh alat pemecahan batu.

2. Agregat halus harus terdiri dari butirbutir yang tajam dan keras. Bersifat kekal artinya tidak pecah/hancur oleh pengaruh cuaca-terik matahari dari hujan.

3. Tidak boleh mengandung Lumpur dari 5\% (ditentukan terhadap berat kering) lumpur adalah bagian-bagian yang dapat melalui ayakan $\varnothing 0.063 \mathrm{~mm}$. Apabila kadar lumpur melampaui 5\% maka agregat halus dicuci.

4. Tidak boleh mengandung bahan- bahan organis terlalu banyak yang dapat dibuktikan dengan percobaan AbramsHarder. dengan larutan 3\% NaOH-130 $\mathrm{cc}+$ pasir $200 \mathrm{cc}$, dikocok dan didiamkan 24 jam. Jika warna cairan bening muda berati tidak ada bahan organis baik. Warna Kuning Tua pasir mengandung kotoran organis tidak baik, apabila dipakai harus dicuci berwarna merah kuning-coklat tua jelek, maka pasir tdk bisa dipakai.

5. Agregat halus terdiri dari butir-butir yang beraneka ragam besarnya. Dapat diselidiki dengan analisa saringan (sieve analasyis) dengan susunan ayakan sbb;

1) sisa di atas ayakan $\varnothing 4 \mathrm{~mm}$, harus minimum $2 \%$ berat sisa di atas ayakan $\varnothing 1 \mathrm{~mm}$, harus minimum $10 \%$ berat sisa di atas ayakan $\varnothing 0.25 \mathrm{~mm}$, harus minimum $80 \%$ berat dan $95 \%$ berat.

2) Apabila tidak tersedia susunan ayakan seperti diatas, susunan ayakan lain dapat dipakai asal mempunyai ukuran lubang yang mendekati ukuran diatas.

3) Pasir laut tidak dapat dipakai sebagai agregat halus untuk semua mutu beton, kecuali dengan petunjuk-petunjuk dari lembaga pemeriksaan bahan. (garam/ $\mathrm{NaCl}$ ).

\section{2 Semen (PC)}

Semen Portland (PC) umum pada berbagai tipe (yang memenuhi spesifikasi standar ASTM C 150) dapat digunakan untuk memperoleh campuran beton dengan kekuatan tekan sampai dengan $50 \mathrm{Mpa}$. Untuk mendapatkan kuat tekan yang lebih tinggi saat mempertahankan workability yang baik, sangat perlu untuk menggunakan admixture yang dikombinasikan dengan semen. Pada kasus tersebut, kompabilitas semen-admixture menjadi sebuah hal yang penting.

Feret formula:

$$
R=K\left[\frac{1}{1+3 w / c}\right]^{2}
$$

Abrams formula:

$$
R=\frac{A}{B^{w / c}}
$$

$$
\log R=\log A-(w / c) \log B
$$

$\log R=\log A-(1,5 w / c) \log B$

$\log \mathrm{R}=\log \mathrm{A}-(w / c) \log B w$

Bolomev formula:

$$
R=K_{B}\left[\frac{1}{w / c}-0.50\right]
$$



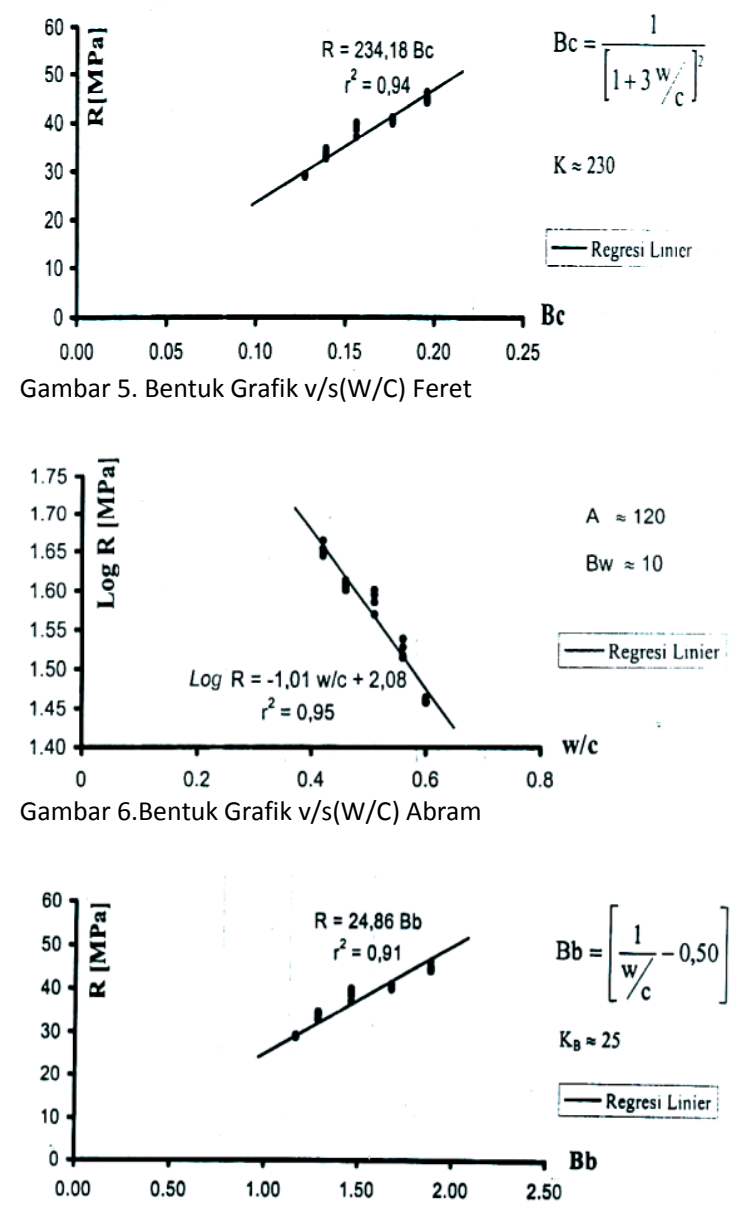

Gambar7.Bentuk Grafik v/s(W/C) Bolomay

Pengalaman telah memperlihatkan bahwa, dengan penggunaan tipe superplasticizer naphthalene sulfonate atau melamine sulfonate, semen portland dengan kadar $\mathrm{C}_{3} \mathrm{~A}$ dan alkali yang rendah umumnya menghasilkan campuran beton yang memperlihatkan hilangnya slump tinggi sejalan dengan waktu. Situasi ini telah berubah karena telah dilaporkan bahwa polyacrylate copolymer, sebuah generasi baru superplasticizer, tidak menyebabkan kehilangan slum yang berlebihan pada kebanyakan jenis semen Portland maupun semen portland campuran.

\subsection{Silicafume}

Dalam teknologi beton, Silica Fume

(SF) digunakan sebagai pengganti sebagian dari semen atau bahan tambahan pada saat sifat-sifat khusus beton dibutuhkan, seperti penempatan mudah, kekuatan tinggi, permeabilitas rendah, durabilitas tinggi, dan lain sebagainya. Silica fume merupakan hasil sampingan dari produk logam silikon atau alloy ferosilikon. Menurut standar "Spesification for Silica Fume faor Use in Hydraulic Cement Concrete and Mortal" (ASTM. C.1240, 1995: 637-642), silica fume adalah material pozzolan yang halus, dimana komposisi silika lebih banyak dihasilkan dari tanur tinggi atau sisa produksi silikon atau alloy besi silikon (dikenal sebagai gabungan antara micro silica dengan silica fume), Penggunaan silica fume dalam campuran beton dimaksudkan untuk menghasilkan beton dengan kekuatan tekan yang tinggi. Beton dengan kekuatan tinggi digunakan, misalnya, untuk kolom struktur atau dinding geser, pre-cast atau beton pra-tegang dan beberapa keperluan lain. Kriteria kekuatan beton berkinerja tinggi saat ini sekitar 50-70 Mpa untuk umur 28 hari. Penggunaan silica fume berkisar 0$30 \%$ untuk memperbaiki karakteristik kekuatan keawetan beton dengan faktor air semen sebesar 0,34 dan 0,28 dengan atau tanpa superplastisizer dannilai slump $50 \mathrm{~mm}$ (Yogerdran, et al, 1987: 124-129).

Keuntungan-keuntungan penggunaan silica fume dan superplatisticizer pada campuran beton menurut beberapa hasil penelitian terdahulu antara lain seperti kekuatan tekan hancurnya lebih tinggi, kekuatan tarik lebih tinggi, rangkaknya lebih kecil, regangan yang terjadi kecil, susutnya kecil, modulus elastisitasnya tinggi, ketahanan terhadap serangan klorida tinggi, ketahanan terhadap keausan tinggi dan permeabilitas lebih kecil (220). Dalam hal ketahanan terhadap serangan klorida tinggi, menurut Sorensen (Rachee dan Kumar, 1989), mengatakan bahwa dengan berkurangnya permeabilitas beton, berarti juga akan berkurangnya penetrasi serangan kimia. 
Kendala-kendala yang ada dalam penggunaan silica fume antara lain seperti, handling/pelaksanaan, bahaya kesehatan kerja, air entrainment, plastic shringkage, dan quality control. SF merupakan bahan sangat lembut dan mudah sekali terbang kena angin, maka perlu diperhatikan dalam pelaksanaan loading, penangkutan, peyimpanan dan pencampuran. Sehubungan dengan kesehatan kerja, karena SF sangat halus, kemungkinan penghisap SF oleh pekerja akan terjadi, oleh karena itu pekerja harus dilengkapi dengan lat pelindung pernafasan.

\subsection{Pengadukan}

Secara umum, pengadukan dengan mesin harus dilakukan menggunakan mesinmesin yang telah di setujui penggunaannya (PB,1989:27) Mesin pengaduk harus di putar sesuai dengan kecepatan yang rekomendasikan oleh pabrick pembuatnya.

Setelah pencampuran seluruh badan dalam batchin, harus dilakukan pengadukan kembali minimal selam 1.5 menit, kecuali bila dapat di buktikan bahwa pengadukan yang lebih pendek mampu memberikan hasil yang lebih memuaskan dan memenuhi pengujian keseragaman pengadukan yang ditetapkan dalam ASTM C.94. Ketentuan mengenai waktu pengadukan dapat di lihat pada. Waktu pengadukan Minimal kapasitas dari mixer (m3) ASTM C.94 dan ACl 318

$\begin{array}{ll}0.8-3.1 & 1 \text { Menit } \\ 3.8-4.6 & 2 \text { Menit } \\ 7.6 & 3 \text { Menit }\end{array}$

\subsection{Pengangkutan}

Beton diangkut dengan berbagai cara, mulai dari truk readi mix, sampai pompa beton. Sedikitnya ada 3 macam gerakan, yaitu dari pengadukan sampai ke lokasi, dari lokasi kebagian yang dicor secara vertikal maupun horizontal.

Hal-hal yang harus di perhatikan dalam pengangkutan beton dari tempat penyiapan adukan ke tempat pengecoran adalah sbb:
1. Harus dihindari adanya kekurangan bahan yang akan dicor pada proses pengadukan.

2. Pengangkutan adukan beton harus lancar sehingga tidak terjadi perbedaan waktu pengikatan beton yang akan dicor.

3. Adukan beton umumnya sudah harus dicor dalam waktu 1 jam setelah pengadukan dengan air dimulai dan $\max 2$ jam setelah pengadukan

4. Jika jangka waktu pengangkutan yang panjang maka digunakan bahan penghambatan pengitan betom

\section{KESIMPULAN}

Beberapa cara meningkatkan kinerja beton menjadi beton bermutu tinggi dan berkinerja tinggi

1. Mengurangi porositas beton dengan cara mengurangi air dalam adukan beton,

2. Menambahkan aditif mineral seperti silicafume atau abu terbang,

3. Menambahkan serat (beton berserat),

4. Beton dengan pemadatan mandiri (self compacting concrete),

5. Perawatan dengan isolasi permukaan beton.

\section{DAFTAR PUSTAKA}

Anonim, CIP 33 - High Strength Concrete, National Ready Mixed Concrete Association. 2010

Civil Engineering Portal, http://www.engineeringcivil.com/, portal khusus untuk teknik sipil.

Kartini, Wahyu. 2002. "Pengaruh Copper Slag sebagai Cementitius terhadap Kuat Tekan pada beton."

Kosmatka, Steven H., Kerkhoff, Beatrix, dan Panarese, William C., 2003. Design and 
Con-trol of Concrete Mixture. Portland Cement Association, Illionis.

Mehtar, P. Kumar, dan Monteiro, Paulo J.M., 2006. Concrete - Microstructure, Properties and Materials, 3rd edition., McGraw-Hill, New York.

Supartono, FX - Beton Mutu Tinggi, UI - Press 2010 


\title{
ANALISIS JUMLAH KANBAN PADA PROSES PRODUKSI SUPPORT ASSY BRAKE PEDAL PART NO. $X X X X-X X X X$ DI DEPARTEMEN WELDING PT. NTC (STUDI KASUS PERUSAHAAN SPARE PART AUTOMOTIVE)
}

\author{
Henri Ponda ${ }^{1)}$, Ramdhan Rusmanto ${ }^{2)}$ \\ ${ }^{1)}$ Staff Pengajar Program Studi Teknik Industri Universitas Muhammadiyah Tangerang \\ E-mail: henri_ponda@yahoo.com \\ ${ }^{2)}$ Praktisi Industri \\ E-mail:ramdhan_rusmanto@yahoo.com
}

\begin{abstract}
ABSTRAK
Pada saat ini teknologi yang digunakan pada sektor industri terus mengalami perubahan perbaikan dan berkembang dengan cepat. Dengan kemajuan teknologi yang sangat cepat industri-industri di Indonesia menerapkan manajemen produksi yang memegang peranan yang cukup penting adalah sistem produksi, karena sistem produksi merupakan rangkaian gabungan beberapa elemen yang saling menunjang dan berhubungan antara satu dengan yang lain untuk melaksanakan proses produksi dalam suatu perusahaan sehingga lebih efektif dan efisien. Prinsip JIT adalah menghilangkan pemborosan (eliminating waste) dan meningkatkan nilai tambah, yang akhirnya meningkatkan laba dan memperbaiki ROI (return on investment). ROI adalah laba dibagi dengan total asset. Sementara itu Laba adalah pendapatan dikurangi biaya. Jika biaya turun, maka laba naik dan akibatnya ROI naik. Kanban adalah suatu kartu mirip label yang berisi catatan-catatan tentang jumlah dan jenis unit yang diperlukan dan biasanya ditaruh dalam amplop vinil berbentuk empat persegi panjang atau bujur sangkar, yang dikirim pekerja dari suatu proses kepada pekerja pada proses yang terdahulu. Akibatnya, banyak proses dalam pabrik akan saling berkaitan. Jumlah Kanban yang dibutuhkan untuk membantu proses produksi Support Assy Brake Pedal Part No. $x x x x-x x x x$ di Departemen Welding yaitu berjumlah 1 (satu) Kanban.
\end{abstract}

Kata Kunci: Just In Time, Kanban, Waktu Siklus, Waktu Normal, Waktu Baku

\section{PENDAHULUAN}

Pada era globalisasi ini, industri merupakan salah satu sektor yang mengalami kemajuan sangat pesat. Pada saat ini teknologi yang digunakan pada sektor industri terus mengalami perubahan perbaikan dan berkembang dengan cepat. Dengan kemajuan teknologi yang sangat cepat industri-industri di Indonesia menerapkan manajemen produksi yang memegang peranan yang cukup penting adalah sistem produksi, karena sistem produksi merupakan rangkaian ga- bungan beberapa elemen yang saling menunjang dan berhubungan antara satu dengan yang lain untuk melaksanakan proses produksi dalam suatu perusahaan. Banyak industri yang ada di Indonesia saat ini, tetapi peneliti lebih tertarik kepada industri otomotif, khususnya yang menghasilkan komponen-komponen atau part-part mobil. Penulis ingin melihat dari dekat bagaimana suatu proses produksi dan perakitan berjalan di industri otomotif khususnya pada PT. NTC. 
PT. NTC merupakan salah satu perusahan yang menerapkan sistem produksi adaptasi dari perusahaan sejenisnya di Jepang. Sistem produksi yang diterapkan yaitu Sistem Kanban yang merupakan alat untuk mencapai sistem produksi tepat waktu (Just In Time) yang diperkenalkan oleh perusahaan Toyota Motor Corp. Japan. Untuk memenuhi jumlah permintaan pasar akan produk yang dihasilkan dan untuk dapat mengendalikan produksi yang diperlukan pada waktu yang diperlukan dalam setiap proses dibutuhkan perencanaan yang baik dari manajemen produksi berupa penerapan Sistem Kanban. Oleh karena itu aktivitas produksi yang terus ditingkatkan kualitasnya dengan penerapan dan perbaikan dari sistem produksi yang ada harus terus dipahami dan dilaksanakan dengan baik oleh seluruh karyawan dan staff manajemen. Untuk itu dibutuhkan pengetahuan yang cukup mengenai sistem tarik (Sistem Kanban) ini.

\section{PERUMUSAN MASALAH}

Peneliti mencoba menganalisa Sistem Kanban yang berlaku di PT. NTC dengan memfokuskan pada kebutuhan jumlah Kanban. Adapun yang menjadi pokok pemasalahan yaitu, menentukan berapa jumlah Kanban teoritis pada proses perakitan Support Assy Brake Pedal part no. xxxx-xxxx pada departemen welding. Alasan memilih part tersebut dalam perhitungan Kanban karena part tersebut sering diproduksi atau diorder oleh PT. TMMI.

\section{TUJUAN PENELITIAN}

Tujuan dari penelitian ini adalah untuk mengetahui jumlah kanban yang dibutuhkan dalam proses perakitan komponen Support Assy Brake Pedal part no. xxxx-xxxx pada departemen welding. Serta menjadi referensi untuk penelitian-penelitian berikutnya, sehingga dapat mengembangkan teknik kanban.

\section{METODOLOGI PENELITIAN}

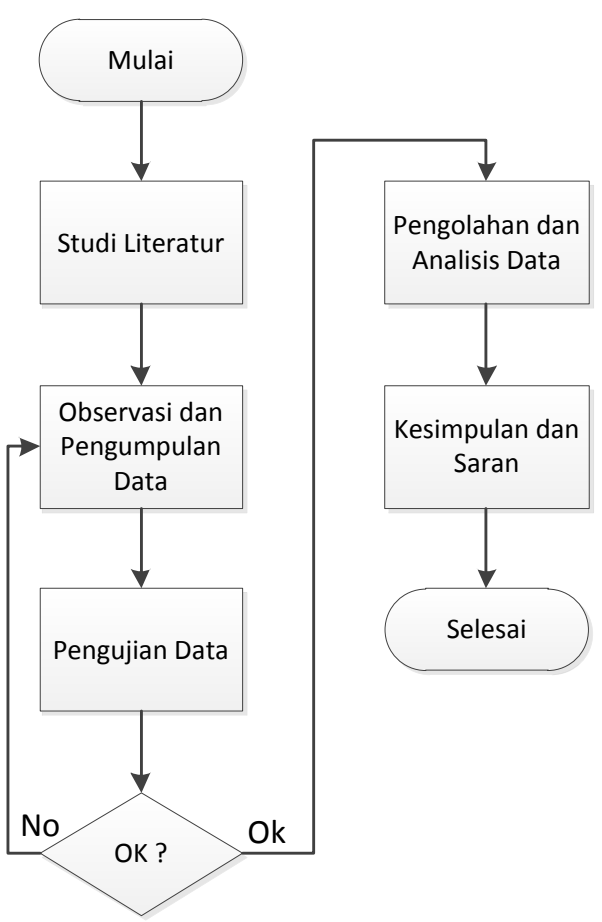

Gambar 1. Alur Metodologi Penelitian

\section{LANDASAN TEORI}

\subsection{Pengertian JIT (Just In Time)}

Just In Time adalah suatu pendekatan yang berusaha menghilangkan semua pemborosan, sesuatu yang tidak menambah nilai, di dalam kegiatan produksi dengan memproduksi berdasarkan atas jumlah barang yang benar-benar diperlukan secara tepat waktu pada saat dibutuhkan. Konsep JIT muncul di Jepang melalui apa yang disebut Kaizen (perbaikan terus menerus). Just In Time (JIT) sendiri bukan istilah Jepang tetapi istilah dari Barat yang mampu melihat fenomena manajemen di Jepang.

Prinsip JIT adalah menghilangkan pemborosan (eliminating waste) dan meningkatkan nilai tambah, yang akhirnya meningkatkan laba dan memperbaiki ROI (return on investment). ROI adalah laba dibagi dengan total asset. Sementara itu Laba adalah pendapatan dikurangi biaya. Jika biaya turun, maka laba naik dan akibatnya ROI naik. 
Sistem JIT dikembangkan pada Toyota Motor Company di Jepang. Meskipun Schonberger (1982) mengindikasikan bahwa JIT mungkin sudah ada 20 tahun lalu pada industri galangan kapal Jepang, namun penerapan JIT modern dipopulerkan pada pertengahan dekade 1970-an pada Toyota oleh Mr. Taiichi Ohno, seorang wakil direktur utama, serta beberapa teman sejawatnya. Konsep JIT kemudian secara nyata ditransfer pertama kali ke Amerika Serikat sekitar tahun 1980 pada Kawasaki's Lincoln, pabrik Nebraska.

Ciri-ciri khas dari JIT adalah: arus barang berdasarkan pull method, kualitas produksi setiap tahap selalu diusahakan baik, ukuran order selalu sedikit, waktu setup pendek, beban kerja yang seimbang, menggunakan komponen dan metode standar, ada hubungan dekat dengan konsumen, sumberdaya manusia yang fleksibel, produksi berfokus pada produk, digunakan automatisasi, dan pemeliharaan dilaksanakan dengan sangat baik.

\subsection{Continuous Improvement Dalam Just In Time}

Dalam JIT biasanya dilengkapi dengan Continous Improvement atau perbaikan yang terus-menerus. Perbaikan ini berupa penemuan sesuatu yang baru untuk memperbaiki yang sudah ada, mencari kelemahan atau penyebab masalah, serta berbagai usaha preventif yang perlu dilakukan. Perbedaan dengan cara yang klasik adalah dalam JIT selalu diusahakan pemecahan masalah yang timbul sekaligus dengan mencari penyebab masalah itu, sehingga setiap persoalan yang timbul selalu diatasi secara tuntas. Pekerjaan ini tidak akan selesai, karena tugas yang dilakukan dalam Continous Improvement adalah selalu mencari masalah yang masih perlu diatasi. Dan ini tidak akan selesai. Kalau dalam cara klasik, masalah diatasi seperlunya aja. Misalnya masalah kekurangan bahan diatasi dengan menyediakan cadangan atau persediaan. Sedang dalam JIT disamping kekurangan itu ditutup, juga dicari penyebabnya yang harus diatasi sehingga dilain waktu tidak akan menimbulkan masalah lagi. Jumlah persediaan barang kalau selalu diadakan studi akan diketahui dengan lebih tepat kebutuhannya.

\subsection{Sistem Kanban}

Sistem Kanban adalah suatu sistem informasi yang secara serasi mengendalikan produksi produk yang diperlukan dalam jumlah yang diperlukan pada waktu diperlukan dalam setiap lantai produksi pada pabrik dan juga diantara perusahaan. Sistem Kanban juga suatu alat untuk mencapai JIT.

Kanban adalah suatu kartu mirip label yang berisi catatan-catatan tentang jumlah dan jenis unit yang diperlukan dan biasanya ditaruh dalam amplop vinil berbentuk empat persegi panjang atau bujur sangkar, yang dikirim pekerja dari suatu proses kepada pekerja pada proses yang terdahulu. Akibatnya, banyak proses dalam pabrik akan saling berkaitan.

Kait-mengaitnya berbagai proses dalam pabrik ini memungkinkan pengendalian yang lebih baik dalam jumlah hal yang diperlukan untuk berbagai produk. Dalam JIT ada yang menggunakan satu kartu, ada pula yang menggunakan dua kartu. Kebanyakan pabrik sekarang menggunakan dua kartu karena lebih mudah dilaksanakan, meskipun kenyataannya akan menyebabkan sistem ini tidak murni zero level inventory, karena ada satu cadangan container barang yang siap dikirimkan. Toyota menggunakan dua kartu. 


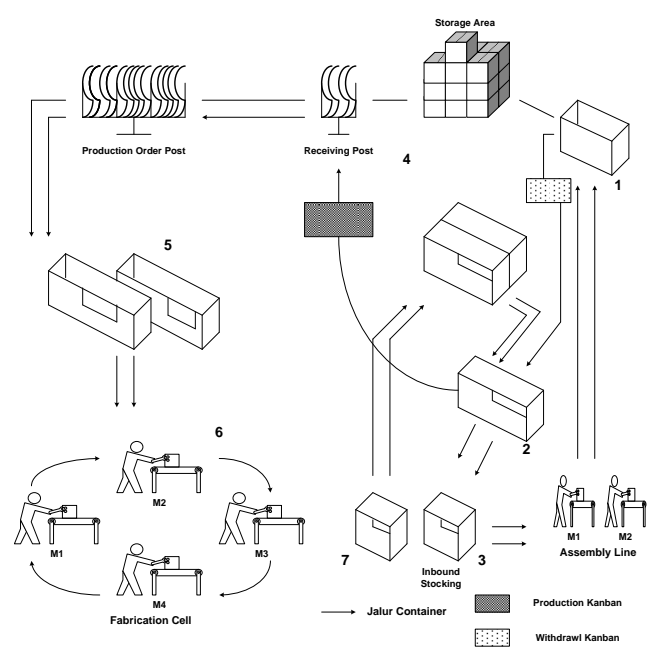

Gambar 2. Sistem Kanban dengan Dua Kartu

Sistem Kanban didukung oleh hal-hal berikut:

1. Pelancaran produksi,

2. Pembakuan pekerjaan,

3. Pengurangan waktu penyiapan,

4. Aktivitas Perbaikan,

5. Rancangan tata ruang mesin, dan

6. Autonomasi (Sistem Pengendali Cacat Secara Otonom).

\subsection{Jenis-jenis Kanban}

Jenis-jenis Kanban yang sering digunakan, yaitu:

1. Kanban Pengambil (Withdrawl Kanban) Suatu Kanban Pengambil menspesifikasikan jenis dan jumlah produk yang harus diambil dari proses terdahulu dari proses berikutnya.

2. Kanban Perintah Produksi (Production Kanban)

Kanban perintah produksi menspesifikasikan jenis dan jumlah produk yang harus dihasilkan proses terdahulu. Kanban perintah produksi sering disebut Kanban dalam pengolahan atau secara sederhana, Kanban Produksi.

3. Kanban Pemasok (Supplier Kanban)

Kanban Pemasok digunakan untuk melaksanakan pengambilan dari jumlah (Pemasok suku cadang atau bahan, juga disebut subkontraktor). Kanban pemasok berisi perintah yang meminta pemasok atau subkontraktor untuk mengirimkan suku cadang.

4. Kanban Pemberi Tanda (Signal Kanban) Kanban pemberi tanda digunakan untuk menerangkan spesifikasi produksi lot dalam setiap proses terdahulu maupun sebelumnya. Kanban pemberi tanda ditempelkan pada suatu kotak dalam lot. Kalau pengambilan mencapai kotak yang ditempeli Kanban ini instruksi produksi harus digerakkan. Dari dua jenis Kanban pemberi tanda ini, yang pertama adalah Kanban Segitiga yang terbuat dari lembaran logam dan cukup berat. Jenis Kanban kedua yaitu Kanban berbentuk segi empat dan disebut Kanban Peminta Bahan.

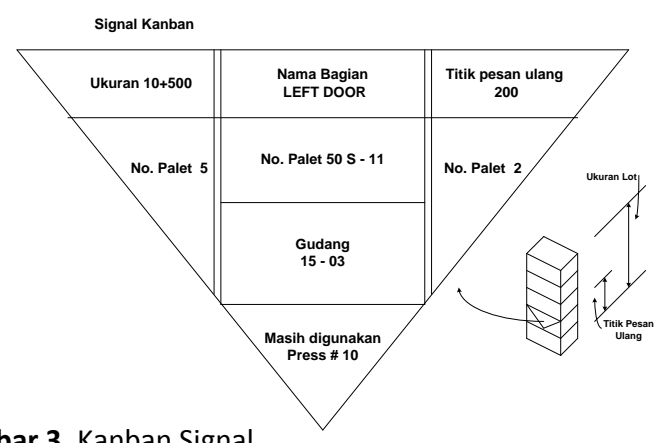

Gambar 3. Kanban Signal

\subsection{Fungsi Sistem Kanban}

Untuk menerapkan konsep Kanban secara efektif, kita perlu memahami fungsinya secara jelas dan mendalam. Fungsi sistem Kanban adalah:

1. Meniadakan Muda, akibat memproduksi secara berlebihan

- Hanya memproduksi sebanyak yang akan diambil dan yang akan digunakan oleh proses berikutnya.

- Memproduksi barang pada saat tidak diperlukan, melebihi jumlah yang diperlukan dan menambah stock, hanya akan menimbulkan bermacammacam kerugian. 
2. Informasi pengambilan dan informasi perintah produksi

- Dengan menggunakan Kanban, informasi mengenai part apa, kapan, berapa banyak diproduksi dan bagaimana pengangkutannya akan mengalir secara jelas sebagai perintah produksi.

3. Alat untuk mengontrol secara visual (Kanban bergerak bersama barang)

- Prinsip pengontrolan visual adalah dapat dilakukan judgement dengan cepat pada saat normal dan abnormal, pada benda dan tempat dll, karena Kanban bergerak bersama barang, maka Kanban mempunyai fungsi yang penting sebagai alat control visual.

4. Alat untuk improvement

- Jika Kanban fluktuasi, dapat dicari penyebab utamanya, kemudian dibuatkan countermeasure improvement-nya.

- Jika jumlah Kanban terlalu banyak, stock akan meningkat, oleh karena itu jumlah Kanban harus dikurangi.

\subsection{Perhitungan Jumlah Kanban}

Persamaan yang dapat digunakan untuk menghitung jumlah Kanban adalah sebagai berikut:

$k=$ rata - rata permintaan sepanjang lead time dan safety stock

$k=\frac{d(\bar{w}+\bar{p})(1+\alpha)}{c}$

keterangan:

k : jumlah production kanban/withdrawl kanban untuk suatu part.

d : rata-rata permintaan harian untuk part (dalam unit).

w : rata-rata waktu tunggu sepanjang proses produksi ditambah waktu penanganan bahan per kontainer (dalam fraksi satu hari).

p : rata-rata waktu bahan per kontainer (dalam fraksi satu hari).

c : kuantitas container standar untuk part. $\alpha$ : suatu variabel kebijaksanaan yang merefleksikan efisiensi stasiun kerja memproduksi atau menggunakan part (Toyota menggunakan $\leq 10 \%$ ).

\subsection{Pengujian Data}

Pengukuran waktu ini menggunakan jam henti (stopwatch) sebagai alat utamanya. Cara ini merupakan cara yang paling banyak dikenal, dan karenanya banyak digunakan. Salah satu yang menyebabkan adalah keserderhanaan aturan-aturan ajaran yang dipakai (Iftikar Z. Sutalaksana). Pengaturan waktu ini dalam pengambilan data waktu langsung disebelah operator dan pengambilan datanya disesuaikan dengan kebutuhan.

$>$ Hitung rata-rata dari harga rata-rata sub grub dengan:

$$
\overline{\bar{X}}=\frac{\sum X i}{k}
$$

Dimana:

$x=$ harga rata-rata dari sub grup ke-1.

$\mathrm{k}$ = harga banyaknya sub grup yang terbentuk.

Hitung standard deviasi sebenarnya dari waktu penyelesaian dengan:

$$
\sigma=\sqrt{\frac{\sum\left(X_{j}-\overline{\bar{x}}\right)^{2}}{n-1}}
$$

Dimana:

$n$ = jumlah pengamatan pendahuluan yang telah dilakukan.

$X=$ waktu penyelesaian yang teramati selama pengukuran pendahuluan yang telah dilakukan.

Hitung standar deviasi dari distribusi harga rata-rata sub grup dengan:

$$
\sigma \bar{x}=\frac{\sigma}{\sqrt{n}}
$$

Dimana: $\mathrm{n}=$ besarnya sub grup.

Tentukan Batas Kontrol Atas dan Batas Kontrol Bawah (BKA dan BKB) dengan:

$$
B K A=\bar{X}+3 \sigma \bar{x}
$$


Menghitung banyaknya pengukuran yang diperlukan dengan:

$$
N^{\prime}=\left[\frac{40 \sqrt{N \sum x_{i}^{2}-\left(\sum x_{i}\right)^{2}}}{\sum x_{i}}\right]^{2}
$$

dimana:

$$
\begin{aligned}
& \mathrm{N}=\text { jumlah pengamatan yang telah } \\
& \text { dilakukan. }
\end{aligned}
$$

\subsection{Perhitungan Waktu Baku}

Hitung waktu siklus rata-rata dengan:

$$
W s=\frac{\sum X_{i}}{N}
$$

Dimana $\mathrm{X}_{\mathrm{i}}$ dan $\mathrm{N}$ menunjukkan arti yang sama dengan yang telah dibahas selanjutnya.

Hitung waktu normal dengan:

$$
W n=W s * p
$$

Dimana $\mathrm{p}$ adalah faktor penyesuaian. Faktor ini diperhitungkan jika pengukur berpendapat bahwa operator bekerja dengan kecepatan tidak wajar, sehingga hasil perhitungan waktu perlu disesuaikan atau dinormalkan dulu untuk mendapat waktu silkus rata-rata yang wajar. Jika pekerja bekerja dengan wajar, maka faktor penyesuaiannya $\mathrm{p}$ sama dengan 1 , artinya waktu siklus rata-rata sudah normal. Jika bekerjanya terlalu lambat maka untuk menormalkannya pengukur harus memberi harga $p<1$, dan sebaliknya $p>1$ jika dianggap bekerja cepat.

Hitung waktu baku dengan:

$$
W b=W n+(W n * \text { Allowance })
$$

Allowance diberikan diberikan kepada pekerja untuk mengerjakan pekerjaannya disamping waktu normal. Kelonggaran ini diberikan untuk hal-hal seperti kebutuhan pribadi, menghilangkan rasa fatique dan gangguan-gangguan yang mungkin terjadi yang tidak dapat dihin-

\begin{tabular}{|c|c|c|}
\hline \multirow{2}{*}{$\begin{array}{l}\text { Waktu } \\
\text { SIklus }\end{array}$} & \multicolumn{2}{|c|}{ Sub Grup } \\
\hline & 1 & 2 \\
\hline 1 & 93,36 & 93,56 \\
\hline 2 & 94,27 & 93,16 \\
\hline 3 & 93,21 & 92,34 \\
\hline 4 & 92,46 & 92,45 \\
\hline 5 & 93,29 & 93,43 \\
\hline 6 & 93,46 & 93,07 \\
\hline 7 & 92,31 & 93,24 \\
\hline 8 & 93,11 & 94,21 \\
\hline 9 & 94,54 & 93,31 \\
\hline 10 & 92,02 & 93,26 \\
\hline$\Sigma$ & 932,03 & 932,03 \\
\hline Rata2 & 93,2 & 93,2 \\
\hline
\end{tabular}
darkan oleh pekerja. Umumnya kelong- garan dinyatakan dalam persendari waktu normal.

\section{Analisis dan Pengolahan Data}

6.1. Uji Keseragaman Data

Diketahui:

$$
\begin{aligned}
& \bar{x}_{1}=93,2 \quad \bar{x}_{2}=93.2 \\
& \mathrm{~m}=2 \Rightarrow \text { jumlah sub group } \\
& \overline{\bar{x}}=\frac{\sum \bar{x}}{m}=\frac{93,2+93,2}{2}=93,2 \\
& \begin{aligned}
\sigma & =\sqrt{\frac{\sum\left(x_{j}-\overline{\bar{x}}\right)^{2}}{n-1}} \\
& =\sqrt{\frac{(93,36-93,2)^{2}+(94,27-93,2)^{2}+\ldots .+(93,31-93,2)^{2}+(93,26-93,2)^{2}}{20-1}} \\
= & \sqrt{\frac{8,3226}{19}}=\sqrt{0,438}=0,6618 \\
\sigma \bar{x} & =\frac{\sigma}{\sqrt{n}}=\frac{0.6618}{\sqrt{2}}=0.468 \\
\text { BKA } & =\bar{x}+3(\sigma \bar{x})=93,2+3(0.468)=93,2+1,404=94,604 \\
\text { BKB } & =\bar{x}-3(\sigma \bar{x})=93,2-3(0,468)=93,2-1,404=91,796
\end{aligned}
\end{aligned}
$$

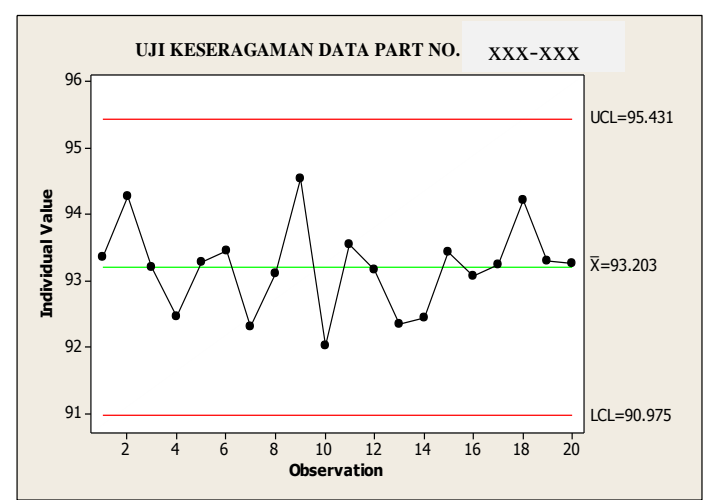

Gambar 4. Grafik Uji Keseragaman Data 


\subsection{Uji Kecukupan Data}

Uji kecukupan data dilakukan untuk mengetahui apakah data waktu siklus yang diambil sudah cukup apa belum. Jumlah pengukuran data dikatakan cukup apabila jumlah pengukuran yang dilakukan telah memenuhi jumlah pengukuran yang diper-lukan $\left(\mathrm{N}^{\prime}<\mathrm{N}\right)$.

$$
\begin{aligned}
& N^{\prime}=\left[\frac{40 \sqrt{N \sum x_{i}^{2}-\left(\sum x_{i}\right)^{2}}}{\sum x_{i}}\right]^{2} \\
& N^{\prime}=\left(\frac{40 \sqrt{20 * 173744,3066-(3474719,684)}}{1864,06}\right)^{2} \\
& N^{\prime}=\left(\frac{516,06}{1864,06}\right)^{2} \\
& N^{\prime}=(0,277)^{2} \rightarrow N^{\prime}=0,077
\end{aligned}
$$

\subsection{Faktor Kelonggaran}

Faktor kelonggaran diberikan untuk 3 hal berikut yaitu kebutuhan pribadi, menghilangkan rasa fatique, dan hambatan-hambatan yang tidak dapat dihindarkan.

1. Tenaga yang dikeluarkan Sangat ringan (bekerja dimesin, berdiri)

2. Sikap kerja Berdiri diatas 2 kaki

Gerakan kerja Normal (ayunan bebas)

4. Kelelahan mata Pandangan yang hampir terus menerus $\quad 6 \%$

5. Keadaan temperatur tempat kerja Normal $\left(22^{\circ}-28^{\circ}\right)$

6. Keadaan Atmosfir Baik (ruang yang berventilasi baik, udara segar)

7. Keadaan lingkungan yang baik Sangat bising

Jadi presentase kelonggaran untuk kebutuhan pribadi dan untuk fatique sebagai berikut:

$\Rightarrow 6 \%+1 \%+0 \%+6 \%+0 \%+0 \%+3 \%=16 \%$.

Kelonggaran untuk hambatan yang tidak terhindarkan (efisiensi) adalah 20\% (ditetapkan oleh pabrik), maka kelonggaran total yang harus diberikan adalah $16 \%+20 \%$ $=36 \%$

\subsection{Perhitungan Waktu Baku}

$$
\begin{aligned}
W s & =\frac{\sum X_{i}}{N} \\
& =\frac{1864}{20}=93,2 \\
W n & =W s \times P \\
& =93,2 \times 1,25 \\
& =116,5 \\
W b & =W n+(\text { Wn } * \text { Allowance }) \\
& =116,5+(116,5 * 0.36) \\
& =158,44
\end{aligned}
$$

\subsection{Perhitungan Jumlah Kanban}

- Rata-rata permintaan harian =

Permintaan dalam satu bulan Jumlah hari kerja $=\frac{6074}{23}=265$ unit

- kuantitas container $=10$ unit

- $\quad$ waktu siklus dalam periode 1 hari =

$$
\frac{\text { Waktu siklus per part }}{\text { Jumlah jam keja }}
$$

$$
=\frac{158,44}{60 * 60 * 16}=0,00275 \text { hari }
$$

- $(\bar{w}+\bar{p})=$ waktu siklus dalam periode 1 hari ${ }^{*} c=0,00275 * 10=0,0275$ hari

- Berdasarkan perhitungan-perhitungan di atas maka di dapatkan jumlah kartu Kanban sebagai berikut:

$$
\begin{aligned}
& k=\frac{d(\bar{w}+\bar{p})(1+\alpha)}{c} \\
& k=\frac{265(0,0275)(1+0)}{10} \\
& k=0,729 \approx 1 \text { kartu }
\end{aligned}
$$




\section{KESIMPULAN DAN SARAN}

\subsection{Kesimpulan}

Berdasarkan pengolahan data dan analisa data-data yang penulis dapatkan selama menyusun Laporan Kerja Praktek ini didapatkan kesimpulan sebagai berikut:

1. Pengujian keseragaman data yang telah dilakukan menyatakan bahwa data yang dikumpulkan berasal dari populasi yang sama (seragam). Hal ini dikarenakan data berada direntang BKA dan BKB.

2. Hasil pengujian kecukupan data menunjukkan bawah $\mathrm{N}^{\prime}<\mathrm{N}$. Hal ini dapat dinyatakan bahwa data yang dikumpulkan sudah mencukupi untuk dilakukan pengolaha data selanjutnya.

3. Jumlah Kanban yang dibutuhkan pada Proses Produksi Support Assy Brake Pedal Part No. $x x x x-x x x x d i$ Departemen Welding PT. NTC berjumlah 1 (satu).

\subsection{Saran}

Agar Sistem Kanban dapat berjalan dengan baik, perlu dilakukan tindakan-tindakan sebagai berikut:

1. Memberikan pemahaman kepada semua operator/staff untuk melakukan perbaikan secara terus-menerus (kaizen).

2. Memberikan pemahaman kepada setiap operator agar menghasilkan part dengan kualitas yang baik karena salah satu tujuan dari sistem JIT adalah zero defect.

3. Mengurangi safety stock pada stasiun kerja secara berkala.

4. Melakukan standarisasi dan metode kerja untuk efisiensi kerja.

5. Melakukan analisa ketergantungan dan keseimbangan lintasan (line balancing) antar stasiun kerja dalam lintasan lantai produksi.

\section{DAFTAR PUSTAKA}

Gaspersz, Vincent. 1998. Production Planning And Inventory Control Berdasarkan Sistem Terintegrasi MRP II Dan JIT Menuju Manufacturing 21. Jakarta: Gramedia Pustaka Utama.

Monden, Yasuhiro. 1995. Sistem Produksi Toyota, Buku Pertama. PT. Pustaka Binaman Pressindo.

Monden, Yasuhiro. 1995. Sistem Produksi Toyota. Buku Kedua. PT. Pustaka Binaman Pressindo.

Schroeder, Roger G. 1997. Manajemen Operasi Pengambilan Keputusan dalam Suatu Fungsi Operasi. Jilid ke-2. Jakarta: Erlangga.

Subagyo, Pangestu, Manajemen Operasi, Yogyakarta, BPFE, 2000.

Sutalaksana, Iftikar Z. 1979. Teknik Tata Cara Kerja. Jurusan Teknik Industri: Institut Teknologi Bandung. 


\title{
PERANCANGAN APLIKASI OP-AMP DENGAN SOFTWARE GUI MATLAB
}

\author{
Triyono \\ Program Studi Teknik Elektro \\ Fakultas Teknik \\ Universitas Muhammadiyah Tangerang \\ Jl. Perintis Kemerdekaan I/33, Cikokol, Kota Tangerang \\ E-mail: lover_mu_1980@yahoo.co.id
}

\begin{abstract}
ABSTRAK
Operational Amplifier (OP-AMP) merupakan rangkaian penguat yang menjadi basis dari rangkaian audio dan video amplifier, filter, buffer (penyangga), komparator, oscilator dan rangkaian analog lainnya. Untuk meningkatkan pemahaman mahasiswa dalam merancang rangkaian OP-AMP dapat digunakan media pembelajaran berbantuan komputer. Matlab merupakan software yang digunakan dalam pembelajaran untuk melihat tanggapan beragam parameter dan masukan yang berbeda. Dari hasil penelitian didapatkan hasil yang cukup signifikan dalam peningkatan pemahaman mahasiswa dalam perancangan rangkaian OP-AMP.
\end{abstract}

Kata Kunci: OP-AMP, Matlab, Analog.

\section{PENDAHULUAN}

Operational Amplifier (OP-AMP) telah digunakan bertahun-tahun. Awalnya OPAMP dibentuk menggunakan sirkuit diskrit transistor, setelah perkembangan teknologi integrated ciruit (IC) telah merevolusi desain rangkaian analog. OP-AMP merupakan yang pertama sebuah IC analog, hal ini dikarenakan fungsinya yang sangat bermanfaat penggunaannya dalam beragam rangkaian.

Popularitas OP-AMP disebabkan oleh fleksibilitasnya. High-gain penguat DC yang memiliki input diferensial tegangan output adalah perbedaan tegangan antara dua input dikalikan dengan gain. Komponen pasif bisa digunakan untuk memberikan umpan balik, dan ini mengatur gain dan fungsi sirkuit OPAMP keseluruhan. Komponen umpan balik negatif pasif mengakibatkan linear respon, yaitu output sebanding dengan input. Umpan balik positif pasif hasil dalam switching atau osilasi. Komponen kadang-kadang aktif seperti transistor dan dioda digunakan dalam loop umpan balik untuk memberikan respon non-linear.

Permasalahan yang dihadapi dalam perancangan OP-AMP adalah mendapatkan nilai gain, output dan fungsi grafik rangkaian tersebut. Setelah didapatkan permasalahan selanjutnya adalah menganalisisnya apakah rangkaian yang dibuat berjalan dengan baik atau tidak. Seringkali mahasiswa mengalami kesulitan dalam menganalisis sistem, namun dengan bantuan software matlab proses analisis sistem menjadi jauh lebih mudah dan cepat sehingga akan memudahkan dalam proses pembelajaran terutama dalam perancangan sistem dengan menggunakan rangkaian OP-AMP.

\section{OPERATIONAL AMPLIFIER}

Pada OP-AMP terdapat satu terminal keluaran, dan dua terminal masukan. Terminal masukan yang diberi tanda (-) dinamakan terminal masukan pembalik (inverting), sedangkan terminal masukan yang diberi (+) 
dinamakan terminal masukan bukan pembalik (noninverting). Berikut merupakan gambar simbol OP-AMP.

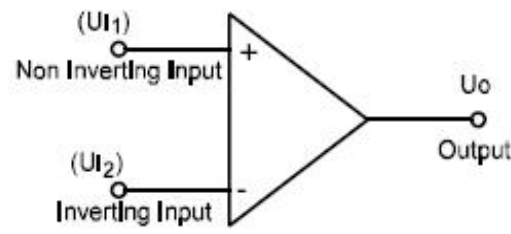

Gambar 1. Simbol OP-AMP

Jika input OP-AMP diberi tegangan searah dengan input Non Inverting $(+)$ lebih besar dari pada input inverting (-), maka pada output OP-AMP akan positif (+). Sebaliknya jika input Non Inverting (+) lebih kecil dari pada input inverting (-), maka output OP-AMP akan negatif (-).

Tabel 1. Perbedaan parameter beberapa OP-AMP

\begin{tabular}{|l|l|l|l|l|}
\hline Parameter & Ideal & LM741 & LF347 & LM318 \\
\hline Open-loop Gain $\left(\mathrm{A}_{\text {oL }}\right)$ & $\infty$ & $2.10^{5}$ & $10^{5}$ & $2.10^{5}$ \\
\hline Input Resistance $\left(\mathrm{R}_{\text {in }}\right)$ & $\infty \Omega$ & $2 \mathrm{M} \Omega$ & $10^{12} \Omega$ & $3 \mathrm{M} \Omega$ \\
\hline Output Resistance $\left(\mathrm{R}_{\mathrm{o}}\right)$ & $0 \Omega$ & $75 \Omega$ & $75 \Omega$ & $75 \Omega$ \\
\hline Gain Bandwidth Product & $\infty \mathrm{Hz}$ & $1 \mathrm{MHz}$ & $4 \mathrm{MHz}$ & $15 \mathrm{MHz}$ \\
\hline CMRR & $\infty$ & $90 \mathrm{~dB}$ & $100 \mathrm{~dB}$ & $100 \mathrm{~dB}$ \\
\hline
\end{tabular}

\subsection{Penguat Inverting}

Rangkaian dasar penguat inverting adalah seperti yang ditunjukkan pada gambar 2, dimana sinyal masukannya dibuat melalui input inverting.

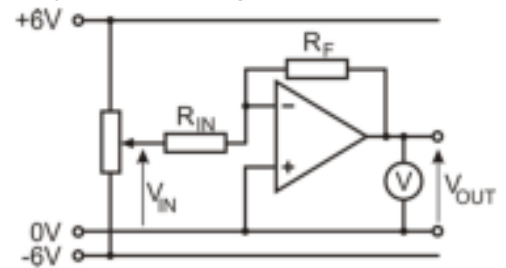

Gambar 2. Penguat Inverting Input non-inverting pada rangkaian

ini dihubungkan ke ground, atau $\mathrm{V}^{+}=0$. Karena nilainya $=0$, namun tidak terhubung langsung ke ground, input op-amp $\mathrm{V}^{-}$pada rangkaian ini dinamakan virtual ground. Dengan demikian dapat dihitung tegangan jepit pada $R_{\text {in }}$ adalah $\mathrm{V}_{\text {in }}-\mathrm{V}^{-}=\mathrm{V}_{\text {in }}$ dan tegangan jepit pada resistor $\mathrm{Rf}$ adalah $\mathrm{V}_{\text {out }}$
$-v^{-}=V_{\text {out. }}$ Kemudian di ketahui bahwa: iin

+ iout $=\mathrm{i}^{-}=0$, arus masukan op-amp adalah 0 . Maka: iin + i out $_{\text {oun }}=V_{\text {in }} / R_{\text {in }}+V_{\text {out }} / R_{f}=0$, Selanjutnya $V_{\text {out }} / R_{f}=-V_{\text {in }} / R_{\text {in }}$ atau $V_{\text {out }} / \mathrm{V}_{\text {in }}=-\mathrm{Rf}_{\mathrm{f}} / \mathrm{Rin}$. Jika penguatan $\mathrm{G}$ didefenisikan sebagai perbandingan tegangan keluaran terhadap tegangan masukan, maka dapat ditulis $\mathrm{G}=\mathrm{V}_{\mathrm{out}} / \mathrm{Rf}=\mathrm{-}$ $V_{\text {in }} / R_{\text {in }}$.

\subsection{Peenguat Non-Inverting}

Rangkaian dasar penguat inverting adalah seperti yang ditunjukkan pada gambar 3, dimana sinyal masukannya dibuat melalui input non-inverting. Dengan demikian tegangan keluaran rangkaian ini akan satu fasa dengan tegangan inputnya.

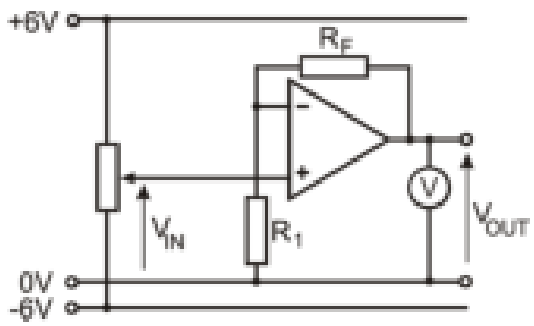

Gambar 3. Penguat Non-Inverting

Jika: $\mathrm{V}_{\text {in }}=\mathrm{V}^{+}$dan $\mathrm{V}^{+}=\mathrm{V}^{-}=\mathrm{V}_{\text {in }}$. Dari sini ketahui tegangan jepit pada $\mathrm{Rf}$ adalah $V_{\text {out }}$ $-\mathrm{V}^{-}=\mathrm{V}_{\text {out }}-\mathrm{V}_{\text {in }}$, atau iout $=\left(\mathrm{V}_{\text {out }}-\mathrm{V}_{\text {in }}\right) / \mathrm{Rf}$. Lalu tegangan jepit pada $R_{1}$ adalah $V^{-}=V_{i n}$, yang berarti arus $i R_{1}=V_{i n} / R_{1}$. Hukum kirchoff pada titik input inverting bahwa iout $+\mathrm{i}(-)=\mathrm{iR} 1$ serta $\mathrm{i}(-)=0$ dan jika disubsitusi ke rumus yang sebelumnya, maka diperoleh iout $=i R 1$ dan Jika ditulis dengan tegangan jepit masing-masing maka diperoleh ( $V_{\text {out }}$ $\left.V_{\text {in }}\right) / R f=V_{\text {in }} / R 1$ yang kemudian dapat disederhanakan menjadi: $V_{\text {out }}=V_{\text {in }}(1+$ $\mathrm{Rf} / \mathrm{R} 1)$. Jika penguatan $\mathrm{G}$ adalah perbandingan tegangan keluaran terhadap tegangan masukan, maka didapat penguatan op-amp non-inverting: $\mathrm{G}=\mathrm{V}_{\text {out }} / \mathrm{V}_{\text {in }}=(1+$ $\mathrm{Rf} / \mathrm{R} 1)$. 


\subsection{Voltage Follower}

Rangkaian dasar penguat voltage follower adalah seperti yang ditunjukkan pada gambar 4, rangkaian voltage follower berguna untuk meningkat arus tanpa mengubah tegangannya. Digunakan untuk mengubah sinyal berimpedansi tinggi menjadi sinyal berimpedansi rendah yang kokoh (robust). Gain voltage follower 1.

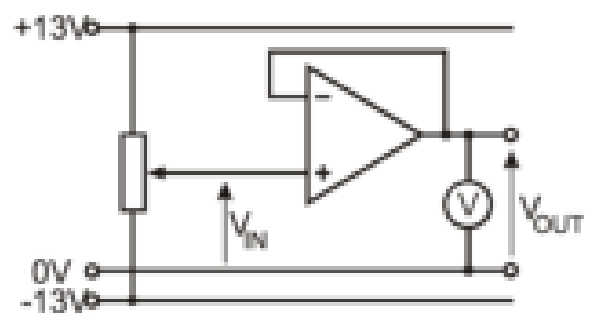

Gambar 4. Voltage Follower

$\mathrm{R}$ in adalah tahananan yang sangat besar dan $\mathrm{R}$ adalah tahananan yang sangat kecil. Kembali ke persamaan awal saat Vout sama dengan V1 maka persamaan awal menjadi:

$$
V_{\text {out }}=A\left(V^{+}-V_{-} \text {out }\right)
$$

sehingga bila Vout yang dicari maka persamaan menjadi:

$$
V_{\text {out }}=\frac{A V^{+}}{1+A} \approx V^{+}
$$

\subsection{Summing Amplifier}

Rangkaian dasar penguat summing amplifier adalah seperti yang ditunjukkan pada gambar 5, summing amplifier digunakan sebagai penjumlah tegangan. Summing amplifier dapat digunakan untuk menjumlah tegangan dari beberapa sumber yang memiliki arus yang berbeda.

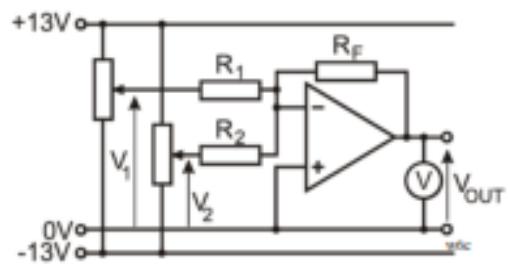

Gambar 5. Summing Amplifier

Persamaan tegangan keluaran ditentukan sebagai berikut:

$$
V_{\text {out }}=-\left(\frac{R_{f}}{R_{1}} V_{1}+\frac{R_{f}}{R_{2}} V_{2}\right)
$$

\subsection{Differential Amplifier}

Rangkaian dasar penguat differential amplifier adalah seperti yang ditunjukkan pada gambar 6, differential amplifier merupakan amplifier yang digunakan untuk mencari selisih tegangan dari dua sinyal yang masuk.

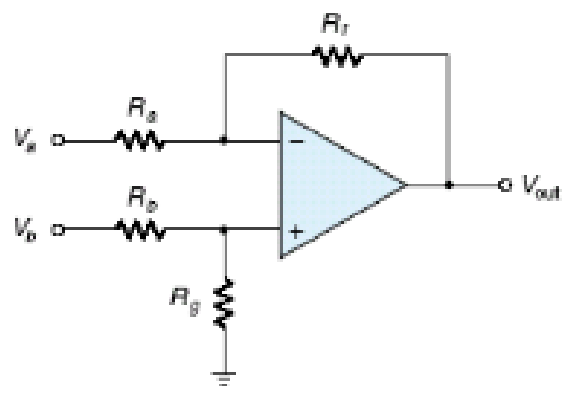

Gambar 5. Differential Amplifier

Persamaan tegangan output-nya dinyatakan sebagai berikut:

$$
V_{\text {out }}=\frac{R_{f}}{R_{a}}\left(V_{b}-V_{a}\right)
$$

Tegangan output merupakan tegangan tunggal yang mengacu pada ground biasanya disebut single ended voltage. 


\section{Metodologi Penelitian}

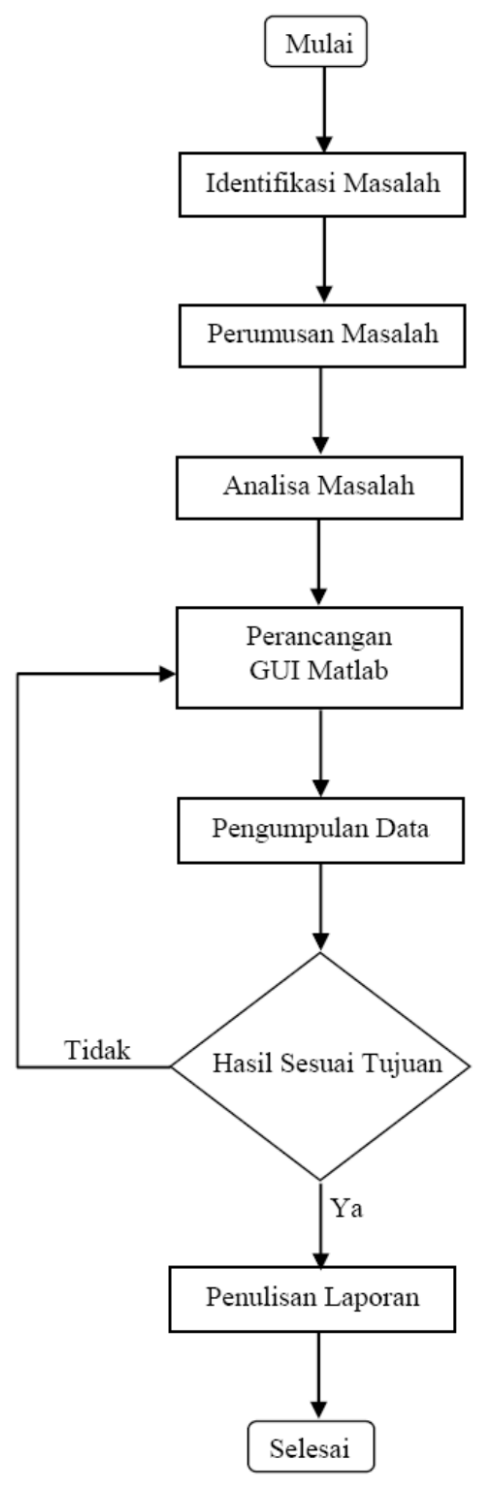

\section{Hasil}

Rancangan aplikasi GUI Op-Amp diujicobakan kepada mahasiswa dibandingkan dengan menggunakan metode praktikum, metode perhitungan manual. Setelah dilakukan tindakan kelas terjadi peningkatan yang cukup signifikan terhadap pemahaman dan ketertarikan mahasiswa dalam mempelajari materi analog berbasis operational amplifier pada mata kuliah Teknik Analog dan Digital. Hal ini menunjukkan bahwa penggunaan GUI matlan sangat membantu dosen dalam menyampaikan materi operational amplifier kepada mahasiswa. Penggunaan Matlab tidak hanya pada operational amplifier semata, tetapi dapat dikembangkan pada materi-materi yang berhubungan dengan kendali maupun sinyal.

\section{Kesimpulan}

Berdasarkan hasil pembahasan yang dilakukan dapat diambil beberapa kesimpulan sebagai berikut:

a. Pengembangan GUI MATLAB untuk aplikasi Op-Amp sangat membantu mahasiswa dalam memahami materi secara keseluruhan.

b. Perancangan GUI MATLAB untuk aplikasi Op-Amp sangat memudahkan untuk mendapatkan hasil perhitungan yang tepat.

c. Penerimaan materi GUI MATLAB untuk aplikasi Op-Amp lebih baik dibandingkan dengan metode pembelajaran konvensional.

d. Pengembangan metode pembelajaran kreatif, inovatif dan terbarukan perlu terus ditingkatkan untuk meningkatkan pemahaman dan prestasi mahasiswa yang lebih baik dalam mempelajari materi.

\section{DAFTAR PUSTAKA}

Annonymous. 2010. Loctronics Simplifying Electricity Operational Amplifier. Matrix Multimedia

Attia, John Okyere. 1999. Electronics and circuit analysis using MATLAB. CRC Press.

Clayton, George and Winder, Steve. 2003. Operational Amplifiers Fifth Edition. Newnes.

Jung, Walt. ed. 2005. Op Amp Applications Handbook. Newnes 


\section{Lampiran \\ Perancangan Aplikasi OP-AMP Dengan Software GUI Matlab}

\section{Inverting Amplifier}

kasus 1

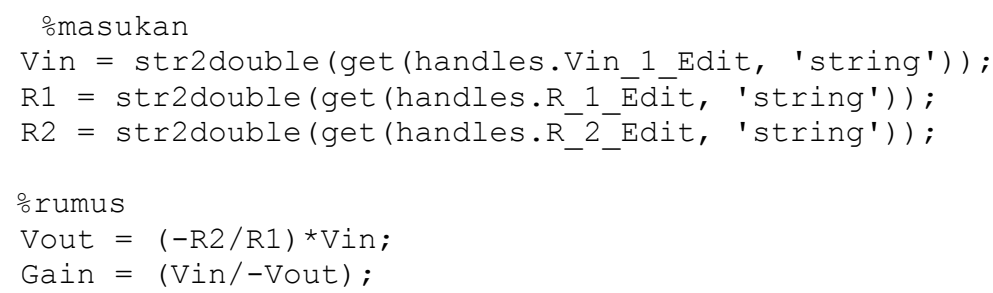




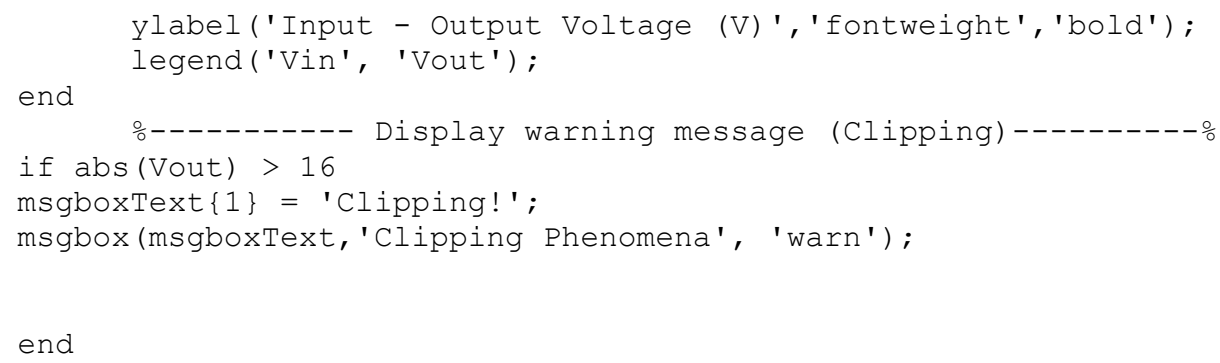

\section{Non-Inverting Amplifier}

\section{kasus 2}

omasukan

Vin = str2double (get (handles.Vin_1_Edit, 'string'));
R1 = str2double (get (handles.R 1 Edit, 'string'));

R2 = str2double (get (handles.R_2_Edit, 'string'));

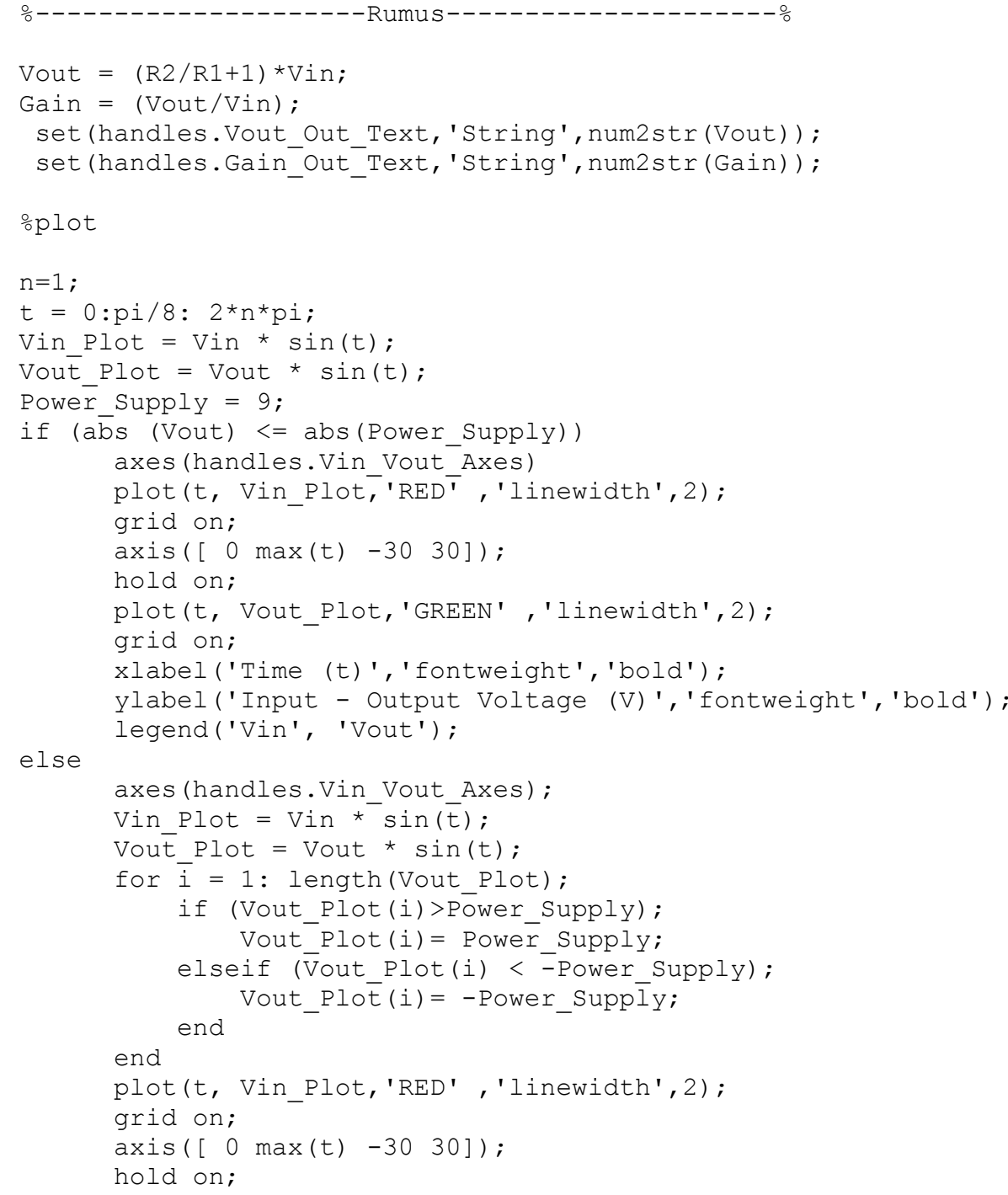




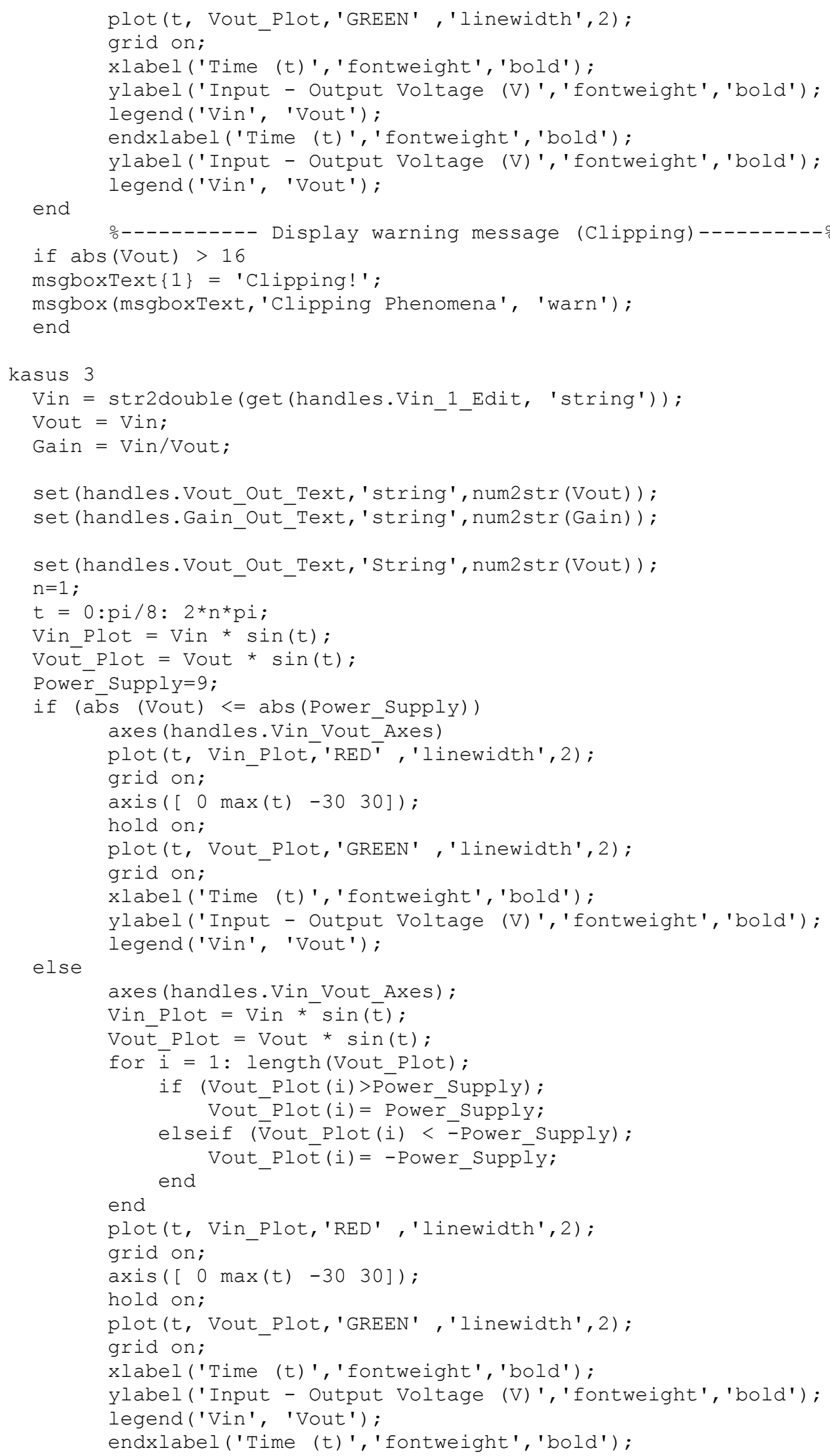




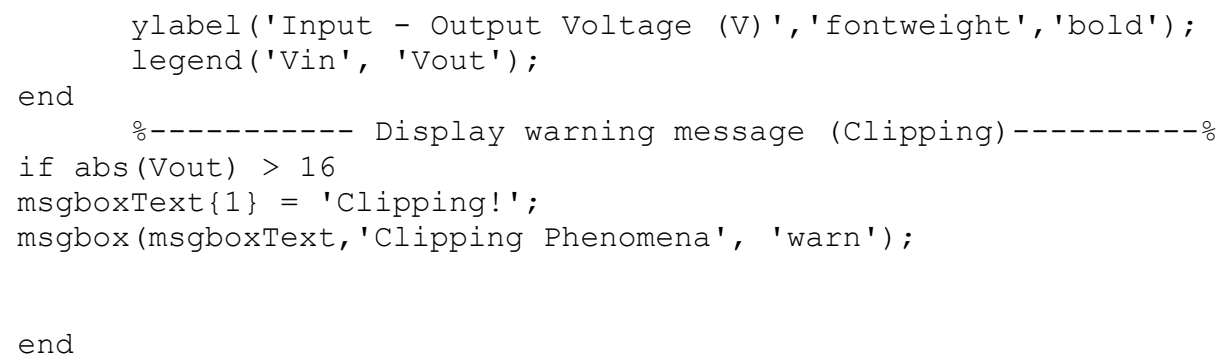

\section{Summing Amplifier}

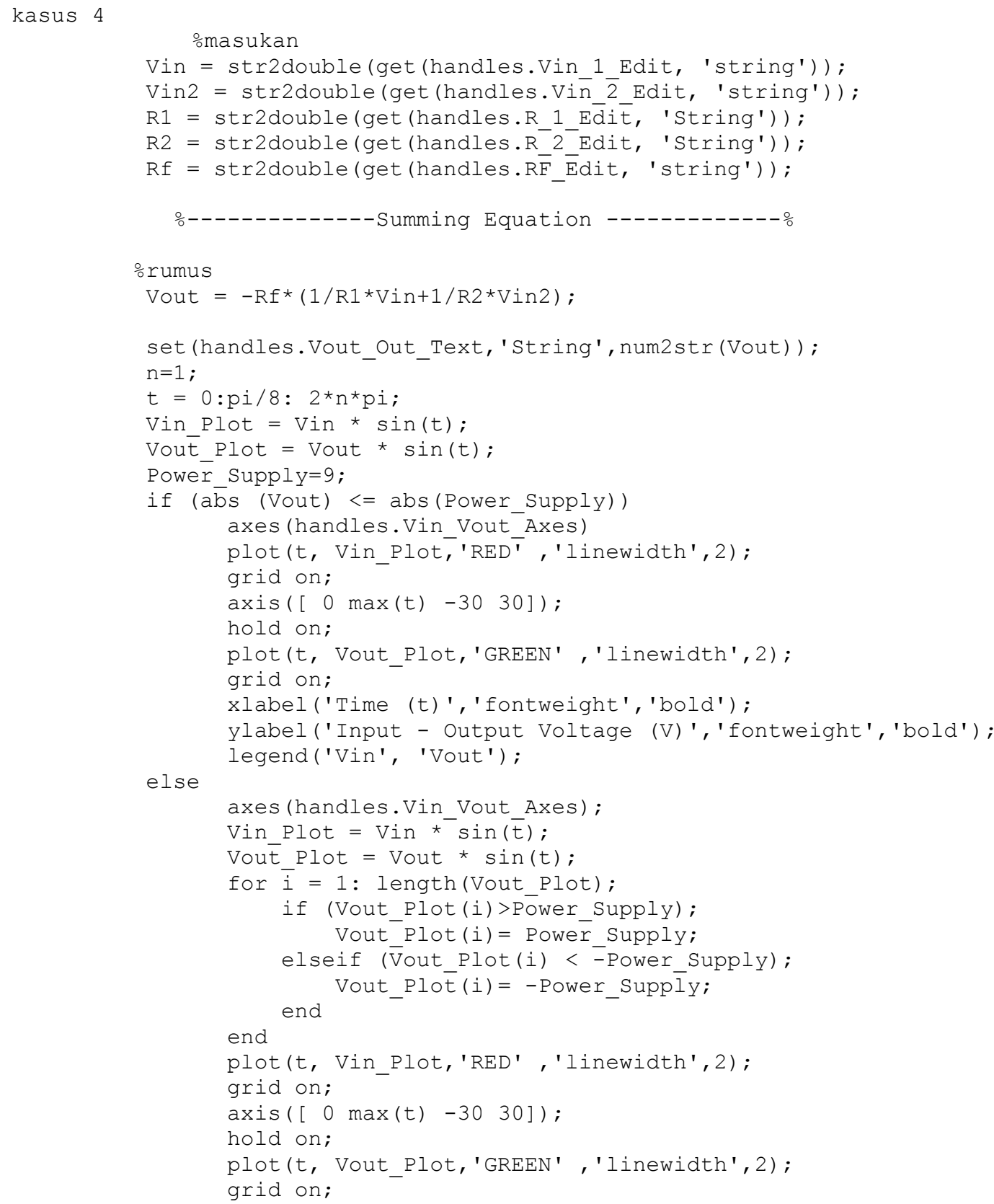




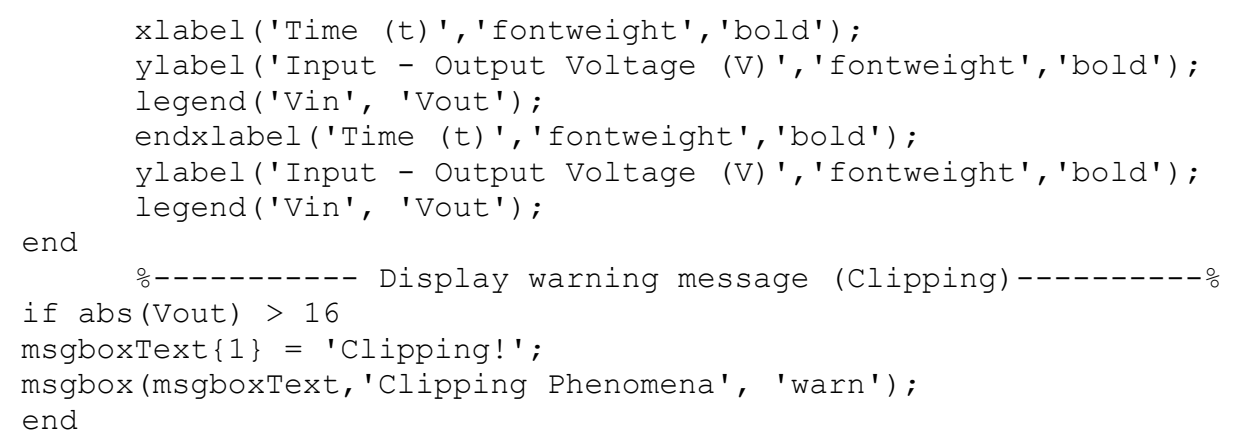

\section{Differential Amplifier}

kasus 5

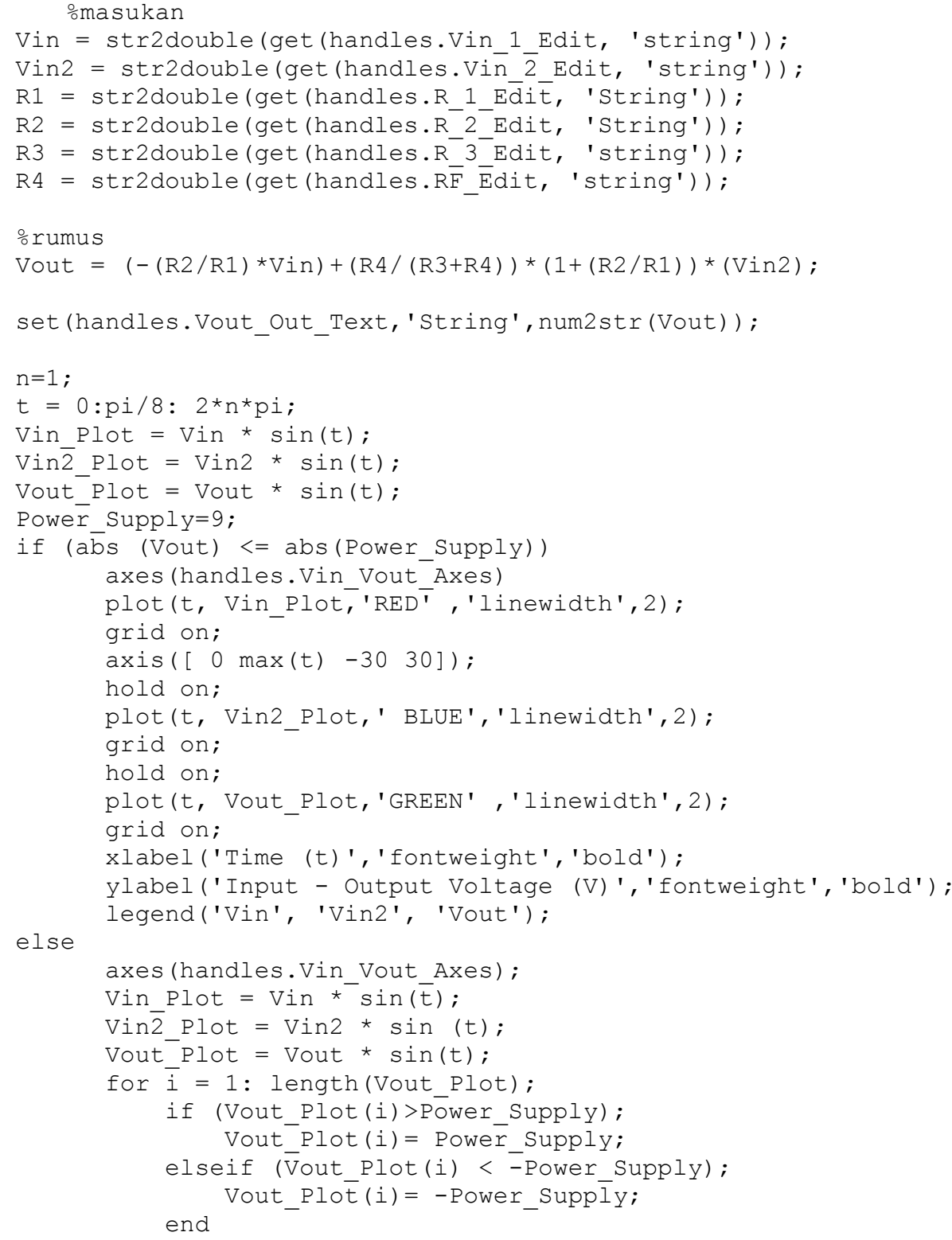




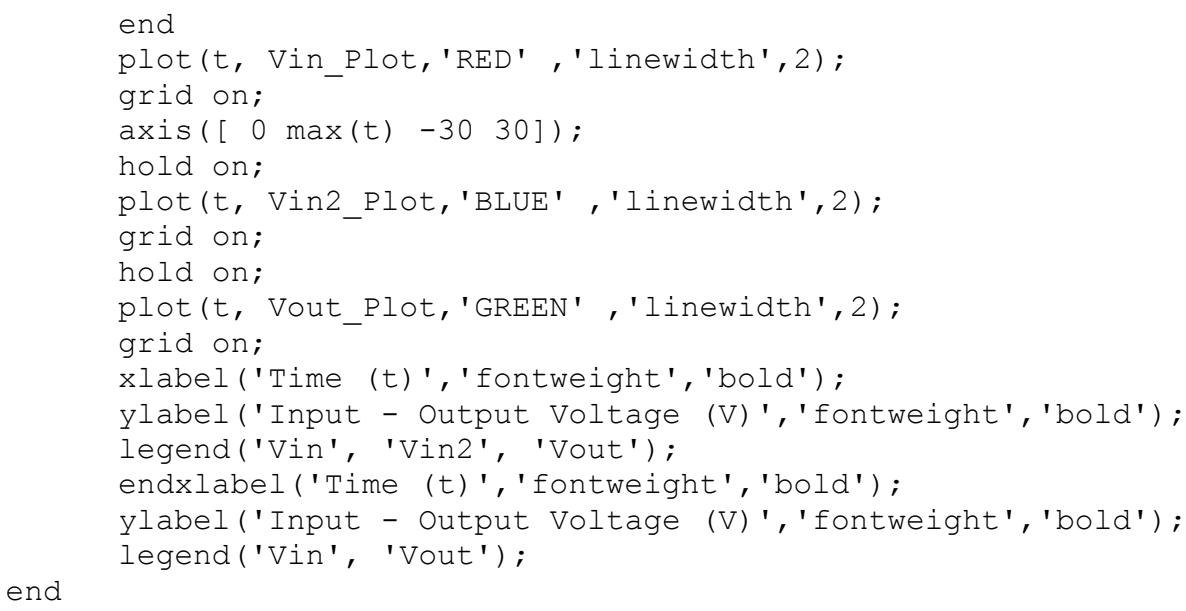




\title{
STUDI EKSPERIMENTAL PENGUJIAN KEKASARAN PERMUKAAN DAN KEAKURASIAN DIMENSI PADA PROSES DRY MACHINING BAJA AISI 01
}

\author{
Riki Candra Putra \\ Jurusan Teknik Mesin \\ Universitas Muhammadiyah Tangerang
}

\begin{abstract}
ABSTRAK
Akhir-akhir ini proses pemesinan banyak menimbulkan dampak negatif terhadap lingkungan dan pekerja. Hal ini banyak disebabkan oleh penggunaan cairan pendingin (flood coolant) untuk mendinginkan proses pemotongan pada saat pahat memotong benda kerja.

Oleh karena itu para ilmuwan saat ini berusaha untuk mengurangi dampakdampak yang diakibatkan oleh penggunaan cairan fluida tersebut. Salah satu metode yang digunakan adalah proses Dry Machining.

Proses Dry machining adalah proses yang dilakukan pada proses pemotongan logam tanpa menggunakan fluida pendingin/cutting fluid. Proses ini dapat menguntungkan karena dapat mengurangi biaya yang besar pada proses pemesinan. Akan tetapi dry machining dapat menimbulkan temperatur yang sangat tinggi pada benda kerja dan pahat sehingga menimbulkan kekasaran permukaan yang tinggi dan ketidak akurasian dimensi.

Percobaan dilakukan dengan menggunakan salah satu jenis proses pemesinan yaitu proses pembubutan, dengan menggunakan benda kerja AISI 01 pada kekerasan yang tinggi dan pahat CBN. Penelitian ini bertujuan untuk melihat tingkat kekasaran permukaan yang terjadi dan keakurasian dimensi yang dicapat pada benda kerja.

Hasil yang didapat dari percobaan ini yaitu didapat tingkat kekasaran permukaan yang halus dan tingkat keakurasian dan penyimpangan atau variasi dimensi hingga $0.011 \mathrm{~mm}$. Manfaat yang dapat diambil dari percobaan ini adalah digunakannya $d r y$ machining sebagai dasar pertimbangan dalam menentukan metode alternatif pemotongan logam yang tepat guna.
\end{abstract}

Kata Kunci: Dry Machining, heat treatment, Keakurasian, Mesin Bubut.

\section{PENDAHULUAN}

Proses pemesinan merupakan metode pengerjaan logam yang sangat populer. Proses ini memegang peranan penting dalam industri manufaktur karena hampir semua produk yang dibuat melalui proses tuang (casting) maupun pembentukan (forming) memerlukan proses pengerjaan akhir (finishing) dengan cara di machining. Disamping itu, proses pemesinan mampu menghasilkan komponen-komponen mekanik yang mampu tukar untuk keperluan perakitan. Kelebihan lainnya adalah bahwa proses pemesinan mampu menghasilkan kekasaran permukaan yang baik sehingga proses ini sangat sesuai untuk membuat komponen-komponen mesin yang menitikberatkan pada kehalusan permukaan [1].

Salah satu benda kerja yang dilakukan proses pemesinan adalah baja AISI 01 . Material ini secara luar digunakan untuk komponen mesin, misalnya gear, piston, nozzle, dies dan cams serta untuk aplikasi perkakas pada proses pengerjaan dingin seperti roll, punch dan forging [2]. 
Akhir-akhir ini proses pemesinan banyak menimbulkan dampak negatif terhadap lingkungan dan pekerja. Hal ini banyak disebabkan oleh penggunaan cairan pendingin (flood coolant) untuk mendinginkan proses pemotongan pada saat pahat memotong benda kerja, karena untuk menghindari pemanasan yang tinggi yang dapat berakibat rusaknya benda kerja dan pahat, dampak - dampak negatif tersebut antara lain [3].

- Akibat polusi limbah cair sisa pemakaian cairan pendingin yang bisa merusak lingkungan yang disebabkan tidak tepatnya dalam penanganan sisa-sisa cairan pendingin tersebut.

- Berbahaya terhadap kesehatan operator karena reaksi kimia yang terjadi antara cairan dengan kulit.

Selain itu karena harga cairan pendingin yang begitu mahal sehingga dapat menyebabkan tingginya biaya yang harus dialokasikan oleh perusahaan hanya untuk cairan pendingin.

Oleh karena itu para ilmuwan saat ini berusaha untuk mengurangi dampak-dampak yang diakibatkan oleh penggunaan cairan fluida tersebut dengan menemukan metode terbaru adalah proses Dry $\mathrm{Ma}$ chining.

Dry machining merupakan proses pemesinan tanpa menggunakan cairan pendingin dalam memotong logam oleh pahat [3].

Akan tetapi dry machining dapat menimbulkan masalah-masalah pada proses pemesinan antara lain:

- Temperatur pahat dapat naik dengan sangat cepat, sehingga umur pahat menjadi lebih pendek.

- Keakurasian dimensi yang tidak ketat.

- Kekerasan (hardness) material dapat berkurang, material menjadi lebih ulet dan terjadinya perubahan struktur mikro dari material akibat meningkatnya temperatur.
Oleh karena itu pada penelitian ini akan dihasilkan dan dianalisa keuntungan-keuntungan dari proses dry machining dan dihindari masalah-masalah yang terjadi pada paragrap di atas.

Sehingga perlu dicari dan dikaji perumusan masalah pada penelitian ini, antara lain:

1) Bagaimana pengaruh proses dry machining terhadap kekasaran permukaan dan keakurasian dimensi.

2) Bagaimana perbandingan tingkat kekasaran permukaan teoritis dengan kekasaran permukaan sebenarnya (eksperimen).

3) Bagaimana hubungan kekasaran permukaan dengan panjang pemakanan.

4) Bagaimana kekakuan mesin bubut yang terjadi sewaktu pengerjaan benda kerja.

5) Toleransi dan keakurasian dimensi yang dicapai.

\section{TINJAUAN PUSTAKA}

\subsection{Proses pemotongan logam}

Proses pemotongan logam adalah merupakan suatu proses yang digunakan untuk mengubah suatu produk dari logam (komponen mesin) dengan cara pemotongan [4].

Proses pemotongan dengan menggunakan mesin perkakas dalam istilah teknik proses ini sering disebut proses pemesinan.

Proses pemesinan adalah proses pemotongan logam dengan pahat yang bergerak relatif terhadap benda kerja akan menghasilkan geram dan sementara itu permukaan benda kerja secara bertahap akan terbentuk menjadi komponen yang dikehendaki.

Pada proses pemesinan suatu pahat dipasangkan pada suatu jenis mesin perkakas dan dapat merupakan salah satu dari berbagai jenis pahat/perkakas potong yang disesuaikan dengan cara pemotongan dan bentuk akhir dari produk.

Gerak relatif dari pahat terhadap benda kerja dapat dipisahkan menjadi dua macam komponen gerakan yaitu gerak potong dan 
gerak makan. Pada penelitian ini proses pemesinan yang dilakukan menggunakan posisi benda kerja dalam posisi tetap dan gerak potong pahat mendekati benda kerja dan melakukan pemakanan. Kombinasi gerak potong dan gerak makan tersebut dilakukan oleh mesin bubut (Lathe).

\section{Elemen Dasar Proses Membubut}

Elemen dasar dari proses membubut dapat diketahui dengan menggunakan rumus yang dapat diturunkan. Kondisi pemotongan ditentukan sebagai berikut [4]:

$$
\begin{aligned}
& \text { Benda kerja; do = Diameter awal }(\mathrm{mm}) \\
& \mathrm{dm}=\text { Diameter akhir }(\mathrm{mm}) \\
& \text { Lt } \quad=\text { Panjang pemesinan }(\mathrm{mm}) \\
& \text { Pahat; } \quad \mathrm{Kr}=\text { Sudut potong utama }\left({ }^{\circ}\right) \\
& \text { yo }=\text { Sudut geram }\left({ }^{\circ}\right) \\
& r \quad=\quad \text { Radius ujung pahat }\left({ }^{\circ}\right)
\end{aligned}
$$

Kemudian untuk rumusan yang dipakai pada kerja mesin bubut adalah sebagai berikut:

$$
\begin{aligned}
& \mathrm{a}=\text { Kedalaman pemotongan } \frac{d o-d m}{3}(\mathrm{~mm}) \\
& \mathrm{f}=\text { Gerak makan }(\mathrm{mm} / \mathrm{r}) \\
& \mathbf{n}=\text { Putaran poros utama (benda kerja) }(\mathrm{r} / \mathrm{min})
\end{aligned}
$$

Elemen dasar dari proses membubut dapat diketahui atau dihitung dengan menggunakan rumus sebagai berikut:

1. Kecepatan potong, $V=\frac{\pi \cdot d \cdot n}{1000}\left(\frac{m}{\min }\right)$

Dimana, $d=$ diameter rata-rata

$$
=(\mathrm{do}+\mathrm{dm}) / 2(\mathrm{~mm})
$$

2. Kecepatan makan, $V_{f}=f . n(m m / m i n)$

3. Waktu pemotongan, $t_{c}=I_{t} / V_{f}$

Dalam penelitian ini hasil kekasaran permukaan dan ketelitian dimensi dipengaruhi oleh kondisi pemotongan pada mesin bubut, kondisi pemotongan tersebut digambarkan oleh beberapa variabel sebagai berikut [4]:

a. Kecepatan potong, adalah kecepatan benda kerja melintasi pahat.

b. Gerak makan (feed), adalah jarak yang ditempuh pahat sepanjang benda kerja pada suatu putaran poros utama mesin perkakas (spindle)

c. Kedalaman potong (a), adalah nilai kedalaman pemotongan yang dilakujan perkakas dan besarnya dinyatakan dalam milimeter.

\subsection{Komponen Pengerjaan Pemesinan Mesin Bubut}

Mesin bubut mencakup segala mesin perkakas yang memproduksi bentuk silindris. Akan tetapi dapat juga dipakai untuk beberapa kepentingan lain [5].

Mesin bubut yang digunakan untuk memotong benda kerja menggunakan mesin bubut konvensional dengan putaran maksimum sampai 2000 RPM, konstruksi mesin bubut tersebut pada umumnya memiliki Ekor tetap, sekerup pengarah, batang hantaran, perletakan majemuk, sadel pahat, dan apron.

\section{Sifat material pahat}

Sifat-sifat material dari pahat yang perlu dipertimbangkan adalah kekerasan, keuletan, ketahanan beban kejut termal, sifat adhesi yang rendah, dan daya larut elemtn/ komponen material pahat [4].

Bahan yang dipakai untuk pahat adalah Cubic Boron Nitride ( $C B N)$, yaitu bahan pahat yang sesuai pada pemesinan berbagai baja dalam keadaan dikeraskan (hardenned steel), besi tuang, HSS maupun karbida semen [8]

\section{Sifat material benda kerja}

Material benda kerja menjadi salah satu faktor yang sangat dominan yang dapat mempengaruhi timbulnya temperatur pada proses pemotongan. Benda kerja AISI 01 mempunyai karakteristik kemampu mesinan yang baik, stabilitas dimensi yang baik pada saat hardening, dan mempunyai kombinasi yang baik antara kekerasan permukaan dan ketangguhan sesudah hardening dan tempering [6]. 


\section{Definisi Alat Ukur}

Dalam penelitian ini untuk melihat nilai kekasaran permukaan dan kestabilan dimensi oleh karena itu perlu diketahui karakteristik dari alat ukur kekasaran permukaan dan dimensi yang dipakai, secara umum bagian-bagian utama yang membentuk sebuah alat ukur adalah [4]:

1. Sensor: bagian penghubung antara alat ukur dan benda ukur.

2. Pengubah: bagian untuk mengubah/ memperjelas isyarat dari sensor dan meneruskan kebagian penunjuk.

3. Penunjuk/pencatat: bagian penunjukkan besaran harga hasil pengukuran.

\section{Kekasaran Permukaan $\left(R_{i}\right)$}

Permukaan adalah batas yang memisahkan benda padat dengan sekelilingnya. Kekasaran permukaan adalah bentuk geometri permukaan suatu benda $[1,4]$.

Hubungan antara nilai kekasaran permukaan dengan radius mata potong pahat $(r)$ adalah: $R_{i}=\frac{f^{2}}{32 r}(\mu m)$, dimana: $\{f=$ Feed rate $(\mathrm{mm} / \mathrm{rev})\}[1]$.

\section{Dimensi dan Toleransi}

Dalam penelitian ini hasil yang diinginkan adalah tingkat ketilitian dimensi yang tinggi, maka tingkat ketelitian perlu ditambahkan bilangan toleransi pada dimensi. Toleransi adalah besar variasi yang diperkenankan pada suatu bagian tertentu atau merupakan variasi total yang diizinkan pada dimensi tertentu [5].

DImensi dengan toleransi yang ketat berarti bahwa bagian suku cadang tersebut harus pas betul dengan bagian lainnya.

\section{Perlakuan Panas pada Benda Kerja}

Dalam penelitian ini diperlukan perlakuan panas (heat treatment) yang merupakan salah satu proses yang diperlukan untuk merubah sifat-sifat material sebelum proses finishing. Perlakuan panas adalah suatu proses pemanasan dan pendinginan logam dalam keadaan padat untuk mengubah sifatsifat fisis logam tersebut [5].

Tahapan dari heat treatment yang dilakukan pada baja AISI 01 adalah sebagai berikut: Austenizing $\rightarrow$ Hardening $\rightarrow$ Quenching $\rightarrow$ Tempering $\rightarrow$ Freely by air.

\subsection{Dry Machining}

Proses dry machining adalah proses yang dilakukan pada proses pemotongan logam tanpa menggunakan fluida pendingin/ cutting fluid $[3,9]$.

Proses dry machining sangat tepat dilakukan pada baja yang sudah dikeraskan atau pembubutan material yang dikeraskan (hard turning) dengan tingkat kekerasan dari 45-70 HRC, hard turning biasa dilakukan pada proses finishing karena proses ini barada di akhir pembuatan suatu produk jadi.

Performansi yang dihasilkan dari proses hard turning apabila dilakukan pada mesin yang mempunyai konfigurasi yang baik maka akan menghasilkan penyelesaian permukaan di bawah $0.0003 \mathrm{~mm}$, nilai kesilindrisan pada $0.00025 \mathrm{~mm}$, dan pengaturan dimensi sekurang-kurangnya [12].

\section{METODOLOGI PENELITIAN}

\subsection{Diagram ALir Prosedur Penelitian}

Adapun diagram alir dari eksperimen ini adalah sebagai berikut:

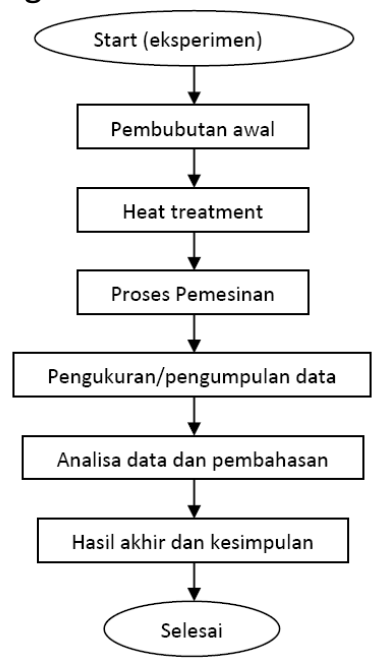


Penjelasan dari diagram alir di atas adalah:

- Pembubutan awal: pembubutan lunak, untuk menyeragamkan dimensi benda kerja.

- Heat treatment: untuk mencapai kekerasan tertentu dari benda karja.

- Dry machining: Proses eksperimen

- Pengukuran Kekasaran permukaan dan diameter benda kerja hasil eksperimen.

\subsection{Benda Kerja}

Benda uji yang digunakan adalah AISI 01. Dimana AISI 01 termasuk ke dalam golongan tool steel yaitu oil-hardening tool steels [6,13]. Benda kerja berbentuk solid bar dengan diameter $32 \mathrm{~mm}$ dan panjang 100 $\mathrm{mm}$.

\subsection{Pahat}

Pahat yang digunakan adalah Cubic Boron Nitride (CBN) yang mempunyai bentuk geometri sudut 80 derajat dan preparasi tepi merupakan gabungan antara chamfer dan honed. Radius mata pahat yang digunakan adalah $0.8 \mathrm{~mm}$.

Sifat-sifat material pahat adalah sebagai berikut:

$\begin{array}{ll}\text { Kekerasan } & : 2700 \mathrm{HV} \\ \text { Keuletan } & : 5.0 \mathrm{MPa}\end{array}$

Kekuatan Flexural : 120-130 MPa

Tool holder yang digunakan untuk uji pemotongan adalah PCLNR20K jenis righhanded dengan side cutting edge angle $5^{\circ}$. Back rake angle $-5^{\circ}$ dan side rake angle $-5^{\circ}$.

\subsection{Proses Perlakuan Panas}

Pada perlakuan panas (Heat treatment) menggunakan tungku pembakaran dengan spesifikasi sebagai berikut:

\section{Merk: Hofmann}

Buatan: Austria

Type: K1

No Pabrikasi/Thn Pembuatan: 99252/1999

Daya/Amp./Volt/Freq.: 6.6 W/9.5 A/400 V/50

$\mathrm{Hz}$

Suhu maksimum: $1200{ }^{\circ} \mathrm{C}$
Dengan tujuan untuk mendapatkan kekerasan yang tinggi maka dilakukan proses heat treatmant pada baja AISI 01 dengan tahapan proses sebagai berikut:

Austenizing (Pre-heating) $\rightarrow$ Hardening $\rightarrow$ Quenching $\rightarrow$ Tempering $\rightarrow$ Freely by air.

Untuk proses perlakuan panas pada baja AISI 01 di atas dapat digambarkan pada diagram di bawah ini.

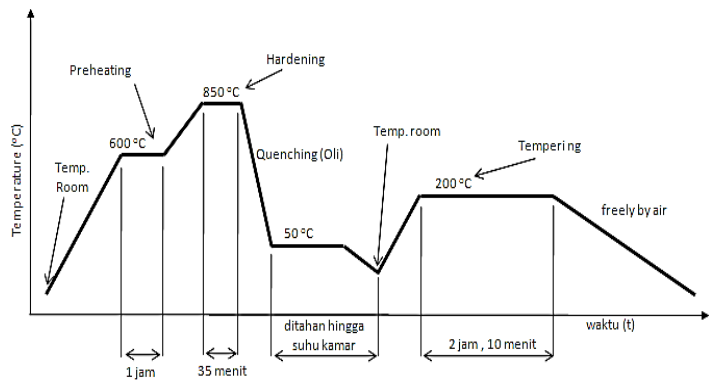

Berdasarkan proses perlakuan panas dengan tujuan pengerasan yang sudah dilakukan di atas, kemudian benda kerja dapat diuji kekerasan untuk mendapatkan nilai kekerasan.

Mesin uji kekerasan yang dipakai untuk mencari nilai kekerasan HRC adalah sebagai berikut:

Merk : WOLPERT Testor Amster/Germany

Type : Testor HT 2002

Kapasitas: Beban 150 kgf (1471 N)

Untuk mengidentifikasi benda kerja maka dilakukan stamping dengan penomoran. Dari jumlah benda kerja sebanyak 8 (delapan) buah maka didapat nilai kekerasan rata-rata sebesar $58.738 \mathrm{HRC}$.

\subsection{Variabel proses pemesinan}

Variabel yang diinginkan adalah:

- Kecepatan potong (V): $200 \mathrm{~mm} / \mathrm{min}$

- Kedalaman potong (a): $0.15 \mathrm{~mm}$

- Kecepatan Spindel (n): 2000 RPM

- Gerak Makan (f): 0.072 mm/put

\subsection{Rancangan Penelitian}

Benda kerja dengan diameter $32 \mathrm{~mm}$ akan dibubut sepanjang $50 \mathrm{~m}$ sebanyak 
delapan (8) buah.

llustrasi pemotongan adalah sebagai berikut:

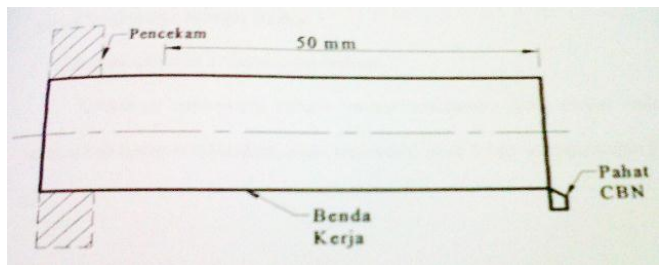

Mesin bubut yang digunakan adalah dengan spesifikasi sebagai berikut:

Type: DP $132 \mathrm{~s} / 4 \mathrm{~T}$

Merk: Voest - ALPINE (Steinel) WEILER

Buatan AUstria

Putaran motor: 2000 RPM

Sesudah di bubut benda kerja akan dilakukan proses pengukuran kekasaran permukaan dan pengukuran diameter.

\subsection{Pengukuran Kekasaran Permukaan}

Alat pengukur kekasaran permukaan menggunakan Rauchness Tester merk Mitutoyo SJ-201 dengan trace of length 5.6 $\mathrm{mm}$, cut of length $0.8 \mathrm{~mm}$.

Kekasaran permukaan dengan satuan mikrometer $(\mu \mathrm{m})$ diukur sebanyak 3 titik setiap $5 \mathrm{~mm}$ mulai dari pertama kali ujung pembubutan, yaitu mulai dari jarak $5 \mathrm{~mm}$ sampai dengan jarak $15 \mathrm{~mm}$, sehingga jumlah titik pengukuran sebanyak $3 \times 24=72$ titik.

Tabel Hasil pengukuran kekasaran permukaan adalah sebagai berikut:

\begin{tabular}{|c|c|c|}
\hline $\begin{array}{c}\text { rata-rata } \mathrm{Ra}_{1} \\
\text { (jarak } 5 \mathrm{~mm} \text { ) }\end{array}$ & $\begin{array}{c}\text { rata-rata } \mathrm{Ra}_{2} \\
\text { (jarak } 5-10 \mathrm{~mm} \text { ) }\end{array}$ & $\begin{array}{c}\text { rata-rata } \mathrm{Ra}_{3} \\
\text { (jarak } 10-15 \mathrm{~mm} \text { ) }\end{array}$ \\
\hline $0.605 \mu \mathrm{m}$ & $0.573 \mu \mathrm{m}$ & $0.548 \mu \mathrm{m}$ \\
\hline
\end{tabular}

Didapat nilai rata-rata kekasaran permukaan sebesar $0.575 \mu \mathrm{m}$.

\subsection{Pengukuran Diameter rata-rata}

Diameter benda kerja diukur dengan menggunakan sigmat tiap jarak $2 \mathrm{~mm}$ mulai dari ujung pembubutan sampai jarak $46 \mathrm{~mm}$. Lihat ilustrasi pengukuran berikut:

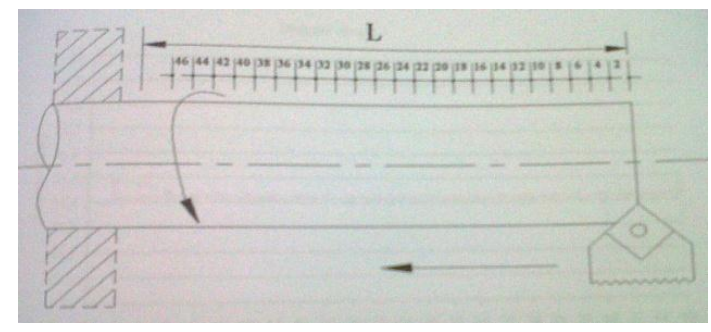

Pengukuran dilakukan sebanyak 115 titik pada satu sampel dan pada jumlah 8 sampel didapat jumlah data pengukuran sebanyak 920 data diameter, dengan nilai diameter pengukuran $\left(d_{p}\right)$ adalah $31.68 \mathrm{~mm}$

Kemudian dihasilkan selisih antara diameter pengukuran $\left(d_{p}\right)$ dari benda dengan diameter awal $\left(d_{0}\right)$ dari benda dengan rumusan: $\Delta d=d_{0}-d_{p}$, dan nilai selisih tersebut menjadi nilai penyimpangan dimensi rata-rata benda dengan nilai maksimum adalah $0.029 \mathrm{~mm}$ dan nilai minimum 0.013 $\mathrm{mm}$.

\section{PENGOLAHAN DATA DAN PEMBA- HASAN}

Kemudian dihitung nilai teoritis dari kekasaran permukaan, keakurasian dimensi dan hubungan antara kekakuan mesin dan kekasaran permukaan sebagai berikut:

\subsection{Perhitungan Kekasaran Permukaan}

Dengan memasukkan nilai variabelvariabel pemotongan didapat elemen-elemen dasar dari proses membubut antara lain:

Menghitung diameter rata-rata:

$$
\begin{gathered}
d_{\text {rata-rata }}=\frac{d o-d m}{2}=\frac{(32-31.68) \mathrm{mm}}{2} \\
=31.84
\end{gathered}
$$

Kecepatan potong (V):

$$
\begin{aligned}
V= & \frac{\pi \cdot d \cdot n}{1000}=\frac{\pi \times 31.84 \mathrm{~mm} \times 2000 \mathrm{rpm}}{1000} \\
& =199.9 \mathrm{~m} / \mathrm{min} \approx 200 \mathrm{~m} / \mathrm{min}
\end{aligned}
$$




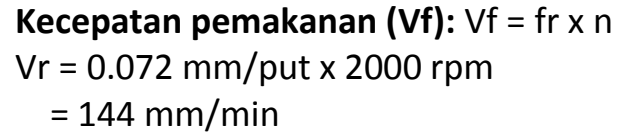

Waktu pemotongan: $\mathrm{tc}=\mathrm{It} / \mathrm{Vf}$

$$
\begin{aligned}
& =(50 \mathrm{~mm}) /(144 \mathrm{~mm} / \mathrm{min}) \\
& =0.347 \mathrm{menit}
\end{aligned}
$$

$\mathrm{fr}=$ Gerak pemakanan ( $\mathrm{mm} /$ put)

$\mathrm{It}=$ Panjang benda kerja $(\mathrm{mm})$

$\mathrm{n}=$ putaran spindel (rpm)

$r=$ radius mata potong $(\mathrm{mm})$

Nilai kekasaran permukaan ideal (Ri):

$$
R i=\frac{f r^{2}}{32 r}=\frac{0.072 \mathrm{~mm} / \mathrm{put}^{2}}{32 \times 0.8 \mathrm{~mm}}=0.2025 \mu \mathrm{m}
$$

Nilai di atas adalah nilai teoritis yang didapat dengan memasukkan variabel pemotongan.

\subsection{Standar Deviasi}

Standar deviasi digunakan untuk mengukur tingkat keakurasian proses dan tingkat penyimpangan atau variasi yang terjadi pada pengukuran diameter produk

$$
S=\sqrt{\frac{\sum\left(X_{i}-\bar{X}\right)^{2}}{n-1}}
$$

contoh pada sampel nomor 1 dengan nilai selisih nilai diameter benda $(\mathrm{Xi}-\mathrm{X})^{2}=2.6 \times 10^{-3}$ $\mathrm{mm}$ dan jumlah pengukuran sebanyak 5 pada satu sampel maka:

$S=\sqrt{\frac{2.6 \times 10^{-3}}{5-1}}=0.025$ maka nilai rata-rata $S$ pada keseluruhan sampel (8 sampel) adalah: 0.011 .

\subsection{Kekakuan Mesin (Cr)}

Nilai rata-rata kekasaran permukaan (Ra) adalah $0.576 \mu \mathrm{m}$, maka

$$
C_{r}=\frac{R_{a} \cdot 8 \cdot r}{f_{r}{ }^{2}}=\frac{0.576 \times 8 \times 0.8}{0.072^{2}}=711
$$

Nilai konstanta $\mathrm{Cr}$ adalah 711 merupakan sistem yang kaku karena untuk kekakuan mesin mempunyai kekakuan terbaik dibawah harga Cr 2000.

\subsection{Hubungan $\mathrm{Cr}$ dengan $\mathrm{Ra}$}

Semakin kecil nilai kekasaran permukaan (Ra) maka semakin besar nilai kekakuan mesin, dan nilai gerak pemakanan (fr) merupakan nilai yang diharuskan jika ingin mendapatkan kekasaran permukaan yang rendah.

\subsection{Hubungan Ra dengan $\Delta d$}

Nilai kekasaran permukaan (Ra) menurun dengan bertambahnya panjang pemakanan sepanjang benda kerja dengan penjang pemotongan $46 \mathrm{~mm}$.

Hal ini disebabkan oleh adanya defleksi

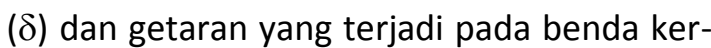
ja yang diakibatkan gaya potong dari pahat, semakin panjang benda maka defleksi dan getaran pada ujung benda kerja akan semakin besar, sehingga getaran yang timbul akan besar pada awal panjang pemakanan.

\subsection{Perbandingan $\boldsymbol{R i}$ dan $\boldsymbol{R a}$}

Perbandingan kekasaran permukaan teoritis (Ri) dan kekasaran permukaan eksperimen ( $\mathrm{Ra}$ ) terdapat adanya perbedaan, hal ini disebabkan oleh adanya pengaruh temperatur pemotongan yang tinggi, dan getaran eksitasi mandiri (chatter).

Harga parameter kekasaran permukaan eksperimen ( $\mathrm{Ra}$ ) diatas merupakan suatu bentuk kekasaran yang halus, dapat dibandingkan pada tabel berikut [17]:

\begin{tabular}{|l|l|l|}
\hline $\begin{array}{c}\text { ISO } \\
\text { Number }\end{array}$ & $\begin{array}{c}\text { Mean } \\
\text { Raughness } \\
(\text { Ra } ; \mu \mathrm{m})\end{array}$ & \multicolumn{1}{|c|}{ Keterangan } \\
\hline N12 & 50.0 & - Sangat Kasar \\
\hline N11 & 25.0 & \\
\hline N10 & 12.5 & - Kasar \\
\hline N9 & 6.3 & \\
\hline N8 & 3.2 & - Normal \\
\hline N7 & 1.6 & \\
\hline N6 & 0.8 & \\
\hline N5 & 0.4 & - Halus \\
\hline N4 & 0.2 & \\
\hline N3 & 0.1 & - Sangat halus \\
\hline
\end{tabular}




\subsection{Keakurasian Dimensi Benda kerja}

Toleransi dan keakurasian dimensi diameter benda kerja dengan menggunakan mesin bubut konvensional adalah sebagai berikut:

- $\quad$ Nilai selisih diameter terjadi lebih besar pada posisi pengukuran jarak $2.4 \mathrm{~mm}$ dan $6 \mathrm{~mm}$ karena pengaruh getaran dan defleksi yang besar.

- $\quad$ Nilai selisih diameter rata-rata $(\Delta \mathrm{d})$ yang maksimum adalah $0.029 \mathrm{~mm}$ dan minimum adalah $-0.013 \mathrm{~mm}$, besar kecilnya nilai $\Delta$ d diukur dari jarak nilai standar 0 .

- $\quad$ Nilai positif $(+)$ berarti nilai selisih $\Delta d$ benda kerja lebih besar dan nilai negatif (-) berarti nilai $\Delta$ d lebih kecil, yang dipengaruhi kedalaman potong (a), getaran dan defleksi benda kerja.

\section{KESIMPULAN DAN SARAN}

- Dry machining dapat dilakukan pada proses pemesinan yang memerlukan tingkat kekasaran permukaan yang rendah dan tingkat keakurasian dimensi yang tinggi.

- Nilai kekeasaran permukaan eksperimen adalah $0.576 \mu \mathrm{m}$ dan keakurasian dimensi berdasarkan nilai standar deviasi (S) adalah 0.011.

- Nilai kekasaran permukaan eksperimen yang didapat adalah tingkat permukaan dengan keterangan halus atau sama dengan ISO number N5.

- Agar data lebih teliti sebelum eksperimen sebaiknya mesin dicek kepresisiannya.

- Perlu dilakukan penelitian untuk mencari hubungan antara kekasaran permukaan, keakurasian dimensi dan kekakuan mesin, serta ditentukan hubungan antara variabelvariabel pemotongan dan pengaruhnya terhadap kekasaran permukaan.

\section{DAFTAR PUSTAKA}

[1] ST., MT, Wiyono Slamet. 2005. Proposal penelitian "Pengembangan model empiris untuk memprediksi kekasaran permukaan pada finish hard turning". Universitas Sultan Ageng Tirtayasa, Jurusan Teknik Mesin.

[2] Wiyono Slamet, AS Danardono, Kiswanto Gandjar. 2005. Pengaruh parameter pemesinan terhadap kualitas permukaan baja DF-3 (AISI O1) yang dikeraskan. JURNAL TEKNOLOGI Universitas Indonesia, Edisi No.3, tahun XIX, September, 179-265.

[3] Shefelbine Wendy and Dornfeld A. 2004. David. The Effect of Dry machining on burr size, the Journal of Consortium and Edge Finishing. University of California, Berkeley.

[4] Hartanto Agus. Tugas Akhir. 2003. Analisa pengujian umur pahat dan kekasaran permukaan pada benda kerja ST 42. Universitas Mercubuana, Jurusan Teknik Mesin.s

[5] Amstead, B.H. 1990. Teknologi Mekanik, Jakarta. Erlangga.

[6] Corus Engineering Steels. Cold work tool steel to AISI 01.

http://www.corusnz.com/downloads/To olsteel_AISIO1.pdf\#search='AISI\%2001'

[7] Ozel Tuqrul and Karpat Yigit. 2004. Predictive modeling of surface roughness and tool wear in hard turning using regression and nural networks. Int., Journal of machine toolds and manufacture 45 (2005) 467-479. University of New Jersey.

[8] http://www.mothersontools.com/cbn_h 
ard_steel_adv.thm

[9] Feng, C, Shaw. Hattor, Mitsuro. Cost and Process Information Modelling for Dry Machining. Manufacturing Engineering Laboratory NIST, DoC and AIST, MITI.

[10] Graham Don, Huddle Dave and McNamara Dennis. 2005. Feature Article - Machining Dry is Worth A Try. Fro MMS Online ${ }^{\mathrm{TM}}$.

[11] Ozel Tuqrul, Hsu Kong-Tsu, and Zeren Erol. 2005. Effect of cutting edge geometry, workpiece hardness, feed rate and cutting speed on roughness and forces in finish turning of hardened AISI H13 steel. Intl J Adv Manuf Technol page 25:262-269. University of New Jersey.

[12] Soroka, P, Daniel. 2003. Hard Turning and the machine tool, Hardinge Inc.

[13] Metal Handbook. Heat treating cleaning and finishing. Eighth edition. Volume 2. American Society for Metal (ASM).

[14] Web master www.kyocera.com

[15] http://global.kyocera.com/prdct/tool/ce ratip/repert/CBN.html

[16] Ariani Wahyu Dorothea. 2004. Pengendalian kualistas statistik (Pendekatan kuantitatif manajemen kualitas). Penerbit ANDI Yogyakarta.

[17] Rochim, T. 1993. Teori dan Teknologi Proses Pemesinan, Laboratorium Teknik Pro-duksi dan Metrologi Industri, Jurusan Teknik Mesin, FTI, ITB, Bandung. 


\title{
SISTEM PENGENDALI KONVEYOR BELT PADA PT. XYZ TANGERANG
}

\author{
Sumardi Sadi \\ Universitas Muhammadiyah Tangerang \\ E-mail: mardiesadi99@gmail.com
}

\begin{abstract}
ABSTRAK
Sistem kendali conveyor belt pada PT. XYZ merupakan alat untuk memindahkan suatu produk yang dihasilkan dari bagian produksi ke gudang penyimpanan. Sistem konveyor banyak digunakan diberbagai macam industri, baik industry kecil maupun besar, yang tentetunya konveyor tersebut sebagai pengangkut dan pemindah barang pada suatu proses produksi. Dalam penelitian ini metode yang di gunakan adalah dengan cara mengamati dan mempelajari sistem kontrol dari conveyor belt tersebut beserta alatnya berupa motor, gearbox dan inverter yang diatur di dalam panel box untuk membawa box produk yang berisi produk dari suatu proses produksi. Dari penelitian ini diperoleh kesimpulan dalam 1 hari conveyor belt tersebut dapat membawa kurang lebih 600 Dus (tempat produk) pada speed inverter 28-32 Rpm yang berisi hasil produksi dari bagian produksi ke gudang, dibandingkan dengan membawa manual yang membutuhkan waktu yang lama dan tenaga yang kuat. Dengan adanya konveyor, membuat perusahaan menjadi efektif dan efisien dalam membawa dan menata hasil produksi.
\end{abstract}

Kata Kunci: Conveyor, Sistem Kontrol, Motor, Gear Box, Panel Box.

\section{PENDAHULUAN}

\subsection{LATAR BELAKANG MASALAH}

Seiring dengan perkembangan zaman maka kemajuan teknologi juga berkembang dengan pesat sehingga persaingan didalam dunia industri sendiri menuntut agar adanya peningkatan ketersediaan peralatan guna mendukung proses produksi suatu perusahaan. Dengan meningkatnya kebutuhan akan penggunaan teknologi guna meningkatkan produktivitas maka kebutuhan perawatan semakin besar juga.

Ada banyak faktor yang dapat mempengaruhi produksi salah satunya dengan sistem produksi yang handal, dalam hal ini adalah mesin serta komponen lainnya dapat beroperasi tanpa mengalami kerusakan pada saat proses produksi berlangsung. Secara alamiah tidak ada barang yang dibuat oleh manusia yang tidak dapat rusak akan tetapi usia pemakaian dapat diperpanjang dengan melakukan perbaikan berkala dengan suatu aktivitas yang dikenal sebagai pemeliharaan (maintenance).

Oleh karena itu teknologi otomasi industri sangat pesat dengan semakin banyak industri yang menggunakan sistem otomasi dalam menjalankan proses-proses produksinya. Sistem otomasi pada conveyor belt tersebut masih penggunaan sistem kendali konvensional yang terdiri dari beberapa komponen yaitu relai, kontaktor, dan kontraktor magnetik, hanya menambahkan alat yang bernama inverter di dalamya penggunaan kontrolnya. 


\subsection{IDENTIFIKASI MASALAH}

Berdasarkan latar belakang diatas, penggunaan sistem kontrol conveyor belt pada dunia industri sangat berpengaruh besar. Sehingga dapat di rumuskan permasalahan yang akan dibahas dalam penelitian ini yaitu bagaimana sistem otomasi kontrol conveyor belt di dunia industri agar dapat menghasilkan kerja conveyor belt yang maksimal.

\subsection{BATASAN MASALAH}

Agar permasalahan yang akan dibahas tidak semakin melebar serta berjalan dengan baik sesuai dengan alurnya maka dalam penelitian ini diperlukan adanya batasan-batasan masalah. Batasan-batasan masalah yang digunakan anatara lain: Memaparkan sistem otomasi kontrol pada conveyor belt.

\subsection{TUJUAN DAN MANFAAT PENULISAN}

Tujuan dari Penelitian ini adalah untuk Mendapatkan pengetahuan tentang ilmu di lingkungan kerja yang sebenarnya, mengetahui sistem kontrol otomasi conveyor belt dengan inverter dan mengetahui dan mempelajari cara pemasangan conveyor belt dengan inverter.

\subsection{METODE PENELITIAN}

Dalam penelitian ini, menggunakan beberapa metode, antara lain:

1. Metode observasi pengamatan, adalah metode pengumpulan data dengan melakukan pengamatan-pengamatan secara langsung terhadap obyek yang akan dilaporkan dan mencatat segala yang berhubungan dengan pembuatan laporan.

2. Metode wawancara, adalah metode pengumpulan data dengan melakukan tanya jawab secara langsung, guna memperoleh informasi dan data yang dibutuhkan .

Metode study literatur, adalah metode pengumpulan data dengan cara membaca dan mempelajari buku-buku referensi maupun pencarian di situs-situs internet yang berhubungan dengan pembuatan laporan.

\section{LANDASAN TEORI}

\subsection{MOTOR LISTRIK 3 FASA}

Motor induksi tiga fasa merupakan motor elektrik yang paling banyak digunakan dalam dunia industri. Salah satu kelemahan motor induksi yaitu memiliki beberapa karakteristik parameter yang tidak linier, terutama resistansi rotor yang memiliki nilai yang bervariasi untuk kondisi operasi yang berbeda, sehingga tidak dapat mempertahankan kecepatannya secara konstan bila terjadi perubahan beban. Oleh karena itu untuk mendapatkan kecepatan yang konstan dan peformansi sistem yang lebih baik terhadap perubahan beban dibutuhkan suatu pengontrol.

Motor induksi 3 fasa adalah alat penggerak yang paling banyak digunakan dalam dunia industri. Hal ini dikarenakan motor induksi mempunyai konstruksi yang sederhana, kokoh, harganya relatif murah, serta perawatannya yang mudah, sehingga motor induksi mulai menggeser penggunaan motor DC pada industri. Motor induksi memiliki beberapa parameter yang bersifat non-linier, terutama resistansi rotor, yang memiliki nilai bervariasi untuk kondisi operasi yang berbeda. Hal ini yang menyebabkan pengaturan pada motor induksi lebih rumit dibandingkan dengan motor DC. Salah satu kelemahan dari motor induksi adalah tidak mampu mempertahankan kecepatannya dengan konstan bila terjadi perubahan beban. Apabila terjadi perubahan beban maka kecepatan motor induksi akan menurun. Untuk mendapatkan kecepatan konstan serta memperbaiki kinerja motor induksi terhadap perubahan beban, maka dibutuhkan suatu pengontrol.

Penggunaan motor induksi tiga fasa di beberapa industri membutuhkan performansi yang tinggi dari motor induksi untuk dapat 
mempertahankan kecepatannya walaupun terjadi perubahan beban. Salah satu contoh aplikasi motor induksi yaitu pada industri kertas. Pada industri kertas ini untuk menghasilkan produk dengan kualitas yang baik, dimana ketebalan kertas yang dihasilkan dapat merata membutuhkan ketelitian dan kecepatan yang konstan dari motor penggeraknya, sedangkan pada motor induksi yang digunakan dapat terjadi perubahan beban yang besar.

Beberapa penelitian pengaturan kecepatan motor induksi yang telah dilakukan antara lain oleh Brian Heber, Longya Xu dan Yifan Tang (1997) menggunakan kontroller logika fuzzy untuk memperbaiki performansi kontroller PID pada pengaturan kecepatan motor induksi. Demikian juga penelitian yang dilakukan oleh Mohammed dkk. (2000) mengembangkan kontroller fuzzy yang digunakan untuk menala parameter PI. Kontroller fuzzy juga dikembangkan pada penelitian yang dilakukan Chekkouri MR dkk. (2002) dan Lakhdar M \& Katia K (2004) dengan melengkapi mekanisme adaptasi pada kontroller fuzzy pada pengaturan motor induksi. Pada penelitian ini dirancang suatu pengaturan kecepatan motor induksi 3 fasa dengan menggunakan pengontrol adaptif fuzzy. Dengan adanya pengaturan kecepatan ini diharapkan kecepatan motor induksi dapat konstan sesuai yang diinginkan, walaupun mendapat perubahan beban, sehingga menghasilkan performansi motor induksi yang tinggi.

Motor induksi merupakan motor arus bolak balik (ac) yang paling luas penggunaannya. Penamaannya berasal dari kenyataan bahwa arus rotor motor ini bukan diperoleh dari sumber tertentu, tetapi merupakan arus yang terinduksi sebagai akibat adanya perbedaan relative antara putaran rotor dengan medan putar (rotating magnetic field) yang dihasilkan oleh arus stator.

Belitan stator yang dihubungkan dengan suatu sumber tegangan tiga fasa akan meng- hasilkan medan magnet yang berputar dengan kecepatan sinkron ( $n s=120 \mathrm{f} / 2 \mathrm{p}$ ). Medan putar pada stator tersebut akan memotong konduktor-konduktor pada rotor, sehingga terinduksi arus dan sesuai dengan Hukum Lentz, rotor pun akan ikut berputar mengikuti medan putar stator. Perbedaan putaran relative antara stator dan rotor disebut slip. Bertambahnya beban, akan memperbesar kopel motor, yang oleh karenanya akan memperbesar pula arus induksi pada rotor, sehingga slip antara medan putar stator dan putaran rotor pun akan bertambah besar. Jadi, bila beban motor bertambah, putaran rotor cenderung menurun. Dikenal dua tipe motor induksi yaitu motor induksi dengan rotor belitan dan rotor sangkar.

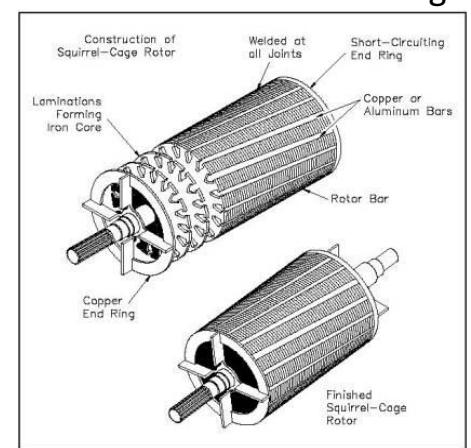

Gambar 2.1 Rotor Belitan

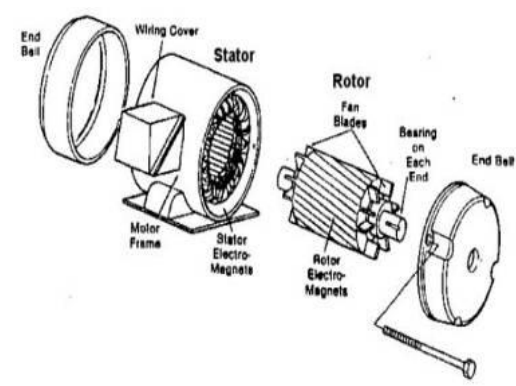

Gambar 2.2 Rotor Sangkar

Sebelum kita membahas bagaimana rotating magnetic field (medan putar) menyebabkan sebuah motor berputar, marilah kita tinjau bagaimana medan putar ini dihasilkan. Gambar berikut menunjukkan sebuah stator tiga fasa dengan suplai arus bolak balik tiga fasa pula. Belitan stator terhubung $\mathrm{Y}$ (wye). Dua belitan pada masing- 
masing fasa dililitkan dalam arah yang sama. Sepanjang waktu, medan magnet yang dihasilkan oleh setiap fasa akan tergantung kepada arus yang mengalir melalui fasa tersebut. Jika arus listrik yang melalui fasa tersebut adalah nol (zero), maka medan magnet yang dihasilkan akan nol pula. Jika arus mengalir dengan harga maksimum, maka medan magnet berada pada harga maksimum pula. Karena arus yang mengalir pada sistem tiga fasa mempunyai perbedaan $120^{\circ}$, maka medan magnet yang dihasilkan juga akan mempunyai perbedaan sudut sebesar $120^{\circ}$ pula. Ketiga medan magnet yang dihasilkan akan membentuk satu medan, yang akan beraksi terhadap rotor. Untuk motor induksi, sebuah medan magnet diinduksikan kepada rotor sesuai dengan po-laritas medan magnet pada stator. Karenanya, begitu medan magnet stator berputar, maka rotor juga berputar agar bersesuaian dengan medan magnet stator.

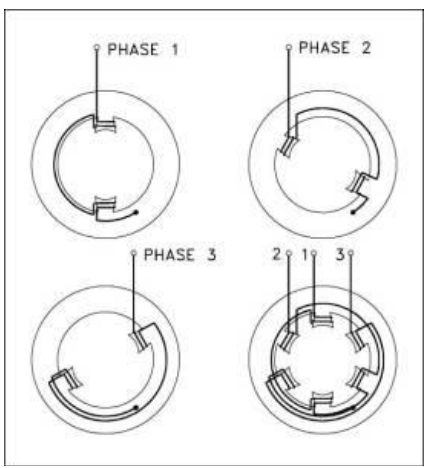

Gambar 2.3 Medan magnet stator 3 fasa

Pada sepanjang waktu, medan magnet dari masing-masing fasa bergabung untuk menghasilkan medan magnet yang posisinya bergeser hingga beberapa derajat. Pada akhir satu siklus arus bolak balik, medan magnet tersebut telah bergeser hingga $360^{\circ}$, atau satu putaran. Dan karena rotor juga mempunyai medan magnet berlawanan arah yang diinduksikan kepadanya, rotor juga akan berputar hingga satu putaran.

\subsection{Gear Box}

Gear box merupakan komponen meka- nikal yang menstranmisikan daya dan gerakan diantara sumbunya. Gear box juga dapat mengubah arah putaran dan mengubah gerakan rotasi menjadi gerakan linier. Fungsi gear box untuk merenduksi kecepatan pada conveyor sehingga putaran conveyor tetap stabil dan tidak terlalu cepat.

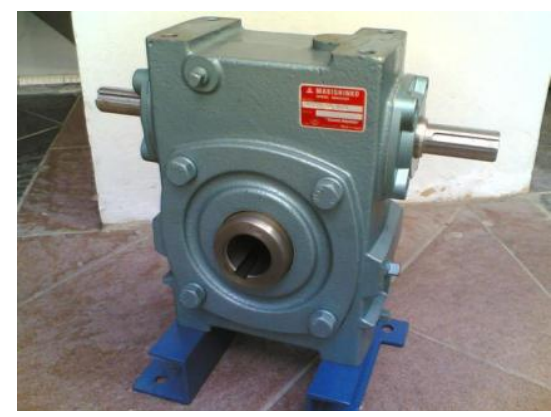

Gambar 2.4 Gear box

Prinsip Kerja Gearbox;

Putaran dari motor diteruskan ke input shaft (poros input) melalui hubungan antara clutch kopling, kemudian putaran diteruskan ke main shaft (poros utama), torsi momen yang ada di mainshaft diteruskan ke spindel mesin, karena adanya perbedaan rasio dan bentuk dari gigi-gigi tersebut sehingga rpm atau putaran spindel yang di keluarkan berbeda, tergantung dari rpm yang di inginkan. Berikut penjelasan beberapa part yang terdapat dalam gearbox:

\section{Input Shaft (Poros Input)}

Input shaft adalah komponen yang menerima momen output dari unit kopling, poros input juga befungsi untuk meneruskan putaran dari clutch kopling ke mainshaft (poros utama), sehingga putaran bisa di teruskan ke gear-gear. Input shaft juga sebagai poros dudukan bearing dan piston ring, selain itu berfungsi juga sebagai saluran oli untuk melumasi bagian dari pada input shaft tersebut.

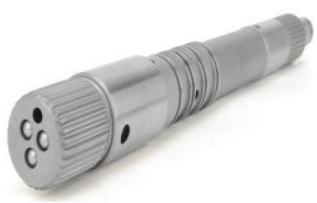

Gambar 2.5 Input Shaft (Poros Input) 


\section{Gear Shift Housing (Rumah Lever Pe- mindah Rpm)}

Gear shift housing adalah housing dari pada lever pemindah gigi yang berfungsi untuk mengatur ketepatan perpindahan gigi, apabila gigi sudah dipindahkan maka lever akan terkunci sehingga lever tidak bisa berpindah sendiri pada saat spindel sedang berputar.

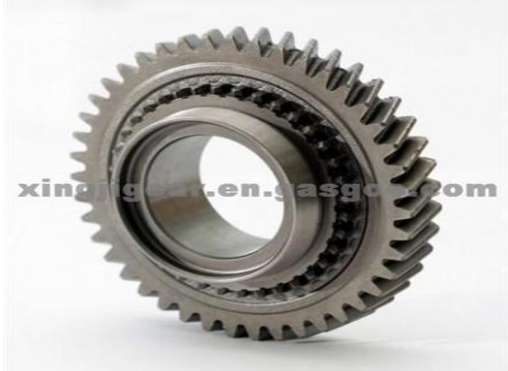

Gambar 2.6 Gear Shift Housing (Rumah Lever Pemindah RPM)

\section{Main Shaft (Poros Utama)}

Main shaft yang berfungsi sebagai tempat dudukan gear, sinchromest, bearing dan komponen-komponen lainnya. Main shaft juga berfungsi sebagai poros penerus putaran dari input shaft sehingga putaran dapat di teruskan ke spindel, main shaft juga berfungsi sebagai saluran tempat jalannya oli.

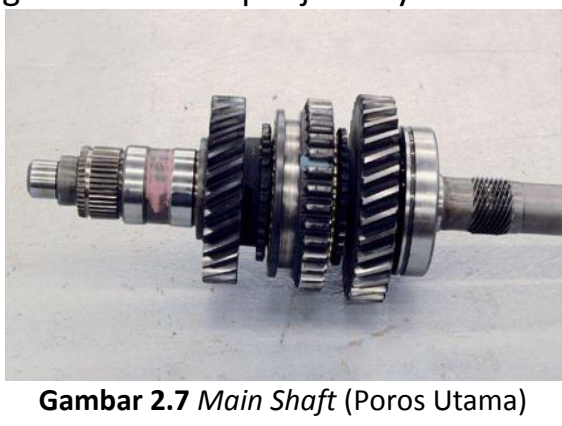

\section{Planetary Gear Section (Unit Gigi Plane- tari)}

Planetary adalah alat pengubah rpm di suatu range tertentu dimana rpm dapat di ubah sesuai dengan kebutuhan proses pengerjaan dan dapat pula mengubah arah putaran spindel.

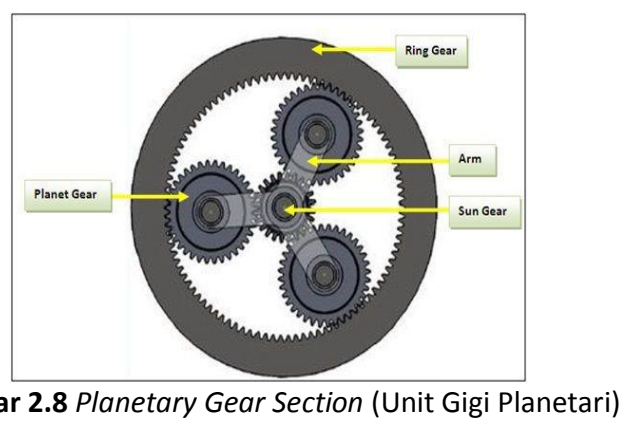

\section{Oil Pump Assy (Pompa Oli)}

Oil pump berfungsi untuk memompa dan memindahkan oli dari transmisi case (rumah transmisi) menuju ke sistem untuk dilakukan pe-lumasan terhadap komponen-komponen yang ada di dalam transmisi secara menyeluruh.

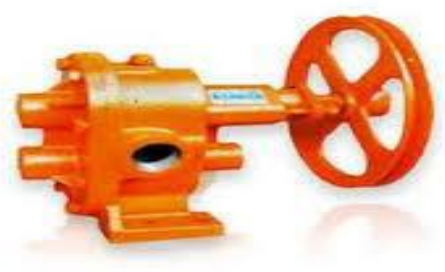

Gambar 2.9 Oil Pump Assy (Pompa Oli)

\section{Clucth Housing}

Clutch housing adalah rumah dari clucth kopling yang berfungsi sebagai pelindung clutch kopling, clutch housing juga berfungsi sebagai tempat dudukan dari pada oil pump dan input shaft.

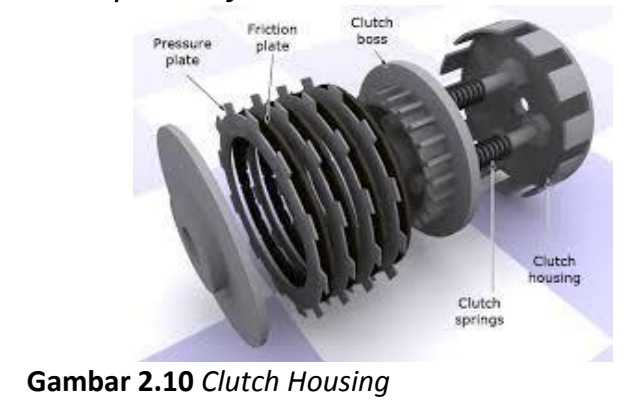

\section{Transmisi Gear (Roda Gigi Transmisi)}

Transmisi gear atau roda gigi transmisi berfungsi untuk mengubah input dari motor menjadi output gaya torsi yang meninggalkan transmisi sesuai dengan kebutuhan mesin. 


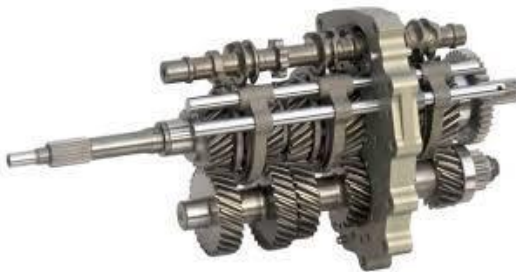

Gambar 2.11 Transmisi Gear (Roda Gigi Transmisi)

\section{Bearing}

Bearing berfungsi untuk menjaga kerenggangan dari pada shaft (poros), agar pada saat unit mulai bekerja komponen yang ada di dalam transmisi tidak terjadi kejutan, sehingga transmisi bisa bekerja dengan smooth (halus).

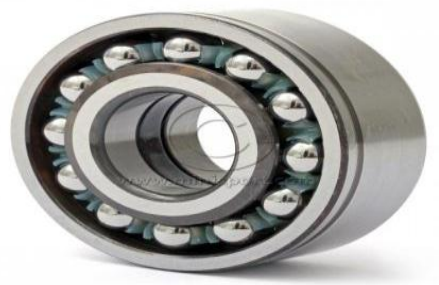

Gambar 2.11 Bearing

\section{Piston Ring (Ring Penyekat Oli)}

Piston ring berfungsi sebagai penyekat agar tidak terjadi kebocoran pada sistem pelumasan, piston ring juga berfungsi sebagai pengencang input shaft agar input shaft tidak renggang pada saat unit berjalan.

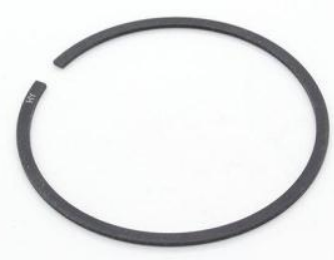

Gambar 2.12 Piston Ring (Ring Penyekat Oli)

\section{Sun Gear (Gigi Matahari)}

Sun gear berfungsi untuk meneruskan putaran ke planetary gear section. Sun gear berhubungan langsung dengan gear yang ada pada unit planetary yang berfungsi sebagai penerus putaran, momen dari transmisi.

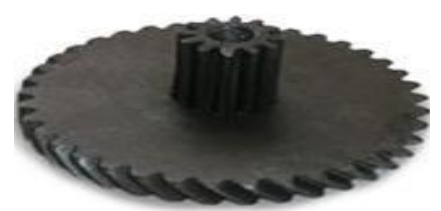

Gambar 2.13 Sun Gear (Gigi Matahari)

\section{Oil Filter (Filter Oli)}

Oil filter adalah komponen yang berfungsi untuk menyaring oli dari kotoran. Oli harus di saring, agar komponen transmisi tidak cepat aus yang disebabkan karena terjadinya gesekan antara komponen yang dapat menimbulkan geram-geram. Sehingga oli yang masuk ke sistem harus disaring dulu agar unit transmisi tetap baik.

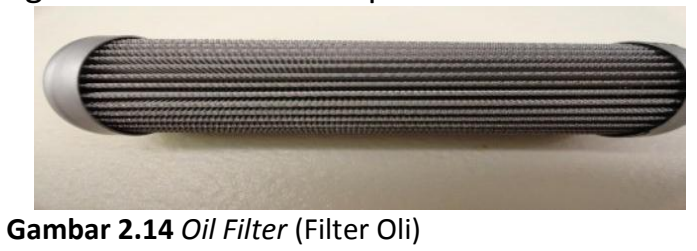

\section{Oil pipa (Pipa Oli)}

Oil pipa adalah pipa oli tipe batang, yang berfungsi sebagai saluran oli untuk menyalurkan oli dari transmisi case ke planetary gear section untuk dilakukan pelumasan terhadap unit planetary.

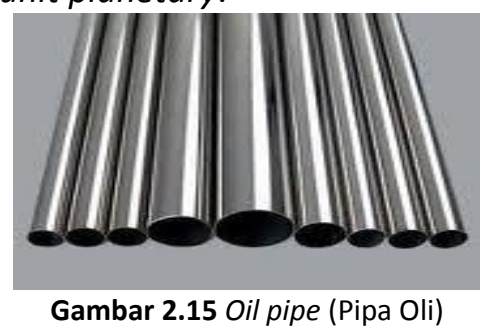

\subsection{Sensor Photodioda}

Photodioda merupakan sensor cahaya semikonduktor yang dapat mengubah besaran cahaya menjadi besaran listrik. Photodioda bekerja berdasarkan intensitas cahaya. Jika photodioda terkena cahaya maka photodioda bekerja seperti dioda pada umumnya tetapi jika tidak mendapat cahaya maka photodioda akan berperan seperti resistor dengan nilai tahanan yang besar sehingga arus listrik tidak dapat mengalir. 

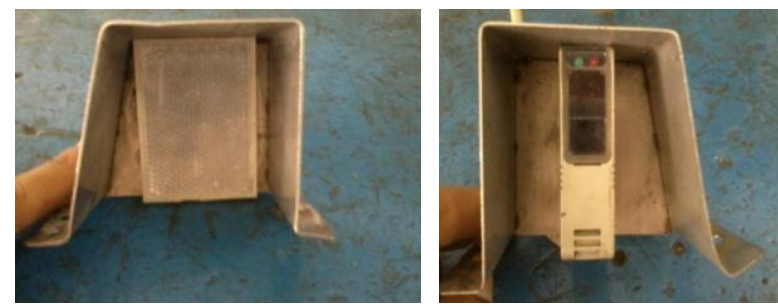

Gambar 2.16 Sensor Photodioda

\subsection{SISTEM KONTROL YANG BERADA DI DALAM PANEL BOX}

Dalam berjalannya sebuah conveyor selain di butuhkan motor dan gear box, conveyor juga di gerakkan oleh sistem kontrol yang berada di panel box. Di dalam panel tersebut banyak peralatan listrik yang berpengaruh besar dalam bekerjanya conveyor, antara lain:

\section{MCCB (Moulded Case Circuit Breaker)}

MCCB adalah Circuit Breaker pembatas arus apabila terdapat arus beban yg melebihi batas-batasnya. MCCB ini dipakai hampir sama dgn MCB tetapi dgn batas arus beban yg lebih besar dari 100 Ampere sampai dgn 1600 Ampere.

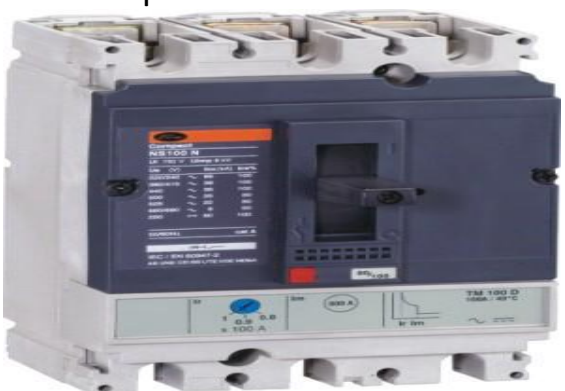

Gambar 2.17 MCCB (Moulded Case Circuit Breaker)

Dalam memilih circuit breaker hal-hal yang harus dipertimbangkan adalah:

- Karakteristik dari sistem dimana circuit breaker tersebut dipasang.

- Kebutuhan akan kontinuitas pelayanan sumber daya listrik.

- Aturan-aturan dan standar proteksi yang berlaku.
Karakteristik sistem:

1. Sistem tegangan

Tegangan operasional dari circuit breaker harus lebih besar atau minimum sama dengan tegangan sistem.

2. Frekuensi sistem

Frekuensi pengenal dari circuit breaker harus sesuai dengan frekuensi sistem. Circuit breaker Merlin Gerin dapat beroperasi pada frekuensi 50 atau 60 $\mathrm{Hz}$.

3. Arus pengenal

Arus pengenal dari circuit breaker harus disesuaikan dengan besarnya arus beban yang dilewatkan oleh kabel, dan harus lebih kecil dari arus ambang yang diijinkan lewat pada kabel.

4. Kapasitas pemutusan

Kapasitas pemutusan dari circuit breaker harus paling sedikit sama dengan arus hubung singkat prospektif yang mungkin akan terjadi pada suatu titik instalasi dimana circuit breaker tersebut dipasang.

5. Jumlah pole dari circuit breaker .

6. Jumlah pole dari circuit breaker sangat tergantung kepada sistem pembumian dari sistem.

Kebutuhan kontinuitas sumber daya tergantung dari kebutuhan tingkat kontinuitas pelayanan sumber daya listrik, dalam memilih circuit breaker harus diperhatikan:

1. Diskriminasi total dari dua circuit breaker yang ditempatkan secara seri.

2. Diskriminasi terbatas (sebagian), diskriminasi hanya dijamin sampai tingkat arus gangguan tertentu.

\section{Kontaktor (Magnetik Contactor)}

Kontaktor (Magnetik Contactor) yaitu peralatan listrik yang bekerja berdasarkan prinsip induksi elektromagnetik. Pada kontaktor terdapat sebuah belitan yang mana bila dialiri arus listrik akan timbul medan magnet pada inti besinya, yang akan membuat 
kontaknya tertarik oleh gaya magnet yang timbul tadi. Kontak Bantu NO (Normally Open) akan menutup dan kontak Bantu NC (Normally Close) akan membuka.

Kontak pada kontaktor terdiri dari kontak utama dan kontak Bantu. Kontak utama digunakan untuk rangkaian daya sedangkan ko-ntak Bantu digunakan untuk rangkaian kontrol. Didalam suatu kontaktor elektromagnetik terdapat kumparan utama yang terdapat pada inti besi. Kumparan hubung singkat berfungsi sebagai peredam getaran saat kedua inti besi saling melekat.

Apabila kumparan utama dialiri arus, maka akan timbul medan magnet pada inti besi yang akan menarik inti besi dari kumparan hubung singkat yang dikopel dengan kontak utama dan kontak Bantu dari kontaktor tersebut. Hal ini akan mengakibatkan kontak utama dan kontak bantunya akan bergerak dari posisi normal dimana kontak NO akan tertutup sedangkan NC akan terbuka.

Selama kumparan utama kontaktor tersebut masih dialiri arus, maka kontak-kontaknya akan tetap pada posisi operasinya. Apabila pada kumparan kontaktor diberi tegangan yang terlalu tinggi maka akan menyebabkan berkurangnya umur atau merusak kumparan kontaktor tersebut. Tetapi jika tegangan yang diberikan terlalu rendah maka akan menimbulkan tekanan antara kontak-kontak dari kontaktor menjadi berkurang. Hal ini menimbulkan bunga api pada permukaannya serta dapat merusak kontakkontaknya. Besarnya toleransi tegangan untuk kumparan kontaktor adalah berkisar $85 \%$ - $110 \%$ dari tegangan kerja kontaktor.

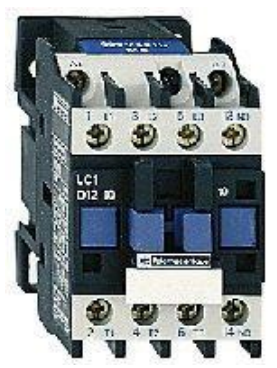

Gambar 2.18 Kontaktor (Magnetik Contactor)
3. Relay

Relay adalah saklar elektronik yang dapat membuka atau menutup rangkaian dengan menggunakan kontrol dari rangkaian elektronik lain. Sebuah relay tersusun atas kumparan, pegas, saklar (terhubung pada pegas) dan 2 kontak elektronik (normally close dan normally open)

a. Normally close (NC): saklar terhubung dengan kontak saat relay tidak aktif atau dapat dikatakan saklar dalam kondisi terbuka.

b. Normally open (NO): saklar terhubung dengan kontak saat relay aktif atau dapat dikatakan saklar dalam kondisi tertutup.

Berdasarkan pada prinsip dasar cara kerjanya, relay dapat bekerja karena adanya medan magnet yang digunakan untuk menggerakkan saklar.

Saat kumparan diberikan tegangan sebesar tegangan kerja relay maka akan timbul medan magnet pada kumparan karena adanya arus yang mengalir pada lilitan kawat. Kumparan yang bersifat sebagai elektromagnet ini kemudian akan menarik saklar dari kontak NC ke kontak NO.

Jika tegangan pada kumparan dimatikan maka medan magnet pada kumparan akan hilang sehingga pegas akan menarik saklar ke kontak NC.
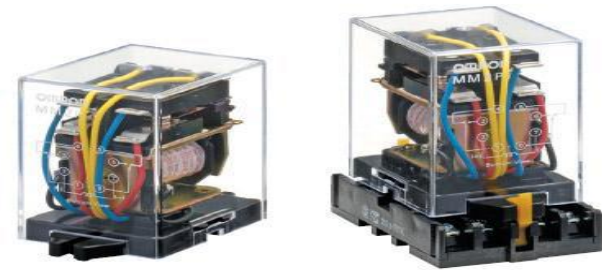

Gambar 2.19 Relay

\section{Inverter}

Inverter digunakan untuk mengubah sumber DC menjadi sumber AC, dimana tegangan yang di hasilkan dapat merupakan nilai yang konstan atau variabel. Suatu inverter sumber tegangan (Voltage Source 
Inverter = VSI) jika tegangan keluarannya konstan, inverter sumber arus (Current Source Inverter $=C S I$ ) jika arus keluarannya konstan, dan inverter hubungan DC yang variabel (variabel DC linked inverter) jika tegangan keluarannya dapat di kontrol atau di kendalikan lebih besar ataupun lebih kecil dari tegangan input.

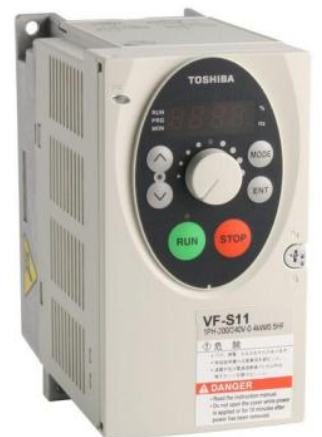

Gambar 2.20 Inverter Tipe Toshiba VF-S11

Fungsi Inverter adalah untuk merubah kecepatan motor AC dengan cara merubah Frekuensi Outputnya:

$\mathrm{f}=$ frekuensi $(\mathrm{Hz})$

$p=$ jumlah kutub

Jika sebelumnya banyak menggunakan sistem mekanik, kemudian beralih ke motor slip maka saat ini banyak menggunakan semikonduktor.

Tidak seperti softstarter yang mengolah level tegangan, inverter menggunakan frekuensi tegangan keluaran untuk mengatur speed motor pada kondisi ideal (tanpa slip).

Merubah kecepatan motor dengan Inverter akan membuat:

- Torsi lebih besar

- Presisi kecepatan dan torsi yang tinggi

- Kontrol beban menjadi dinamis untuk berbagai aplikasi motor

- Dapat berkombinasi dengan PLC/Programmable Logic Control untuk fungsi otomasi dan regulasi

- Menghemat energi

- Menambah kemampuan monitoring

- Hubungan manusia dengan mesin (interface) lebih baik
- Sebagai pengaman dari motor, mesin (beban) bahkan proses dll.

Semakin besar daya motor maka makin besar torsi yang dihasilkan dan makin kuat motor menggerakkan beban, Torsi dapat ditambah dengan menggunakan gear box (cara mekanis) dan Inverter (cara elektronik).

Proses di industri seringkali memerlukan tenaga penggerak dari motor listrik yang perlu diatur kecepatan putarnya untuk menghasilkan torsi dan tenaga/daya yang diinginkan. Torsi adalah gaya putar yang dihasilkan oleh motor listrik untuk memutar beban.

Kelebihan Torsi (over torque) terjadi jika torsi beban lebih besar dari Torsi nominal, pada $80 \%$ aplikasi terjadi pada saat kecepatan rendah atau saat start awal. Jika torsi inverter rendah akan mengakibatkan:

- Dinamika gerakan rendah (tidak memungkinkan gerakan beban yg kompleks).

- Motor sering overload (motor rusak atau thermal overload relay trip).

- Hentakan mekanis (Mesin/beban rusak, perlu perawatan intensif).

- Lonjakan arus (Motor rusak atau Breaker Trip).

- Presisi dalam proses hilang (Proses terancam).

- $\quad$ Proteksi tidak terjamin (Berbahaya.)

- Motor atau Inverter besar (Investasi bertambah)

Maka dapat disimpulkan, peranan inverter dalam proses suatu industri cukup penting. Karena dalam proses di industri seringkali memerlukan tenaga penggerak dari motor listrik yang perlu diatur kecepatan putarnya untuk menghasilkan torsi dan tenaga/daya yang diinginkan.

\section{MCB (Miniature Circuit Breaker)}

Singkatan MCB adalah Mini Circuit Breaker yang memiliki fungsi sebagai alat pengaman arus lebih. MCB ini memproteksi 
arus lebih yang disebabkan terjadinya beban lebih dan arus lebih karena adanya hubungan pendek. Dengan demikian prinsip dasar bekerjanya yaitu untuk pemutusan hubungan yang disebabkan beban lebih dengan relai arus lebih seketika digunakan elektromagnet.

Bila bimetal ataupun elektromagnet bekerja, maka ini akan memutus hubungan kontak yang terletak pada pemadam busur dan membuka saklar. MCB untuk rumah seperti pada pengaman lebur diutamakan untuk proteksi hubungan pendek, sehingga pemakaiannya lebih diutamakan untuk mengamankan instalasi atau konduktornya. Sedang MCB pada APP diutamakan sebagai pembawa arus dengan karakteristik $\mathrm{CL}$ (current limiter) disamping itu juga sebagai gawai pengaman arus hubung pendek yang bekerja seketika.

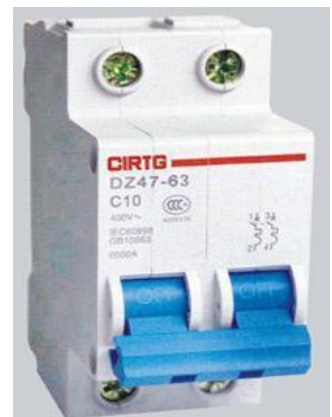

Gambar 2.21 MCB (Miniature Circuit Breaker)

\section{Thermal Overload Relay (TOR)}

Adalah pengaman beban lebih atau overload yang digunakan pada instalasi beban motor listrik adalah TOR. Jika arus yang melaui penghantar yang menuju motor listrik melebihi kapasitas atau seting TOR, maka TOR drop atau terputus sehingga rangkaian yang menuju motor listrk terputus. TOR dihubungkan dengan kontaktor pada kontak utama (untuk seri magnet kontaktor tertentu).Rotasi kontak utamanya adalah 2,4,6 sebelum beban atau motor listrik.

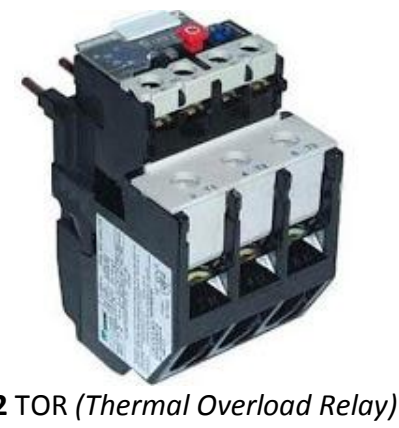

Beberapa penyebab terjadinya beban lebih:

- Beban mekanik pada motor listrik terlalu besar

- Arus start terlalu besar dan terlalu lama putaran nominal tercapai atau motor listrik berhenti secara mendadak

- Terjadi hubungan singkat pada motor listrik antara fasa dengan fasa,atau antara fasa dengan body

- Motor listrik bekerja hanya dengan dua fasa atau terbukanya salah satu fasa dari motor listrik tiga fasa.

Prinsip kerja termal beban berdasarkan panas atau temperature yang ditimbulkan oleh arus yang mengalir melalui elemenelemen pemanas bimetal. Jika panas berlebihan maka salah satu logam bimetal melengkung dan menggerakkan kontak mekanis pemutus rangkaian listrik (untuk bimetal seri tertentu).

\section{ANALISA dan PEMBAHASAN}

\subsection{Penanganan Sensor}

Sensor yang digunakan conveyor dalam penelitian ini adalah sensor photodioda. Banyaknya sensor yang digunakan suatu conveyor tergantung panjangnya conveyor tersebut. Jadi semakin panjang suatu conveyor semakin banyak sensor yang di guna-kan. Photodioda digunakan sebagai detektor cahaya dan LED (Light Emiting Dioda) yaitu dioda pemancar cahaya, yang digunakan sebagai sumber cahaya yang diletakkan pada suatu tempat dimana objek dapat dideteksi ketika memotong garis cahaya. Jadi apabila barang 
di atas conveyor tersebut menumpuk dan menghalangi sensor photodioda yang saling berhadapan tersebut maka conveyor tersebut akan berhenti. Berikut contoh gambar sensor photodioda yang digunakan PT. XYZ.

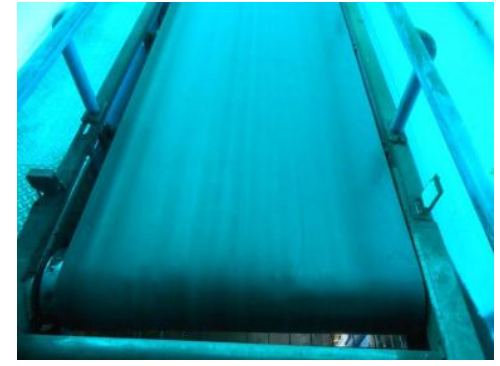

Gambar 3.1 Sensor Photodioda lity:

Indikasi ganda memastikan tinggi visibi-

- Kesesuaian dengan warna terdaftar dapat dipantau di delapan tingkat. (Deteksi Indikator tingkat)

- Memungkinkan penyesuaian halus antara halus atau diskriminasi kasar sementara pemantauan hasil yang diukur. (Indikator tingkat Threshold)

Stabil dan Powerfull Deteksi untuk Inline:

- Deteksi Stabil terjamin dengan ambang $\pm 10 \mathrm{~mm}$ untuk built-in jenis amplifier dan $\pm 4 \mathrm{~mm}$ untuk jenis serat optik.

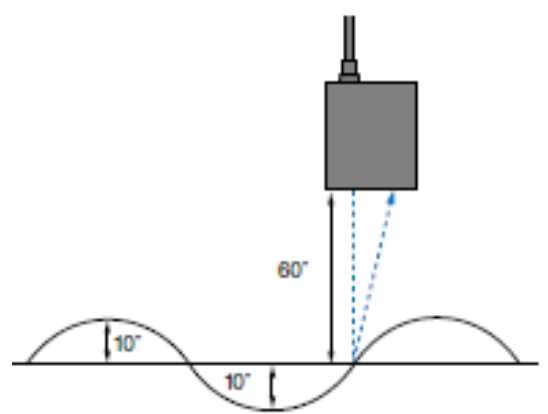

Gambar 3.2 Jarak sensor dengan benda

\section{Prinsip Deteksi:}

E3MC mendeteksi warna dengan memanfaatkan fakta bahwa refleksi rasio warna primer (yaitu merah, hijau atau biru) tercermin oleh objek bervariasi dengan chromatically objek. Dengan menggunakan hightech sebuah, multi-layer terpolarisasi penyaring yang disebut FAO (optik sudut gratis), E3MC memancarkan merah, hijau dan biru muda pada sumbu optik tunggal. E3MC menerima cahaya yang dipantulkan oleh penginderaan objek melalui penerima dan proses rasio merah-hijau-biru cahaya untuk membedakan warna obyek penginderaan.

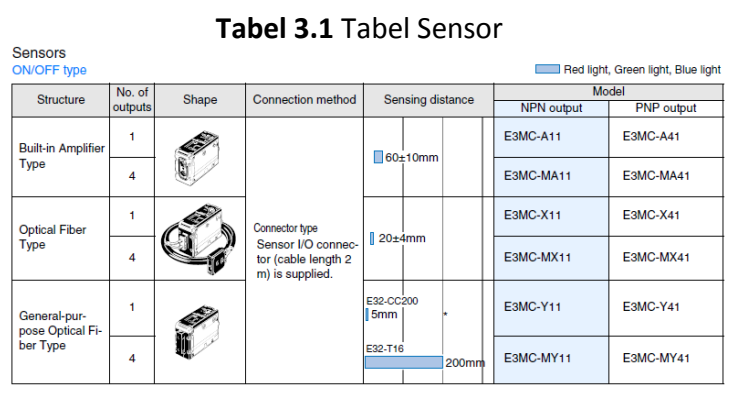

Tabel 3.2 Analog Output Type

\begin{tabular}{|l|c|c|c|c|}
\hline \multicolumn{1}{|c|}{ Analog output type } \\
\hline $\begin{array}{l}\text { Built-in Amplifier } \\
\text { Type }\end{array}$ & Shape & \multicolumn{2}{|c|}{ Sensing distance } & Model \\
\hline Optical Fiber Type & E3MC-A81 & & & \\
\hline $\begin{array}{l}\text { General-purpose } \\
\text { Optical Fiber Type }\end{array}$ & E3MC-X81 & & & \\
\hline
\end{tabular}

Tabel 3.3 Accessories Accessories (Order Separately) Sensor I/O Connectors

\begin{tabular}{|c|c|c|c|c|}
\hline Shape & \multicolumn{2}{|c|}{ Model } & Quantity & Remarks \\
\hline \multirow{2}{*}{$\mathbb{Q}(\mathbb{\square} \square=$} & \multicolumn{2}{|c|}{ E39-C1 2M (2 m) } & $1 \mathrm{pc}$. & Supplied with the product. \\
\hline & \multicolumn{2}{|c|}{ E39-C1 5M (5 m) } & $1 \mathrm{pc}$. & $\begin{array}{l}\text { Please place an order } \\
\text { when extending the cable. }\end{array}$ \\
\hline \multicolumn{5}{|c|}{ Mounting Brackets } \\
\hline Shape & Model & Quanti- & & Remarks \\
\hline 6 & E39-L114 & 2 & \multicolumn{2}{|c|}{$\begin{array}{l}\text { For E3MC installation. } \\
\text { (Can be inclined to } 15^{\circ} \text { ) }\end{array}$} \\
\hline & E39-L115 & 1 & \multicolumn{2}{|c|}{ For DIN track installation. } \\
\hline
\end{tabular}

\subsection{Pengaturan Inverter}

Inverter merupakan sebuah alat pengatur kecepatan motor dengan mengubah nilai frekuensi dan tegangan yang masuk ke motor. Pengaturan nilai frekuensi dan tegangan ini dimaksudkan untuk mendapatkan kecepatan putaran dan torsi motor yang di inginkan atau sesuai dengan kebutuhan. 
Secara sederhana prinsip dasar inverter untuk dapat mengubah frekuensi menjadi lebih kecil atau lebih besar yaitu dengan mengubah tegangan $A C$ menjadi tegangan $D C$ kemudian dijadikan tegangan AC lagi dengan frekuensi yang berbeda atau dapat diatur.

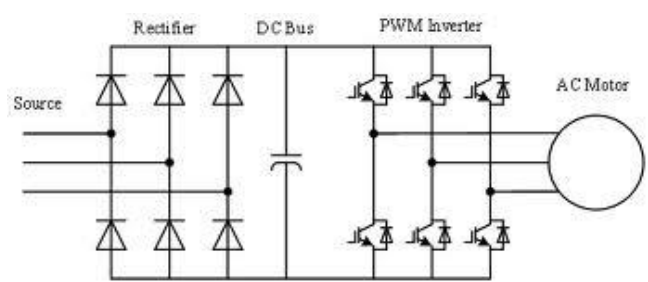

Gambar 3.3 Diagram Inverter

Untuk mengubah tegangan $A C$ menjadi DC dibutuhkan penyearah (converter AC-DC) dan biasanya menggunakan penyearah tidak terkendali (rectifier dioda) namun juga ada yang menggunakan penyearah terkendali (thyristor rectifier). Setelah tegangan sudah diubah menjadi DC maka diperlukan perbaikan kualitas tegangan DC dengan menggunakan tandon kapasitor sebagai perata tegangan. Kemudian tegangan DC diubah menjadi tegangan $A C$ kembali oleh inverter dengan teknik PWM (Pulse Width Modulation). Dengan teknik PWM ini bisa didapatkan amplitudo dan frekuensi keluaran yang diinginkan. Selain itu teknik PWM juga menghasilkan harmonisa yang jauh lebih kecil dari pada teknik yang lain serta menghasilkan gelombang sinusoidal, dimana kita tahu kalau harmonisa ini akan menimbulkan rugi-rugi pada motor yaitu cepat panas. Maka dari itu teknik PWM inilah yang biasanya dipakai dalam mengubah tegangan $D C$ menjadi $A C$ (inverter). Memang ada banyak cara untuk mengatur/mengurangi kecepatan motor seperti dengan gear box/ reducer. Namun mengatur kecepatan motor dengan inverter akan memperoleh banyak keuntungan yang lebih bila dibandingkan dengan cara-cara yang lain. Seperti: jangkauan yang luas untuk pengaturan kecepatan dan torsi motor, mempunyai akselerasi dan deselerasi yang dapat diatur, mempermudah proses monitoring/ pengecekan, sistem proteksi motor yang baik, mengurangi arus starting motor dan menghemat pemakaian energi listrik, memperhalus start awal motor dll.

Pemilihan inverter yang benar tentunya dengan memperhatikan spesifikasi dari motor serta keperluan dalam pemakaian inverter itu sendiri. seperti dengan memperhatikan daya motor, tegangan motor, frekuensi motor. contohnya anda memiliki motor 3 phase $3 \mathrm{KW}$, maka anda perlu menggunakan inverter dengan spesifikasi daya diatas $3 \mathrm{kw}$ seperti 3,2 kw atau 3,3 kw dan tentunya tegangan keluaran dari inverter harus sama dengan tegangan motor. sebenarnya anda juga bisa menggunakan inverter dengan daya $3 \mathrm{kw}$ untuk motor $3 \mathrm{kw}$ tapi dengan 20 syarat anda menggunakan motor tersebut dengan beban yang kecil atau dengan kata lain motor tidak digunakan dengan daya maksimal. Jadi penting untuk mengetahui arus pada motor saat dijalankan dengan beban, untuk setingan ampere pada inverter sebagai proteksi motor, serta untuk menghitung daya beban yang berguna dalam pemilihan inverter.

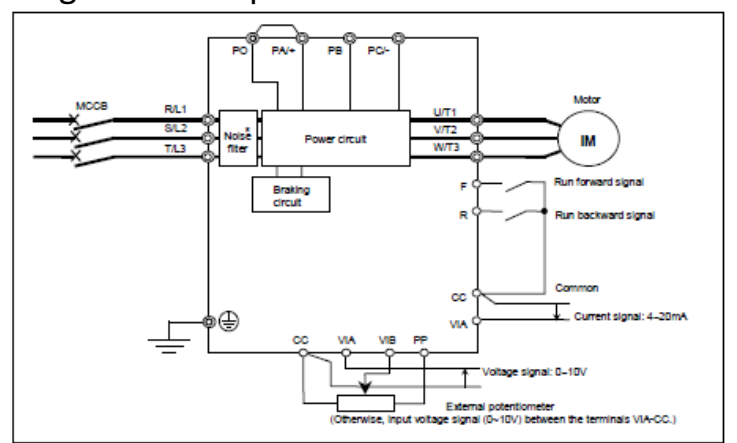

Gambar 3.4 Wiring Inverter

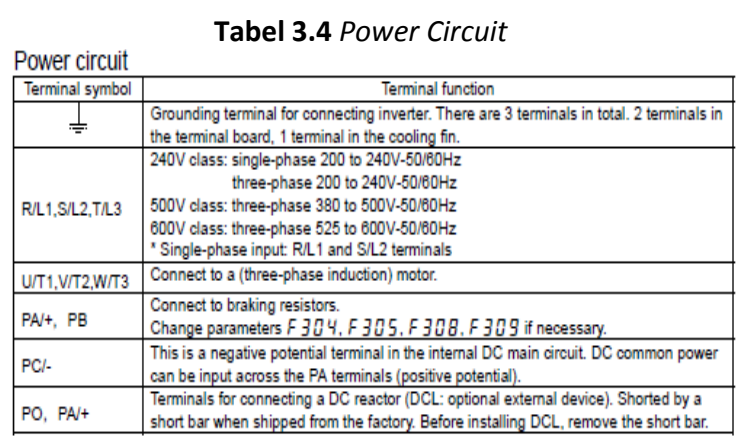


Tabel 3.5 Parameter Input Output

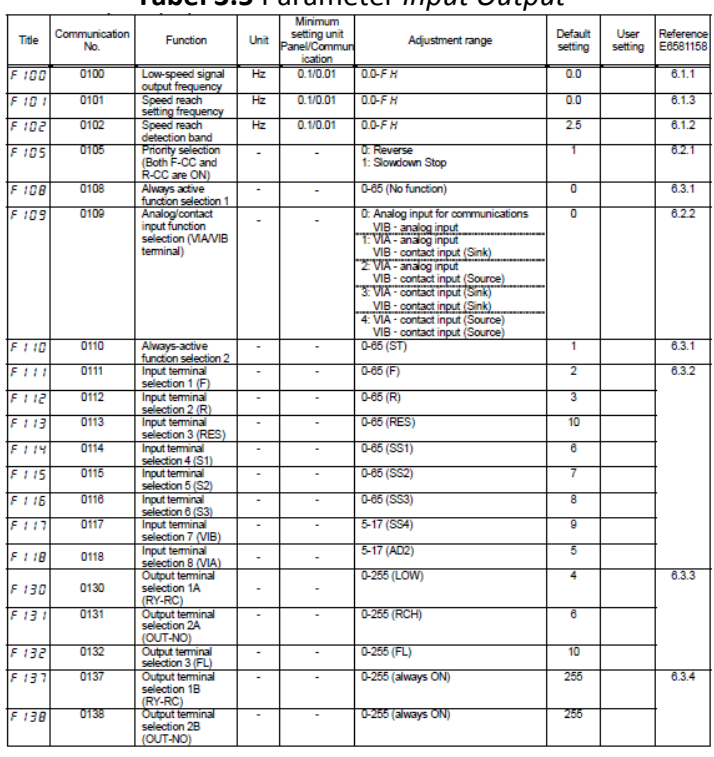

\subsection{Sistem Kontrol}

Sistem yang terdiri dari beberapa elemen sistem yang dapat mengendalikan/ mengatur suatu besaran tertentu. yang dapat diidentifikasi atau ditengarai terdiri dari minimal 2 (dua) bagian utama, yaitu:

- $\quad$ Plant/proses, obyek yang dikendalikan

- Kontroller/Pengendali, yang mengendalikan

Definisi-Definisi:

- Input (Set Point, Reference)

Respon sistem yang diinginkan

- Output

Respon sistem sebenarnya

- Plant

Obyek yang dikontrol atau objek fisik yang dikendalikan (tungku pemanas, reaktor nuklir, pesawat ruang angkasa)

- Proses

Operasi yang dikontrol

- Gangguan

Sinyal yang mempunyai pengaruh merugikan terhadap keluaran sistem

- Umpan Balik

Kemampuan suatu sistem untuk membandingkan outputnya dengan inputnya (output yang ingin dicapai) sehingga selisih antara output dengan input (sinyal galat), akan menyebabkan output berubah sehingga menyamai input.

\subsection{Sistem Kontrol Otomatis}

Suatu sistem kontrol otomatis dalam suatu proses kerja berfungsi mengendalikan proses tanpa adanya campur tangan manusia (otomatis). Ada dua sistem kontrol pada sistem kendali/kontrol otomatis yaitu:

A. Open Loop (Loop Terbuka)

Suatu sistem kontrol yang keluarannya tidak berpengaruh terhadap aksi pengontrolan. Dengan demikian pada sistem kontrol ini, nilai keluaran tidak di umpan-balikkan ke parameter pengendalian.

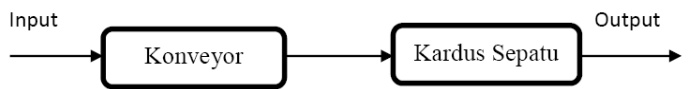

Gambar 3.5 Diagram Blok Sistem Pengendalian Loop Terbuka

Karakteristik Sistem kendali loop terbuka:

- output tidak diukur maupun di umpanbalikkan

- ketepatan hasil bergantung pada kalibrasi.

- hubungan antara output dan input diketahui

- tidak ada 'internal disturbance' maupun 'eksternal disturbance'

- terkait dengan waktu

Kelebihan:

- konstruksinya sederhana dan perawatannya mudah

- lebih murah

- tidak ada persoalan kestabilan

- cocok untuk keluaran yang sukar diukur /tidak ekonomis (contoh: untuk mengukur kualitas keluaran pemanggang roti)

Kelemahan:

- Tidak dapat memberikan kompensasi/ koreksi jika ada gangguan

- gangguan dan perubahan kalibrasi

- untuk menjaga kualitas yang diinginkan perlu kalibrasi ulang dari waktu ke waktu. 
Contoh:

- Van Belt

- Motor \& Gear Box

\section{B. Close Loop (Loop Tertutup)}

Suatu sistem kontrol yang sinyal keluarannya memiliki pengaruh langsung terhadap aksi pengendalian yang dilakukan. Sinyal error yang merupakan selisih dari sinyal masukan dan sinyal umpan balik (feedback), lalu diumpankan pada komponen pengendalian (controller) untuk memperkecil kesalahan sehingga nilai keluaran sistem semakin mendekati harga yang diinginkan. Keuntungan sistem loop tertutup adalah adanya pemanfaatan nilai umpan balik yang dapat membuat respon sistem kurang peka terhadap gangguan eksternal dan perubahan internal pada parameter sistem Kerugiannya adalah tidak dapat mengambil aksi perbaikan terhadap suatu gangguan sebelum gangguan tersebut mempengaruhi nilai prosesnya.

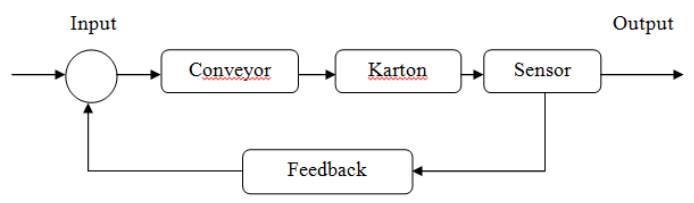

Gambar 3.6 Diagram Blok Sistem Kontrol Tertutup

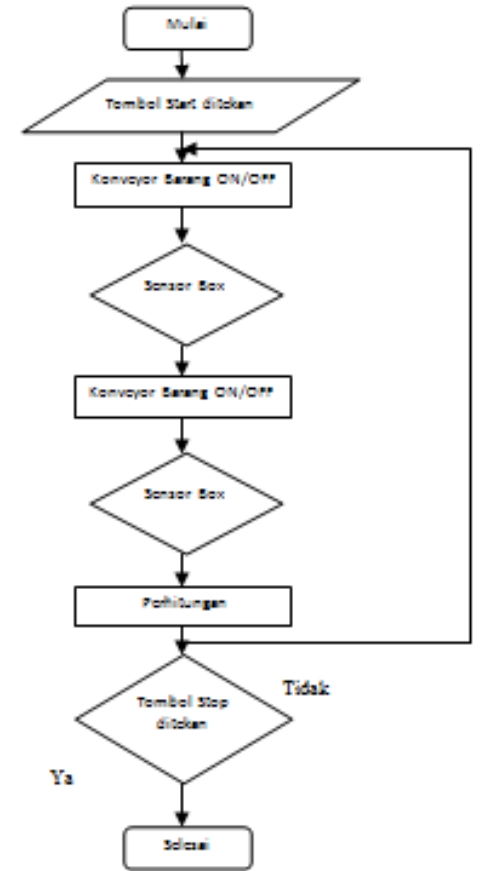

Gambar 3.7 Diagram Alir Konveyor Penghitung Barang

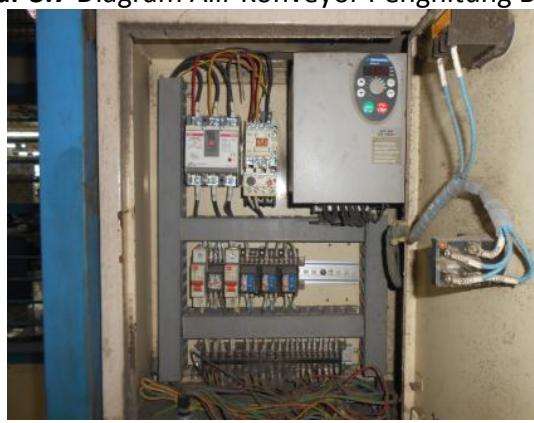

Gambar 3.8 Komponen di Panel Box

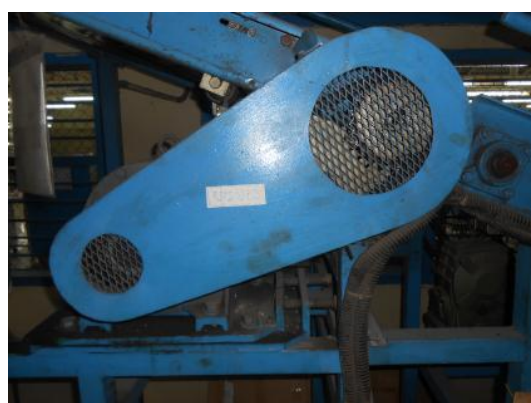

Gambar 3.9 Sambungan Gear Box dengan Conveyor Belt 


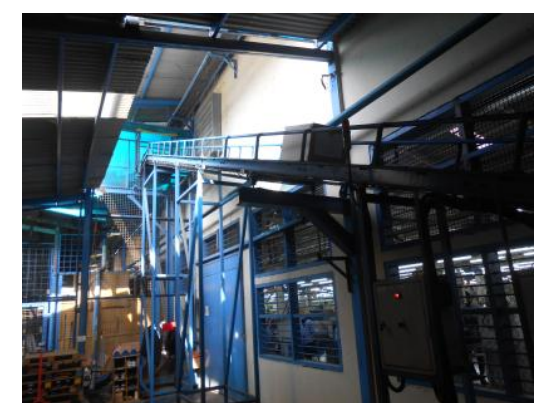

Gambar 3.10 Conveyor Belt

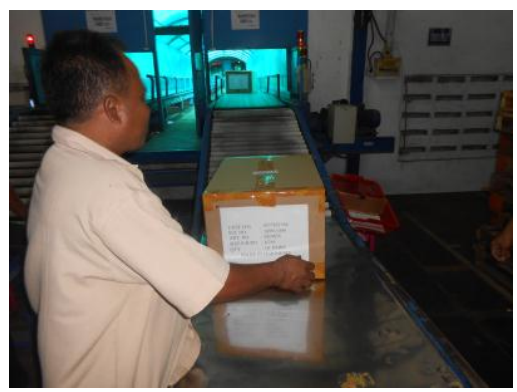

Gambar 3.11 Penerimaan Dus Berisi Produk Dari Produksi Ke Gudang

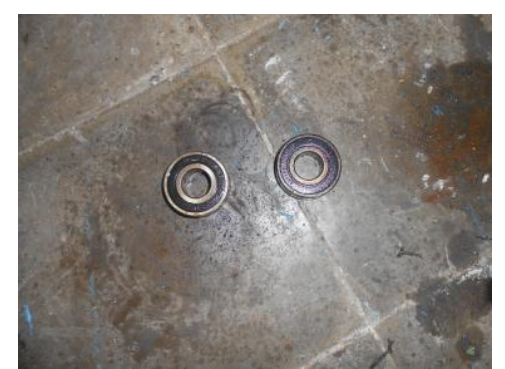

Gambar 3.12 Bearing yang Sudah Rusak (Haus)

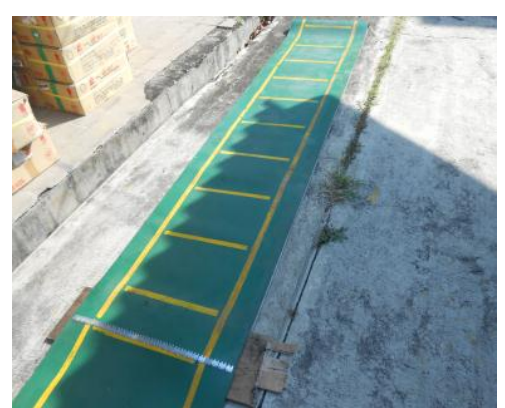

Gambar 3.13 Penyambungan Van Belt yang putus menggunakan Steel Belt Lacing

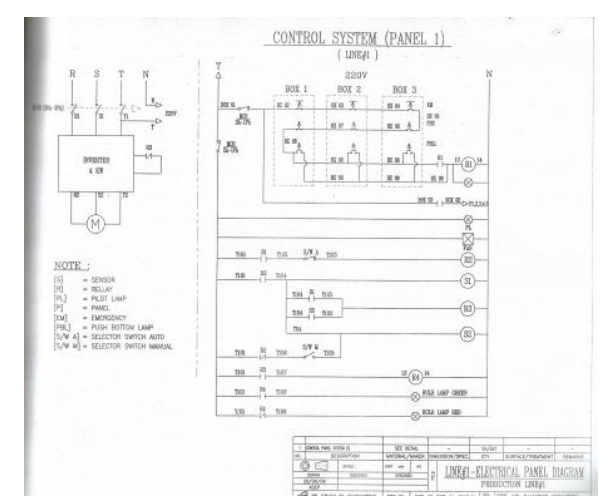

Gambar 3.14 Diagram Kelistrikan Panel Box 1

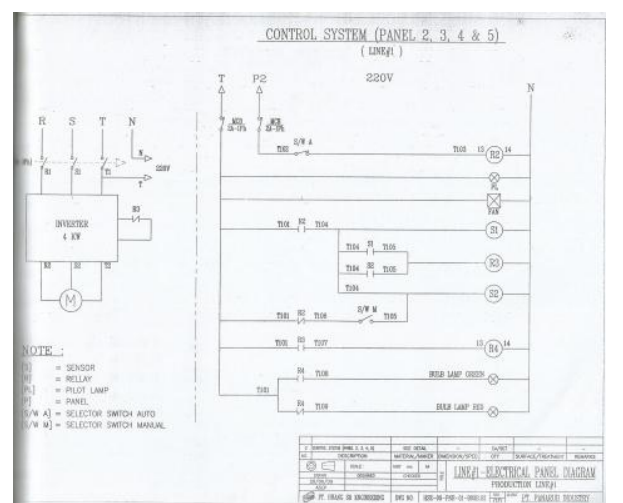

Gambar 3.15 Diagram Kelistrikan Panel Box 2, 3, 4 \& 5

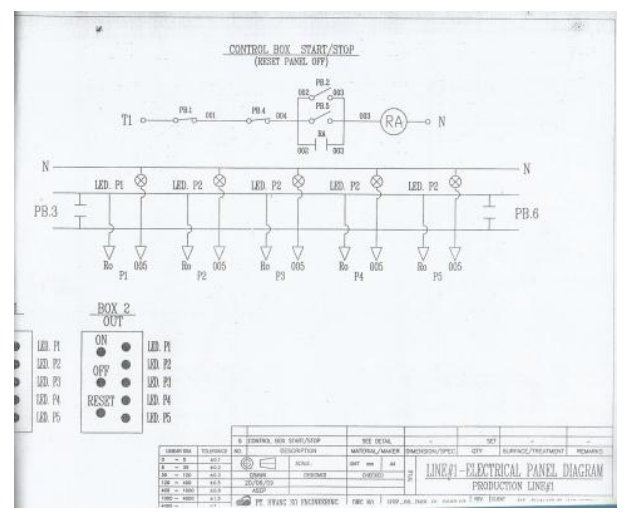

Gambar 3.15 Diagram Kontrol Box Start/Stop

\section{KESIMPULAN}

Dari hasil kerja praktek yang penulis lakukan di PT. XYZ, ada beberapa kesimpulan sebagai berikut ini:

1. Dalam pembuatan conveyor belt di perhatikan tempat meletakan sensor, karena sangat berpengaruh apabila bergeser sedikit pun. 
2. Penyesuaian kekuatan torsi kekuatan motor harus di sesuaikan dengan gearbox yang di pasang.

3. Dalam penggunaan inverter di harapkan menyesuaikan kondisi motor dan gearbox-nya.

4. Dari penelitian ini diperoleh kesimpulan dalam 1 hari conveyor belt tersebut dapat membawa kurang lebih 600 karton pada speed inverter 28-32 Rpm yang sepatu dari produksi ke gudang, dibandingkan dengan membawa manual yang membutuhkan waktu yang lama dan tenaga yang kuat.

\section{DAFTAR PUSTAKA}

Muchsin, Ismail. Pusat Pengembangan Bahan Ajar-UMB Elektronika \& Motor Listrik. ELETRONIKA \& MOTOR LIST ELETRONIKA \& MOTOR.
Mohamad Yamin, Widyo Purwoko. Perencanaan Gear Box Dan Analisis Statik Rangka Conveyor Menggunakan Software CATIA V5.

Muslimin, Zaenab. Pengontrolan Motor Induksi Tiga Fasa dengan Inverter Berbasis Mikrokontroler AT89S51, Universitas Hasanuddin, 2009.

Triyono, Modul Dasar Sistem Kontrol, Teknik Elektro FT-UMT, 2014.

Manual book, Rubber Belt Conveyor Ass'y, PT. Hwang So Engineering, 2009-2010.

Data Sheet Inverter.

Data Sheet Sensor. 


\title{
ANALISA PENGENDALIAN KUALITAS RESIN ABC MENGGUNAKAN SIX SIGMA DI PT. PARDIC JAYA CHEMICALS
}

\author{
Tri Widodo, Hari Priyadi \\ Program Studi Teknik Industri, Fakultas Teknik, \\ Universitas Muhammadiyah Tangerang \\ Jl. Perintis Kemerdekaan I/33, Cikokol, Kota Tangerang
}

\begin{abstract}
ABSTRAK
Perkembangan teknologi di dunia bisnis dan perdagangan membuat persaingan menjadi ketat dan tajam. Dalam usahanya untuk memenuhi kepuasan konsumen yang makin tinggi, maka perusahaan harus dapat menentukan faktor kualitas yang diminta oleh konsumen, selain faktor harga, design, dan faktor lainnya.Salah satu metode yang dapat dilakukan perusahaan untuk selalu meningkatkan kualitas produksi adalah dengan menggunakan metode Six Sigma. Six Sigma merupakan pengendalian kualitas yang targetnya yaitu 3,4 DPMO atau 3,4 cacat per sejuta kesempatan. Dengan adanya target six sigma yang 3,4 DPMO maka dapat dikatakan realitas untuk dapat dicapai dari pengendalian kualitas yang berdasar pada zero defect. Pengendalian kualitas yang dipakai dalam penelitian ini menggunakan pendekatan six sigmadengan metodologi DMAIC (Define, Measure, Analyze, Improve, Control), yang dilakukan di tiap proses produksi tetapi sebelum melaksanakan pengendalian kualitas dengan metode sixsigmaperlu adanya rencana agar pelaksanaan six sigma dapat sukses diterapkan.Pengendalian kualitas dibutuhkan PT. Pardic Jaya Chemicals untuk tetap menjaga proses produksi menjadi aliran proses yang kuat dan handal sehingga pencapaian level sigma sebesar 3,46 dan DPMO sebesar 25514,4 dapat lebih ditingkatkan serta tidak ada lagi hasil produksi yang cacat atau dengan kata lain tidak ada lagi kerugian bagi perusahaan karena produk cacat.
\end{abstract}

Kata kunci:Teknologi, Six Sigma, DPMO,zero defect, DMAIC(Define, Measure, Analyze, Improve, Control).

\section{PENDAHULUAN}

PT. Pardic Jaya Chemicals adalah salah satu perusahaan resin sintetis yang selalu berusaha menghasilkan resin sintetis yang sesuai dengan standar demi memuaskan pelanggan. Pada kenyataannya, masih terdapat produk yang defect/cacat. Hal ini tentunya tidak sesuai dengan target peru-sahaan yang menginginkan hasil produksi yang sempurna demi menghadapi persaingan dunia bisnis yang semakin ketat.

Salah satu metode yang dapat digunakan untuk mengendalikan kualitas dan meng- atasi cacat produk yang banyak adalah metode six sigma. Melalui penekanan pada kemampuan proses (Process Capability), industri dapat mengharapkan 3.4 kegagalan per sejuta kesempatan (DPMO - Defects Per Million Opportunities). Six sigma sendiri merujuk kepada target kinerja operasi yang diukur secara statistik dengan hanya 3,4 cacat (defect) untuk setiap juta aktivitas atau peluang. Dengan kata lain, six sigma adalah sebuah konteks yang didalamnya kita akan dapat mengintegrasikan banyak "praktik terbaik" serta konsep manajemen yang 
berharga tapi sering kali tidak berkaitan, mencakup pemikiran sistem, perbaikan terus menerus, knowledge Management, mass customization, dan manajemen berbasis aktivitas (activity-based management) (Pande dkk, 2002:82). Tujuan penelitian ini adalah untuk mengetahui faktor-faktor penyebab defect yang terjadi pada produk resin $A B C$ dan mengetahui prioritas usulan perbaikan yang dapat digunakan untuk mengurangi jumlah defect pada resin $\mathrm{ABC}$.

\section{METODE PENELITIAN}

Metode yang digunakan dalam penelitian ini adalah six sigma. Aplikasi six sigma berfokus pada cacat dan variasi, dimulai dengan mengidentifikasi unsur-unsur kritis terhadap kualitas (Critical to Quality - CTQ) dari suatu proses. Six sigma menganalisa kemampuan proses dan bertujuan menstabilkannya dengan cara mengurangi atau menghilangkan variasi-variasi. Langkah mengurangi cacat dan variasi dilakukan secara sistematis dengan mendefinisikan, mengukur, menganalisa, memperbaiki, dan mengendalikannya. Langkah penelitian yang dilakukan adalah:

1. Survey pendahuluan yang dilakukan pada PT Pardic Jaya Chemicals untuk mengetahui kondisi umum perusahaan;

2. Identifikasi masalah dengan membahas masalah yang terkait atribut produk yang tidak sesuai dengan spesifikasi;

3. Studi Literatur yang dilakukan dengan cara mempelajari buku dan jurnal ilmiah untuk mendapatkan referensi terkait dengan topik yang dibahas pada penelitian ini;

4. Pengumpulan data yang dilakukan untuk mendapatkan data mengenai jumlah produk defect serta tipe defect;

5. Analisa yang dilakukan melalui tahap define, measure, analyze, dan improve menggunakan data yang telah diperoleh dari tahap pengumpulan data;

6. Pembahasan yang dilakukan untuk me- nguraikan lebih rinci terkait hasil yang diperoleh dari tahap analisa;

7. Kesimpulan yang merupakan jawaban atas permasalahan yang ada. Analisis pada penelitian ini dilakukan dengan menggunakan metode six sigma melalui tahap sebagai berikut:

\subsection{Define}

Pada tahap ini PT. Pardic Jaya Chemicals mendefinisikan masalah-masalah kualitas produk resin $A B C$ dengan cara menghitung persentase produk cacat terhadap jumlah produksi pada bulan Januari sampai September 2014. Pada tahap ini ditentukan proporsi defect yang menjadi penyebab paling signifikan terhadap adanya kerusakan produk. Langkah-langkah yang dilakukan pada tahap define ini adalah sebagai berikut:

a. Mendefinisikan kriteria pemilihan proyek yang ada di perusahaan PT. Pardic Jaya Chemicals.

Pada tahap ini PT. Pardic Jaya Chemicals mendefinisikan masalah-masalah kualitas produk resin $A B C$, proses produksi dengan cara menghitung persentase produk cacat terhadap jumlah produksi pada bulan Januari sampai September 2014.

Prosentase produk cacat $=\frac{\text { jumlan produk cacat }}{\text { jumlah produk }} \times 10036$

b. Mendefinisikan peran orang-orang yang terlibat dalam memproduksi resin $A B C$ di PT. Pardic Jaya Chemicals.

Jabatan yang berkaitan dengan masalah produksi adalah pada jabatan bagian produksi. Permasalahan yang timbul seperti kurangnya pengawasan dalam memproduksi resin $A B C$, hal ini disebabkan karena mereka masih memiliki sedikit pengetahuan atau wawasan yang lebih luas mengenai pengendalian kualitas, maka salah satu cara untuk menanganinya yaitu semua individu yang terlibat pada bagian produksi diberikan sebuah 
training dan penyuluhan mengenai pengendalian kualitas.

c. Mendefinisikan proses kunci beserta pelanggan dari produk resin $A B C$ dengan metode Six Sigma

Dengan membandingkan standarisasi yang telah ditetapkan perusahaan yaitu tidak lebih $1 \%$ dari jumlah produk pada proses produksi dengan hasil perhitungan persentase produk cacat resin $A B C$ terhadap jumlah produk resin pada bulan Januari sampai September 2014.

\subsection{Measure}

Langkah-langkah yang dilakukan pada tahapmeasure ini adalah sebagai berikut:

a. Menetapkan karateristik kualitas (CTQ) kunci

Langkah ini menetapkan karateristik kunci apa saja yang dapat menyebabkan suatu produk tidak memenuhi harapan pelanggan.

b. Melakukan pengukuran baseline kinerja

Pada langkah ini dilakukan pengukuran tingkat kinerja perusahaan sebelum proyek six sigma berlangsung dapat dilihat. Langkahlangkah untuk melakukan pengukuran baseline kinerja adalah sebagai berikut:

a. Menetapkan periode waktu yang akan diuji

b. Menuliskan jumlah produk yang akan diperiksa selama periode no.1 pada kolom tabel (B)

C. Menuliskan jumlah produk cacat pada kolom tabel (C)

d. Menuliskan jumlah CTQ potensial penyebab kecacatan produk pada tabel (D)

e. Menghitung dan menuliskan DPMO pada kolom tabel $\mathrm{D}$ dengan menggunakan

$$
\text { rumus:DPMO }=\frac{\mathrm{C}}{\mathrm{B} \times \mathrm{D}} \times 1.000 .000
$$

f. Mengkonversi DPMO menjadi nilai sigma, dengan menggunakan tabel Konversi Hasil Bebas Cacat ke Nilai Sigma dan DPMO

\subsection{Analyze}

Langkah-langkah yang dilakukan pada tahap analyze adalah sebagai berikut:

a. Melakukan analisis kapabilitas proses Pada langkah ini dilakukan perhitungan CTQ potensial untuk mengetahui CTQ potensial tertinggi yang menyebabkan terjadinya produk cacat. Langkah yang ditempuh untuk menghitung CTQ potensial tertinggi yaitu:

1. Menghitung frekuensi dari setiap СTQ yang kemudian hasilnya dituliskan ke dalam tabel

2. Menggambarkan hasil perhitungan ke dalam Diagram Pareto

b. Mengidentifikasi sumber-sumber penyebab produk cacat

Pada langkah ini diidentifikasi sumbersumber penyebab terjadinya produk cacat. Oleh karena itu digunakan diagram sebab akibat atau diagram Ishikawa (Fish Bone) yang sering disebut diagram tulang ikan. Dalam penelitian ini penyebab kerusakan produk hanya ditinjau dari:

1. Man/manusia yang terlibat langsung dalam proses produksi

2. Material/bahan baku yang digunakan dalam proses produksi

3. Machine/mesin dan peralatan yang digunakan dalam proses produksi

4. Method/metode yang digunakan dalam proses produksi

5. Media/lingkungan yang terlibat langsung atau yang tidak langsung dalam proses produksi

\subsection{Improve}

Menetapkan rencana tindakan (actionplan) untuk melaksanakan peningkatan kualitas six sigma. Rencana mendeskripsikan tentang alokasi sumber daya serta prioritas dan alternatif yang dilakukan dalam implementasi dari rencana itu. Perancangan pada tahap improve dilakukan dengan cara melalui tahap-tahap merancang metode $5 \mathrm{~W}-1 \mathrm{H}$ 
(What-tujuan, Why-alasan kegunaan, Wherelokasi, When-kapan, Who-orang, dan Howmetode).

a. Improve pada faktorMan: ditentukan apakah tujuan improve pada faktor Man, alasan kegunaannya, lokasi, sekuens, dan bagaimana caranya.

b. Improve pada faktor Machine: ditentukan apakah tujuan improve pada faktor $\mathrm{Ma}$ chine, alasan kegunaannya, lokasi, sekuens, dan bagaimana caranya.

c. Improve pada faktor Material: ditentukan apakah tujuan improve pada faktor $\mathrm{Ma}$ terial, alasan kegunaannya, lokasi, sekuens, dan bagaimana caranya.

d. Improve pada faktor Method: ditentukan apakah tujuan improve pada faktor $\mathrm{Me}$ thod, alasan kegunaannya, lokasi, sekuens, dan bagaimana caranya.

e. Improve pada faktor Media: ditentukan apakah tujuan improve pada faktor Media, alasan kegunaannya, lokasi, sekuens, dan bagaimana caranya.

\subsection{Control}

Perancangan pada tahapcontrol dilakukan dengan merancang hasil-hasil peningkatan kualitas yang akan kemudian akan mengintegrasikan hasil six sigma ke cara-cara praktek bisnissehingga tercapai pengendalian kualitas perusahaan.

\section{ANALISA \& PEMBAHASAN}

\subsection{Tahap Define}

Fase ini terkait dengan identifikasi proses atau produk yang membutuhkan perbaikan. Tujuan yang akan dicapai adalah mengurangi jumlah defect pada hasil produksi. Defect yang menjadi fokus perbaikan adalah produk yang mempunyai prosentase defect paling besar atau paling dominan. Yang pertama dilakukan adalah mencari produk-produk yang menyebabkan kerugian terbesar karena terjadi defect.

\begin{tabular}{|c|c|c|}
\hline No & ProductType & Quantities (kg) \\
\hline 1 & Acrydic & 167000 \\
\hline 2 & Polylite & 310000 \\
\hline 3 & Beckosol & 98560 \\
\hline 4 & Burnock & 325000 \\
\hline 5 & Dicdry & 285000 \\
\hline 6 & Precom & 20000 \\
\hline 7 & Styresol & 15000 \\
\hline & Total & $\mathbf{1 2 2 0 5 6 0}$ \\
\hline
\end{tabular}

Dari tabel diatas terlihat produk Burnock adalah produk yang kuantiti produksinya paling besar.

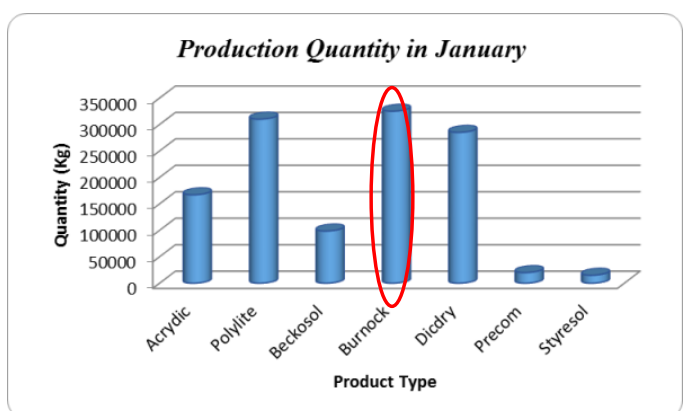

Dari tipe produk burnock ada beberapa macam resin yang diproduksi dan beberapa diantaranya terjadi defect. Hal ini terlihat pada grafikdibawah ini:

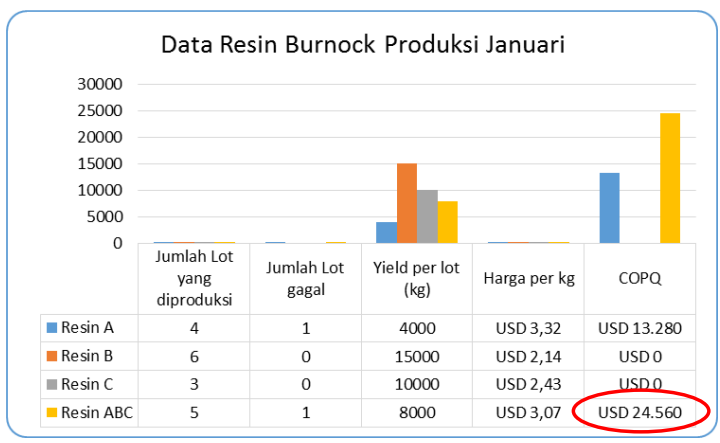

Dari tabel diatas dapat diketahui bahwa produk tipe burnock yang menyebabkan kerugian terbesar adalah kegagalan produksi pada jenis resin $A B C$ yang mempunyai tingkat COPQ terbesar yaitu USD 24.560 selama produksi bulan Januari saja. Bisa dibayangkan bila kegagalan tersebut tidak segera ditindaklanjuti maka kerugian perusahaan akan semakin bertambah besar yang dikarenakan produk cacat. Berdasarkan data diatas maka 
diambil data dari total jumlah produksi yang diperiksa, banyaknya hasil produksi yang tidak memenuhi standar, dan persentase produk yang tidak memenuhi standar produksi resin $A B C$ selama periode Januari sampai September 2014 dan datanya adalah sebagai berikut:

\begin{tabular}{|c|c|c|c|}
\hline Bulan & $\begin{array}{c}\text { Jumlah item resin } \\
\text { ABC yang diperiksa }\end{array}$ & $\begin{array}{c}\text { Jumlah item yang tidak } \\
\text { memenuhi standar }\end{array}$ & $\begin{array}{c}\% \text { Tingkat } \\
\text { produk yang } \\
\text { tidak } \\
\text { memenuhi } \\
\text { standar }\end{array}$ \\
\hline Januari & 45 & 1 & $2,2 \%$ \\
\hline Februari & 36 & 1 & $2,8 \%$ \\
\hline Maret & 36 & 2 & $5,6 \%$ \\
\hline April & 54 & 2 & $3,7 \%$ \\
\hline Mei & 45 & 1 & $2,2 \%$ \\
\hline Juni & 54 & 1 & $1,9 \%$ \\
\hline Juli & 36 & 1 & $2,8 \%$ \\
\hline Agustus & 54 & 2 & $3,7 \%$ \\
\hline September & 36 & 1 & $2,8 \%$ \\
\hline Rata-rata & 44,0 & 1,3 & $3,1 \%$ \\
\hline
\end{tabular}

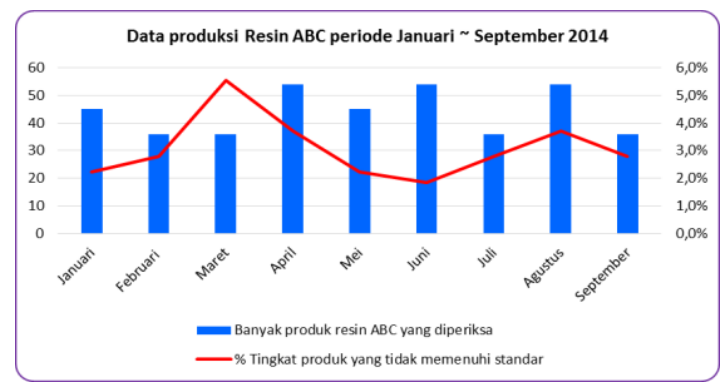

Terlihat bahwa terjadi defect pada resin $A B C$ rata-rata sebanyak 1,3\% tiap bulan. Hal ini pasti sangat tidak diinginkan oleh perusahaan karena menjadi kerugian yang sangat besar bagi perusahaan apalagi dilihat dari nilai uang yang dikeluarkan perusahaan. Sedangkan flow proses dapat dilihat dari diagram SIPOC berikut:

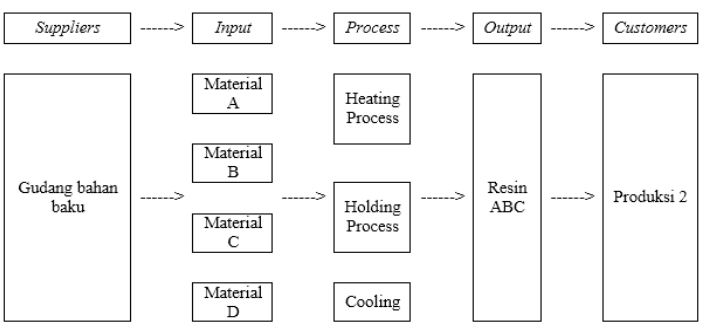

\subsection{Tahap Measure}

Measuremerupakan tahap pengevaluasian sistem pengukuran dan menaksir kemampuan baseline kinerja (output) dari perusahaan PT. Pardic Jaya Chemicals. Tahap measure ini terdiri dari dua langkah yaitu:

1. Menetapkan karakteristik kualitas kunci (CTQ)

Karakteristik-karakteristik kunci yang dapat menyebabkan hasil produksi resin $A B C$ tidak dapat memenuhi harapan pelanggan adalah sebagai berikut:
a. $\mathrm{OH}$-Valuetinggi
b. Colortinggi
c. Water Content tinggi

\begin{tabular}{|c|c|c|c|c|}
\hline Bulan & $\begin{array}{l}\text { Banyak item } \\
\text { resin } A B C \text { yang } \\
\text { diperiksa }\end{array}$ & $\begin{array}{l}\text { Jumlah item resin } \\
\text { ABC cacat }\end{array}$ & $\begin{array}{c}\text { Banyak } \\
\text { CTQ } \\
\text { potensial } \\
\text { penyebab } \\
\text { kecacatan }\end{array}$ & $\begin{array}{c}\text { Deskripsi } \\
\text { CTQ } \\
\text { potensial }\end{array}$ \\
\hline Januari & 45 & 1 & 1 & $\begin{array}{c}\text { OH-Value } \\
\text { tinggi }\end{array}$ \\
\hline Februari & 36 & 1 & 1 & $\begin{array}{c}\text { OH-Value } \\
\text { tinggi }\end{array}$ \\
\hline Maret & 36 & 2 & 2 & $\begin{array}{l}\text { OH-Value } \\
\text { tinggi, } \\
\text { Color } \\
\text { tinggi }\end{array}$ \\
\hline April & 54 & 2 & 1 & $\begin{array}{c}\text { OH-Value } \\
\text { tinggi }\end{array}$ \\
\hline Mei & 45 & 1 & 1 & $\begin{array}{c}\text { OH-Value } \\
\text { tinggi }\end{array}$ \\
\hline Juni & 54 & 1 & 1 & $\begin{array}{c}\text { OH-Value } \\
\text { tinggi }\end{array}$ \\
\hline Juli & 36 & 1 & 1 & $\begin{array}{c}\text { OH-Value } \\
\text { tinggi }\end{array}$ \\
\hline Agustus & 54 & 2 & 2 & $\begin{array}{l}\text { OH-Value } \\
\text { tinggi, } \\
\text { Water } \\
\text { content } \\
\text { tinggi }\end{array}$ \\
\hline September & 36 & 1 & 1 & $\begin{array}{c}\text { OH-Value } \\
\text { tinggi }\end{array}$ \\
\hline
\end{tabular}

Dari tabel diatas dapat diketahui bahwa ada tiga karakteristik kualitas kunci (CTQ) dalam proses produksi resin $A B C$ selama periode Januari sampai dengan September, banyak CTQ potensial yang terjadi didominasi oleh kecacatan karena $\mathrm{OH}$-Value tinggi. Hal ini dapat terlihat pada bulan Januari ada satu cacat karena $\mathrm{OH}$-Value tinggi, bulan Februari ada satu kecacatan potensial $\mathrm{OH}$ Value tinggi, bulan Maret ada dua kecacatan potensial $\mathrm{OH}$-Value tinggi dan Color tinggi, bulan April ada satu kecacatan potensial $\mathrm{OH}$ Value tinggi, bulan Mei ada satu kecacatan potensial $\mathrm{OH}$-Value tinggi, bulan Juni ada satu kecacatan potensial $\mathrm{OH}$-Valuetinggi, bulan Juli ada satu kecacatan potensial $\mathrm{OH}$ Valuetinggi, bulan Agustus ada dua kecacatan potensial $\mathrm{OH}$-Value tinggi dan Water content tinggi, sedangkan bulan September ada satu kecacatan potensial $\mathrm{OH}$-Value tinggi. 
2. Melakukan pengukuran kinerja output (produk resin $\mathrm{ABC}$ )

Pengukuran kinerjaoutput dilakukan dengan cara menghitung data hasil pemeriksaan hasil proses pembuatan resin $A B C$ serta menghitung DPMO dan nilai sigma PT. Pardic Jaya Chemicals, seperti tabel berikut:

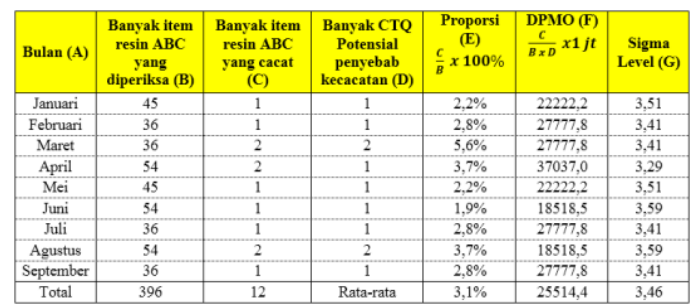

Tabel Konversi Sigma

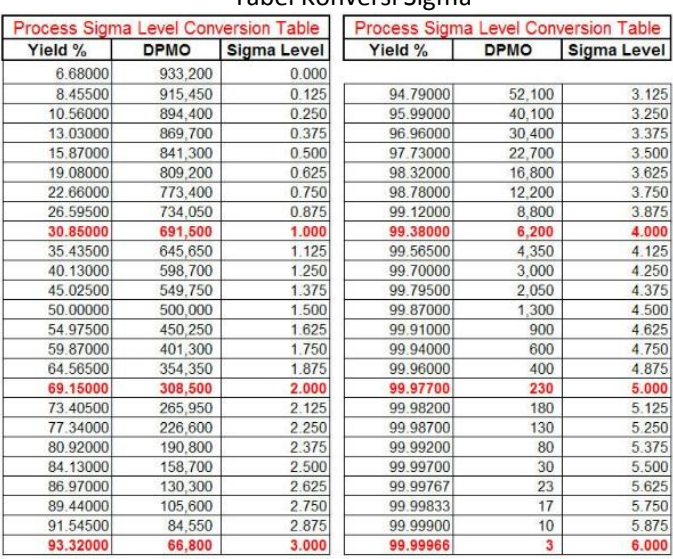

Berdasarkan dari hasil perhitungan diatas, maka dapat dinyatakan bahwa PT. Pardic Jaya Chemicals memiliki tingkat sigma sebesar 3,46 dengan DPMO rata-rata sebesar 25514,4 per sejuta produk resin ABC. Perusahaan dapat melakukan pengukuran output tentang jenis kecacatan yang ditentukan sehingga dapat diketahui kapabilitas sigma dan DPMO perusahaan saat ini, kemudian perusahaan harus melakukan perbaikan-perbaikan untuk mengurangi jumlah kecacatan produk dengan metode six sigma sehingga dapat mengurangi jumlah defect/cacat yang sering terjadi.

\subsection{TahapAnalyze}

Tahap analyze dilakukan untuk mengidentifikasi masalah dan menemukan sumber penyebab masalah kualitas. Tahap ini terdiri atas dua langkah yaitu:

1. Analisa stabilitas dan kapabilitas (kemampuan) proses

Dalam melakukan analisis kapabilitas proses terdapat dua langkah berikut, yaitu:

a) Menghitung frekuensi dari setiap CTQ yang kemudian hasilnya dituliskan ke dalam tabel, sebagai berikut:

\begin{tabular}{|c|l|c|c|c|c|}
\hline No & Jenis Kecacatan & $\begin{array}{c}\text { Frekuensi } \\
\text { Kecacatan }\end{array}$ & $\begin{array}{c}\text { Frekuensi } \\
\text { Kumulatif } \\
\text { Kecacatan }\end{array}$ & $\begin{array}{c}\text { Persentase } \\
\text { dari total } \\
\text { cacat (\%) }\end{array}$ & $\begin{array}{c}\text { Persentase } \\
\text { Kumulatif } \\
(\%)\end{array}$ \\
\hline 1 & OH Value Tinggi & 10 & 10 & 83,33 & 83,33 \\
\hline 2 & $\begin{array}{l}\text { Water Content } \\
\text { Tinggi }\end{array}$ & 1 & 11 & 8,33 & 91,67 \\
\hline 3 & Color Tinggi & 1 & 12 & 8,33 & 100,00 \\
\hline & Total & 12 & & 100,00 & \\
\hline
\end{tabular}

b) Menggunakan hasil perhitungan ke dalam diagram Pareto

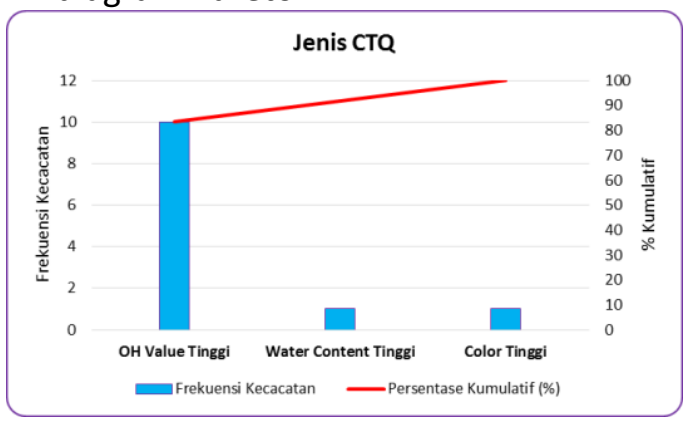

c) Data dan controlchart proses
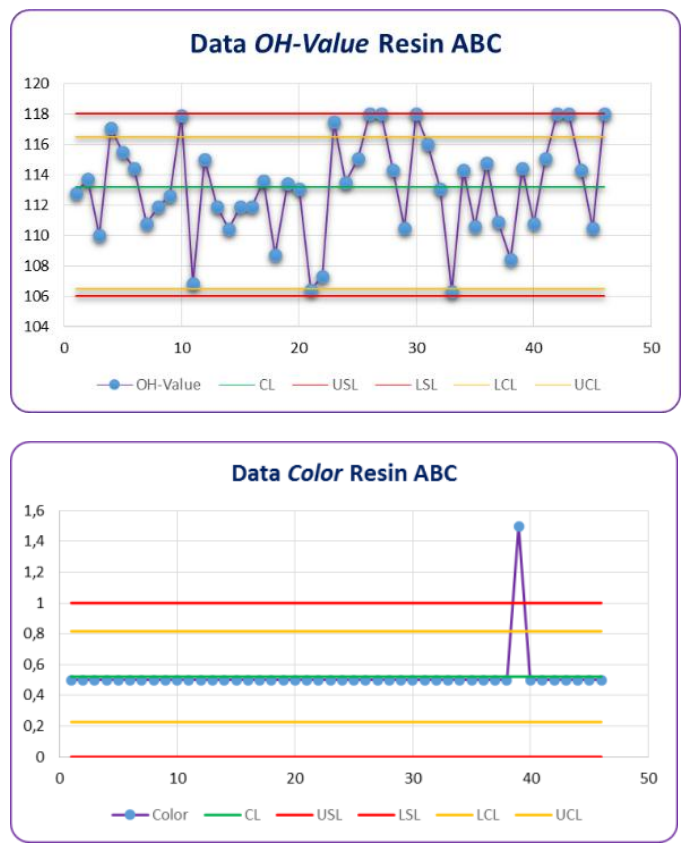


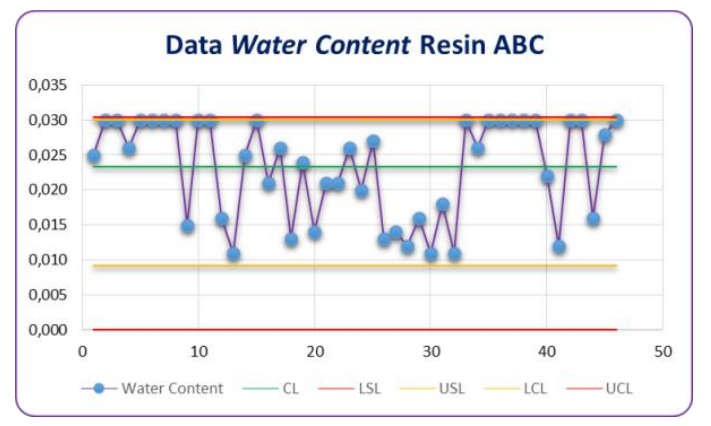

d) Menghitung Kapabilitas Proses (Cp) \& Cpk menggunakan software Minitab
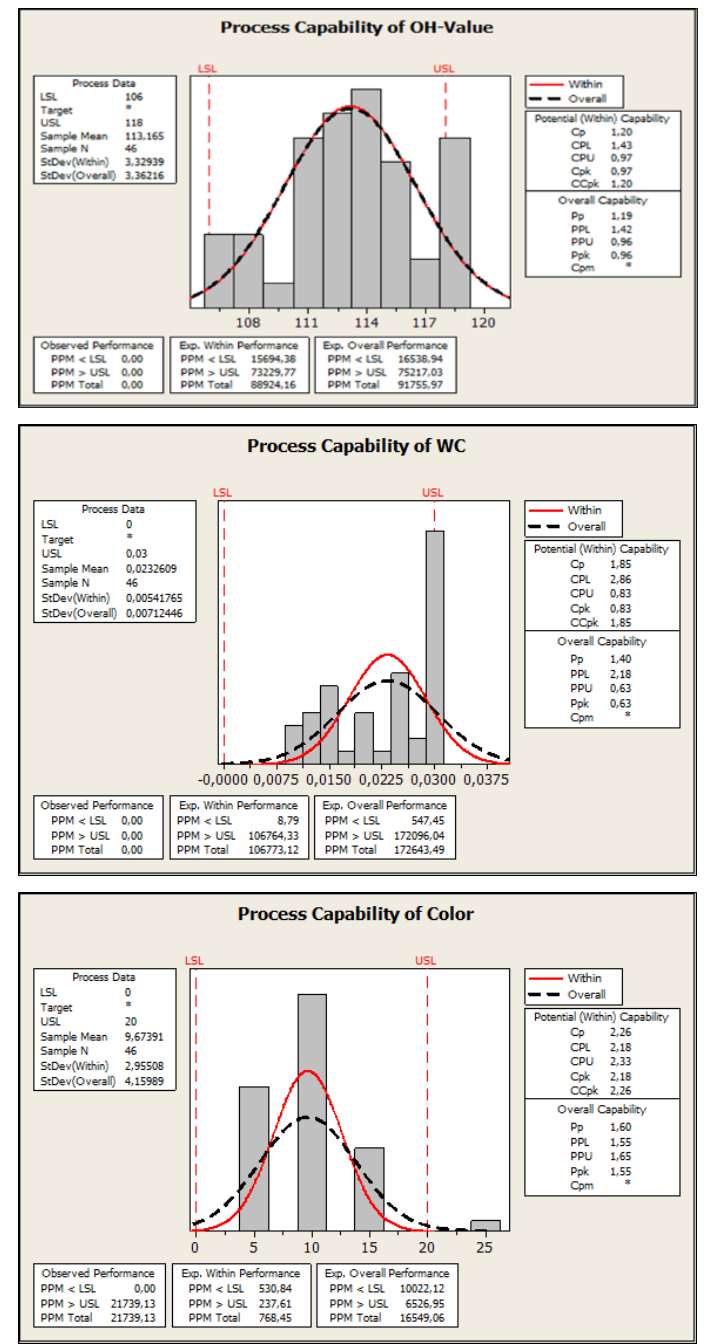

Berdasarkan tabel dan gambar diatas, dapat diketahui rincian tidak terpenuhinya jenis CTQ yang pada akhirnya mengakibatkan terjadinya produk cacat di PT. Pardic Jaya Chemicals. Dari diagram pareto dapat langsung dilihat bahwa jenis dan jumlah kecacatan terbesar pada resin $A B C$ yaitu diakibatkan oleh hasil $\mathrm{OH}$-Value yang tinggi sebesar 10 kecacatan sedangkan tabel 4.4 dapat diketahui jumlah persentase dari kecacatan sebesar $83,33 \%$ dari total kecacatan. Jenis kecacatan kedua adalah color tinggi sebanyak 1 kecacatan dengan persentase sebesar $8,33 \%$ dan jenis kecacatan ketiga adalah watercontent tinggi sebanyak 1 kecacatan dengan persentase sebesar 8,33\%. Pada kenyataannya di PT. Pardic Jaya Chemicals untuk proses pembuatan resin $X$ yang menggunakan resin $A B C$ sebagai bahan baku ada beberapa yang juga harus mengalami kegagalan karena penanganan yang kurang tepat. Maka dari itu dibutuhkan cara untuk menanggulangi jenis-jenis kecacatan yang terjadi pada resin $A B C$ agar tidak berlanjut pada terjadinya kecacatan lain saat proses pembuatan resin $\mathrm{X}$.

Sedangkan pada perhitungan menggunakan minitab dapat diketahui nilai $\mathrm{Cp} \& \mathrm{Cpk}$ dengan menggunakan software Minitab bahwa untuk $\mathrm{OH}$-Value mempunyai $\mathrm{Cp}$ dan $\mathrm{Cpk}$ sebesar 1,20 dan 0,97. Untuk watercontent sebesar 1,85 dan 0,83 sedangkan untuk color adalah sebesar 2,26 dan 2,18. Hal ini menandakan bahwa $\mathrm{OH}$-Value adalah proses yang paling tidak capablekarena $\mathrm{Cp}<1,33$.

2. Mengidentifikasi sumber-sumber dan akar masalah penyebab kualitas

\begin{tabular}{|c|c|c|c|c|c|c|c|}
\hline \multirow{2}{*}{ No } & \multirow{2}{*}{ Jenis Kecacatan } & \multicolumn{5}{|c|}{ Faktor Penyebab Kecacatan } & \multirow{2}{*}{ Total } \\
\hline & & Man & Material & Method & Machine & Media & \\
\hline \multirow{2}{*}{1} & \multirow{2}{*}{ OH-Value Tinggi } & 2 & 0 & 8 & 0 & 0 & 10 \\
\hline & & $16,67 \%$ & $0 \%$ & $66,67 \%$ & $0 \%$ & $0 \%$ & $83,33 \%$ \\
\hline \multirow{2}{*}{2} & \multirow{2}{*}{ Color Tinggi } & 0 & 1 & 0 & 0 & 0 & 1 \\
\hline & & $0 \%$ & $8,33 \%$ & $0 \%$ & $0 \%$ & $0 \%$ & $8,33 \%$ \\
\hline \multirow{2}{*}{3} & \multirow{2}{*}{$\begin{array}{l}\text { Water Content } \\
\quad \text { Tinggi }\end{array}$} & 0 & 0 & 1 & 0 & 0 & 1 \\
\hline & & $0 \%$ & $0 \%$ & $8,33 \%$ & $0 \%$ & $0 \%$ & $8,33 \%$ \\
\hline \multirow{2}{*}{\multicolumn{2}{|c|}{ Total }} & 2 & 1 & 9 & 0 & 0 & 12 \\
\hline & & $16,67 \%$ & $8,33 \%$ & $75,00 \%$ & $0,00 \%$ & $0,00 \%$ & $100 \%$ \\
\hline
\end{tabular}

Setelah melakukan penghitungan pada tabel diatas maka selanjutnya hasil dari perhitungan diatas tersebut dituangkan pada diagram sebab akibat (Fish Bone) seperti gambar berikut: 


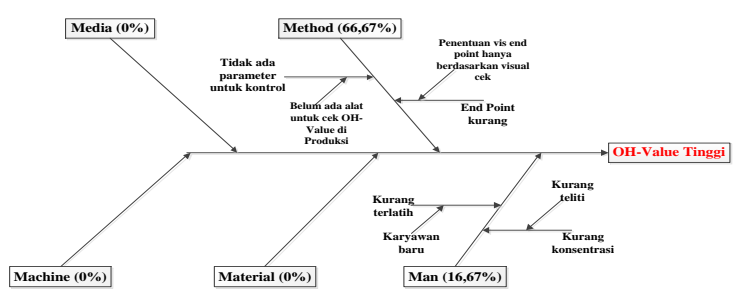

Gambar fishboneOH-Value tinggi

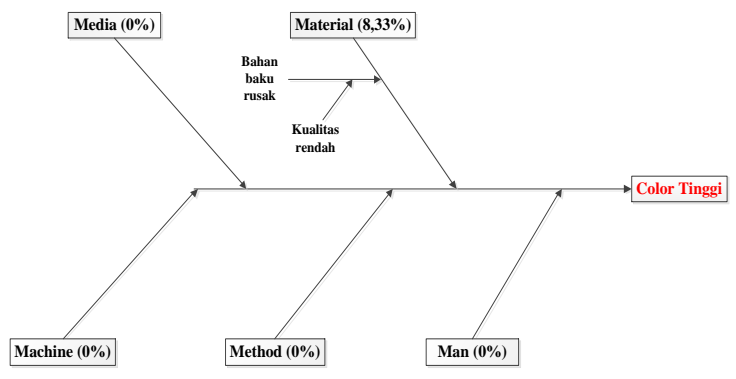

Gambar fishboneColor tinggi

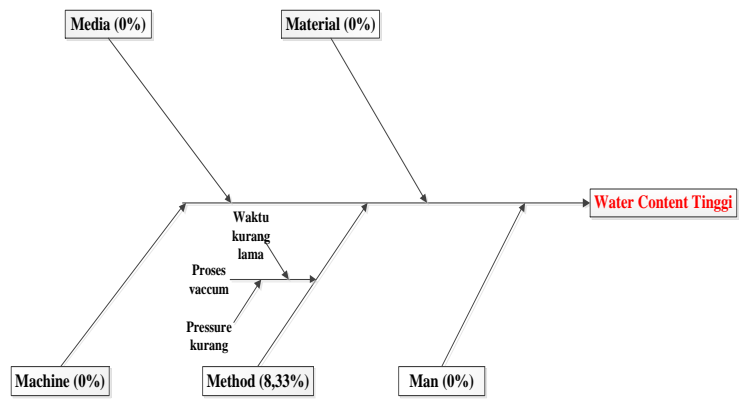

Gambar fishboneWater Content tinggi

Dari tabel dan diagram sebab akibat diatas, dapat diketahui bahwa faktor penyebab kecacatan tertinggi ada pada unsur Method, yaitu sebesar 75\%. Methoddapat menjadi penyebab kecacatan hasil pembuatan resin $A B C$ dikarenakan beberapa faktor, yaitu:

1. Tidak/belum adanya parameter untuk kontrol $\mathrm{OH}$-Value saat proses pembuatan resin $A B C$ sehingga menyulitkan operator untuk menentukan endpoint yang tepat sebelum cooling karena produksi tidak mempunyai alat untuk cek $\mathrm{OH}$ value.
2. Endpoint viskositas kurang juga merupakan salah satu penyebab $\mathrm{OH}$-Value menjadi tinggi karena penentuan endpoint viskositas menggunakan viskometer gardner yang pengecekannya adalah secara visual sehingga persepsi masingmasing operator pasti berbeda.

Faktor kedua penyebab kecacatan adalah Man, yaitu sebesar 16,67\%. Manusia dapat menjadi penyebab kecacatan pembuatan resin $A B C$ dikarenakan beberapa faktor, antar lain:

1. Karyawan bekerja kurang konsentrasi, hal ini sering menyebabkan ketelitian pekerjaan karyawan menjadi berkurang.

2. Karyawan belum memiliki skill/kemampuan yang cukup karena karyawan tersebut merupakan karyawan baru yang masih perlu bimbingan dan belajar.

Faktor ketiga penyebab kecacatan adalah Material, yaitu sebesar 8,33\%. Penyebabnya adalah kurangnya kontrol terhadap penanganan bahan baku yang akan dipakai untuk produksi. Karena ada beberapa jenis bahan baku yang perlu penanganan khusus sebelum dipastikan bahan baku itu layak pakai. Dari tiga faktor itulah penyebab dominan terjadinya kecacatan pada proses pembuatan resin $A B C$.

\subsection{Tahap Improve}

Pada tahapan ini yang dilakukan adalah menetapkan rencana-rencana tindakan untuk melaksanakan peningkatan kualitas menggunakan metode Six Sigma, berdasarkan 5W-1H (WHAT-tujuan utama, WHYalasan, WHERE-lokasi, WHEN-waktu, WHOorang, HOW-metode). Rencana tindakan/ usulan-usulan pada faktor man, material, method untuk masing-masing jenis kecacatan dapat dilihat pada beberapa tabel berikut: 
a. Tabel perbaikan masalah $\mathrm{OH}$-Value tinggi prinsip $5 \mathrm{~W}-1 \mathrm{H}$

\begin{tabular}{|c|c|c|}
\hline Jenis & $5 W-1 H$ & Deskripsi Rencana Perbaikan \\
\hline $\begin{array}{l}\text { Tujuan } \\
\text { utama }\end{array}$ & $\begin{array}{l}\text { What } \\
\text { (Apa) }\end{array}$ & $\begin{array}{l}\text { Menetapkan prosedur kerja bagi karyawan } \\
\text { bagian produksi }\end{array}$ \\
\hline $\begin{array}{c}\text { Alasan } \\
\text { Kegunaan }\end{array}$ & $\begin{array}{c}\text { Why } \\
\text { (Mengapa) }\end{array}$ & $\begin{array}{l}\text { Agar proses produksi sesuai dengan prosedur } \\
\text { kerja yang telah ditetapkan sehingga } \\
\text { menghasilkan produk yang sesuai spesifikasi }\end{array}$ \\
\hline Lokasi & $\begin{array}{l}\text { Where } \\
\text { (Dimana) }\end{array}$ & $\begin{array}{l}\text { Dilaksanakan di PT. Pardic Jaya Chemicals, } \\
\text { tepatnya di ruang produksi dan ruang untuk } \\
\text { pelatihan karyawan }\end{array}$ \\
\hline $\begin{array}{l}\text { Sekuens } \\
\text { (Urutan) }\end{array}$ & $\begin{array}{l}\text { When } \\
\text { (Kapan) }\end{array}$ & Pada saat stop proses produksi (dayshift) \\
\hline Orang & $\begin{array}{l}\text { Who } \\
\text { (Siapa) }\end{array}$ & $\begin{array}{l}\text { Tanggung jawab diserahkan kepada kepala } \\
\text { bagian produksi }\end{array}$ \\
\hline Metode & $\begin{array}{c}\text { How } \\
\text { (Bagaimana) }\end{array}$ & $\begin{array}{l}\text { 1. Melakukan percobaan penentuan endpoint } \\
\text { menggunakan viskometer Cone \& Plate } \\
\text { 2. Standarisasi hasil percobaan } \\
\text { 3. Memberikan pelatihan kepada karyawan } \\
\text { agar dapat menghasilkan produk yang baik }\end{array}$ \\
\hline
\end{tabular}

b. Tabel perbaikan masalah Water Content tinggi prinsip $5 \mathrm{~W}-1 \mathrm{H}$

\begin{tabular}{|c|c|c|}
\hline Jenis & $5 \mathrm{~W}-1 \mathrm{H}$ & Deskripsi Rencana Perbaikan \\
\hline $\begin{array}{l}\text { Tujuan } \\
\text { utama }\end{array}$ & $\begin{array}{l}\text { What } \\
\text { (Apa) }\end{array}$ & $\begin{array}{l}\text { Menetapkan prosedur kerja bagi karyawan } \\
\text { bagian produksi }\end{array}$ \\
\hline $\begin{array}{c}\text { Alasan } \\
\text { Kegunaan }\end{array}$ & $\begin{array}{c}\text { Why } \\
\text { (Mengapa) }\end{array}$ & $\begin{array}{l}\text { Agar proses produksi sesuai dengan prosedur } \\
\text { kerja yang telah ditetapkan sehingga } \\
\text { menghasilkan produk yang sesuai spesifikasi }\end{array}$ \\
\hline Lokasi & $\begin{array}{l}\text { Where } \\
\text { (Dimana) }\end{array}$ & $\begin{array}{l}\text { Dilaksanakan di PT. Pardic Jaya Chemicals, } \\
\text { tepatnya di ruang produksi dan ruang untuk } \\
\text { pelatihan karyawan }\end{array}$ \\
\hline $\begin{array}{l}\text { Sekuens } \\
\text { (Urutan) }\end{array}$ & $\begin{array}{l}\text { When } \\
\text { (Kapan) }\end{array}$ & Pada saat proses produksi \\
\hline Orang & $\begin{array}{l}\text { Who } \\
\text { (Siapa) }\end{array}$ & $\begin{array}{l}\text { Tanggung jawab diserahkan kepada kepala } \\
\text { bagian produksi }\end{array}$ \\
\hline Metode & $\begin{array}{c}\text { How } \\
\text { (Bagaimana) }\end{array}$ & $\begin{array}{l}\text { 1. Menambah waktu holding vaccum dengan } \\
\text { asumsi dapat mengambil kadar air yang } \\
\text { tertinggal saat akhir reaksi } \\
\text { 2. Standarisasi petunjuk kerja } \\
\text { 3. Memberikan pelatihan kepada karyawan } \\
\text { agar dapat menghasilkan produk yang baik }\end{array}$ \\
\hline
\end{tabular}

Tabel perbaikan masalah Color tinggi prinsip 5W-1H

\begin{tabular}{|c|c|c|}
\hline Jenis & $5 W-1 H$ & Deskripsi Rencana Perbaikan \\
\hline $\begin{array}{l}\text { Tujuan } \\
\text { utama }\end{array}$ & $\begin{array}{l}\text { What } \\
\text { (Apa) }\end{array}$ & $\begin{array}{l}\text { Menentukan bahan baku untuk resin } \mathrm{ABC} \\
\text { secara tepat dan berkualitas }\end{array}$ \\
\hline $\begin{array}{c}\text { Alasan } \\
\text { Kegunaan }\end{array}$ & $\begin{array}{c}\text { Why } \\
\text { (Mengapa) }\end{array}$ & $\begin{array}{l}\text { Agar bahan baku sesuai dengan standar yang } \\
\text { telah ditetapkan perusahaan sehingga } \\
\text { menghasilkan produk yang sesuai spesifikasi }\end{array}$ \\
\hline Lokasi & $\begin{array}{l}\text { Where } \\
\text { (Dimana) }\end{array}$ & $\begin{array}{l}\text { Dilaksanakan di PT. Pardic Jaya Chemicals, } \\
\text { tepatnya di bagian penerimaan barang }\end{array}$ \\
\hline $\begin{array}{l}\text { Sekuens } \\
\text { (Urutan) }\end{array}$ & $\begin{array}{l}\text { When } \\
\text { (Kapan) }\end{array}$ & Pada saat bahan baku dikirim oleh supplier \\
\hline Orang & $\begin{array}{l}\text { Who } \\
\text { (Siapa) }\end{array}$ & $\begin{array}{l}\text { Tanggung jawab diserahkan kepada bagian } \\
\text { quality control (penerimaan RM) }\end{array}$ \\
\hline Metode & $\begin{array}{c}\text { How } \\
\text { (Bagaimana) }\end{array}$ & $\begin{array}{l}\text { Mengadakan penjelasan tentang pentingnya } \\
\text { pemeriksaan bahan baku terlebih dahulu agar } \\
\text { memudahkan kontrol bahan baku yang akan } \\
\text { dipakai proses saat produksi, menetapkan } \\
\text { standar kualitas bahan baku }\end{array}$ \\
\hline
\end{tabular}

\subsection{TahapControl}

Rencana tindakan perbaikan yang dilakukan di PT. Pardic Jaya Chemicals akan dilaksanakan dalam jangka waktu satu tahun sehingga dapat mencapai target yang diinginkan perusahaan. Target yang ingin dicapai perusahaan yaitu mengurangi produk offgrade/outspec tidak lebih dari $1 \%$ dari jumlah produksi yang dihasilkan. Setelah melaksanakan rencana tindakan, perlu adanya perencanaan yang berupa alat kontrol untuk mengetahui apakah ada peningkatan kualitas pembuatan resin ABC. Tabel untuk mengontrol perencanaan yang telah dilakukan dapat dilihat pada tabel berikut ini:

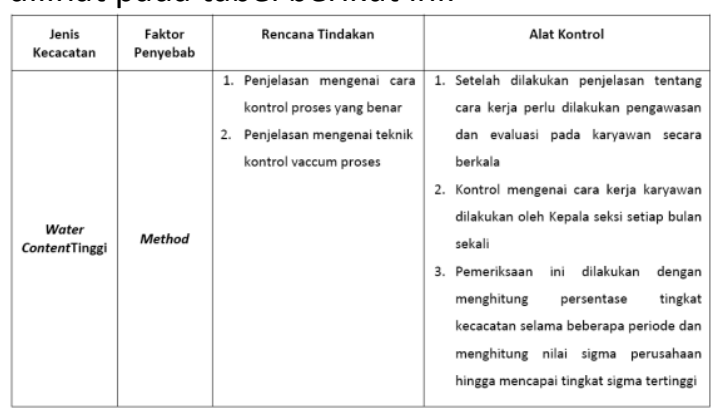




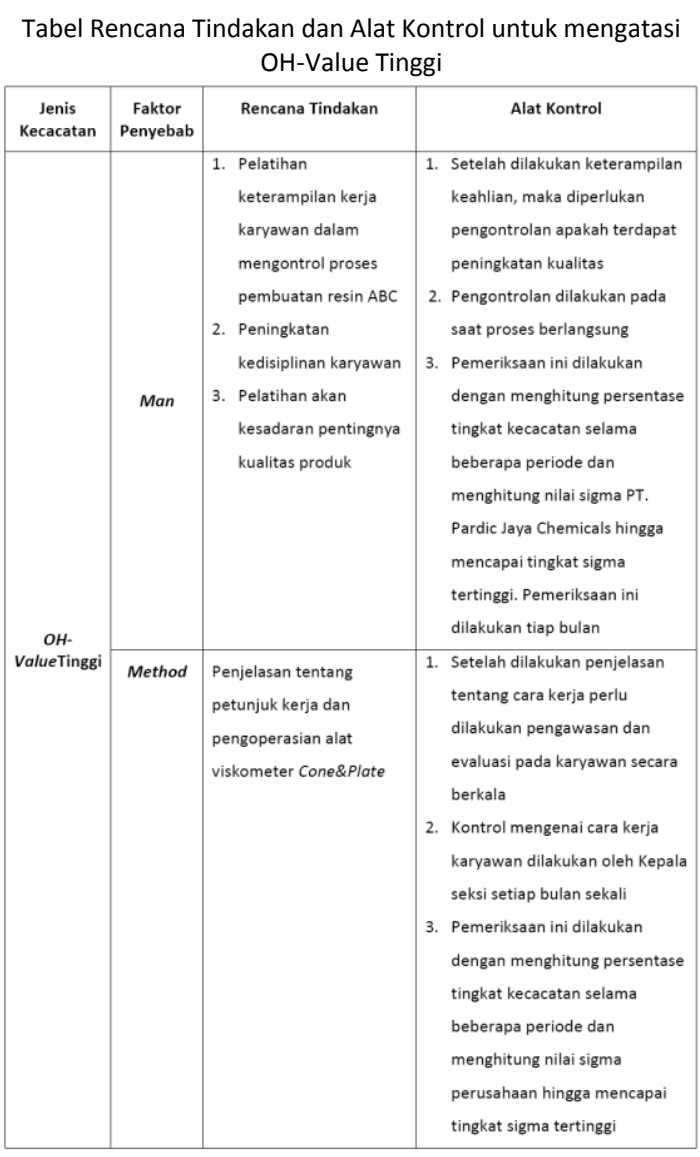

Tabel rencana Tindakan dan Alat Kontrol untuk mengatasi Water Content Tinggi

\begin{tabular}{|c|c|c|c|}
\hline $\begin{array}{c}\text { Jenis } \\
\text { Kecacatan }\end{array}$ & $\begin{array}{c}\text { Faktor } \\
\text { Penyebab }\end{array}$ & Rencana Tindakan & Alat Kontrol \\
\hline ColorTinggi & Material & $\begin{array}{l}\text { 1. Pemeriksaan yang } \\
\text { lebih efektif terhadap } \\
\text { bahan baku sebelum } \\
\text { proses produksi } \\
\text { 2. Penggunaan bahan } \\
\text { baku yang baik (tidak } \\
\text { melebihi shelflife / } \\
\text { kadaluwarsa) }\end{array}$ & $\begin{array}{l}\text { 1. Pengawasan dan } \\
\text { pengevaluasian kualitas } \\
\text { bahan baku dari supplier } \\
\text { pada saat barang tiba } \\
\text { 2. Pemeriksaan ini } \\
\text { dilakukan dengan } \\
\text { menghitung persentase } \\
\text { tingkat cacat beberapa } \\
\text { periode dan menghitung } \\
\text { nilai sigma perusahaan } \\
\text { hingga mencapai tingkat } \\
\text { sigma tertinggi }\end{array}$ \\
\hline
\end{tabular}

Rencana hasil tindakan diatas perlu dilakukan untuk peningkatan kualitas pembuatan resin $A B C$. Hal-hal yang perlu diperhatikan oleh PT. Pardic Jaya Chemicals dalam mengontrol semua rencana tindakan yang telah dilaksanakan adalah sebagai berikut:
1. Secara berkala (setiap 1 atau 2 bulan sekali) menghitung data hasil pembuatan resin $A B C$ yang cacat kemudian menghitung persentase tingkat kecacatannya.

2. Mencari potensial penyebab timbulnya kecacatan pembuatan resin $A B C$.

3. Menghitung DPMO dan nilai sigma untuk melihat peningkatan nilai sigma, dan seterusnya dilakukan perhitungan untuk dapat mencapai level 6 sigma dengan melebihi pencapaian sigma level sebesar 3,46 dan DPMO sebesar 25514,4. Setelah peningkatan kualitas six sigma berhasil, maka hasil-hasil yang telah tercapai dari tindakan peningkatan kualitas harus distandarisasi dan didokumentasikan.

\section{KESIMPULAN \& SARAN}

\subsection{Kesimpulan}

Dari hasil analisis penelitian yang telah dilakukan dapat disimpulkan bahwa perusahaan PT. Pardic Jaya Chemicals sampai sekarang masih belum menerapkan six sigma secara keseluruhan karena memang metode six sigma belum dipakai di PT. Pardic Jaya Chemicals. Namun metode six sigma dapat dipakai sebagai metode pembanding untuk improvement yang lebih baik. Untuk penerapan konsep secara sederhana dapat dikatakan bahwa perusahaan belum mampu mencapai target yang telah ditetapkan yaitu tidak lebih $1 \%$ produk cacat dari jumlah produksi perbulan. Hal ini terjadi karena perusahaan belum melakukan program perencanaan six sigma secara keseluruhan. Kesimpulannya adalah sebagai berikut:

1. Berdasarkan data produksi yang diperoleh dari PT. Pardic Jaya Chemicals diketahui jumlah produksi resin $A B C$ dari bulan Januari sampai September 2014 adalah sebanyak 396 item yang diperiksa dengan jumlah item cacat terjadi 12 item. Berdasarkan perhitungan, PT. Pardic Jaya Chemicals memiliki tingkat 
sigma 3,46 dengan kemungkinan 25514,4 untuk sejuta produksi (DPMO). Kapabilitas proses yang dicapai untuk masing-masing item yang masih terdapat kecacatan didalamnya adalah sebagai berikut Cp\&CpkOH-Value 1,20 \& 0,97 . Cp\&Cpkwatecontent $1,85 \& 0,83$. Sedangkan Cp\&Cpkcolor 2,26 \& 2,18. $\mathrm{Hal}$ ini tentunya menjadi sebuah kerugian yang sangat besar apabila tidak ditangani sebab semakin banyak produk yang gagal dalam proses produksi tentunya mengakibatkan pembengkakan biaya produksi. Jadi secara prinsip, six sigma dapat diterapkan untuk merencanakan pengendalian kualitas.

2. Jenis-jenis kerusakan yang sering terjadi pada produksi resin $A B C$ yaitu disebabkan karena $\mathrm{OH}$-Valuetinggi sebanyak 10 kali, watercontent tinggi sebanyak 1 kali, serta jenis cacat berupa color tinggi sebanyak 1 kali. Atau dengan kata lain CTQ (CriticaltoQuality) yang terjadi adalah $83,33 \%$ adalah $\mathrm{OH}$-Value tinggi, $8,33 \%$ watercontent tinggi, dan 8,33\% adalah color tinggi. Faktor penyebab $16,67 \%$ pada faktor man\& $66,67 \%$ pada faktor methoduntuk $\mathrm{OH}$-Value. Faktor penyebab pada faktor method8,33\% untukwatercontent, dan faktor penyebab pada faktor material $8,33 \%$ untuk color.

3. Six sigma merupakan metode dan konsep yang tepat untuk dipadukan dengan sistem Total Quality Control yang selama ini sudah diterapkan di PT. Pardic Jaya Chemicals karena secara detail bisa diaplikasikan untuk mencari penyebab defect/cacat yang terjadi hingga menghitung tingkat kemungkinan kecacatan setiap sejuta peluang serta melakukan improvisasi terhadap permasalahan defect yang sering terjadi.

Pada tahap akhir yaitu control, dilakukan rencana tindakan dan alat kontrolnya pada masing-masing kecacatan. Rencana tindakan- nya adalah berupa pelatihan ketrampilan karyawan dalam proses produksi resin $A B C$, peningkatan kedisiplinan karyawan, pelatihan karyawan untuk penggunaan alat baru. Sedangkan alat kontrol diperlukan untuk dapat mengetahui bahwa terjadi peningkatan kualitas atau tidak.

\subsection{Saran}

Saran yang dapat diberikan kepada PT. Pardic Jaya Chemicals adalah perusahaan perlu menerapkan rencana pengendalian kualitas sebelum melakukan produksi yaitu dengan cara:

1. Perusahaan harus dapat memberikan pengarahan kepada karyawannya tentang pentingnya kualitas produk resin $A B C$ dan meningkatkan disiplin kerja karyawannya.

2. Pimpinan Produksi harus sering melakukan kontrol terhadap semua hal yang menyangkut proses produksi khususnya pada tahapan analisa.

3. PT. Pardic Jaya Chemicals hendaklah lebih memperketat standar kualitas bahan baku yang nantinya akan dijadikan patokan untuk proses produksi.

4. Perusahaan harus dapat memberikan pelatihan kepada karyawan agar dapat menghasilkan produk yang berkualitas.

5. Pimpinan harus dapat membuat peningkatan pada kinerja para karyawan dengan cara menciptakan lingkungan kerja yang kondusif.

\section{DAFTAR PUSTAKA}

Yamit, Z. (2013). Manajemen Kualitas Produk \& Jasa. Yogyakarta: Ekonisia.

Evans, J.R. \& Lindsay, W.M. (2007). Pengantar Six Sigma AnIntroductionto Six Sigma \& Process Improvement. Singapore: South Western.

Pande, P.S., Neuman, R.P., \& Cavanagh, R.R. 
(2000). The Six Sigma Way. NewYork: McGraw-HillCompanies.

Hendradi, C.T. (2006). Statistik Six Sigma dengan Minitab. Yogyakarta: Andi Offset.

Pzydek, T. (2003).The Six Sigma Handbook. New York: McGraw-HillCompanies.

(Dari Buku)

Sudianto, M.D. (2008). Penggunaan Metode Six Sigma dalam Perencanaan Pengendalian Kualitas pada U.D.Global Info Media di Ungaran, Skripsi, Jurusan Manajemen FE Universitas Katholik Soegijapranata, Semarang

(Dari Skripsi)

Vitho dkk. (2013). Aplikasi Six Sigma untuk menganalisis faktor-faktor penyebab kecacatan produk Crumb Rubber SIR 20 pada PT. XYZ, DMAIC-FMEA, Kecacatan kadar PRI sebesar 70,42\%.

Hariri dkk. (2013). Penerapan metode Six Sigma sebagai upaya perbaikan untuk mengurangi Packdefect susu Greenfields (Studi kasus pada PT. Greenfield Malang), DMAIC-FMEA, RPN terbesar pada mesin filling yaitu 320. 


\title{
ANALISA DAN PERANCANGAN SISTEM PARKIR PADA PT. KMK GLOBAL SPORTS
}

\author{
Irfan Nasrullah ${ }^{1)}$, Febri Lia Yuliana ${ }^{2)}$ \\ 1) Program Study Teknik Informatika Fakultas Teknik \\ Universitas Muhammadiyah Tangerang \\ E-mail: pengembara82@yahoo.co.id \\ 2) Program Study Sistem Informasi \\ STMIK Insan Pembangunan Tangerang \\ E-mail: febri.lia26@yahoo.com
}

\begin{abstract}
ABSTRAK
PT. KMK Global Sports merupakan salah satu perusahaan sepatu di Tangerang. Salah satu pelayanan perusahaan ini adalah masalah parkir kendaraan untuk karyawan dan tamu. Pelaksanaan sistem parkir pada PT. KMK Global Sports kurang maksimal karena belum adanya sistem terkomputerisasi untuk meningkatkan pelayanan yang baik. Metode perancangan yang digunakan adalah metode yang berorientasi objek melalui tahap pembuatan UML dan pembuatan database. Tujuan diadakan penelitian ini adalah untuk merancang sebuah sistem informasi parkir. Program yang digunakan dalam perancangan sistem ini menggunakan Power Builder sebagai bahasa pemrograman dan SQL server sebagai databasenya. Hasil penelitian menunjukan bahwa analisa dan perancangan sistem informasi parkir dapat memberikan informasi yang lebih cepat, tepat dan akurat. Dengan diperkenalkannya sistem ini maka diharapkan akan mempermudah dalam pelaksanaan sistem kerja yang sudah ada.
\end{abstract}

Kata Kunci: Parkir, Analisa, Perancangan, Sistem Informasi.

\section{PENDAHULUAN}

\subsection{Latar Belakang Masalsah}

Dewasa ini perusahaan-perusahaan baik besar maupun kecil telah berbondongbondong menggunakan bantuan ilmu pengetahuan dan tekhnologi dalam mendukung proses operasional perusahaan. Parkir merupakan suatu pendukung perkembangan sebuah institusi dimana sistem ini mempunyai peranan penting dalam menunjang kemajuan. Sistem parkir yang tertata rapi dengan mengedepankan keamanan dan kenyamanan akan membuat karyawan tidak perlu merasa khawatir terhadap keamanan kendaraannya. Sehingga mereka dapat bekerja dengan tenang tanpa terganggu akan kehilangan kendaraannya. Jumlah karyawan PT. KMK Global Sports saat ini \pm 12.000 karyawan, dengan jumlah karyawan yang menggunakan kendaraan bermotor \pm 4.000 karyawan. Area parkir pada PT. KMK Global Sports saat ini terdiri dari 3 lantai, dimana tiap lantainya memiliki luas $\pm 100 \mathrm{~m}^{2} \times 80 \mathrm{~m}^{2}$. Sistem parkir yang berjalan saat ini pada PT. KMK Global Sports saat ini menggunakan stiker motor untuk mengetahui bahwa karyawan tersebut sudah terdaftar sebagai karyawan PT. KMK Global Sports. Dimana sistem ini masih memiliki banyak kelemahan seperti stiker kendaraan bisa dengan mudah di perjual belikan di luar perusahaan. Dengan sistem ini ternyata 
masih belum menyelesaikan masalahmasalah yang terjadi sebelumnya seperti susahnya mencari area parkir yang kosong, berdesak-desakan saat memarkir kendaraan, penumpukan kendaraan diarea tertentu, karyawan sering tidak ingat dimana memarkir motornya, pengecakan surat-surat kendaraan di pintu keluar sehingga menyebabkan ketidaknyamanan.

Untuk mengatasi masalah diatas penulis merancang sebuah sistem parkir yang lebih baik. Dengan cara mendata ulang berapa jumlah karyawan yang menggunakan kendaraan bermotor, membagi area parkir menjadi beberapa blok dan tiap blok diisi oleh 12 kendaraan dan diberi nomor tiap bloknya. Pada saat input nomor id card karyawan akan secara otomatis akan muncul nik, nama dan plat nomor kendaraan.

\subsection{Batasan Masalah}

Berdasarkan rumusan masalah diatas, maka batasan masalah dalam penelitian ini adalah sebagai berikut:

Aplikasi ini hanya digunakan untuk pengelolaan parkir kendaraan bermotor.

a. Area parkir digunakan untuk karyawan yang sudah tercatat sebagai member.

b. Aplikasi ini menggunakan id card karyawan sebagi input masukan.

\subsection{Rumusan Masalah}

Perumusan masalah dalam penelitian ini sebagai berikut:

a. Bagaimana sistem perparkiran yang berjalan.

b. Bagaimana sistem yang dibutuhkan saat ini.

\subsection{Tujuan Penelitian}

Adapun tujuan dari penelitian ini yaitu:

a. Membantu mempermudah dan mempercepat proses pencarian lahan parkir.

b. Mengetahui informasi keluar masukannya kendaraan bermotor. c. Meningkatkan keamanan dan kenyamanan di area parkir.

\subsection{Manfaat Penelitian}

Manfaat dari penelitian ini adalah sebagai berikut:

a. Bagi mahasiswa:

Untuk meningkatkan dan mengembangkan pola pikir penulis, sehingga dapat mengaktualisasikan pengetehuan yang diterima penulis di bangku kuliah ke dalam kenyataan yang penulis temui di tempat penelitian.

b. Bagi perusahaan:

Untuk mendapatkan sistem baru yang terkomputerisasi sesuai dengan kondisi dan perkebanga perusahaan saat ini.

c. Bagi Akademik:

Sebagai pembuktian bahwa Mahasiswa dapat mengaktualisasikan pengetahuan yang diterima selama di bangku kuliah ke dalam kenyataan yang Mahasiswa temui di tempat penelitian.

\section{LANDASAN PEMIKIRAN}

\subsection{Pengertian sistem}

Menurut Raymond McLeod, Jr., George P.Schell diterjemahkan oleh Ali Akbar Yulianto (2010: 10), Sistem Informasi adalah suatu sistem virtual yang memungkinkan manajemen mengendalikan operasi sistem fisik perusahaan pada suatu jaringan kerja dari prosedur-prosedur yang saling berhubungan, berkumpul bersama-sama untuk melakukan suatu kegiatan atau untuk menyelesaikan suatu sasaran yang tertentu, dalam suatu urut-urtan operasi klerikal (tulis menulis) biasanya melibatkan beberapa orang didalam satu atau lebih departemen, yang diterapkan untuk menjamin penanganan yang seragam dari transaksi bisnis yang terjadi.

Menurut Kenneth E. Kendall diterjemahkan Thamir Abdul Hafedh Al-Hamdany, B.Sc., M.Sc (2010: 34) mendefinisikan sistem sebegai berikut, Sistem adalah kumpulan dari 
elemen-elemen yang berinteraksi untuk men-capai suatu tujuan tertentu, dan memproses perubahan atau mentranformasikan input menjadi output.

\subsection{Pengertian Informasi}

Menurut McFadden dkk diterjemahkan oleh Agus Mulyanto (2010: 15) Informasi adalah data yang diolah menjadi sebuah bentuk yang berarti bagi penerimanya dan bermanfaat dalam pengambilan keputusan saat ini atau mendatang.

Munurut Barry E, diterjemahkan oleh Agus Mulyanto (2010: 15) informasi merupakan sesuatu yang menunjukan hasil pengolahan data yang diorganisasikan dan berguna kepada orang yang menerimanya.

Menurut Stephen A, Moscove dan Mark G, Simkin dalam bukunya Accounting Information System dan diterjemahkan oleh Agus Mulyanto (2010: 15) mengatakan informasi sebagai kenyataan atau bentuk-bentuk yang berguna yang dapat digunakan untuk pengambilan keputusan bisnis.

\subsection{Pengertian Sistem Informasi}

Menurut Kenneth E. Kendall dan Julie E. Kendall diterjemahkan Thamir Abdul Hafedh Al-Hamdany (2010: 3) Sistem Informasi adalah informasi yang telah terkomputersasi yang bekerja karena adanya interaksi antara manusia dan komputer yang telah diketahui bahwa informasi merupakan hal yang sangat penting bagi manajemen di dalam pengambilan keputusan, dan informasi diperoleh dari sistem informasi (information system) atau disebut juga dengan processing system atau information processing system atau information-genering system, yang didefinisikan sebagai berikut: "Sistem informasi adalah suatu sistem didalam suatu organisasi yang mempertemukan kebutuhan pengolahan transakasi harian, mendukung operasi, bersifat manajerial dan kegiatan strategi dari suatu organisasi dan menyediakan pihak luar tertentu dengan laporan-laporan yang diperlukan."

\subsection{Pengertian Parkir}

Parkir adalah keadaan tidak bergerak suatu kendaraan yang bersifat sementara karena ditinggalkan oleh pengemudinya. Secara hukum dilarang untuk parkir di tengah jalan raya, namun parkir di sisi jalan umumnya diperbolehkan.

Fasilitas parkir dibangun bersama-sama dengan kebanyakan gedung, untuk memfasilitasi kendaraan pemakai gedung. Termasuk dalam pengertian parkir adalah setiap kendaraan yang berhenti pada tempattempat tertentu baik yang dinyatakan dengan rambu lalu lintas ataupun tidak, serta tidak semata-mata untuk kepentingan menaikkan danmenurunkan orangatau barang.

\section{a. Fasilitas Parkir}

Permintaan parkir didistribusikan pada tata guna lahan suatu area. Penetapan pilihan parkir kendaraan yang dibuat dan cara parkir dikelompokkan sebagai berikut:

1) Menurut Penempatannya

a. Parkir di Badan Jalan (On Street Parking)

Tempat yang biasanya digunakkan untuk memarkir kendaraannya ialah ditepi jalan. Tetapi parkir seperti ini mempunyai banyak kerugian seperti arus lalu lintas sepanjang jalan menjadi terhambat dan meningkatnya jumlah kecelakaan.

b. Parkir di Luar Badan Jalan (Off Street Parking)

Di kebanyakan kawasan pusat kota parkir di pinngir jalan sangat dibatasi sehingga diperlukan penyediaan fasilitas parkir di luar daerah jalan. Ada beberapa klasifikasi parkir diluar badan jalan yaitu perlatan parkir permukaan tanah, garasi bertingkat, garasi bawah tanah, gabungan, garasi mekanis dan drive.

Pedoman perancangan untuk parkir diluar badan jalan didasarkan pada ukuran kendaraan, rencana, luas lahan parkir, kapasitas parkir, serta tata letak kendaraan 
untuk memudahkan kendaraan masuk dan keluar parkir.

2) Menurut Statusnya

a. Parkir Umum

Parkir umum adalah perparkiran yang menggunakan tanah, jalan, lapangan yang dimiliki atau dikuasai dan penyelenggaraannya dikelola oleh pemerintah.

b. Parkir Khusus

Parkir khusus adalah parkir yang menggunakan tanah-tanah yang dikuasai oleh pihak ketiga.

c. Parkir Darurat

Parkir darurat adalah perparkiran ditempat umum, baik menggunakan lahan jalan, lapangan milik, dan penguasaannya oleh pemerintah daerah atau swasta karena kegiatan isidentil.

\section{d. Taman Parkir}

Taman parkir adalah suatu area atau bangunan perparkiran yang dilengkapi saran perparkiran yang pengelolanya diselenggarakan oleh pemerintah.

e. Gedung Parkir

Gedung parkir adalah bangunan yang dimanfaatkan untuk tempat parkir kendaraan yang penyelenggaraanya oleh pemerintah daerah atau pihak ketiga yang mendapatkan ijin dari pemerintah daerah.

3) Menurut Jenis Kendaraannya

a. Parkir untuk kendaraan roda dua tidak bermesin (sepeda).

b. Parkir untuk kendaraan roda dua bermesin (sepeda motor).

c. Parkir untuk kendaraab roda tiga, empat atau lebih.

4) Menurut Jenis Tujuan Parkir

a. Parkir penumpang yaitu perkir untuk menaik turunkan penumpang.

b. Parkir barang yaitu parkir untuk bongkar muat barang.

5) Menurut Jenis Pemilikan dan Pengoperasiaanya

a. Parkir milik dan pengoperasiaanya adalah milik swasta. b. Parkir milik pemerintah daerah dan pengelolaanya adalah milik swasta.

c. Parkir milik dan pengoperasiaanya adalah milik pemerintah.

\subsection{Pengertian PowerBuilder}

PowerBuilder merupakan salah satu development tools untuk membuat sebuah aplikasi. Aplikasi yang dibuat dengan menggunakan PowerBuilder lebih dikhusus- kan untuk database, sehingga terkesan klasik dan sangat minim fasilitas - fasilitas visual yang bersifat kosmetik dan tidak berkaitan dengan database.

Menurut tingkatan generasi-nya, Power Builder dikategorikan sebagai bahasa pemrograman tingkat ke 4 (4GL) karena sudah menerapkan bahasa yang dapat dimengerti oleh manusia dan berbasis visual. Jenis aplikasi yang dapat dibuat dengan menggunakan PowerBuilder antara lain Client Server, N-Tier Application \& Web Application.

Dasar pemrograman PowerBuilder adalah Object OrientedProgramming (OOP) yang memiliki karakteristik Inheritance, Encapsulation \& Polymorphism.

Konsep pemrograman PowerBuilder sudah sejak lama menerapkan teknologi framework dengan adanya PowerBuilder Foundation Class(PFC). Teknologi framework ini memungkinkan pembuatan aplikasi dengan lebih cepat dan terstruktur.

Komponen objek-objek Power Builder yaitu:

1) Aplikasi Power Builder

Adalah tempat masuk ke suatu aplikasi yang dibuat secara otomatis oleh Power Builder dan disimpan dalam file pustaka (PBL) seperti window, menu, fuction, dan obyek data window.

\section{2) Window}

Adalah penghubung utama antara pemakai (user) dengan aplikasi Power Builder. Sebuah window terdiri atas: 
a. Properties: digunakan untuk mendefinisikan tampilanwindow.

b. Events: kejadian yang dilaksanakan oleh aksi pemakai (user action).

c. Control: kontrol yang ditempatkan dalam window.

\section{3) Data Window}

Adalah sebuah obyek yang dipakai untuk memanggil dan memenipulasi suatu database relasional atau data lainnya. Data window menyediakan fasilitas-fasilitas sebagai berikut:

a. Presentation Style: digunakan untuk menangani bagaimana sebuah data di presentasikan.

b. Display formats: untuk menentukan bagaimana cara menampilkan sebuah data untuk masing-masing kolom.

c. Edit style: untuk menentukan bagaimana cara memasukkan sebuah data, apakah diketik langsung melalui keyboard atau dengan memilih dengan mouse.

d. Validation: untuk memberikan seperti apa kondisi data yang diterima oleh sebuah kolom.

\section{4) Menu}

Adalah daftar dari perintah-perintah atau pilihan (item menu) yang dapat dipilih pemakai dalam window aktif. Menu-menu yang dibuat dengan Power Builder distandarkan dengan menu sistem operasi Windows.

\section{5) Fungsi}

Power Builder memberikan dua macam fungsi yaitu:

a. Object-level function adalah fungsi yang didefinisikan khusus untuk sebuah window, menu, atau jenis objek lainnya dan hanya digunakan dimana fungsi tersebut didefinisikan.

b. Global function adalah fungsi global yang dapat digunakan oleh semua objek dalam aplikasi.

6) Query

Sebuah query adalah pernyataan SQL yang telah disimpan dengan sebuah nama yang ditentukan dan dapat digunakan secara berulang-ulang sebagai sumber data untuk sebuah Data Window.

\section{7) Structure}

Structure adalah koleksi atau lebih variabel yang saling berhubungan dengan jenis data yang sama atau berbeda dalam sebuah nama. Power Builder memberikan dua macam jenis structure:

a. Object Level Structure: structure lokal yang didefinisikan khusus untuk sebuah window atau menu dan hanya dapat digunakan dimana structure tersebut didefinisikan.

b. Global Structure: structure global yang dapat digunakan dimana saja dalam aplikasi.

8) User Object

Aplikasi pada umumnya sering kali mempunyai gambar. Sebagai contoh umumnya aplikasi mempunyai icon untuk menutup window yaitu close botton, Data window mempunyai ikon baru, ubah, hapus, dan lain sebagainya.

9) Bahasa Pemograman Script

Bahasa pemograman script disebut juga Power Sript adalah bahasa pemograman untuk menyusun program aplikasi pada Power Builder.Power Script berisi sejumlah object oriented yang dapat berkomunikasi antara object dengan penempatan secara langsung object. Atributnya juga mengirim pesan antara object dan atributnya.

\section{0) External Resources}

External Resources adalah bagian dari komponen aplikasi Power Builder yang berupa file gambar dari icon yang diperlukan untuk menjalankan aplikasi. 


\section{1) Project}

Project adalah sebuah objek yang berisi semua informasi yang dibutuhkan untuk membentuk file EXE (executable file).

\section{METODE PENELITIAN}

\subsection{Desain Penelitian}

Metode yang akan digunakan dalam penulisaan skripsi ini adalah penelitian metode deskriptif dengan model studi kasus. Penelitian Deskriptif adalah penelitian yang memberikan gambaran atau mendreskripsikan karakteristik subjek (gambaran suatu subjek atau objek penelitian).

\subsection{Data Dan Sumber Data}

\subsubsection{Jenis Data}

Dalam penelitian ini jenis data yang dikumpulkan dan digunakan adalah data kualitatif sebagai pendukungnya. Data kualitatif adalah data yang tidak berupa angka, untuk membacanya harus dijabarkan secara rinci dan jelas agar bisa menarik simpulan.

\subsubsection{Sumber Data}

Data merupakan sumber informasi yang didapatkan oleh penulis melalui penelitian yang dilakukan. Data yang diperoleh nantinya akan diolah sehingga menjadi informasi baru yang dapat dimanfaatkan oleh pembacanya. Dalam penelitian ini, data diperoleh melalui dua sumber yaitu data primer dan data sekunder. Berikut ini adalah penjabaran sumber data yang digunakan penulis dalam penelitian ini:

\section{a. Data Primer}

Data primer yaitu data yang diperoleh secara langsung melalui informan. Dalam penulisan ini, data primer melalui hasil wawancara dengan manager dan bagian marketing. Dalam penelitian ini, yang diambil adalah subyek yang sedang melakukan kegiatan, karena untuk mengetahui faktorfaktor apa sajakah yang dapat mempengaruhi kinerja karyawan dalam bekerja.

\section{b. Data Sekunder}

Data sekunder yaitu data yang diperoleh penulis untuk mendukung data primer. Data sekunder ini seperti buku-buku mengenai teori-teori pemasaran, penjualan, pembelian, dan buku-buku lain sejenis yang berhubungan dengan pemasaran dan pemesanan di PT. Bersama Kita Besar. Data sekunder juga didapatkan ditempat penulis melakukan penelitian, data yang didapat berupa gambaran umum tempat penelitian, yaitu bagaimana kinerja karyawan apakah sudah memenuhi kebutuhan perusahaan dan gambaran umum dalam menunjang kebutuhan kinerja karyawan agar mencapai tujuan yang diinginkan.

\subsubsection{Obyek Penelitian}

Dalam penyususunan skripsi ini penulis melakukan penelitian dengan mengambil objek penelitian pada PT. KMK Global Sports. Adapun penelitian dilakukan untuk mengetahui kualitas sistem parkir pada PT. KMK Global Sports.

\subsection{Desain Penelitian}

Metode yang akan digunakan dalam penulisaan skripsi ini adalah penelitian metode deskriptif dengan model studi kasus. Penelitian Deskriptif adalah penelitian yang memberikan gambaran atau menderskripsikan karakteristik subjek (gambaran suatu subjek atau objek penelitian).

\subsection{Data Dan Sumber Data}

\subsubsection{Jenis Data}

Dalam penelitian ini jenis data yang dikumpulkan dan digunakan adalah data kualitatif sebagai pendukungnya. Data kualitatif adalah data yang tidak berupa angka, untuk membacanya harus dijabarkan secara rinci dan jelas agar bisa menarik simpulan.

\subsubsection{Sumber Data}

Data merupakan sumber informasi yang didapatkan oleh penulis melalui penelitian 
yang dilakukan. Data yang diperoleh nantinya akan diolah sehingga menjadi informasi baru yang dapat dimanfaatkan oleh pembacanya. Dalam penelitian ini, data diperoleh melalui dua sumber yaitu data primer dan data sekunder. Berikut ini adalah penjabaran sumber data yang digunakan penulis dalam penelitian ini:

\section{a. Data Primer}

Data primer yaitu data yang diperoleh secara langsung melalui informan. Dalam penulisan ini, data primer melalui hasil wawancara dengan manager dan bagian marketing. Dalam penelitian ini, yang diambil adalah subyek yang sedang melakukan kegiatan, karena untuk mengetahui faktorfaktor apa sajakah yang dapat mem-pengaruhi kinerja karyawan dalam bekerja.

\section{b. Data Sekunder}

Data sekunder yaitu data yang diperoleh penulis untuk mendukung data primer. Data sekunder ini seperti buku-buku mengenai teori-teori pemasaran, penjualan, pembelian, dan buku-buku lain sejenis yang berhubungan dengan pemasaran dan pemesanan di PT. Bersama Kita Besar. Data sekunder juga didapatkan ditempat penulis melakukan penelitian, data yang didapat berupa gambaran umum tempat penelitian, yaitu bagaimana kinerja karyawan apakah sudah memenuhi kebutuhan perusahaan dan gambaran umum dalam menunjang kebutuhan kinerja karyawan agar mencapai tujuan yang diinginkan.

\subsubsection{Obyek Penelitian}

Dalam penyususunan skripsi ini penulis melakukan penelitian dengan mengambil objek penelitian pada PT. KMK Global Sports. Adapun penelitian dilakukan untuk mengetahui kualitas sistem parkir pada PT. KMK Global Sports.

\subsection{Metode Pengumpulan Data}

\section{Kuesioner}

Adalah daftar pertanyaan tertulis yang di tunjukan kepada responden untuk mengetahui informasi secara tidak langsung.

2. Observasi

Adalah metode pengumpulan data dengan cara meneliti langsung ke lapangan, baik secara paserta/partisipan ataupun hanya sebagai pengamat untuk mengamati tealita yang ada.

3. Wawancara

Adalah metode pengumpulan data melalui wawancara / secara lisan langsung dengan sumberdatanya, baik melalui tatap muka atau telephone. Jawaban responden direkam dan dirangkum sendiri oleh peneliti.

\subsection{Teknik Analisis Data}

Analisis data adalah proses mencari dan menyusun secara sistematis data yang diperoleh dari hasil wawancara, catatan lapangan dan dokumentasi dengan cara mengkoordinasikan data kedalam kategori, menjabarkan kedalam unit-unit, melakukan sintesa, menyusun kedalam pola, memilih mana yang lebih penting, yang akan dipelajari dan membuat kesimpulan sehingga mudah dipahami oleh diri sendiri dan orang lain.

Analisis data dalam penelitian ini berlangsung melalui tiga tahap model air yaitu reduksi data, penyajian data dan penarikan kesimpulan (verifikasi). Langkah-langkah yang ditempuh adalah sebagai berikut:

1. Tahap Reduksi Data

Reduksi data merupakan proses pemilihan, pemusatan perhatian, pengabstrakan, dan transformasi data yang muncul dari hasil penelitian. Reduksi data terjadi selama pengumpulan data berlangsung dimana sudah tampak pada saat peneliti memutuskan kerangka konseptual, wilayah penelitian, permasalahan penelitian, pendekatan penelitian dan metode pengumpulan data. Dengan reduksi data menghasilkan informasi yang relevan dan tidak relevan dan dapat digunakan untuk menarik kesimpulan. 


\section{Penyajian Data}

Penyajian data merupakan sekumpulan informasi tersusun yang memberi kemungkinan adanya penarikan kesimpulan dan pengambilan tindakan menurut Matthew dan Michael dikutip oleh Hamid Patilima (2011). Penyajian sering menggunakan bentuk teks naratif dimana teks tersebut tidak tersusun dengan baik dan sangat berlebihan. Kondisi tersebut seringkali terjadi pada peneliti dalam melakukan kesalahan atau gegabah dalam mengambil kesimpulan. Oleh karena itu, peneliti harus menampilkan data yang dianalisa untuk melihat perbedaan dan persamaan informasi subjek.

3. Penarikan Kesimpulan

Penarikan kesimpulan merupakan suatu proses yang bermula pada pengumpulan data, pengertian, pola, alur sebab-akibat, dan proposi. Kesimpulan akhir berdasarkan pada kumpulan catatan penelitian, penyimpanan, metode pencarian ulang, dan kecakapan peneliti. Kesimpulan dapat ditarik dari data yang diambil dari penelitian yang kemudian dapat dibandingkan hasilnya.

\subsection{Metode Perancangan Sistem Waterfall}

Menurut Sommerville (2011,30-31) waterfall adalah tahapan utama yang langsung mencerminkan dasar pembangunan kegiatan, berikut ini adalah tahapannya:

a. Requirements analysis and definition

Merupakan bagian dari system yang terbesar dalam pengerjaan suatu proyek, dimulai dengan menetapkan kebutuhan dari semua elemen yang diperlukan system.

b. System and software design

Tahapan penerjemaah dari data yang analisis ke dalam sebuah representasi perangkat lunak yang diperkirakan demi kualitas sebelum dimulai pemunculan kode.

c. Implementation and unit testing

Desain program diterjemahkan dalam kode-kode dengan menggunakan bahasa pemrograman yang sudah ditentukan.

d. Integration and system testing
Proses pengujian dilakukan pada logika internal untuk memastikan semua pernyataan sudah diuji.

e. Operating and maintenance

Mengoprasikan dan melakukan pemeliharaan, seperti penyesuaian atau perubahan unutk adaptasi dengan situasi yang sebenarnya.

Kelebihan dari model ini adalah selain karena pengaplikasian menggunakan model ini mudah, semua kebutuhan sistem didefinisikan secara utuh, eksplisit, dan benar diawal proyek, maka software engineering dapat berjalan dengan baik dan tanpa masalah meskipun seringkali kebutuhan sistem tidak dapat didefinisikan secara se-eksplisit yang diinginkan.

Kekurangan utama dari model ini adalah kesulitan dalam mengakomodasi perubahan setelah proses dijalani, fase sebelumnya harus lengkap dan selesai sebelum mengerjakan fase berikutnya.

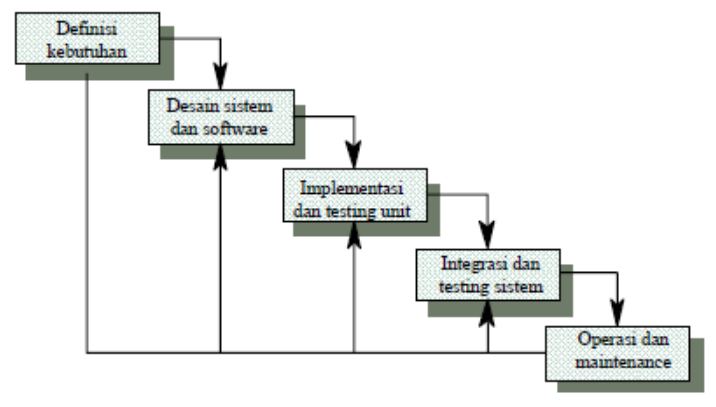

Gambar 3.1 Metode Waterfall

Sumber Data: Sommerville (2011,30-31)

\section{ANALISIS DAN PEMBAHASAN}

\subsection{Sistem Yang Berjalan}

Proses sistem parkir yang sedang berjalan pada PT. KMK Global Sports yaitu:

\section{a. Sistem yang Berjalan}

1) Ketika pengendara masuk ke area parkir, pengendara bisa langsung parkir di area dasar.

2) Apabila area parkir dasar penuh petugas parkir mengarahkan parkir ke lantai dua, dan apabila lan-tai 
dua penuh petugas mengarahkan parkir ke lantai tiga.

3) Ketika pengendara akan keluar area parkir, pengendara bisa lang-sung keluar tanpa ada pemeriksaan kepemilikan kendaraan oleh petugas parkir.

b. Use Case Diagram Sistem yang Berjalan

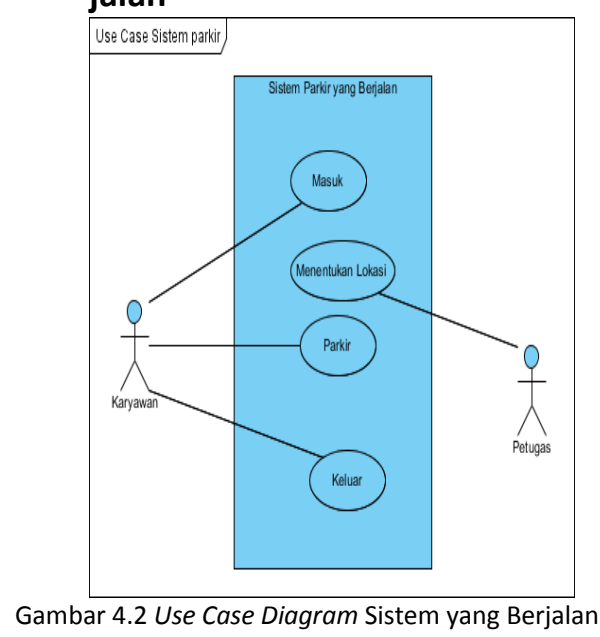

c. Activity Diagram Sistem yang Berjalan

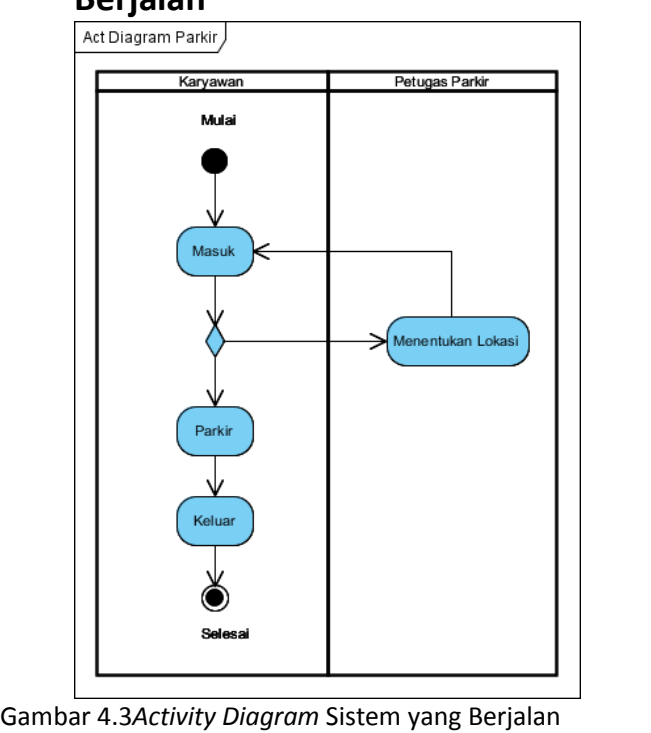

\section{d. Masalah yang Terjadi}

Masalah yang terjadi pada sistem informasi yang berjalan saat ini sebagai berikut:
1) Tidak tersedia informasi pada sistem parkir di PT. KMK Global Sports sehingga terjadi penumpukan kendaraan di are tertentu.

2) Pembagian area parkir yang tidak maksimal, berdesakan sehingga menyebabkan kerusakan kendaraan.

3) Terjadi tindakan yang tidak diinginkan seperti tindakan kriminalitas, pencurian dan lain-lain.

Guna menangani permasalahan diatas penulis merancang sistem informasi Parkir Kendaraan yang dapat memberikan akses kemudahan dalam penentuan area parkir pada PT. KMK Global Sports.

\section{e. Alternatif Pemecahan Masalah}

Berikut beberapa alternatif dalam pemecahan masalah:

1) Membagi area parkir menjadi beberapa blok, per blok diisi oleh kendaraan yang jumlahnya disesuaikan dengan kapasitas parkir.

2) Memberi nama lokasi yang diisi oleh kendaraan.

3) Meminta data karyawan yang membawa kendaraan kepada tiap departemen untuk mengetahui berapa jumlah karyawan yang mengunakan kendaraan bermotor.

\subsection{Rancangan Sistem Usulan}

Guna membantu dalam pemecahan masalah yang terjadi, penulis mencoba merancang sistem yang diusulkan sebagai berikut:

\subsubsection{Use Case Diagram}

Use Case mendeskripsikan sistem, lingkungan sistem, serta hubungan antara sistem dengan yang lainnya. 


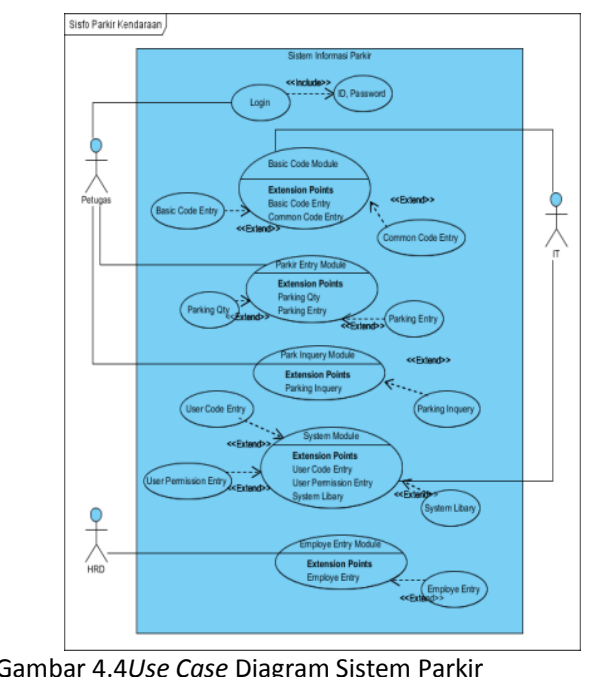

\section{Keterangan:}

\section{a. Definisi Aktor}

Berikut merupakan deskripsi pendefinisian aktor pada Sistem Informasi Parkir Kendaraan:

Tabel 4.1 Definisi Aktor

\begin{tabular}{|l|l|l|}
\hline No & Aktor & \multicolumn{1}{c|}{ Deskripsi } \\
\hline 1 & Petugas & $\begin{array}{l}\text { Orang yang memiliki hak } \\
\text { akses terhadap sistem } \\
\text { untuk melakukan operasi } \\
\text { pengolahan data. }\end{array}$ \\
\hline 2 & IT & $\begin{array}{l}\text { Bagian yang berwenang } \\
\text { untuk merubah aplikasi. }\end{array}$ \\
\hline 3 & HRD & $\begin{array}{l}\text { Bagian yang berwenang } \\
\text { menambah data } \\
\text { karyawan yang menjadi } \\
\text { member. }\end{array}$ \\
\hline
\end{tabular}

\section{b. Definisi Use Case}

Berikut merupakan deskripsi pendefinisian Use Case pada Sistem Informasi Parkir Kendaraan:

Tabel 4.2 Definisi Use Case

\begin{tabular}{|l|l|l|}
\hline No & \multicolumn{1}{|c|}{ Use Case } & \multicolumn{1}{c|}{ Deskripsi } \\
\hline 1 & Login & $\begin{array}{l}\text { Merupakan proses untuk } \\
\text { masuk kedalam aplikasi yang } \\
\text { dilakukan oleh petugas. }\end{array}$ \\
\hline 2 & Basic CodeModule & $\begin{array}{l}\text { Merupakan kegiatan untuk } \\
\text { menambah modul, merubah } \\
\text { modul dan menambah area } \\
\text { parkir }\end{array}$ \\
\hline 3 & $\begin{array}{l}\text { Parking Entry } \\
\text { Module }\end{array}$ & $\begin{array}{l}\text { Merupakan kegiatan untuk } \\
\text { menambah kapasiti area } \\
\text { parkir dan proses in/out } \\
\text { kendaraan }\end{array}$ \\
\hline 4 & $\begin{array}{l}\text { Parking Inquery } \\
\text { Module }\end{array}$ & $\begin{array}{l}\text { Merupakan kegiatan untuk } \\
\text { melihat data keluar masuk } \\
\text { kendaraan }\end{array}$ \\
\hline 5 & System Module & $\begin{array}{l}\text { Merupakan kegiatan untuk } \\
\text { menambah hak akses siapa } \\
\text { saja yang bisa menggunakan } \\
\text { aplikasi ini }\end{array}$ \\
\hline 6 & $\begin{array}{l}\text { Merupakan kegiatan } \\
\text { menambah data karyawan } \\
\text { yang menjadi member }\end{array}$ \\
\hline
\end{tabular}

c. Skenario Use Case

1) Nama Use Case: Login

Aktor: Petugas Parkir

Deskription: Kegiatan dimana petugas memasukkan id petugas.

Precondition: Petugas sudah mempunyai id petugas.

Petugas berada pada menu Login.

Postcondition: Login Berhasil.

Tabel 4.3 Keterangan Use Case Diagram Login

\begin{tabular}{|l|l|}
\hline \multicolumn{2}{|c|}{ Alur Dasar } \\
\hline $\begin{array}{l}\text { 1. Memastor } \\
\text { dan password_petugas }\end{array}$ & \multicolumn{1}{|c|}{ Sistem } \\
\hline 2. Menekan tombol Login & $\begin{array}{l}\text { 3. Melakukan validasi } \\
\text { id_petugas yang } \\
\text { dimasukan }\end{array}$ \\
\hline & $\begin{array}{l}\text { 4. Jika id petugas valid maka } \\
\text { login berhasil dan masuk } \\
\text { ke menu utama }\end{array}$ \\
\hline $\begin{array}{l}\text { Alur Alternatif 1 } \\
\text { a. Jika id yang dimasukan tidak valid maka akan muncul pesan } \\
\text { "Checking to Password". }\end{array}$ \\
\hline
\end{tabular}

2) Nama Use Case: Basic Code Module Deskription: Kegiatan dimana bagian IT menambahkan modul pada halaman window.

Precondition: Bagian IT mendapatkan tugas untuk

menambah modul. Bagian IT berada

dihalaman window.

Postcondition: Modul tersimpan.

Tabel 4.4 Keterangan Use Case Diagram Basic Code Module

\begin{tabular}{|c|c|}
\hline \multicolumn{2}{|c|}{ Alur Dasar } \\
\hline Aktor & Sistem \\
\hline \multicolumn{2}{|l|}{$\begin{array}{l}\text { 1. Masukan id code, short } \\
\text { name dan full name }\end{array}$} \\
\hline \multicolumn{2}{|l|}{ 2. Pilih ikon save } \\
\hline & 3. menyimpan data \\
\hline & $\begin{array}{l}\text { 4. Jika data tersimpan dalam } \\
\text { database akan } \\
\text { menampilkan pesan } \\
\text { "Data Save Success" }\end{array}$ \\
\hline \multicolumn{2}{|c|}{$\begin{array}{l}\text { Alur Alternatif } 2 \\
\text { a. Jika nama id code dan short name yang dimasukan sama } \\
\text { dengan nama sébelumnyà maká dăta tidák ákán térsimpan } \\
\text { dalam database dan menampilkan pesan "Data Save } \\
\text { Failure' }\end{array}$} \\
\hline
\end{tabular}


3). Nama Use Case: Parking Entry Module Aktor: Petugas Parkir

Description: Kegiatan dimana petugas parkir

melakukan proses input data kendaraan

masuk/ keluar.

Precondition: Petugas sudah mempunyai id petugas.

Petugas berada dimenu park in/out.

Postcondition: Proses parkirln / Out

Tabel 4.5 Keterangan Use Case Diagram Parking Entry Module
\begin{tabular}{|l|l|}
\hline \multicolumn{2}{|c|}{ Alur Dasar } \\
\hline \multicolumn{1}{|c|}{ Aktor } & \multicolumn{1}{|c|}{ Sistem } \\
\hline $\begin{array}{l}\text { 1. Pilih status parkir } \\
\text { milih area parkir yang } \\
\text { masong }\end{array}$ & \\
\hline 3. Masukan id karyawan & $\begin{array}{l}\text { 4. Jika id karyawan sudah } \\
\text { terdaftar menjadi member } \\
\text { maka akan muncul Nik, } \\
\text { Nama dan Plat No } \\
\text { Karyawan }\end{array}$ \\
\hline 9. Jalur Alternatif 3 & $\begin{array}{l}\text { a. Jika id karyawan yang di masukan belum terdaftar sebagi } \\
\text { member maka akan muncul pesan "ID Not found please check } \\
\text { employe entry" }\end{array}$ \\
\hline
\end{tabular}

4) Nama Use Case: Parking Inquery Module

Aktor: Petugas Parkir

Description: Kegiatan dimana petugas melihat data keluar masuknya kendaraan.

Precondition: Petugas mempunyai id_petugas.

Petugas berada di menu park inquery module.

Postcondition: Petugas melihat data in/outkaryawan.

Tabel 4.6 Keterangan Use Case Parking Inquery Module

\begin{tabular}{|ll|l|}
\hline \multicolumn{2}{|c|}{ Alur Dasar } \\
\hline \multicolumn{1}{|c|}{ Aktor } & \\
\hline 1. $\begin{array}{l}\text { Masukkan id } \\
\text { karyawan }\end{array}$ & \\
\hline 2. Pilih ikon view & $\begin{array}{r}\text { 3. Maka akan muncul data } \\
\text { keluar masuk kendaraan }\end{array}$ \\
\hline & & \\
\hline
\end{tabular}

5). Nama Use Case: System module Aktor: Bagian IT

Description: Kegiatan dimana bagian IT menambah

hak akses siapa saja yang berhak menggunakan sistem ini.

Precondition: Bagian IT mendapatkan tugas untuk

menambah hak akses siapa saja yang berhak mengunakan sistem ini. Bagian IT berada di menu System Module.

Postcondition: Menambah hak akses penggunasistem.

Tabel 4.7 Keterangan Use Case System Module

\begin{tabular}{|l|l|}
\hline \multicolumn{2}{|c|}{ Alur Dasar } \\
\hline $\begin{array}{l}\text { Aktor } \\
\text { 1. Masukan user code, } \\
\text { password dan user } \\
\text { name }\end{array}$ & \\
\hline 2. Pilih ikon Save & Sistem \\
\hline $\begin{array}{l}\text { 4. Pilih User Permission } \\
\text { Entry }\end{array}$ & 3. Menyimpan Data \\
\hline $\begin{array}{l}\text { 5. Pilih user id, klik otoritas } \\
\text { yang diinginkan }\end{array}$ & \\
\hline 6. Pilih ikon Save & 7. Menyimpan data \\
\hline
\end{tabular}

6). Nama Use Case: Employe Entry Module

Aktor : HRD

Deskription: Bagian HRD mendapatkan tugas siapa

saja karyawan yang masuk menjadi member.

Precondition: Bagian HRD memiliki id user. Bagian

HRD berada di menuEmploye Entry Module

Postcondition: Menambahkan member karyawan.

Tabel 4.8 Keterangan Use Case Employe Entry Module

\begin{tabular}{|l|l|}
\hline \multicolumn{2}{|c|}{ Alur Dasar } \\
\hline $\begin{array}{l}\text { 1. Masukan Nik, Nama dan Plat } \\
\text { Nomor }\end{array}$ & \\
\hline 2. Pilih ikon Save & Sistem \\
\hline & 3. Menyimpan Data \\
\hline & $\begin{array}{l}\text { 4. Jika data sudah tersimpan } \\
\text { dalam database akan } \\
\text { menampilkan pesan "Data } \\
\text { Save Success" }\end{array}$ \\
\hline $\begin{array}{l}\text { 5. Jalur Alternatif 4 } \\
\text { a. Jika Data yang di input sudah di input sebelumnya maka data tidak } \\
\text { akan tersimpan dan akan menampilkan pesan "Data Alredy Exist!" }\end{array}$ \\
\hline
\end{tabular}




\subsubsection{Activity Diagram}

a. Activity Diagram Login

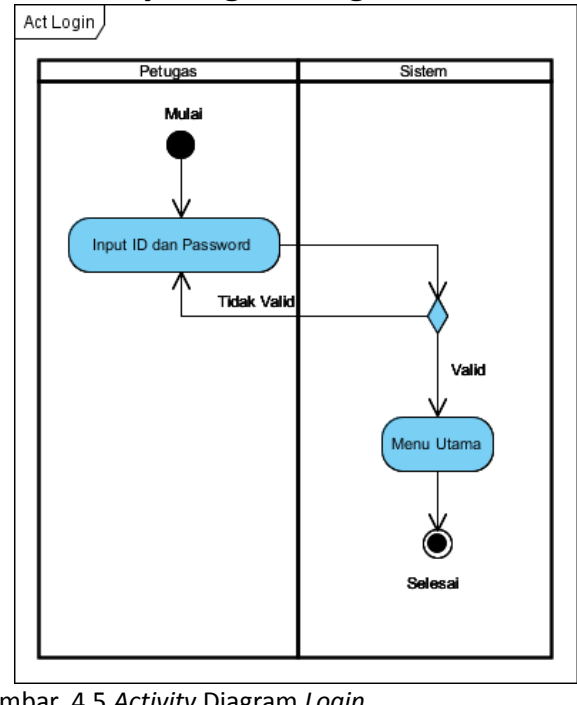

Gambar 4.5 Activity Diagram Login

b. Activity Diagram Basic Code Module Act Tambah Module

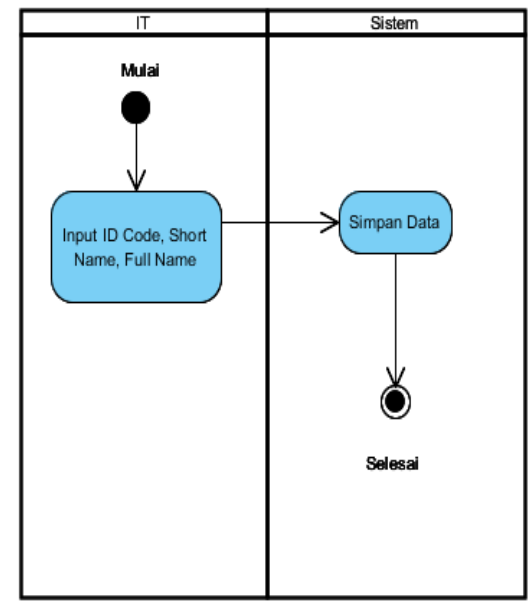

Gambar 4.6 Activity DiagramBasic Code Module c. Activity DiagramPark Entry Module Act park in

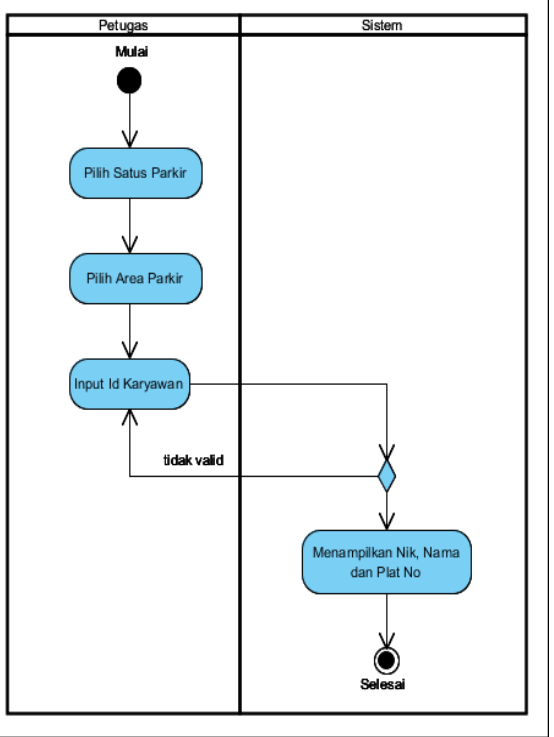

Gambar 4.7 Activity Diagram Parking Entry Module

d. Activity Diagram Park Inquery module

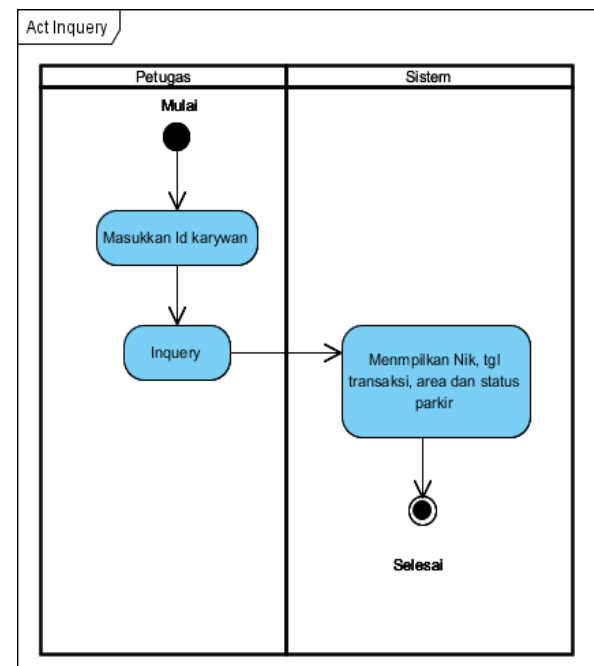

Gambar 4.8 Activity Diagram Park Inquery Module 


\section{e. Activity DiagramSystem Module}

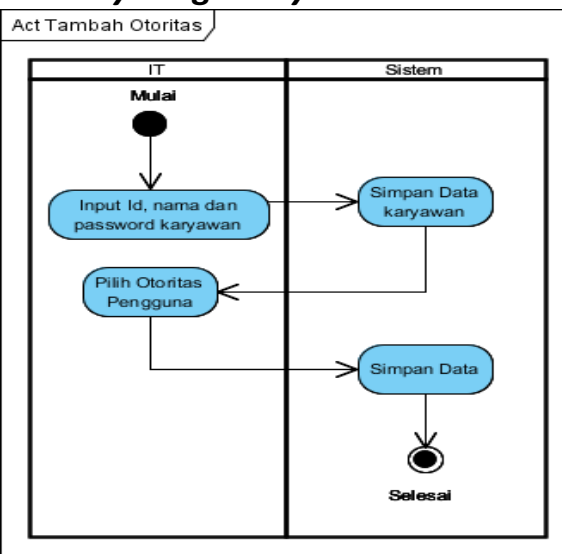

Gambar 4.9 Activity Diagram System Module

f. Activity Diagram Employe Entry Moduele

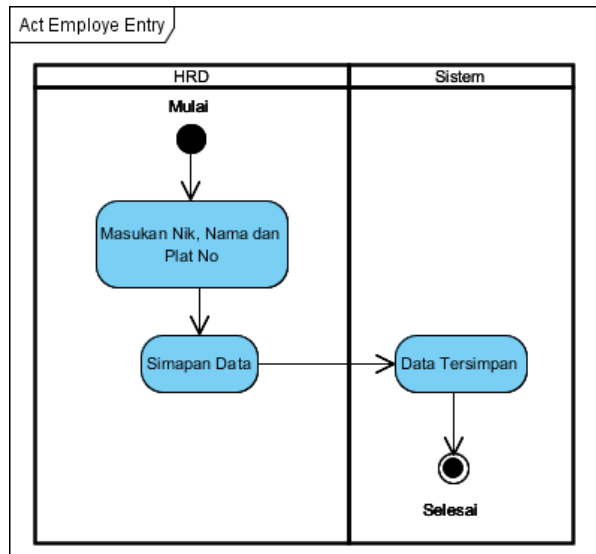

Gambar 4.10 Activity Diagram Employe Enty Module

\subsubsection{Sequence Diagram}

a. Sequence Diagram Login

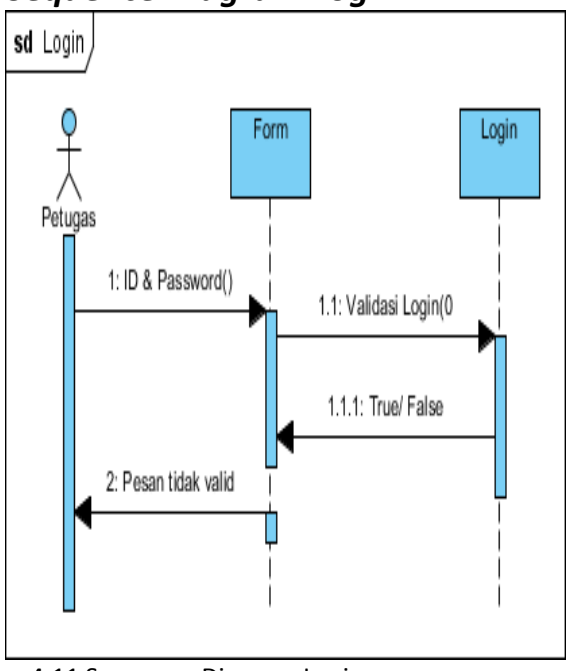

Gambar 4.11 Sequence Diagram Login b. Sequence Diagram Basic Code Module

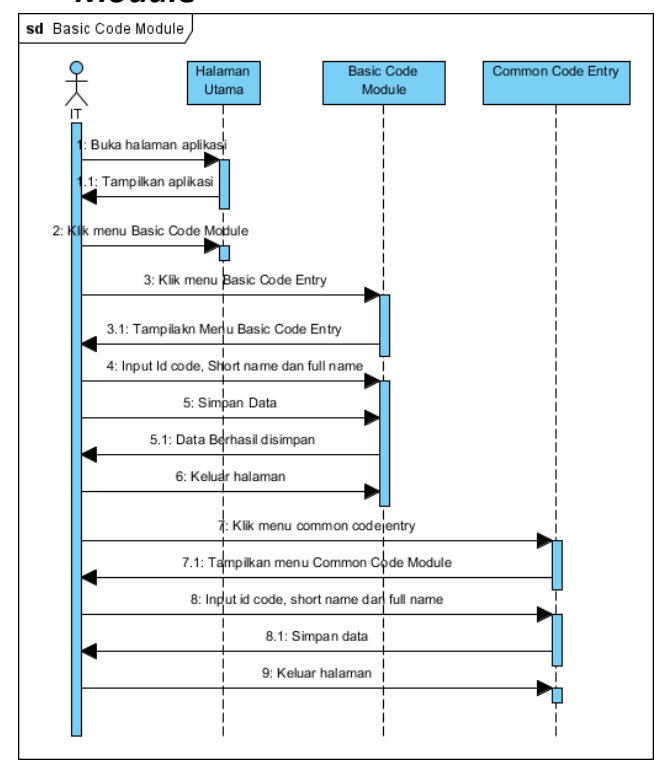

Gambar 4.12 Sequence Diagram Basic Code Module

\section{c. Sequence Diagram Park Entry Module}

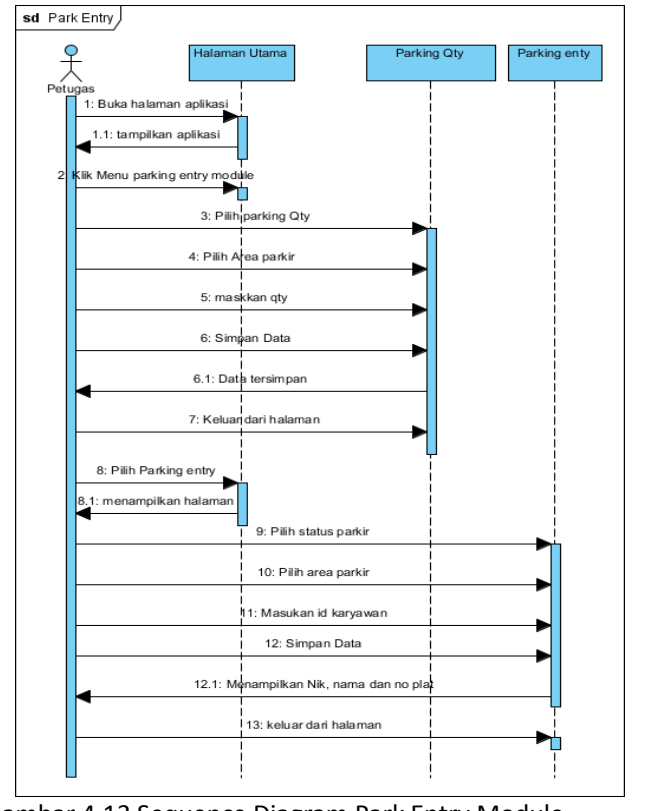

Gambar 4.13 Sequence Diagram Park Entry Module 


\section{d. Sequence Diagram Parking Inquery}

\section{Module}

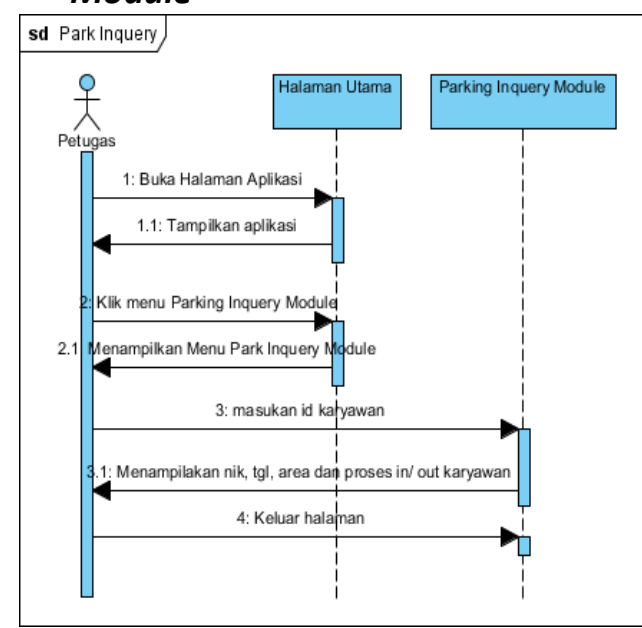

Gambar 4.14 Sequence Diagram Park Inquery Module

e. Sequence Diagram System Module sd System Module

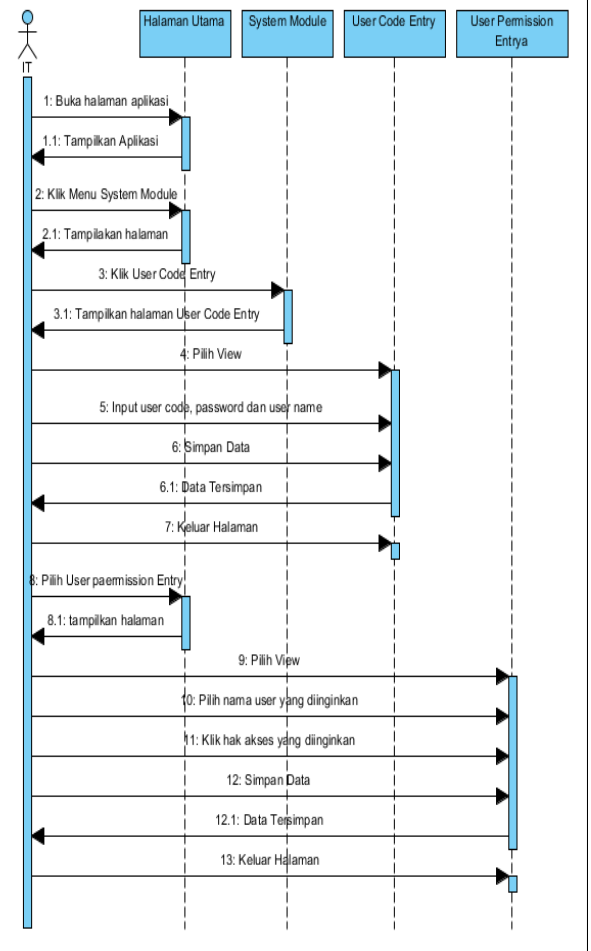

Gambar 4.15 Sequence Diagram System Module

\section{f. Sequence Diagram Employe Entry} Module

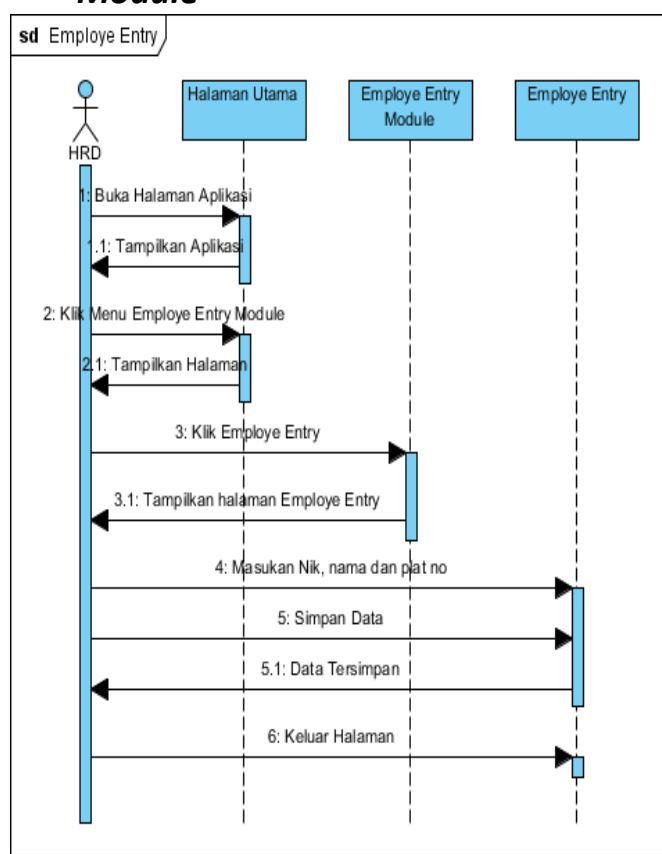

Gambar 4.16 Sequence Diagram Employe Entry Module

\subsubsection{Class Diagram}

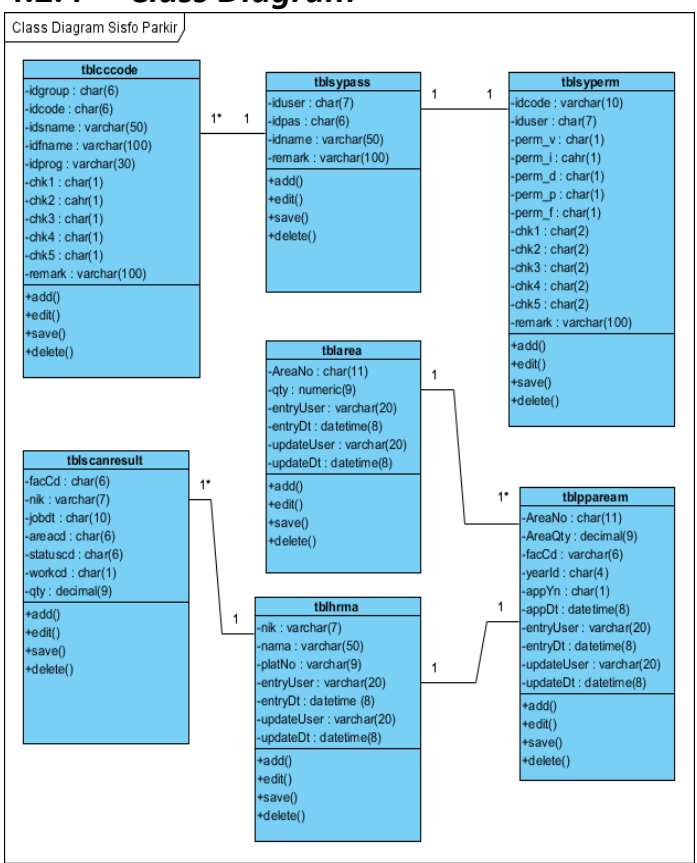

Gambar 4.17 Class Diagram Sistem Parkir 
4.2.5 Rancangan Sistem

a. Rancangan Menu Login

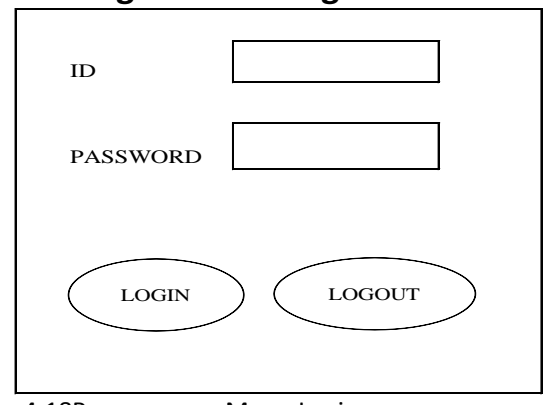

Gambar 4.18Perancangan Menu Login

b. Rancangan Parking Qty

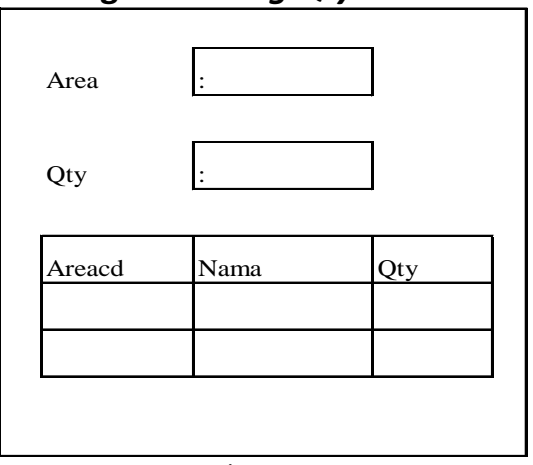

Gambar 4.19 RancanganParking Qty

\section{c. Rancangan Parking Entry}

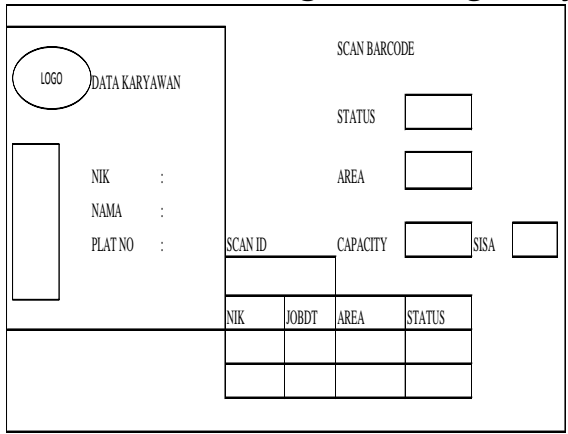

Gambar 4.20 Rancangan Parking Entry

d. Rancangan Employe Entry

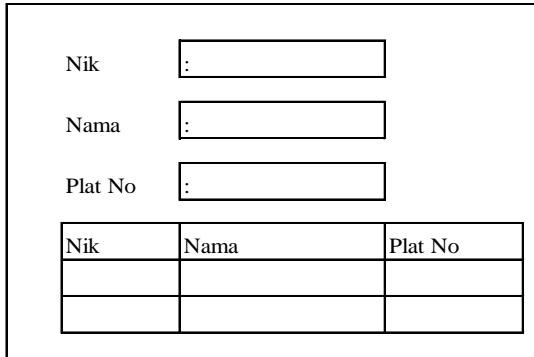

Gambar 4.21 Rancangan Employe Entry
4.2.6 Implementasi/ Tampilan Sis-tem

a. Menu Login

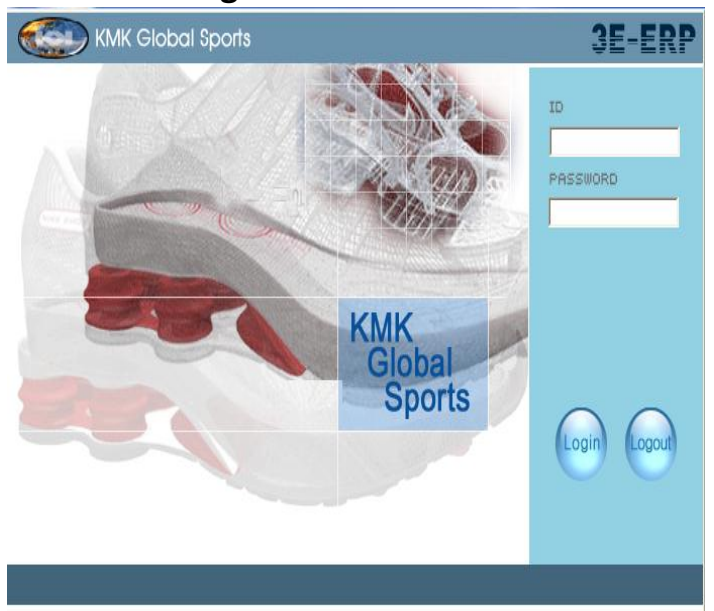

Gambar 4.22 Menu Login

b. Menu Utama

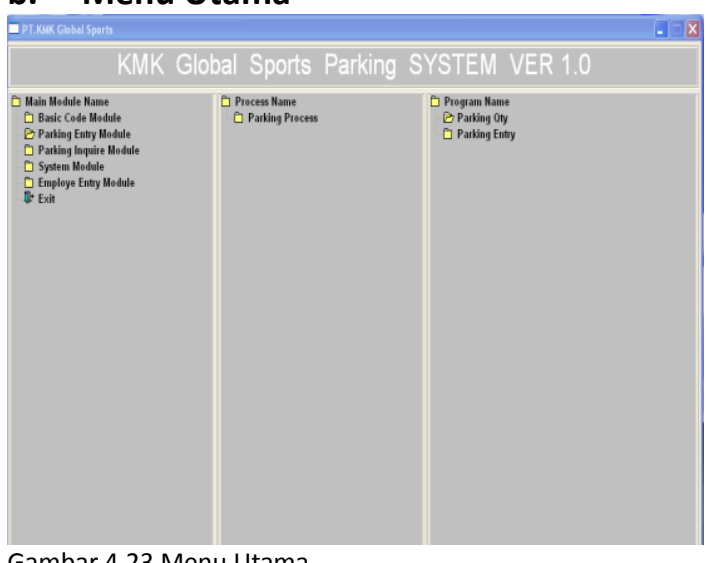

Gambar 4.23 Menu Utama

\section{c. Menu Basic Code Entry}

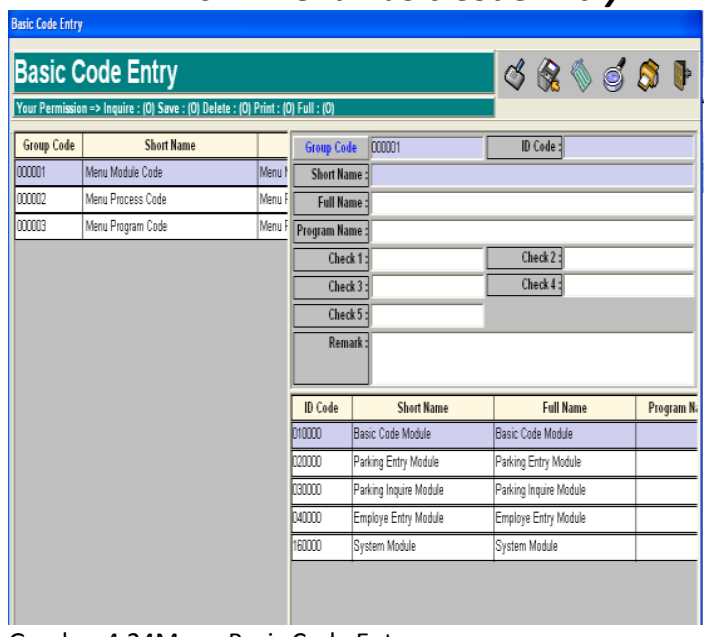

Gambar 4.24Menu Basic Code Entry 


\section{d. Menu Common Code Entry}

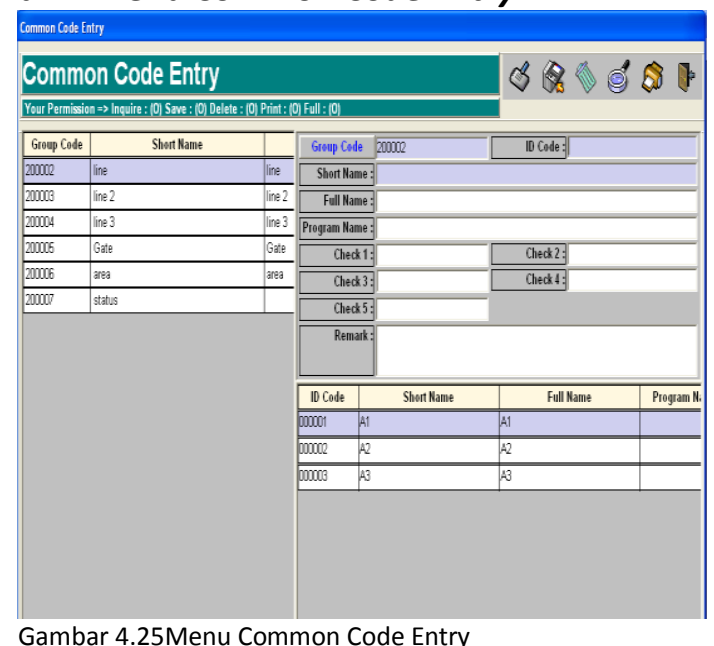

\section{e. Menu Parking Qty}

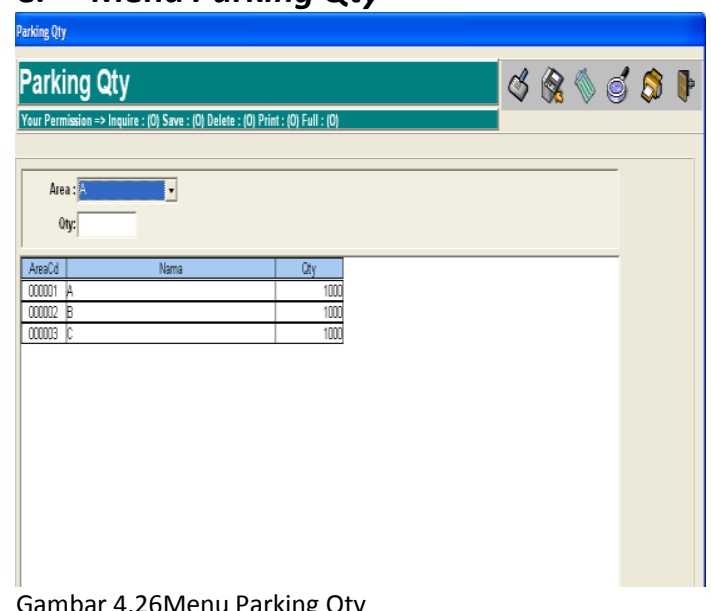

\section{f. Menu Parking Entry}

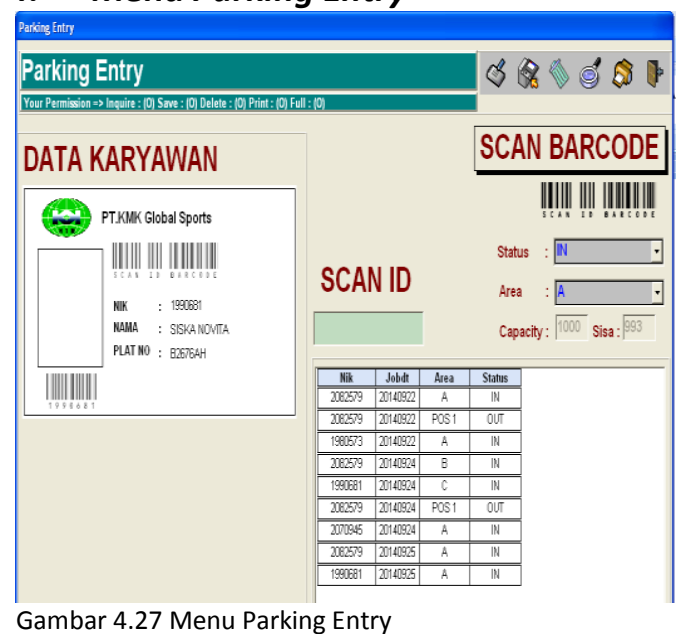

\section{g. Menu Parking Inquire}

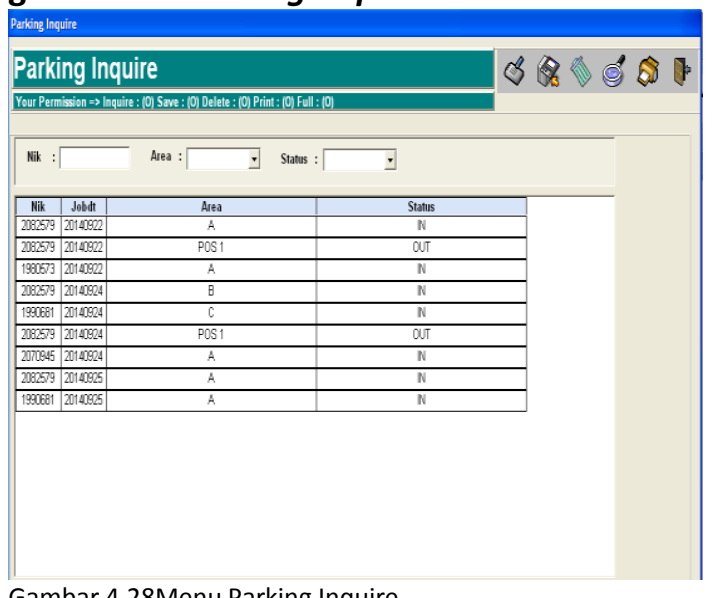

Gambar 4.28Menu Parking Inquire

\section{h. Menu User Code Entry}

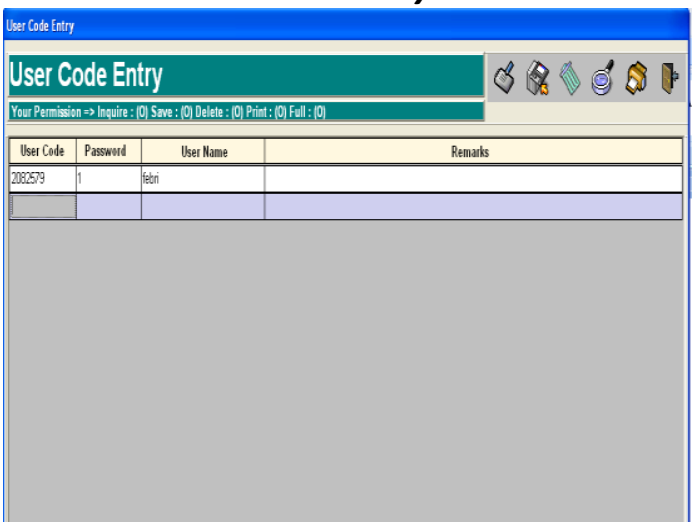

Gambar 4.29Menu User Code Entry

\section{i. MenuUser Permission Entry}

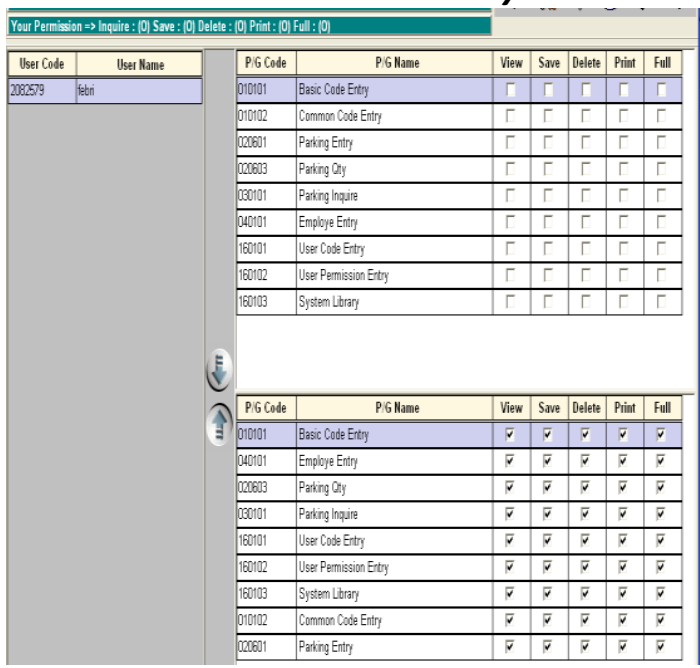

Gambar 4.30 Menu User Permission Entry 
j. Menu Employe Entry

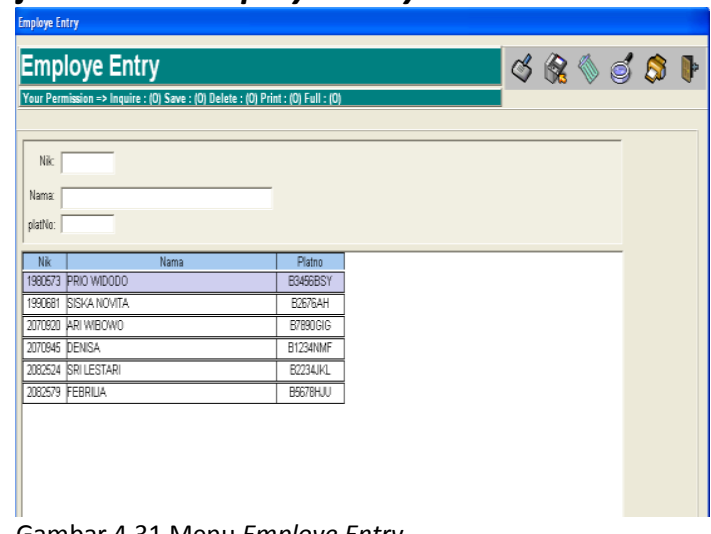

Gambar 4.31 Menu Employe Entry

\section{KESIMPULAN}

Berdasarkan pembahasan yang sudah ada pada bab-bab sebelumnya, maka dapat disimpulkan bahwa:

1. Sistem parkir PT. KMK Global Sports menggunakan sistem manual dan dapat dikatakan belum efektif, dikarenakan membutuhkan waktu yang lama dalam mengecek keleng-kapan surat-surat kendaraan.

2. Sistem informasi yang digunakan menggunakan aplikasi power builder serta SQL Server sebagai databasenya.

3. Penggunaan sistem informasi dapat memberikan data-data kendaraan yang pernah parkir di perusahaan, sedangkan cara manual tidak dapat melakukannya.

\section{REFERENS}

Al-Jufri. (2011). Sistem Informasi Manajemen Pendidikan. Jakarta: Grafika.

A.S, Rosa dan Shalahudin. M. (2013). Rakayasa Perangkat Lunak. Bandung: Informatika Bandung.

Al-Fatta, Hanif (2011). Analisis dan Perancangan Sistem Informasi untuk Ke- unggulan Bersaing Perusahaan dan Organisasi Modern. Yogyakarta: Andi Offset.

Jogianto, H. M. (2010). Analisa Dan Desain Informasi. Yogyakarta: Andi.

McLeod R. jr. dan Schell, GP. 2010. Sistem Informasi Manajemen. Jakarta: Salemba Empat.

Pudjo Widodo, Prabowo dan Herlawati. (2011). Menggunakan UML. Bandung: Informatika.

Sutabri, Tata. (2012). Analisa Sistem Informasi. Yogyakarta: Andi.

Sucipto (2011). Konsep dan Teknik Pengembangan Sistem Berbasis Teknologi Informasi. Banten: Dinas Pendidikan Propinsi Banten.

Tantra, Rudy. (2012). Manajemen Proyek Sistem Informasi. Yogyakarta: Andi.

Talib, Haer. (2011). Panduan Praktis Menguasai Komputer. Jakarta: Elex Media Komputindo. 


\title{
ANALISA DAYA POTONG PADA MESIN POTONG GRAPHITE PACKING
}

\author{
Oleh: \\ Joko Hardono
}

\begin{abstract}
ABSTRAK
Tujuan dari suatu proses rekayasa engineering antara lain untuk membantu perkerjaan manusia sehingga akan meningkatkan produktifitas, effisien dan kualitas produk yang lebih baik dan konsisten. Mesin pemotong Graphite packing merupakan suatu hasil inovasi yang dirancang untuk melakukan pemotongan. Dengan mesin ini pemotongan sheet packing yang sebelumnya dikerjakan secara manual dengan pemahatan/pemboran dan pengguntingan digantikan secara otomatis oleh mesin. Agar tujuan inovasi ini tercapai yaitu produktivitas dan effisiensi maka konstruksi mesin harus dirancang sedemikian rupa sehingga mudah dan ergonomis dalam pengoperasiannya. Disamping itu juga perlu dihitung kebutuhan daya yang diperlukan sehingga bisa ditentukan daya motor penggerak yang sesuai.

Mesin potong Graphite packing dirancang dengan motor listrik sebagai penggerak utama. V-belt, pulley dan roda gigi digunakan untuk meneruskan putaran motor ke pisau pemotong. Putaran motor dari 1400 rpm diteruskan ke pulley input reduser menjadi $280 \mathrm{rpm}$. Oleh reduser putran ini direduksi menjadi $28 \mathrm{rpm}$. Dari pulley output reduser putaran diteruskan ke pulley penggerak poros cutter menjadi 10 rpm. Putaran inilah yang akan menggerakkan cutter. Daya pemotongan merupakan penjumlahan dari daya pemotongan langsung Graphite oleh cutter ditambah dengan daya yang diperlukan untuk memutar komponen-komponen yang bergerak.

Dengan menggunakan perumusan gaya dan daya potong serta daya untuk menggerakkan komponen diperoleh bhawa untuk melakukan pemotongan Graphite dengan tebal maksimum $3 \mathrm{~mm}$ diperlukan daya pemotongan sebesar $87,4 \mathrm{Watt}$. Jika digunakan motor dengan effisiensi $90 \%$ maka daya motor yang diperlukan sebesar 97,11 Watt atau setara dengan 0,13 HP.
\end{abstract}

Kata Kunci : Mesin, potong, daya, motor.

\section{PENDAHULUAN}

Mekanisasi akan membantu suatu proses pekerjaan menjadi lebih produktif dan dihasilkan produk dengan kualitas yang lebih baik dibandingkan dengan pekerjaan yang dilakukan secara manual. Kerana kinerja mesin memiliki kesetabilan yang lebih baik dibanding dengan kinerja manusia. Mesin pemotong Graphite packing merupakan suatu hasil inovasi yangg dirancang untuk melakukan pemotongan
Dalam jurnal ini penulis akan membahas tentang analisa daya potong pada mesin Graphite packing. Packing yang dihasilkan berbentuk lingkaran berlubang. Sebelumnya pemotongan Graphite/packing ini dilakukan secara manual dengan pemahatan, pemboran dan pengguntingan. Tentunya dengan proses ini diasamping akan memakan waktl yang lama juga hasilnya akan kurang presisi. Adapun keunggulan dari mesin ini adalah sebagai berikut: 
a. Metode pengoperasian mesin yang sederhana.

b. Spesifikasi benda kerja dapat disesuaikan dengan kebutuhan.

c. Nilai ekonomis yang tinggi dibandingkan dengan alat potong yang lain seperti blanking tool, pemahatan, pengeboran dan pengguntingan.

Pembahasan hanya terbatas pada :

a. Perancangan konstruksi mesin pemotong

b. Analisa mengenai desain mesin konstruksi mesin pemotong tidak dibahas

c. Analisa daya motor yang diperlukan untuk melakukan pemotongan Graphite packing

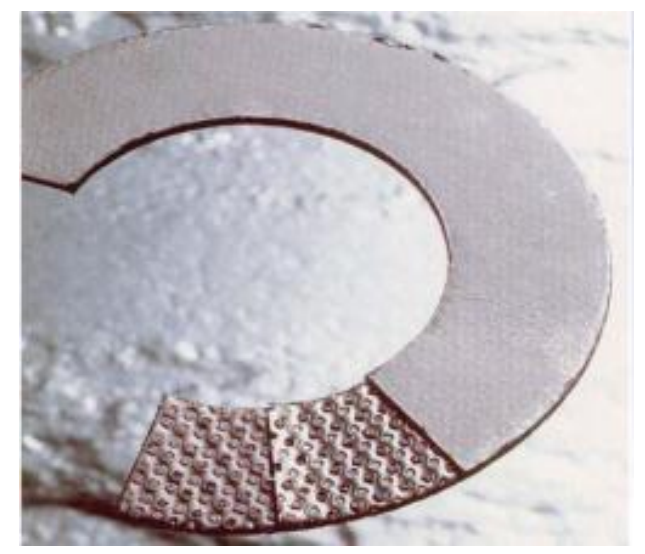

Gambar 1. Graphite Packing

\section{TUJUAN PENULISAN}

Tujuan penulisan jurnal IImiah ini adalah:

a. Sebagai acuan dalam memlih motor penggerak mesin

b. Memberikan masukan pemikiran yang berupa perancangan alat potong packing yang mampu melakukan pemotongan packing Graphite sehingga lebih produktif dan effisien.

c. Merangsang para designer untuk melanjutkan dan melengkapi kekurangan dalam jurnal miah ini.

\section{TINJAUAN PUSTAKA}

3.1 Gaya Pemotongan

Secara garis besar ada dua macam gaya pemotongan, yaitu :

\section{a. Potong tekan (Punching)}

Besar gaya potong tekan dirumuskan dengan persamaan :

$F=\frac{L \cdot t \cdot S_{s}}{2000}$

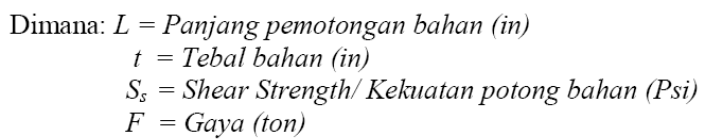

\section{b. Potong Geser (Shearing)}

Besar gaya potong geser dirumuskan dengan persamaan :

$$
F_{s}=K \cdot F \quad \text { dengan } K=\frac{t . P}{S}
$$

Dimana:

$$
\begin{aligned}
& K=\text { Konstanta } \\
& P=\text { Penetrasi }(\%) \\
& S=\text { Kedalaman shearing dari cutter }(\mathrm{mm}) \\
& F_{s}=\text { Gaya shearing }\left(\mathrm{N} / \mathrm{mm}^{2}\right)
\end{aligned}
$$

Dalam proses pogtong geser agar benda kerja tidak terjepit perlu diberikan kelonggaran pemotongan (Us), yaitu jarak kesejajaran antara pisau atas dengan pisau bawah. Kelonggaran Pemotongan Dirumuskan dengan:

$$
\mathrm{U}_{\mathrm{S}=\mathrm{c} . \mathrm{s}} \sqrt{\tau_{g}}
$$

Dimana:

$$
\begin{aligned}
& U_{s}=\text { Kelonggaran Potong }(\mathrm{mm}) \\
& s=\text { Tebal material yang dipotong }(\mathrm{mm}) \\
& c=\text { Working faktor }(\text { diambil } 0,01) \\
& \tau_{g}=\text { Tegangan Geser }\left(\mathrm{N} / \mathrm{mm}^{2}\right)
\end{aligned}
$$




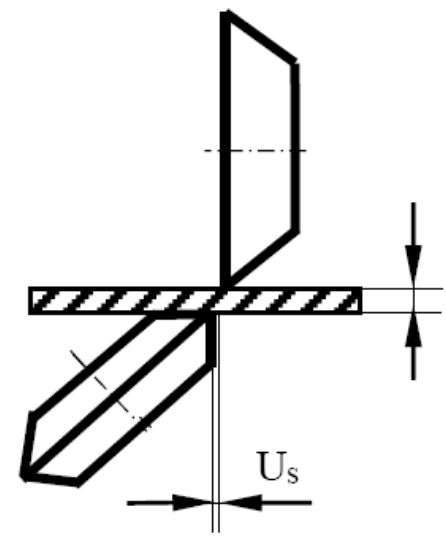

Gambar 2. Kelonggaran Potong

\subsection{Penentuan Daya Motor}

Daya motor dipengaruhi oleh gaya potong langsung dan gaya-gaya yang digunakan untuk menggerakkan komponen-komponen mesin seperti :Cutter, poros, roda gigi dan pulley .

Besar daya untuk menggerakkan komponen dirumuskan dengan persamaan:

$$
\mathrm{P}=\mathrm{F} . \mathrm{v}
$$

Dimana :

$$
\begin{aligned}
\mathrm{P} & =\text { Daya }(\text { Watt }) \\
\mathrm{F} & =\text { Gaya }(\mathrm{N}) \\
\mathrm{v} & =\text { Kecepatan linear }(\mathrm{m} / \mathrm{sec}) \\
& =\frac{\pi \cdot d \cdot n}{60} \\
\mathrm{n} & =\text { putaran }(\mathrm{rpm})
\end{aligned}
$$

\section{METODOLOGI}

Metodolgi penulisan jurnal ilmiah ini secara umum dijelaskan seperti pada diagram alir berikut:

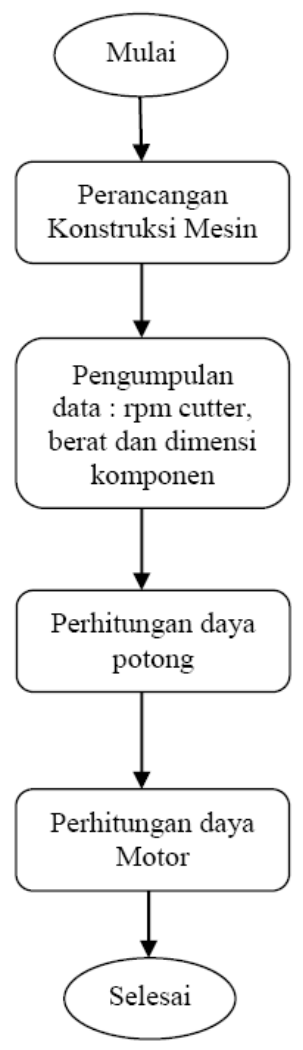

\section{PERANCANGAN}

\subsection{Gambaran Umum Mesin}

Mesin Potong Untuk Flange Packing adalah suatu alat yang digunakan untuk memotong asbes dengan hasil pemotongan bentuk melingkar. Meskipun sudah ada alat pemotong yang lain, namun alat ini mempunyai effisiensi dan efektifitas yang lebih tinggi serta modifikasi produknya lebih banyak.

Disini penulis tidak membahas secara detail desain dari mesin tersebut, tetapi hanya memberikan ilustrasi dan deskripsi secara umum bagian-bagian mesin dan cara kerja dari mesin tersebut.

\subsection{Gambaran Umum alat}

Komponen utama alat ini ditinjau dari prinsip kerjanya sebagai berikut:
1. Unit pemotong
2. Unit pencekaman
3. Unit pemutar
4. Unit rangka 


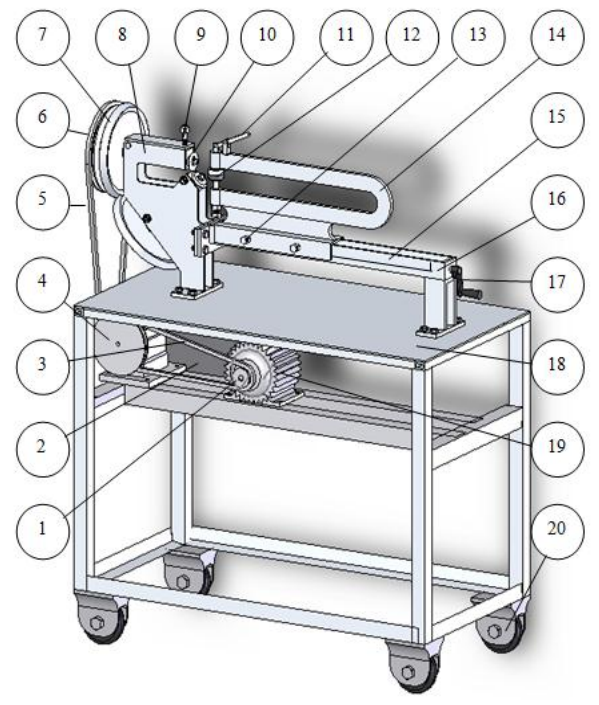

Gambar 3. Rancangan Mesin

Keterangan:

1. Pulley motor

2. Control Box

3. V-belt motor-reduser

4. Pulley reduser

5. V-belt reduser - poros cutter atas

6. Pulley poros cutter atas

7. Roda gigi kerucut

8. Rangka klemping

9. Tuas pemotong

10. cutter

11. Tuas kleping

12. Klem

13. Baut penjepit

14. Rangka klemping

15. Mistar

16. Alas dudukan rangka klemping

17. Engkol eretan

18. Meja dudukan mesin

19. Motor

20. Roda meja

\subsection{Penjelasan Masing-Masing Bagian}

\section{Unit pemotong}

Bagian ini terdiri dari dua buah cutter, yaitu cutter atas dan cutter bawah. Cutter atas dipasang pada poros pemutar (poros atas) dalam posisi horizontal. Sedangkan poros bawah dalam posisi miring dengan sudut $45^{\circ}$ dari poros pemutar. Hal ini dimaksudkan untuk mempermudah proses pemotongan yang berbentuk radius.

Spesifikasi bahan yang digunakan adalah Hard Alloy Tool steel:

$\begin{array}{ll}\text { Bahan pisau } & \text { : DIN 45SiCrV6 } \\ \text { Kekerasan } & : 57 \mathrm{HRC} \\ \text { Diameter maksimal } & : 50 \mathrm{~mm} \\ \text { Tebal } & : 10 \mathrm{~mm} \\ \text { Putaran Pisau potong } & : 10 \mathrm{rpm}\end{array}$

\section{Unit Pencekaman}

Adalah bagian yang berfungsi menjepit asbes agar tidak bergeser kedudukannya ketika dipotong. Sebelum dilakukan proses pemotongan asbes harus betul-betul terjepit dengan kuat pada unit klemping ini.

\section{Unit Rangka}

Unit rangka ini terdiri dari rangka unit pemotong, rangkaian pemutar dengan menggunakan motor listrik, rangka klemping dan landasan rangka klemping. Rangka ini terbuat dari kanal $\mathrm{U}$ dan pelat strip.

\subsection{Pengoperasian Mesin}

Proses mengoperasikan alat ini tidak sulit, karena menggunakan daya motor listrik sebagai pemutar dan tidak memerlukan keterampilan khusus. Proses pemotongan dilakukan dua kali untuk mendapatkan diameter luar dan diameter dalam.

Adapun pengoperasian alat ini adalah sebagai berikut:

1. Memberi tanda pada benda kerja yang akan dipotong dengan cara memberi titik center pada diameter lingkaran yang akan dibuat.

2. Memasang benda kerja dengan menempatkan titik center benda kerja tersebut pada unit pencekaman.

3. Atur posisi diameter asbes yang akan dipotong sesuai ukuran, dengan cara memutar engkol eretan kearah kanan. 
Secara otomatis rangka penjepit akan bergeser. Setelah posisi tepat kencangkan baut pengikat rangka penjepit.

4. Tekan tombol ON untuk menghidupkan motor agar pulley dapat bergerak memutar poros cutter sehingga kedua cutter dapat berputar dengan bantuan roda gigi kerucut. Lakukan pemotongan dengan cara menurunkan cutter atas sedikit demi sedikit.

5. Lakukan proses pemotongan ini sampai pelat betul-betul terpotong.

6. Tekan tombol OFF apabila proses pemotongan telah selesai.

7. Kendorkan baut pengikat rangka penjepit dan geser rangka penjepit serta lakukan proses pemotongan ulang untuk mendapatkan diameter dalam.

8. Lepas benda kerja dengan cara mengendorkan klemping dan menarik benda kerja.

\subsection{Kapasitas Mesin}

Alat pemotong flange packing ini didesain untuk memotong asbes dengan spesifikasi sebagai berikut:

$>$ Bahan lembaran: Graphite

> Tebal maksimal : $3 \mathrm{~mm}=0,118$ in

$>$ Radius maksimal asbes: $350 \mathrm{~mm}$

\subsection{Gear Box}

Gear Box (reducer) berfungsi untuk merubah putaran tinggi dari motor menjadi putaran rendah dengan bantuan susunan roda gigi. Gear Box mempunyai rasio perbandingan 1 : 10 yang digunakan untuk perbandingan perhitungan

\subsection{Pulldey Motor}

Pulley ini berfungsi meneruskan Output motor listrik (putaran) yang diteruskan pada pulley reduser input.

\subsection{Pulley Reducer}

Pulley ini berfungsi meneruskan putaran dari gear box ke pulley poros cutter atas.

\subsection{Pulley Cutter Poros Atas}

Pulley ini terletak pada ujung dari poros cutter atas yang berfungsi meneruskan putaran yang direduksi oleh pully reduksi.

\subsection{V-Belt}

V-Belt digunakan untuk mentransmisikan putaran motor ke reduser dan putaran reduser sampai ke poros cutter atas. Jenis sabuk yang diambil adalah jenis sabuk tipe-A.

\section{HASIL DAN PEMBAHASAN}

\subsection{Perhitungan Gaya Pemotongan}

Berdasarkan spesifikasi bahan asbes tebal $3 \mathrm{~mm}$ dengan harga kekuatan tarik (tensil strength) $45 \mathrm{~N} / \mathrm{mm}^{2}$.

$$
\begin{array}{cc}
\text { Dimana: } & \tau_{g}=(0,5-0,75) \sigma_{t} \\
\text { Maka: } \quad \tau_{g}=0,75 \times 45 \mathrm{~N} / \mathrm{mm}^{2} \\
\tau_{g}=33,75 \mathrm{~N} / \mathrm{mm}^{2}
\end{array}
$$

Cutter mengalami dua bentuk pemotongan yaitu pada saat cutter bergerak turun (potong tekan) dan pada saat cutter berputar (potong geser).

\section{a. Perhitungan Gaya Pemotongan Tekan (Punching)}

Pada kondisi ini merupakan proses Punching. Sehingga untuk mencari besar gaya punch cutter yaitu dengan menggunakan persamaan:

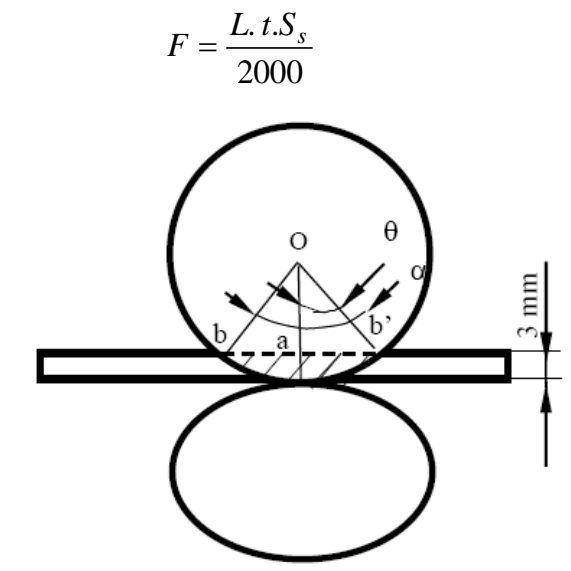

Gambar 4. Penetrasi Pemotongan Tekan 


$$
\begin{aligned}
\cos \theta & =\frac{o a}{o b}=\frac{22}{25}=0,88 \\
\theta & =28,3576^{\circ} \\
\alpha & =2 \theta=56,7152^{\circ}
\end{aligned}
$$

Menghitung Panjang Busur

$$
\begin{aligned}
& \mathrm{bb}^{\prime}=\frac{\alpha}{360} 2 . \pi \cdot r=24,7342 \mathrm{~mm}=0,9738 \text { in } \\
& \text { Maka: } \quad F=\frac{0,9738 \times 0,1181 \times 11029,4}{2000} \\
& =0,63 \text { ton } \\
& =6300 \mathrm{~N}
\end{aligned}
$$

\section{b. Perhitungan Gaya Pemotongan Geser (Shearing)}

Pada kondisi ini berlaku proses Shearing (pemotongan). Maka gaya shearing yang direduksi yaitu dengan persamaan:

$$
F_{s}=K . F \quad \text { dengan } K=\frac{t . P}{S}
$$

Dari persamaan diatas $F_{s}$ reduksi dapat diketahui karena " $S$ " telah diketahui :

$$
\begin{aligned}
& \mathrm{S}=10 \tan 45^{\circ}=10 \mathrm{~mm} \\
& \text { P, diambil } 60 \% \\
& \text { Maka: } \\
& F_{S}=\frac{t . P}{S} \times F \\
& \begin{aligned}
F_{s} & =\frac{0,118 \times 0,6}{0,394} \times 0,63 \text { ton } \\
& =0,1132 \text { ton } \\
& =113,2 \mathrm{~N}
\end{aligned}
\end{aligned}
$$

Jadi besar gaya pemotongan $\left(F_{s}\right)$ sebesar $113,2 \mathrm{~N}$

\subsection{Penentuan Daya Motor}

Daya motor dipengaruhi oleh bebanbeban yang bekerja yaitu antara lain: berat cutter, berat poros, berat pulley, berat gear dan gaya pemotongan .
Beban-beban yang bekerja:

A. Beban Pada Poros Atas

a) Beban karena berat poros dan cutter atas

$$
\begin{aligned}
\text { Beban } & =[(\text { Berat cutter }+ \text { Berat poros }) \times \text { kecepatan linier }] \\
& =\left[(0,98 \mathrm{~N}+19.62 \mathrm{~N}) \times \frac{\pi \cdot d \cdot n}{60}\right] \\
& =\left[(20,6 \mathrm{~N}) \times \frac{\pi \times 0,05 \mathrm{~m} \times 10 \mathrm{Rpm}}{60}\right] \\
& =0,54 \mathrm{Watt}
\end{aligned}
$$

b) Beban karena berat gear

Asumsi gear :

Berat $=7 \mathrm{~kg}$,

Jumlah gigi, $\mathrm{N}_{\mathrm{g}}=76$

Modul, $\mathrm{m}=3$

Sehingga diameter pitch gigi, $\mathrm{d}_{\mathrm{p}}=3 \times 76=228 \mathrm{~mm}$

Beban $=[($ Berat gear $) \mathrm{x}$ kecepatan linier $]$

$$
\begin{aligned}
& =\left[(68,67 \mathrm{~N}) \times \frac{\pi \cdot d p \cdot n}{60}\right] \\
& =\left[(68,67 \mathrm{~N}) \times \frac{\pi \times 0,228 \mathrm{~m} \times 10 \mathrm{Rpm}}{60}\right. \\
& =8,20 \mathrm{Watt}
\end{aligned}
$$

c) Beban karena gaya pemotongan

Beban $=[$ (gaya pemotongan $) \mathrm{x}$ kecepatan linier $]$

$$
\begin{aligned}
& =\left[(113,2 \mathrm{~N}) \times \frac{\pi \cdot d \cdot n}{60}\right] \\
& =\left[(113,2 \mathrm{~N}) \times \frac{\pi \times 0,05 \mathrm{~m} \times 10 \mathrm{Rpm}}{60}\right] \\
& =2,96 \mathrm{Watt}
\end{aligned}
$$

Beban yang bekerja pada poros atas adalah :

$$
=0,54 \mathrm{Watt}+8,20 \mathrm{Watt}+2,96 \mathrm{Watt}
$$$$
=11,7 \text { Watt }
$$

B. Beban Pada Poros Bawah

a. Beban karena berat poros dan cutter bawah

Asumsi berat poros : $2 \mathrm{~kg}=19,62 \mathrm{~N}$

Beban $=[$ (Berat cutter + Berat poros $) \mathrm{x}$ kecepatan linier $]$

$$
\begin{aligned}
& =\left[(0,98 \mathrm{~N}+19.62 \mathrm{~N}) \times \frac{\pi \cdot d \cdot n}{60}\right] \\
& =\left[(20,6 \mathrm{~N}) \times \frac{\pi \times 0,05 \mathrm{~m} \times 10 \mathrm{Rpm}}{60}\right] \\
& =0,54 \mathrm{Watt}
\end{aligned}
$$


b. Beban karena berat gear

Asumsi gear :

Berat $=7 \mathrm{~kg}$,

Jumlah gigi, $\mathrm{N}_{\mathrm{g}}=76$

Modul, $\mathrm{m}=3$

Sehingga diameter pitch gigi, $d_{p}=3 \times 76=228 \mathrm{~mm}$

Beban $\quad=[($ Berat gear $) \times$ kecepatan linier $]$

$=\left[(68,67 \mathrm{~N}) \times \frac{\pi \cdot d p \cdot n}{60}\right]$

$=\left[(68,67 \mathrm{~N}) \times \frac{\pi \times 0,228 \mathrm{~m} \times 10 \mathrm{Rpm}}{60}\right.$

$=8,20 \mathrm{Watt}$

\section{c. Beban karena gaya pemotongan}

Beban $=[$ (gaya pemotongan $) \mathrm{x}$ kecepatan linier $]$

$$
\begin{aligned}
& =\left[(113,2 \mathrm{~N}) \times \frac{\pi \cdot d \cdot n}{60}\right] \\
& =\left[(113,2 \mathrm{~N}) \times \frac{\pi \times 0,05 \mathrm{~m} \times 10 \mathrm{Rpm}}{60}\right] \\
& =2,96 \mathrm{Watt}
\end{aligned}
$$

Beban yang bekerja pada poros atas adalah :

$=0,54 \mathrm{Watt}+8,20 \mathrm{Watt}+2,96 \mathrm{Watt}$

$=11,7 \mathrm{Watt}$

\section{Beban Karena Berat Pulley \\ a. Pulley Poros Cutter Atas}

Asumsi berat pulley : $1,5 \mathrm{~kg}=14,72 \mathrm{~N}$

Beban $=[$ (Berat pulley $) \mathrm{x}$ kecepatan linier $]$

$$
\begin{aligned}
& =\left[(14,72 \mathrm{~N}) \times \frac{\pi \cdot d \cdot n}{60}\right] \\
& =\left[(14,72 \mathrm{~N}) \times \frac{\pi \times 0,14 m \times 10 \mathrm{Rpm}}{60}\right] \\
& =1,08 \mathrm{Watt}
\end{aligned}
$$

b. Pulley output reducer

Asumsi berat poros: $1 \mathrm{~kg}=9,81 \mathrm{~N}$

$$
\begin{aligned}
\text { Beban } & =\left[(9,81 \mathrm{~N}) \times \frac{\pi \cdot d \cdot n}{60}\right] \\
& =\left[(9,81 \mathrm{~N}) \times \frac{\pi \times 0,05 m \times 28 R p m}{60}\right] \\
& =0,72 \mathrm{Watt}
\end{aligned}
$$

\section{c. Pulley input Reducer}

Asumsi berat poros $=2 \mathrm{~kg}=19,62 \mathrm{~N}$

Beban $=[$ (Berat pulley $) \mathrm{x}$ kecepatan linier $]$

$$
=\left[(19,62 \mathrm{~N}) \times \frac{\pi \cdot d \cdot n}{60}\right]
$$

Beban $=[$ (Berat pulley $) \mathrm{x}$ kecepatan linier $]$

$$
\begin{aligned}
& =\left[(19,62 \mathrm{~N}) \times \frac{\pi \times 0,16 \mathrm{~m} \times 280 \mathrm{Rpm}}{60}\right] \\
& =46 \text { Watt }
\end{aligned}
$$

\section{d. Pulley pada motor}

Asumsi berat poros : $0,75 \mathrm{~kg}=7,36 \mathrm{~N}$

Beban $=[($ Berat pulley $) \mathrm{x}$ kecepatan linier $]$

$$
\begin{aligned}
& =\left[(7,36 \mathrm{~N}) \times \frac{\pi \cdot d \cdot n}{60}\right] \\
& =\left[(7,36 \mathrm{~N}) \times \frac{\pi \times 0,03 m \times 1400 R p m}{60}\right] \\
& =16,19 \mathrm{Watt}
\end{aligned}
$$

Jadi beban total karena berat pulley:

$=1,08 \mathrm{Watt}+0,72 \mathrm{Watt}+46 \mathrm{Watt}+16,19 \mathrm{Watt}$ $=64 \mathrm{Watt}$

Jadi beban total yang harus dikeluarkan oleh motor:

$\mathrm{P}=$ (Beban Pada Poros Atas $)+($ Beban Pada

Poros Atas) + (Beban Karena Berat Pulley)

$=11,7$ Watt $+11,7$ Watt +64 Watt

$\mathrm{P}=87,4$ Watt

Daya motor yang diperlukan adalah :

$$
\mathrm{P}_{\mathrm{m}}=\frac{P}{\eta_{m}}
$$

Jika $\eta_{m}$ dipilih sebesar $90 \%$, maka daya motor yang diperlukan sebesar :

$$
\begin{aligned}
P_{m} & =\frac{100}{90} \times 87,4 \text { Watt } \\
& =97,11 \text { Watt }
\end{aligned}
$$

Karena : $1 \mathrm{Hp}=746$ Wattt

Maka daya motor dalam $\mathrm{Hp}$ sebesar :

$$
P_{\text {act }}=\frac{97,11}{746}=0,13 \mathrm{Hp}
$$

\section{KESIMPULAN DAN SARAN}

Konstruksi mesin pemotong graphite packing ini didesain cukup sederhana dan mudah dalam pengoperasiannya. Setelah Graphite packing diseting pada pencekam, 
mesin bisa dijalankan dengan menghidupkan motor listrik dan pemotonganpun dimulai.

Dari hasil perhitungan daya pemotongan graphite packing, daya pemotongan langsung relatif kecil yaitu sebesar 23,4 Watt dibanding dengan daya yang digunakan untuk menggerakan komponen-komponen mesin yaitu sebesar 64 Watt. Daya untuk menngerakkan komponen ini merupakan daya yang tidak memberikan nilai tambah, sehingga perlu dilakukan rekayasa untuk meminimalkan daya tersebut.

Salah satu cara meminimalkan daya yang diakai untuk menggerakan komponen adalah melakukan analisa kekuatan terhadap komponen-komponen mesin. Dari hasil analisa ini akan didapatkan dimensi minimal dari masing-masing komponen. Dimensi minimal ini akan berkorelasi langsung terhadap penurunan daya yang digunakan untuk menggerakannya.
Untuk itu kami menyarankan agar jurnal ini lebih disempurnakan lagi dengan melakukan analisa kekuatan komponen.

\section{DAFTAR PUSTAKA}

H.W Pollack, Tool Design, Prentise Hall inc. New Jersey 07632, 1976

Klinger,.Product Catalog Industrial Sealing

Niemann G. 1994, Elemen Mesin Jilid 1, Jakarta, Erlangga

R.S.Khurmi, J.K. Gupta, 1982, AText Book Of Machine Design, New Delhi, Eurasia Publishing House.

Sularso, Kiyokatsu Suga, Dasar Perancangan Dan Pemilihan Elemen Mesin. 


\title{
PROTOTYPE SISTEM INFORMASI KINERJA PEGAWAI APARATUR PEMERINTAHAN PADA KANTOR KECAMATAN SUKADIRI KABUPATEN TANGERANG
}

\author{
Mahpud 1), Syamsul Bahri 2) \\ 1) Program Studi Teknik Informatika \\ Fakultas Teknik \\ Universitas Muhammadiyah Tangerang \\ J. Perintis Kemerdekaan I/33, Cikokol Kota Tangerang \\ http://www.umt.ac.id \\ mahpuds@yahoo.com \\ 2) Program Studi Teknik Mesin \\ Fakultas Teknik \\ Universitas Muhammadiyah Tangerang \\ Jl. Perintis Kemerdekaan I/33, Cikokol Kota Tangerang \\ http://www.umt.ac.id
}

\begin{abstract}
ABSTRAK
Sub bagian Kepegawaian Kecamatan Sukadiri adalah suatu instansi di lingkup pemerintahan Kantor Kecamatan Sukadiri Kabupaten Tangerang yang memberikan pendidikan dan pelatihan untuk pegawai di lingkungan pemerintahan Kecamatan Sukadiri Kabupaten Tangerang. Dalam pengolahan data kepegawaiannya belum menggunakan sarana komputer untuk menyimpan dan memproses data mengenai kinerja pegawai, sehingga selam ini sering mengalami keterlambatan dalam memperoleh laporan yang berhubungan dengan kinerja pegawai. Maka untuk mengatasi masalah diatas, penulis mencoba membuat suatu Prototype sisitem Informasi Kinerja Pegawai Aparatur Pemerintahan Pada Kantor Kecamatan Sukadiri Kabupaten Tangerang menggunakan pemrograman php MySQL, yang menghasilkan file data point penilaian, file data pegawai dan file data penilaian serta laporan-laporan yang diharapkan dapat membantu terutama di bagian kepegawain pada Kantor Kecamatan Sukadiri Kabupaten Tangerang.
\end{abstract}

Kata Kunci : Pegawai, Kinerja

\section{PENDAHULUAN}

\section{Latar Belakang Masalah}

Perkembangan dunia teknologi dewasa ini semakin berkembang dengan sangat cepat. Hal ini yang mendorong para pelaku bisnis untuk beroperasi dan berkompetensi. Kebutuhan akan informasi sangat di perlukan sekali dalam memberikan pelayanan terhadap suatu perusahaan atau instansi pemerintah karena informasi ini dianggap sebagai salah satu acuan dalam suatu perusahaan atau instansi pemerintah untuk mencapai tujuan. Seiring dengan kemajuan teknologi saat ini, pemakaian computer dalam mengolah informasi merupakan suatu kebutuhan yang sangat penting.

Penilaian kinerja Pegawai Negeri Sipil, adalah penilaian secara periodik pelaksanaan pekerjaan seorang Pegawai Negeri Sipil. Tujuan penilaian kinerja adalah untuk 
mengetahui keberhasilan atau ketidak berhasilan seorang Pegawai Negeri Sipil, dan untuk mengetahui kekurangan-kekurangan dan kelebihan-kelebihan yang dimiliki oleh Pegawai Negeri Sipil yang bersangkutan dalam melaksana-kan tugasnya. Hasil penilaian kinerja digunakan sebagai bahan pertimbangan dalam pembinaan Pegawai Negeri Sipil, antara lain untuk : kenaikan pangkat, pengangkatan dalam jabatan, serta pemberian penghargaan. Penilaian kinerja Pegawai Negeri Sipil dilaksanakan berdasarkan Peraturan Pemerintah Nomor 10 Tahun 1979 tentang Penilaian Pelaksanaan Pekerjaan Pegawai Negeri Sipil. Unsur-unsur yang dinilai dalam melaksanakan penilaian pelaksanaan pekerjaan adalah Kesetiaan, Prestasi Kerja, Tanggung Jawab, Ketaatan, Kejujuran, Kerjasama, Prakarsa dan Kepimpinan.

Untuk menangani tugas-tugas Pemerintahan Kecamatan perlu adanya aparat Pemerintahan Kecamatan yang berkualitas dan mempunyai dedikasi, jiwa pengabdian yang tinggi, yang diperlukan dalam rangka pelayanan kepada masyarakat terutamanya pelayanan administrasi, dan sumber informasi data yang akurat, serta pelaporan-pelaporan yang cepat dan tepat. Untuk itu pemerintah telah banyak melakukan kegiatan seperti mengadakan pendidikan dan pelatihan (Diklat) kepada pegawai negeri, menaikkan gaji dan tunjangannya,

Dilihat dari sistem pemerintahan Indonesia merupakan ujung tombak dari pemerintahan daerah yang langsung berhadapan dengan masyarakat luas. Citra birokrasi pemerintahan secara keseluruhan akan banyak ditentukan oleh kinerja organisasi tersebut. Kantor Kecamatan sebagai instansi pelayanan publik dituntut untuk memperbaiki dan senantiasa melakukan reformasi serta mengantisipasi perkembangan masyarakat yang terjadi. Dalam rangka meningkatkan citra, kerja dan kinerja instansi pemerintah menuju kearah Professionalisme dan menunjang terciptanya pemerintahan yang baik (good governance), perlu adanya penyatuan arah dan pandangan bagi segenap jajaran pegawai Pemerintah yang dapat dipergunakan sebagai pedoman atau acuan dalam melaksanakan tugas, baik manajerial maupun operasional diseluruh bidang tugas dan unit organisasi Instansi Pemerintah secara terpadu.

Adapun di Kantor Kecamatan Sukadiri memiliki Daftar Urut Kepangkatan ( DUK ). DUK bertujuan untuk memperjelas dari kerangka jabatan struktural yang berada di Kantor Kecamatan Sukadiri. Beberapa Nama Jabatan Struktural yang berada di Kantor Kecamatan Sukadiri yaitu Camat, Sekertaris Camat, Pelaksana, Kasi Pengembangan Ekonomi \& UKM, Kasi Kesejahteraan Sosial, Pelaksana pada ketentraman, Kasi Ketentraman dan Ketertiban Umum, Kasi Pemerintahan, Kasubag Perencanaan \& Keuangan, Kasubag Umum \& Kepegawaian, Kasi Pembangunan, Pelaksana Pada Kasi Pemerintahan, dll.

Dari Latar Belakang Pendidikan Pegawai Kantor Kecamatan Sukadiri terdiri dari beragam latar belakang pendidikan yaitu untuk Pegawai yang memiliki latar Belakang Pendidikan S1 terdapat 9 orang Pegawai, S2 terdapat 5 orang Pegawai, Jenjang Diploma terdapat 1 orang Pegawai, SMA/Sederajat terdapat 21 orang Pegawai dan SLTP/SMP terdapat 2 orang Pegawai.

Kantor Kecamatan Sukadiri adalah suatu Instansi Pemerintah Kabupaten Tangerang Terletak di sebelah Utara (pantura) dengan luas Wilayah 2.414.665 Hektar. Dengan perbatasan sebelah Utara Laut Jawa, sebelah Timur Kecamatan Pakuhaji sebelah Barat Kecamatan Mauk sebelah Selatan Kecamatan Rajeg. Dalam sistem pengolahan data kependudukan pada Kantor Kecamatan Sukadiri diperlukan sistem yang memadai dan dapat memberi kepuasan bagi pegawai dan masyarakat kecamatan sukadiri. 


\section{Rumusan Masalah}

Berdasarkan latar belakang dan berdasarkan pengamatan yang dilakukan oleh penulis, maka dapat diuraikan beberapa permasalahan yang dihadapi, antara lain:

1. Bagaimanakah sistem informasi penilaian kinerja aparatur pegawai pada kantor Kecamatan Sukadiri Kabupaten Tangerang yang berjalan saat ini?

2. Apakah sistem informasi kinerja pegawai aparatur pemerintahan pada Kecamatan Sukadiri Kabupaten Tangerang yang berjalan saat ini sudah efektif dan efisien?

3. Apakah sistem informasi kinerja pegawai aparatur pemerintahan pada kantor Kecamatan Sukadiri Kabupaten Tangerang yang berjalan saat ini sudah mampu memberikan laporan secara cepat dan akurat?

\section{Tujuan Penelitian}

Adapun tujuan dari Prototype Sistem Informasi Kinerja Pegawai Aparatur Pemerintahan Pada Kantor Kecamatan Sukadiri Kabupaten Tangerang ini adalah sebagai berikut :

1. Mengetahui sistem informasi kinerja pegawai aparatur pemerintahan pada kantor Kecamatan Sukadiri Kabupaten Tangerang yang berjalan saat ini.

2. Menciptakan prototype sistem informasi pegawai aparatur pemerintahan pada kantor Kecamatan Sukadiri Kabupaten Tangerang yang efektif dan efisien.

Memberikan solusi yang terbaik berkaitan dengan masalah kinerja aparatur pemerintahan.

\section{Manfaat Penelitian}

Manfaat atau kegunaan dari Prototype Sistem Informasi Kinerja Pegawai Aparatur Pemerintahan Pada Kantor Kecamatan
Sukadiri Kabupaten Tangerang ini adalah sebagai berikut :

1. Memberikan solusi sistem informasi penilaian kinerja pegawai aparatur pemerintahan pada kantor Kecamatan Sukadiri Kabupaten Tangerang dalam bentuk pototype.

2. Bagi Penulis, penelitian ini merupakan usaha untuk meningkatkan kemampuan berfikir melalui penulisan karya ilmiah.

3. Bagi Kantor Kecamatan Sukadiri Kabupaten Tangerang, khususnya para aparatur pemerintah, penelitian ini bermanfaat sebagai sumbangan pemikiran dalam pelaksanaan pelayanan publik.

\section{LANDASAN PEMIKIRAN \\ Pengertian sistem}

Definisi sistem terdapat beberapa pandangan, diantaranya yaitu :

1) Menurut Agus Mulyanto ( 2009 ), Sistem dapat diartikan sebagai kumpulan dari elemen-elemen yang berinteraksi untuk mencapai suatu tujuan sebagai satu kesatuan. Dalam bidang sistem informasi, sistem diartikan sebagai sekelompok komponen yang saling berhubungan, bekerja sama untuk mencapai tujuan bersama dengan menerima input serta menghasilkan output dalam proses transformasi yang teratur.

2) Menurut Wiki ( 2009 ), Sistem diambil dari asal mula sistem yang berasal dari bahasa latin (systema) dan bahasa yunani (sustema) yang memiliki pengertian bahwa suatu sistem merupakan suatu kesatuan yang didalamnya terdiri dari komponen atau elemen yang berhubungan satu dengan yang lainnya yang berfungsi untuk memudahkan aliran informasi, materi atau energi. Istilah ini sering dipergunakan untuk menggambarkan suatu set entitas yang berinteraksi. 
3) Menurut Kerz ( 2009 ), Sistem yaitu gabungan dari sekelompok komponen baik itu manusia atau bukan manusia (non-human) yang saling mendukung satu sama lain serta diatur menjadi sebuah kesatuan yang utuh untuk mencapai tujuan, sasaran bersama atau hasil akhir.

Dari definisi di atas dapat disimpulkan bahwa sistem adalah suatu kumpulan atau kelompok dari elemen atau komponen yang saling berhubungan atau saling berinteraksi dan saling bergantung satu sama lain untuk mencapai tujuan tertentu.

\section{Pengertian Informasi}

Menurut Rainer (2007:5), Informasi merupakan data yang diatur dan disusun sehingga memiliki arti dan nilai bagi penerima.

Menurut O'Brien dan Marakas (2008:32), Informasi merupakan data yang telah dikonversi ke dalam bentuk yang lebih berguna dan berarti kepada pengguna akhir tertentu.

Dari pengertian di atas dapat disimpulkan bahwa informasi merupakan data yang telah dikonversi dengan susunan dan aturan tertentu sehingga memiliki arti dan nilai yang berguna bagi penerimanya.

\section{Pengertian Sistem Informasi}

Menurut Laudon and Laudon (2010:46), Sistem informasi dapat didefinisikan secara teknis sebagai sekumpulan komponen-komponen yang saling berhubungan yang mengumpulkan (mendapatkan kembali), memproses, menyimpan, dan mendistribusikan informasi untuk mendukung pengambilan dan pengontrolan keputusan dalam suatu organisasi.

Menurut O'Brien dan Marakas (2008:4), Sistem informasi adalah gabungan dari orang, hardware, software, jaringan komunikasi, sumber daya data, dan kebijakan dan prosedur yang menyimpan, mengumpulkan (mendapatkan kembali), mengubah, dan mendistribusikan informasi dalam suatu organisasi.

Dari pengertian di atas dapat diambil kesimpulan bahwa sistem informasi adalah gabungan dari orang, hardware, software, jaringan komunikasi, sumber daya data, dan kebijakan dan prosedur yang menyimpan, mengumpulkan (mendapatkan kembali), memproses, dan mendistribusikan informasi untuk mendukung pengambilan dan pengontrolan keputusan dalam suatu organisasi.

\section{Konsep Dasar Pengertian Pegawai Negeri, Pegawai, Pengertian ASN, Tujuan ASN, Perbedaan ASN dengan PNS dan Penilaian Kinerja}

1. Pengertian Kinerja

Istilah kinerja menurut Anwar (2001:67) berasal dari kata Job Performance atau Actual Performance (prestasi kerja atau prestasi sesungguhnya yang dicapai oleh seseorang). Kinerja didefinisikan sebagai kontribusi terhadap hasil akhir organisasi dalam kaitannya dengan sumber yang dihabiskan dan harus diukur dengan indikator kualitatif dan kuantitatif. Maka pengembangan

instrument dilakukan untuk menilai persepsi pekerjaan akan kinerja diri mereka sendiri dalam kaitannya dengan item-item seperti output, pencapaian tujuan, pemenuhan deadline, penggunaan jam kerja dan ijin sakit.

Menurut Moeheriono (2009 : 60 ), Kinerja juga dapat diartikan sebagai suatu gambaran mengenai tingkat pencapaian pelaksaan suatu program kegiatan atau kebijakan mewujudkan sasaran, tujuan, visi dan misi organisasi yang dituangkan melalui perencanaan strategis suatu organisasi.

Dengan demikian dapat disimpulkan bahwa kinerja pegawai merupakan prestasi 
kerja yang dicapai oleh pegawai pada periode waktu tertentu dalam melaksanakan tugasnya, sesuai dengan tanggung jawab yang diberikan dalam mencapai tujuan organisasi.

\section{Pengertian Pegawai}

Menurut A.W. Widjaja (2006:113), Pegawai adalah merupakan tenaga kerja manusia jasmaniah maupun rohaniah (mental dan pikiran) yang senantiasa dibutuhkan dan oleh karena itu menjadi salah satu modal pokok dalam usaha kerja sama untuk mencapai tujuan tertentu (organisasi). Selanjutnya A.W. Widjaja mengatakan bahwa, pegawai adalah orangorang yang dikerjakan dalam suatu badan tertentu, baik di lembaga-lembaga pemerintah maupun dalam badan-badan usaha

Menurut Revida (2009:9), berdasarkan Undang-Undang No 43 Tahun 1999 jika dilihat dari defenisi maka ada empat unsur yang menjadi perhatian utama:

a. Memenuhi syarat tertentu, syarat untuk menjadi pegawai ditentukan dalam peraturan pemerintah berupa usia, indeks prestasi komulatif dan lain-lain.

b. Diangkat oleh pejabat yang berwenang. Diangkat oleh kepala instansi yang bersangkutan dengan Surat Keputusan (SK) yang mencantumkan pangkat dan golongan.

c. Diserahi tugas. Untuk menjalankan tugas pemerintah dan pembangunan sesuai dengan tugas pokok dan fungsi yang telah ditetapkan.

d. Digaji penggajian untuk Pegawai Negeri Sipil berlaku secara nasional.

Pengertian Pegawai Negeri Sipil dalam ketentuan Pasal 1 ayat (1) Undang- Undang Nomor 43 Tahun 1999, tentang Perubahan Atas Undang- Undang Nomor 8 Tahun 1974, Tentang Pokok- Pokok Kepegawaian, disebutkan bahwa Pegawai Negeri Sipil (PNS) adalah setiap warga negara Republik Indonesia yang telah memenuhi syarat yang telah ditentukan, diangkat oleh pejabat berwenang, dan diserahi tugas lainnya. Kemudian pejabat yang berwenang, adalah pejabat yang mempunyai kewenangan mengangkat, memindahkan dan memberhentikan pegawai negari berdasarkan peraturan perundangundangan yang berlaku. Dari perumusan ini terdapat empat unsur penting untuk menyatakan seseorang sebagai PNS:

Memenuhi syarat yang ditentukan dalam peraturan perundangan yang berlaku

a. Diangkat oleh pejabat yang berwenang

b. Diserahi tugas dalam suatu Jabatan Negara atau Tugas Negara lainnya, yang ditetapkan oleh perundang- undangan yang berlaku

c. Digaji menurut peraturan perundangan yang berlaku

Dalam penjelasan Pasal 2 ayat (2) dan ayat (3), Undang- Undang tersebut juga menjelaskan bahwa pegawai negeri terdiri dari Pegawai Negeri Sipil Pusat dan Pegawai Negeri Sipil Daerah. Pegawai Negeri Sipil Pusat merupakan Pegawai Negeri Sipil yang gajinya dibebankan pada anggaran pendapatan dan belanja negara. Sedangkan Pegawai Negeri Sipil Daerah, yang gajinya dibebankan pada anggaran pendapatan dan belanja daerah.

Pegawai Negeri Sipil sebagai unsur aparatur negara, harus diberikan pengembangan dan penyempurnaan sistem kerja dalam menghadapi tugas yang semakin berat dalam pelaksaan dan keberhasilan pembangunan. Dalam hal ini kedudukan Pegawai Negeri Sipil menjadi sangat penting, sebab lancar atau tidaknya pemerintahan den pembangunan negara, tidak terlepas dari peranan dan keikutsertaan Pegawai Negeri. 


\section{Pengertian Pegawai Negeri Sipil}

Menurut Salam (2004:175), Pegawai Negeri Sipil adalah setiap warga Negara Indonesia yang telah memenuhi syarat yang telah ditentukan, diangkat oleh pejabat yang berwenang an diserahi tugas dalam suatu jabatan negeri atau diserahi tugas Negara lainnya dan digaji berdasarkan UU Nomor 43 Tahun 1999 Tentang Pegawai Negeri.

\section{Aparatur Sipil Negara ( ASN )}

ASN adalah profesi pegawai negeri sipil dan pegawai tidak tetap pemerintah yang bekerja pada instansi dan perwakilan, dan diangkat

oleh pejabat berwenang, dan digaji sesuai dengan undang-undang. Namun dalam hal ini, RUU tentang pergantian nama PNS menjadi ASN masih menunggu keputusan dari DPR.

\section{Tujuan ASN}

Tujuan dirubahnya nama PNS menjadi ASN ini, agar nantinya para abdi Negara bisa lebih professional dan netralismenya tinggi. Untuk mewujudkan tujuan nasional, dibutuhkan pegawai Aparatur Sipil Negara. Pegawai Aparatur Sipil Negara diserahi tugas untuk melaksanakan tugas pelayanan publik, tugas pemerintahan dan tugas pembangunan tertentu.

\section{Perbedaan ASN dengan PNS}

Adapun perbedaannya adalah ASN tidak akan menerima uang pensiun lagi, seperti para PNS sebelumnya, melainkan hanya akan diberi pesangon satu kali saja jika sudah masuk pada umur pensiun. Ya seperti para pegawai swasta, hanya dapat pesangon saja.

\section{PEMBAHASAN}

\section{Prosedur Sistem}

\section{Persiapan}

a. Melakukan sosialisasi penilaian kerja kepada para pegawai Kecamatan Sukadiri Kabupaten Tangerang. b. Menyiapkan instrument pendukung penilaian kinerja yan disesuaikan dengan dengan jumlah keperluan penilaian

\section{Pelaksanaan Penilaian}

a. Penilaian dilaksanakan oleh staff kepegawaian yang di tunjuk secara khusus oleh Kabag. Kepegawaian untuk menjadi admin.

b. Admin mengoperasikan sistem dengan cara memasuki area halaman login terlebih dahulu.

c. Setelah login admin akan mulai melakukan penilaian kepada semua pegawai melalui instrument-instrument yang telah di tetapkan sebelumnya.

d. Hasil dari dari laporan penilaian kinerja tersebut dapat dilihat oleh para pegawai melalui sistem kinerja pegawai, dengan cara login ke dalam sistem dengan level sebagai pengguna.

\section{Verifikasi Data}

Data hasil penilaian yang sudah diperoleh perlu diverifikasi untuk kebenarannya, verifikasi data dapat dilakukan dengan berbagai cara, misalnya dengan melakukan wawancara kepada pegawai yang bersangkutan, atau melakukan wawancara saksi-saksi terkait. Sistem Yang Berjalan Saat Ini Untuk menganalisis sistem yang berjalan, pada penelitian ini digunakan program unified modeling language (uml) untuk menggambarkan prosedur dan proses yang berjalan saat ini, sebagai berikut : 


\section{Use Case Diagram}

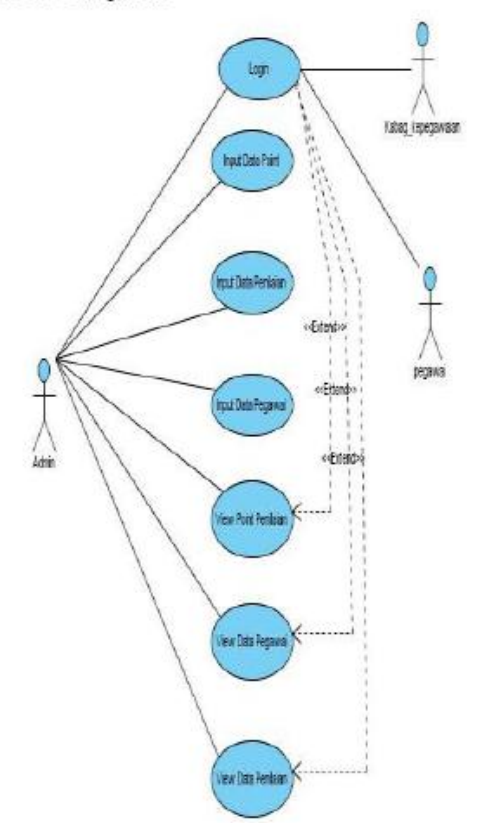

Gambar 3.2 Analisa sistem yang berjalan Pada Use Case Diagram

a. 1 sistem yang mencakup seluruh kegiatan pengolahan data pegawai dan penilaian kinerja pegawai.

b. 3 aktor yang melakukan kegiatan, diantaranya admin, Kabag. Kepegawaian dan pegawai.

c. 7 use case yang biasa dilakukan oleh admin tersebut diantaranya login, input data point, input data penilaian, input data pegawai, view point peniliaian, view data pegawai, view data penilaian.

\section{Activity Diagram Admin}

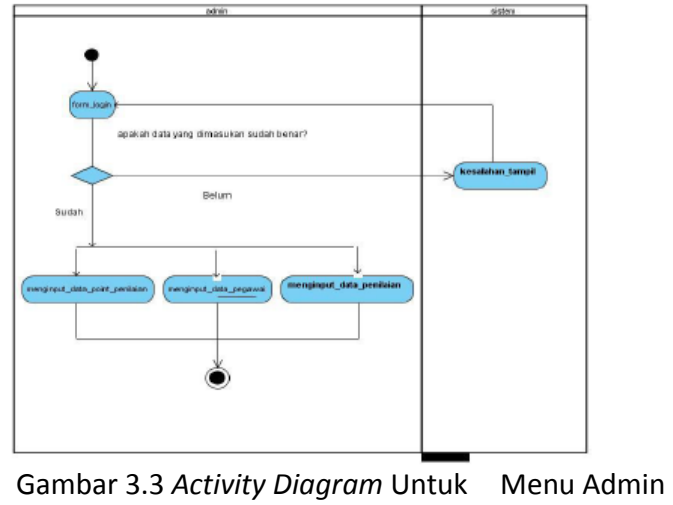

a. 1 Initial Node

b. 5 Action

c. 1 Decision Node

d. 1 Activity final Node

\section{Activity Diagram Pegawai}

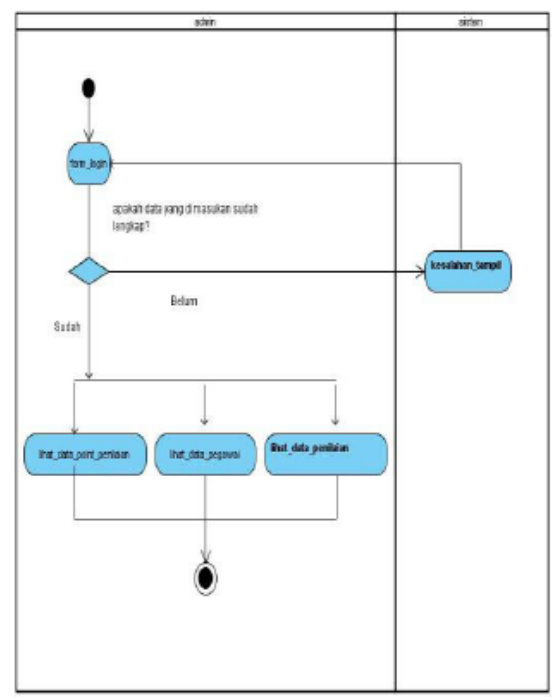

Gambar 3.4 Activity Diagram Untuk Menu Pegawai
a. 1 Initial Node
b. 5 Action
c. 1 Decision Node
d. 1 Activity final Node

\section{Diagram Class}




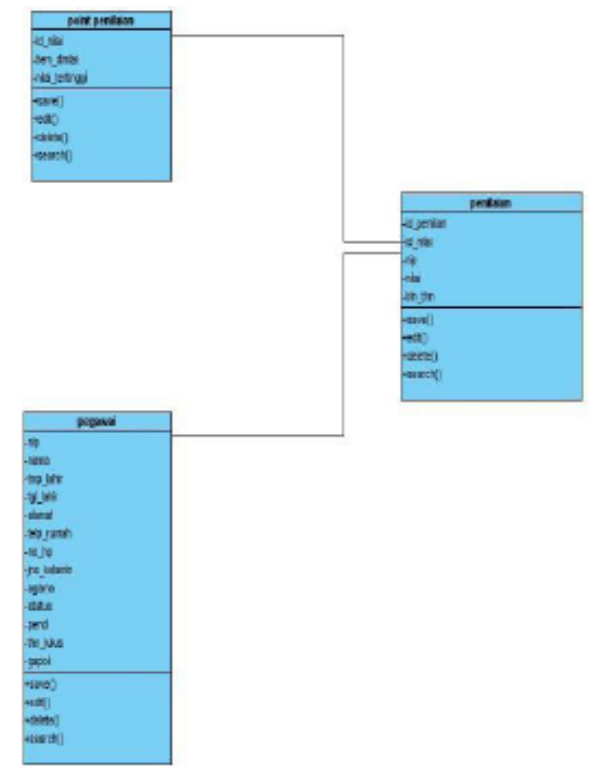

Gambar 3.5 Diagram Class Untuk

\section{Menggambarkan Tabel}
a. 2 Primary key
b. 21 Atributte
c. 12 Operation

\section{Sequence Diagram Admin}

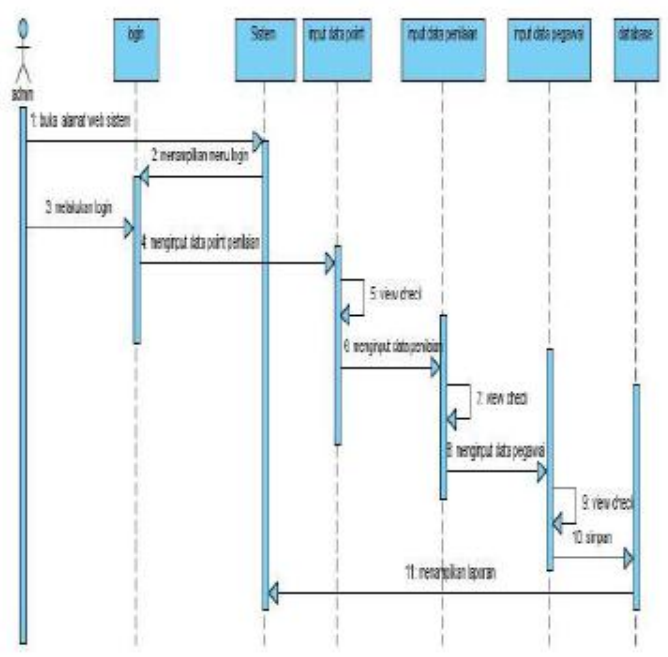

Gambar 3.6 Sequence Diagram Admin
a. 1 Aktor
b. 6 Lifeline
c. 11 message

\section{Sequence Diagram User}

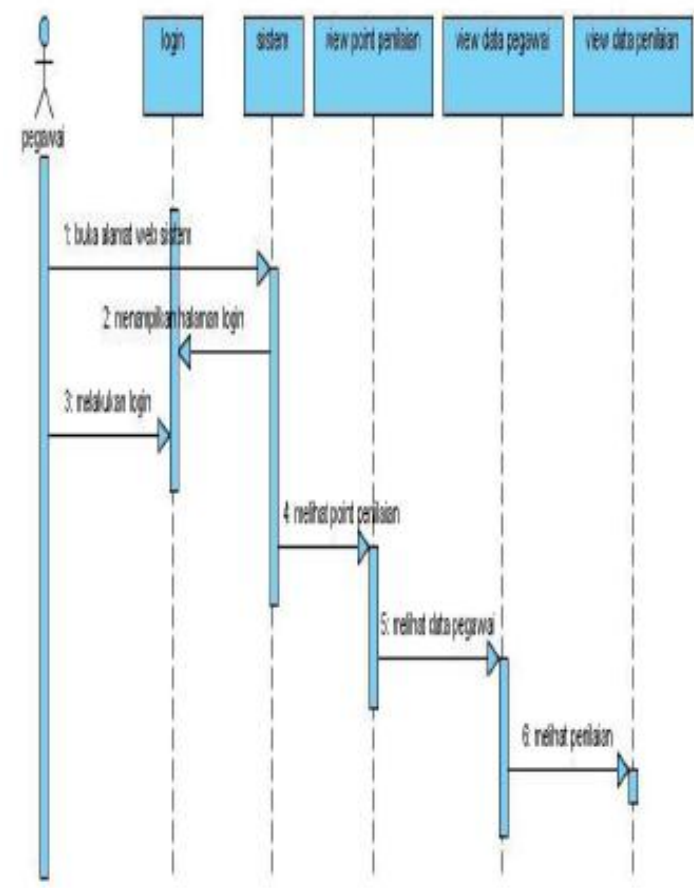

Gambar 3.7 Sequence Diagram User
a. 1 Aktor
b. 5 Lifeline
c. 6 Message

Menu Masukan adalah menu proses seluruh entri data dalam kegiatan penilaian pegawai, yang terdiri dari beberapa sub menu :

1. Aplikasi Penilalian Kinerja Pegawai

Cara membuka aplikasi Sistem Penilaian Kinerja Pegawai, sebagai berikut :

a. Komputer client yang digunakan telah terhubung dengan server.

b. Buka Mozilla Firefox Setup 12.0 dengan cara klik dua kali (doubleclick) pada logonya Bila Address pada Internet Properties telah ditentukan dengan http://localhost//nilai_kepegawaian/logi n.php.

\section{Login}

Halaman Login ini merupakan bagian dari halaman utama atau halaman index, halaman ini berfungsi sebagai halaman untuk 
Login atau masuk ke menu tertentu, user atau admin jika telah melakukan Login dan berhasil masuk, maka mereka akan diarahkan ke menunya masing - masing.

\section{Home}

Merupakan tampilan awal yang pertama tampil ketika situs dibuka. Berisi beberapa submenu yang apabila diklik maka akan tampil halaman submenu tersebut, submenu tersebut memiliki fungsi sesuai dengan nama title halaman tersebut.

\section{Profile}

Berisi Profil salah satu media Public Relation yang bertujuan untuk memperkenalkan sebuah Pemerintahan dan organisasi.

\section{Visi Dan misi}

Halaman visi misi ini merupakan bagian dari halaman utama atau halaman index, halaman ini menampilkan apa - apa saja visi misi yang terdapat di Kecamatan Sukadiri.

\section{Buku Tamu}

Berisi Menu ini berisi informasi pengunjung dan juga sebagai masukan untuk admin atas komentar-komentar yang diberikan. Jika user ingin menelusuri informasi yang lain maka dapat memilih menu yang lain satu-persatu, apabila telah cukup memperoleh informasi maka user dapat memilih keluar atau logout dari website.

\section{Informasi}

Berisi pesan (ucapan atau ekspresi) atau kumpulan pesan yang terdiri dari order sekuens dari simbol, atau makna yang dapat ditafsirkan dari pesan atau kumpulan pesan. Informasi dapat direkam atau ditransmisikan.

\section{Halaman Form Penilaian}

Form penilaian ini berfungsi untuk memasukan data - data penilaian. Form ini terdiri dari 5 buah field yaitu id penilaian, id point penilaian, nip, nilai dan bulan tahun penilaian. Setelah admin memasukan field field yang ada dan kemudian menekan tombol submit, maka data - data yang telah dimasukan tersebut akan disimpan ke dalam tabel point penilaian.

\section{Halaman Form Edit Penilaian}

Form Edit Penilaian ini berfungsi untuk memperbaiki dan menghapus data - data point penilaian yang telah di input melalui form data point penilaian agar suatu data dapat terhindar dari kesalahan - kesalahan.

\section{Sub Menu Laporan}

Sub menu ini merupakan sub menu yang menampilkan laporan - laporan yang ada pada sistem informasi kinerja pegawai pada Kecamatan Sukadiri Kabupaten Tangerang. Sub menu laporan ini terdiri dari laporan point penilaian, laporan pegawai dan laporan penilaian

11. Halaman Laporan Pegawai dan Penilaian Halaman Laporan pegawai ini merupakan output dari seluruh data penilaian pegawai yang sebelumnya telah di entry oleh admin melalui form pegawain dan penilaian.

\section{Halaman Laporan Point Penilaian}

Halaman Laporan point penilaian ini merupakan output dari seluruh data point penilaian uang sebelumnya telah di entry oleh admin melalui form point penilaian. 


\section{Rancangan Prototype / Tampilan Yang Diusulkan}

1. Rancangan Prototype Tampilan Awal Loin

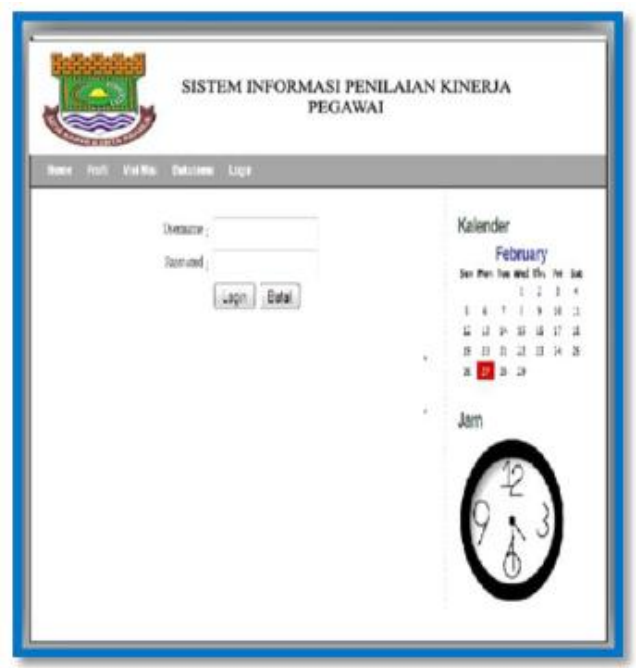

Gambar 3.8. Tampilan Awal Login

2. Rancangan Prototype Tampilan Menu Profil

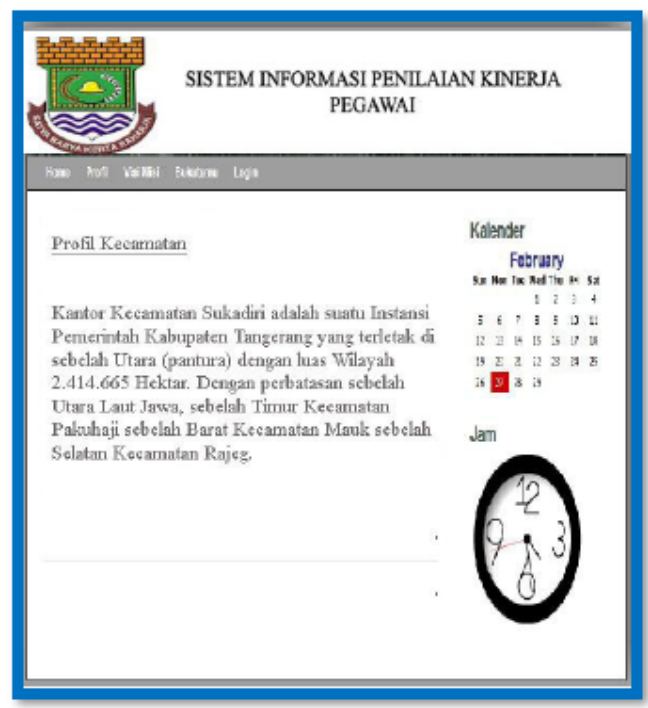

Gambar 3.9. Tampilan Menu Profil
3. Rancangan Prototype Tampilan Halaman Edit Pegawai

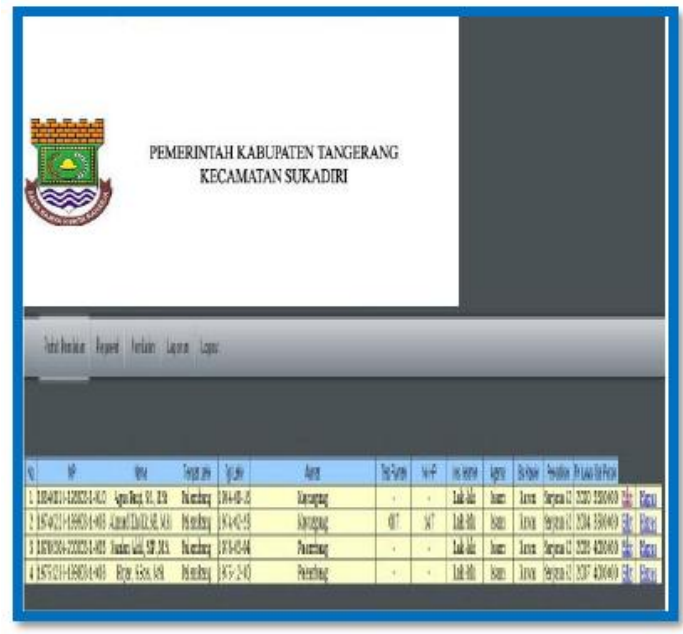

Gambar 3.10. Tampilan Halaman Edit Pegawai

4. Rancangan Prototype Tampilan Menu Laporan

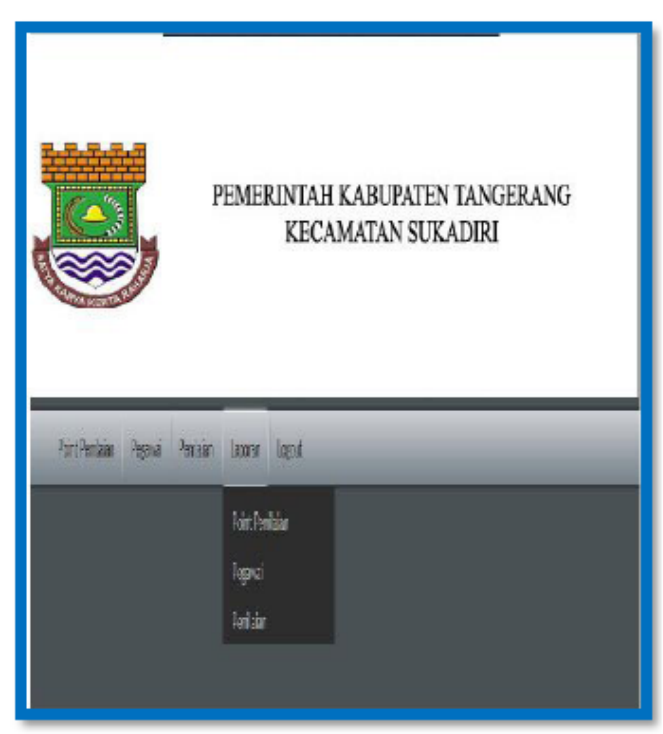

Gambar 3.11 Tampilan Menu Laporan 
5. Rancangan Prototype Tampilan Halaman Form Penilaian

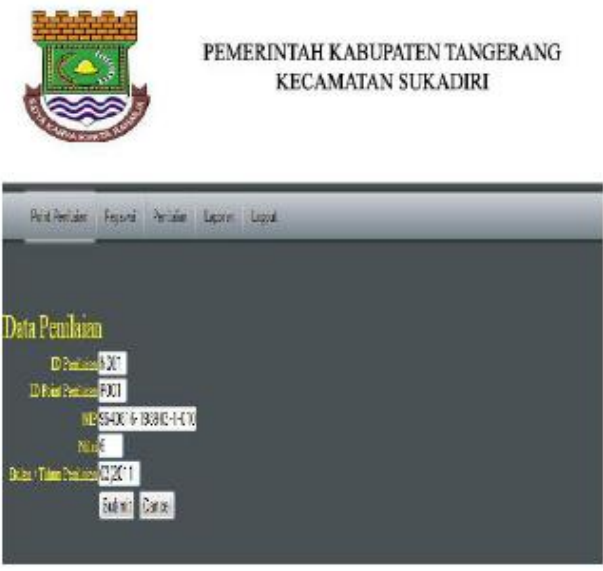

Gambar 3.12 Tampilan Halaman Form Penilain

\section{Rancangan Prototype Tampilan} Halaman Form Edit Point Penilaian

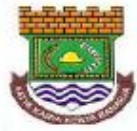

PEMERINTAH KABUPATEN TANGERANG KECAMATAN SUKADIRI

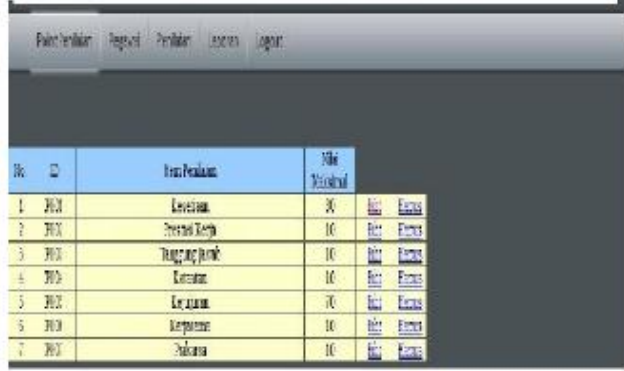

Gambar 3.13 Tampilan Halaman Form Edit Point Penilain
7. Rancangan Prototype Tampilan Halaman Laporan Pegawai
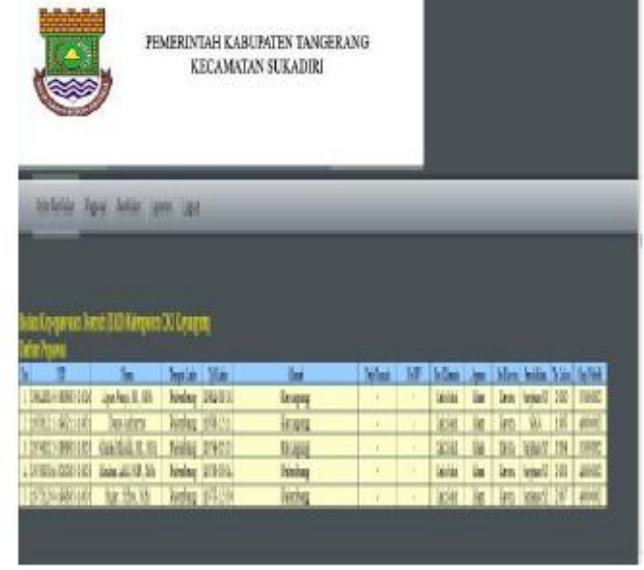

Gambar 3.14 Tampilan Tampilan Halaman Laporan Pegawai

8. Rancangan Prototype Tampilan Halaman Laporan Penilaian

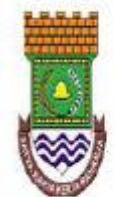

FEVRNTHHABDRADTANCERAYG KECALAZNSWRDR

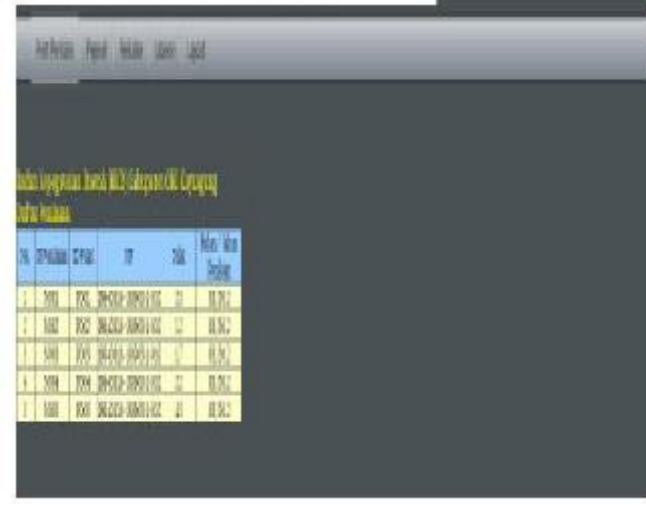

Gambar 3.15 Tampilan Halaman Laporan Penilaian 
9. Rancangan Prototype Tampilan Halaman Laporan Point Penilaian Laporan Point Penilaian

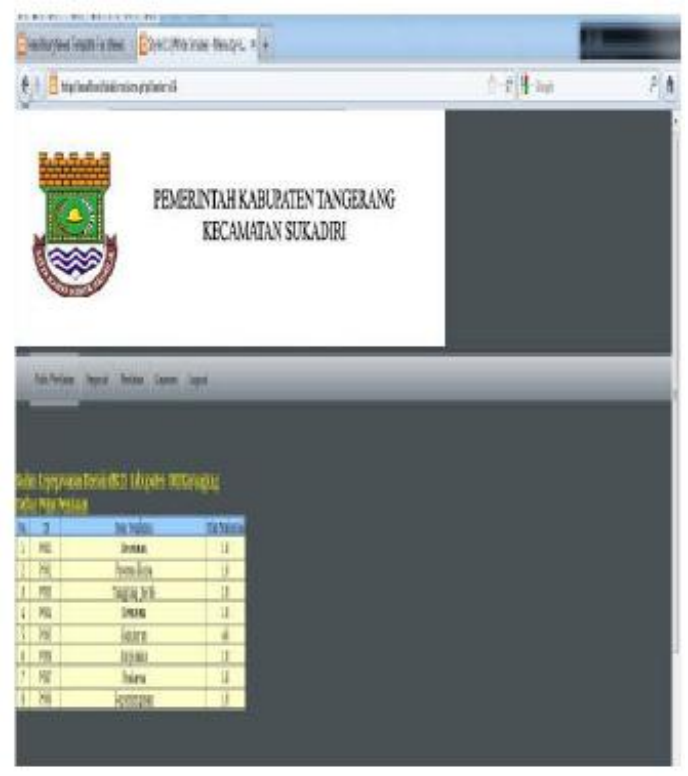

Gambar 3.16 Tampilan Tampilan Halaman

\section{KESIMPULAN}

Tahapan-tahapan dalam penelitian Kuliah Kerja Praktek ini sudah dilakukan, mulai dari observasi, studi kelayakan sampai dengan kajian terhadap kondisi sistem berjalan. Berdasarkan hal tersebut dapat disimpulkan beberapa hal diantaranya :

1. Dapat memudahkan bagian kepegawaian dalam pendataan penilaian kinerja pegawai pada Kantor Kecamatan Sukadiri Kabupaten Tangerang. Dengan adanya Sistem Penilaian Kinerja Pegawai Aparatur Pemerintahan ini menambah wawasan penulis, khususnya tentang pemrograman web PHP dan MySQL.

2. Pada sistem yang berjalan saat ini sudah memiliki pengarsipan yang rapi, prosedur sistem informasi data kepegawaian yang sistematis, akan tetapi masih memiliki kekurangan atau kendala yaitu belum mampu menyediakan informasi yang dibutuhkan secara cepat dan akurat karena belum adanya sarana dan prasarana yang mendukung dengan sistem yang dapat diakses secara online sehingga belum mampu menghasilkan laporan yang dibutuhkan dalam waktu yang singkat. Oleh sebab itu dibutuhkan sistem yang lebih baik yang memiliki akses yang cepat, menyimpanan data yang baik, masih kemungkinan adanya kesalahan dalam meng-input data pegawai sehingga untuk hasil penilaiannya kurang tepat dan akurat.

Untuk mengetahui apakah dengan menggunakan program php Penilaian Kinerja Pegawai Kantor Kecamatan Sukadiri Kabupaten Tangerang bisa membuat sistem sebelumnya menjadi efektif dan efisien.

\section{DAFTAR PUSTAKA}

Anhar. 2010. "Panduan Menguasai PHP dan MySQL Secara Otodidak”. Cet. 1. Jakarta: Media Kita

Alexander F. K. Sibero. 2011. "Kitab Suci Web Programing" . Jakarta: Mediakom

Budiawan. 2008. Perancangan Sistem Informasi Hasil Penelitian Dosen Berbasis Web Pada Perguruan tinggi Raharja. Tangerang: STMIK Raharja.

Guritno, Suryo., Sudaryono, Untung Rahardja, 2010. "Theory and Application of IT Research". CV Andi Offset. Yogyakarta.

Hernita, 2010. Membangun Website Tanpa Modal. Yogyakarta : Andi Offset

Hidayat, Rahmat, 2010. Cara Praktis Membangun Website Gratis. Jakarta : Elex Media Komputindo

Heriawati, Prabowo Pudjo Widodo. 2011. Menggunakan UML. Bandung: Informatika. 
Helmi kurniawan, iwan fitrianto rahmad. (2012). Perancangan sistem pakar untuk mendeteksi penyakit pada tanaman cabe dengan metode certainty factor. Vol 5(2), Hal 193. Jurnal CCIT. Tangerang Perguruan Tinggi Raharja.

Kadir, Abdul. 2008. "Latihan Membuat Aplikasi Web PHP dan MySQL dengan Dreamweaver MX (6,7,2004, dan 8)". Edisi Pertama. Yogyakarta : Gava Media.

Kristanto, Andi. 2008. "Perancangan Sistem Informasi dan Aplikasinya". Edisi Revisi. Cet.1. Yogyakarta : Gava Media.

Mustakini, Hartono Jogiyanto. 2008. "Metodologi Penelitian Sistem Informasi". CV Andi Offset. Yogyakarta.

Mustakini, Hartono Jogiyanto. 2009. "Sistem Teknologi Informasi". CV Andi Offset. Yogyakarta.

Mulyanto, Agus. 2009. "Sistem Informasi Konsep \& Aplikasi". Yogyakarta: Pustaka Pelajar.

McLeod, Raymond, Jr dan George P. Schell. 2008. Sistem informasi manajement. Jakarta: salemba empat

Martono aris, padeli, dina fitria murad. (2009). pengembangan sistem database penempatan tenaga kerja berbasis web. Vol 2(3), Hal 307. Jurnal CCIT. Tangerang Perguruan Tinggi Raharja.

Nugroho, Bunafit. 2008. Panduan Lengkap Menguasai Perintah SQL. Jakarta: Mediakita.

Nugroho, Adi. 2008. "Rational Rose untuk Pemodelan Berorientasi Objek". Informatika. Bandung.

Nugroho, Adi. 2010. Rekayasa Perangkat Lunak
Berorientasi Objek dengan Metode USDP. Yogyakarta: Penerbit Andi.

Nugroho, Adi. 2009. Rekayasa Perangkat Lunak Menggunakan UML dan Java. Yogyakarta: Penerbit Andi.

Oktaviani, Diar Puji. 2010. Menjadi Programmer Jempolan Menggunakan PHP. Yogyakarta: Mediakom.

Padeli, Henderi, suyatno. (2008). Membangun (E-procurement)pengadaan barang dan jasa dengan prinsip good corporate dengan visual uml. Jurnal CCIT Vol 2(1), Tangerang Perguruan Tinggi Raharja.

Henderi, S. Kom. . 2007. Unified Modelling Language, Tangerang : Raharja Enrichment Centre (REC).

Raharjo, Budi. 2011. Belajar Otodidak Membuat Database Menggunakan MySQL. Bandung: Informatika.

Sutabri, Tata. 2009. "Sistem Informasi Manajemen". Yogyakarta : Andi.

Sutisna, Dadan. 2008. 7 langkah mudah menjadi webmaster. Jakarta : Mediakita

Sigit, Christianus. 2010. Adobe Dreamwever CS 5. Edisi 1. Yogyakarta: Andi Offset.

Widodo, Prabowo Pudjo. 2011 “Menggunakan UML", Informatika. Bandung.

Wahyono Teguh. 2010. Membuat Sendiri Aplikasi dengan Memanfaatkan

Barcode. Jakarta : Elex Media Komputindo.

Drs. H. Malayu S.P. Hasibuan, 2011, "Manajemen Sumber Daya Manusia", Jakarta, PT. Bumi Aksara

Jogiyanto, Hartono 2005. "Analisa dan Design Sistem Informasi". Yogyakarta : Grafindo Persada 


\section{Petunjuk Penulisan Naskah \\ Jurnal Teknik}

1. Naskah diketik rapi satu spasi dengan menggunakan Ms. Word dengan font Time News Roman 10 pt, jumlah kata minimal 250 kata atau 8 s.d 20 halaman kertas kwarto (sudah termasuk gambar, tabel, ilustrasi dan daftar pustaka). Ukuran atau batas pengetikan margin kiri $3 \mathrm{~cm}$, margin kanan $2.5 \mathrm{~cm}$, margin atas dan bawah $3 \mathrm{~cm}$;

2. Naskah harus asli dan belum pernah dipublikasikan melalui media lain dengan menggunakan bahasa Indonesia yang baku;

3. Tulisan dapat berupa hasil penelitian, studi pustaka maupun hasil pemikiran ilmiah yang bersifat objektif, analisis dan deskriptif;

4. Sistematika penulisan disesuaikan dengan bidang ilmu masing-masing yang secara garis besar memuat:

a. Judul;

b. Nama Penulis (tanpa gelar akademik);

c. Abstrak;

d. Kata Kunci/Keywords;

e. Pendahuluan (tanpa sub judul, memuat latar belakang masalah, tinjauan pustaka, masalah/tujuan penelitian);

f. Metodologi;

g. Hasil dan Pembahasan;

h. Kesimpulan dan Saran; dan

i. Daftar Pustaka (berisi pustaka yang dirujuk dalam uraian).

5. Isi tulisan bukan tanggung jawab redaksi, redaksi berhak mengedit redaksional tanpa mengubah esensi isi;

6. Redaksi berhak menolak naskah yang tidak memenuhi syarat dan dikembalikan kepada penulis; dan

7. Naskah dikirim ke Redaksi JURNAL TEKNIK berupa CD (softcover) dan print out (naskah yang telah di print) ke alamat:

REDAKSI JURNAL TEKNIK

Fakultas Teknik Universitas Muhammadiyah Tangerang

Jl. Perintis Kemerdekaan I/33, Cikokol Kota Tangerang

TIp. (021) 51374916 